

\section{BETWEEN JEWS AND HERETICS}

"This may be the most important book on Justin Martyr's work in a century, solving major problems with understanding the text that have been unsolved since Harnack.”

-Daniel Boyarin, University of California Berkeley, USA

Justin Martyr's Dialogue with Trypho is the oldest preserved literary dialogue between a Jew and a Christian and a key text for understanding the development of early Judaism and Christianity. In Between Jews and Heretics, Matthijs den Dulk argues that whereas scholarship has routinely cast this important text in terms of "Christianity vs. Judaism," its rhetorical aims and discursive strategies are considerably more complex, because Justin is advocating his particular form of Christianity in constant negotiation with rival forms of Christianity. The striking new interpretation proposed in this study explains many of the Dialogue's puzzling features and sheds new light on key passages. Because the Dialogue is a critical document for the early history of Jews and Christians, this book contributes to a range of important questions, including the emergence of the notion of heresy and the "parting of the ways" between Jews and Christians.

Matthijs den Dulk is Assistant Professor in the Faculty of Philosophy, Theology, and Religious Studies at Radboud University, The Netherlands. 


\section{ROUTLEDGE STUDIES IN THE EARLY CHRISTIAN WORLD}

Routledge Studies in the Early Christian World offers monographs and edited collections which explore the most cutting-edge research in Early Christianity. Covering all aspects of world of early Christianity, from theology, archaeology and history, to urbanism, class, economics, and sexuality and gender, the series aims to situate these early Christians within the wider context of Late Antiquity.

Comprising both regional studies and broader thematic surveys, this series explores what changed with the advent of Christianity, what remained the same, and how early Christians interacted with, made sense of, and shaped the world around them. Aimed at early Christian scholars, classicists and historians alike, Studies in the Early Christian World is an invaluable resource for anyone researching this fascinating period.

RECONCEIVING RELIGIOUS CONFLICT

New Views from the Formative Centuries of Christianity

Edited by Wendy Mayer and Chris L. de Wet

JEWISH GLASS AND CHRISTIAN STONE

A Materialist Mapping of the 'Parting of the Ways'

Eric C. Smith

THE SLAVE METAPHOR AND GENDERED ENSLAVEMENT

IN EARLY CHRISTIAN DISCOURSE

Double Trouble Embodied

Marianne Bjelland Kartzow

BETWEEN JEWS AND HERETICS

Refiguring Justin Martyr's Dialogue with Trypho

Matthijs den Dulk

For more information on this series, visit: https://www.routledge.com/RoutledgeStudies-in-the-Early-Christian-World/book-series/SECW 


\title{
BETWEEN JEWS AND HERETICS
}

\author{
Refiguring Justin Martyr's \\ Dialogue with Trypho
}

Matthijs den Dulk

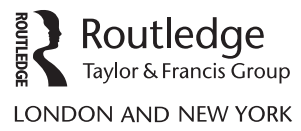


First published 2018

by Routledge

2 Park Square, Milton Park, Abingdon, Oxon OX14 4RN

and by Routledge

711 Third Avenue, New York, NY 10017

Routledge is an imprint of the Taylor \& Francis Group, an informa business

(C) 2018 Matthijs den Dulk

The right of Matthijs den Dulk to be identified as author of this work has been asserted by him in accordance with sections 77 and 78 of the Copyright, Designs and Patents Act 1988.

All rights reserved. No part of this book may be reprinted or reproduced or utilised in any form or by any electronic, mechanical, or other means, now known or hereafter invented, including photocopying and recording, or in any information storage or retrieval system, without permission in writing from the publishers.

Trademark notice: Product or corporate names may be trademarks or registered trademarks, and are used only for identification and explanation without intent to infringe.

British Library Cataloguing-in-Publication Data

A catalogue record for this book is available from the British Library

Library of Congress Cataloging-in-Publication Data

A catalog record for this book has been requested

ISBN: 978-0-815-37345-2 (hbk)

ISBN: 978-1-351-24349-0 (ebk)

Typeset in Times New Roman

by Apex CoVantage, LLC 


\section{CONTENTS}

List of abbreviations

vi

Acknowledgments

viii

Introduction

1 Justin Martyr, heresy hunter 13

2 The case for an internal audience 38

3 The Dialogue as an anti-heretical text 52

4 "Heresy" and the composition of the Dialogue 69

5 In favor of heresiology 95

$\begin{array}{ll}\text { Conclusion } & 139\end{array}$

Appendix: Justin Martyr and Acts of the Apostles 145

Bibliography $\quad 155$

Index 169 


\title{
ABBREVIATIONS
}

\author{
AB Anchor Bible \\ AJS American Journal of Sociology \\ ANRW Aufstieg und Niedergang der römischen Welt \\ BHTh Beiträge zur historischen Theologie \\ BZ Biblische Zeitschrift \\ BZNW Beihefte zur ZNW \\ CBET Contributions to Biblical Exegesis \& Theology \\ CQ Classical Quarterly \\ CRINT Compendia Rerum Iudaicarum ad Novum Testamentum \\ CSCO Corpus Scriptorum Christianorum Orientalium \\ EC Early Christianity \\ GCS Die griechischen christlichen Schriftsteller der ersten Jahrhunderte \\ HR History of Religions \\ HTR Harvard Theological Review \\ HUCA Hebrew Union College Annual \\ HUTh Hermeneutische Untersuchungen zur Theologie \\ ICC International Critical Commentary \\ JBL Journal of Biblical Literature \\ JCP Jewish and Christian Perspectives \\ JECS Journal of Early Christian Studies \\ JEH Journal of Ecclesiastical History \\ JQR Jewish Quarterly Review \\ JR Journal of Religion \\ JRS Journal of Roman Studies \\ JSJ Journal for the Study of Judaism \\ JSNT Journal for the Study of the New Testament \\ JTS Journal of Theological Studies \\ LNTS Library of New Testament Studies \\ NICNT New International Commentary on the New Testament \\ NovT Novum Testamentum \\ NTS New Testament Studies \\ PTS Patristische Texte und Studien
}


RAC Reallexikon für Antike und Christentum

SA Sociological Analysis

SC Sources chrétiennes

SJT Scottish Journal of Theology

SNTSMS Society for New Testament Studies Monograph Series

SVF Stoicorum veterum fragmenta

TBN Themes in Biblical Narrative

TDNT Theological Dictionary of the New Testament

TSAJ Texts and Studies in Ancient Judaism

TU Texte und Untersuchungen zur Geschichte der altchristlichen Literatur

USQR Union Seminary Quarterly Review

VC Vigiliae Christianae

VT Vetus Testamentum

WBC Word Biblical Commentary

WUNT Wissenschaftliche Untersuchungen zum Neuen Testament

ZAC Zeitschrift für Antikes Christentum / Journal of Ancient Christianity

ZKG Zeitschrift für Kirchengeschichte

ZNW Zeitschrift für die Neutestamentliche Wissenschaft und die Kunde der älteren Kirche 


\section{ACKNOWLEDGMENTS}

I have incurred a great number of debts in the process of writing this book. First of all, many thanks are due to Margaret Mitchell, who was my advisor and chair of the committee that accepted an earlier, rather different version of this study as a doctoral dissertation at the University of Chicago in 2015. If this monograph exhibits any scholarly virtues at all, it is largely to her credit. She has consistently been a model of scholarly excellence and a great supporter as well extremely perceptive critic of my work. I am deeply grateful for her example and guidance.

Many others have also been sources of academic and moral support. I fondly remember the camaraderie and helpful conversations I enjoyed during my time at Chicago. In particular, I would like to mention Jonathan Soyars and Andrew Langford, who not only shared the joys and burdens of the doctoral experience at Chicago with me but also read and commented on this manuscript in its entirety, and to great avail. Others who have offered helpful criticism and suggestions include Daniel Boyarin, David Brakke, Brandon Cline, Michael Fishbane, Allison Gray, Galit Hasan-Rokem, and Hans-Josef Klauck. I am very grateful to all of them for their invaluable advice. Their rigorous critique and collegial encouragement has meant a great deal to me.

I am pleased also to acknowledge the financial support provided by the University of Chicago and the Martin Marty Center for the Advanced Study of Religion, as well as the generosity of my colleagues at Radboud, who provided me with a new intellectual home. I would also like to thank the excellent team at Routledge for their enthusiasm, professionalism, and expertise.

Most of all, I am profoundly grateful to Yael for her unfailing encouragement and willingness to move across the Atlantic with me not once but twice (and the second time with a kid in tow, no less). I am under no illusion that I can ever repay her for her kindness, love, and generosity of spirit. Dankjewel, liefste. Dit alles is dankzij jou. 


\section{INTRODUCTION}

Aristotle once remarked that "one sees matters most clearly if one studies them in the process of development from the beginning" (Pol. I.2, 1252a24). ${ }^{1}$ The implication of Aristotle's statement for the study of Christianity would seem straightforward: in order to understand it accurately, one should start by scrutinizing its beginning. But determining Christianity's originary moment has turned out to be challenging. Arguably the most important complicating factor is that it is difficult to identify when Christianity became something other than Judaism. ${ }^{2}$ Whereas earlier scholarship tended to think in terms of a clear break or "parting of the ways" between Judaism and Christianity that could be relatively securely dated sometime between Jesus's ministry and the immediate aftermath of the destruction of the second temple in $70 \mathrm{CE}$, more recent work has recast this process as a complex, lengthy, messy, and ultimately not even fully resolved separation. ${ }^{3}$ Christian identity vis-à-vis Judaism remained inchoate and in flux for a long time, certainly well into the second century CE.

The prolonged nature of the process is evident also with respect to another crucial aspect of the formation of early Christianity. In addition to eventually partitioning itself off from Judaism, Christianity's formation also involved establishing a certain degree of internal coherence. Today, most scholars recognize that there was substantial diversity among followers of Jesus from the outset rather than an original unity. ${ }^{4}$ It would take considerable time for a single, reasonably coherent group to emerge from an originally diverse range of "Christ-faiths." Prior to this moment, which is likewise difficult to date, but certainly cannot be located earlier than the second century CE, there was arguably no such thing as a single Christianity. There were, at best, only "Christianities."

What makes Justin Martyr's Dialogue with Trypho such a compelling text is that it is among our most important sources for both of these crucial developments (separation from Judaism and the production of a single, relatively unified form of Christianity). The Dialogue, composed sometime between 160 and $165 \mathrm{CE}$, is the oldest preserved literary dialogue between a Jew (Trypho) and a Christian (Justin). ${ }^{5}$ Written by Justin Martyr, a self-styled philosopher from Flavia Neapolis (present-day Nablus), the Dialogue tells us a great deal about contemporary "Christianities" and (other) Judaism(s), and is, therefore, among the most 
important documents for scholarly reconstruction of the relationship between Jews and Christians in antiquity, and, by extension, of the emergence of Judaism and Christianity as two separate religious and cultural systems.

The Dialogue is also a crucially important text for the process of creating a unified Christian identity. Key to this development was the invention and implementation of the orthodoxy-heresy binary. This discursively facilitated the denial of legitimacy to "other" Jesus-believers while presenting one's own community as the single true way of following Jesus, thus bringing about, at least rhetorically, the kind of relative unity characteristic of Christianity beyond late antiquity. In his influential monograph La notion d'hérésie dans la littérature grecque, Alain Le Boulluec identified Justin as the inventor of "heresy." This now classic view has increasingly come under criticism, but it remains true that Justin is a very important source for the "history of heresy," because in his work a number of elements that would become characteristic of the long tradition of Christian heresiological discourse can first be identified. ${ }^{7}$ The Dialogue occupies center stage in this connection, because whereas

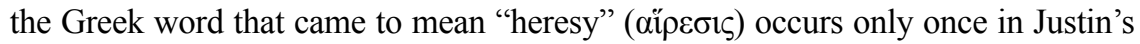
earlier First Apology and not at all in his Second Apology, it appears no fewer than six times in the Dialogue $\left(17.1 ; 35.3 ; 51.2{ }^{8} 62.3 ; 80.4 ; 108.2\right)$, in addition to the

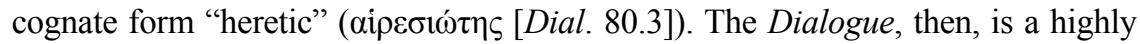
significant document for the development of Christianity as an entity both separate from Judaism and limited in terms of internal diversity.

Despite its significance, the Dialogue has received limited sustained scholarly attention in recent decades. ${ }^{9}$ The fact that not all that much study has been devoted to it over the past thirty years since the publication of Oskar Skarsaune's very important monograph The Proof from Prophecy perhaps has to do in part with its length..$^{10}$ The Dialogue is long, very long; it is by far the longest surviving text from the first one hundred and fifty years of the Jesus-movement. ${ }^{11}$ In its current form, it is longer than the gospels of Matthew, Mark, and Luke combined, but originally it was even more sizeable. ${ }^{12}$ The Dialogue is also a convoluted, unwieldy text. It lacks clear structural markers, and its argument is not always easy to follow. ${ }^{13}$ None of these phenomena justifies the comparative lack of scholarly attention, of course. The Dialogue contributes significantly to the areas of scholarly focus discussed above and therefore analysis of it is essential to understanding the early development of Christianity. In this study, I propose a fresh interpretation of the text that sheds new light on what the Dialogue is about and, in so doing, seeks to contribute to some of the larger questions raised above about the formation of early Christianity.

\section{Refiguring the Dialogue}

Traditionally, the Dialogue has been read as an extended argument for the superiority of "Christianity" over against "Judaism," preceded by a somewhat oddly connected preamble about the preeminence of "Christianity" relative to GrecoRoman philosophical schools (Dial. 1-9). Scholars have long been divided over 
whether this defense was primarily intended for a Jewish, "pagan" or Christian audience. ${ }^{14}$ And yet, despite their disagreement, they assume the Dialogue should be read in terms of "Christianity vs. Judaism." For example, Tessa Rajak claims with reference to the core concern of the Dialogue: "The justification of Christianity rested in the promises of the Old Testament, correctly interpreted; but these interpretations were always open to Jewish challenge, striking at the essence of Christian identity." ${ }^{15}$ But can we really speak of the essence of Christian identity at this point in time? Justin himself clearly demonstrates that many in his own day differed in their understanding of Christian identity (as will become abundantly clear over the course of this study). For some, the essence of Christian identity would have had nothing to do with the Old Testament: indeed, it might even require the active rejection of Old Testament writings. This is not a minor terminological quibble. The robustness with which "Christianity" is posited in much Justin scholarship obscures a variety and diversity that is key to understanding the work that the Dialogue is doing. The traditional reading of the Dialogue in terms of Christianity vs. Judaism fails to recognize and account for the fact that there was no such thing as a singular Christianity in Justin's day. There were, rather, several radically different interpretations of what being Christian entailed. Constantly present when Justin positions himself over against Jewish and GrecoRoman philosophical traditions, therefore, is a debate with other Christianities that staked out competing positions.

In the Dialogue Justin is arguing his own perspective over and against Christian alternatives. This is an essential dimension of the Dialogue, and overlooking it impoverishes and even skews any potential reading of it. Justin's presentation of Greco-Roman philosophy and Judaism is animated in important ways by his attempts to demonstrate the superiority of his understanding of Christianity over other Christianities. This effort influenced the way that he develops the conversation with Trypho, and it helped shape the literary setting of the Dialogue, as well as the topics that are discussed, the interpretations offered, and the arguments made. I propose, in sum, that we must recalibrate our reading of the Dialogue by taking into account its historical embeddedness within a fluid and still emerging sense of Christian identity.

I suggest that we begin developing this new perspective on the text by looking at some of the remarkable features of the Dialogue. I have already noted its problematic structure and its extraordinary length. The latter is due in part to what appear to be unnecessarily long quotes from the Septuagint. In some cases, exasperated scribes appear to have shortened what were originally longer quotes still; this can be detected when Justin refers back to something that he has already quoted but our text contains only part of the quoted passage, not the part that Justin had in mind. ${ }^{16}$ This is connected to another curious characteristic of the Dialogue - its high degree of repetition. It purportedly records two days of discussions, and some of its repetitions are meant to bring new attendees up to speed. But why did Justin include so much repetition rather than simply list the topics that were discussed again $?^{17}$ The content of the document raises even more questions. The Dialogue 
presents itself as the record of an attempt to persuade a group of Jewish interlocutors ${ }^{18}$ of the truth of Christianity. ${ }^{19}$ But it contains such harsh and bitter polemic against the Jews that it is difficult to see how the author could have believed that he was doing a very good job of winning them over. Indeed, despite Justin's stated evangelistic intentions, the Dialogue ends surprisingly with neither Trypho nor any of his companions being persuaded after two full days of discussion. ${ }^{20}$

To sum up, the Dialogue is a curious document, full of puzzles that invite investigation. One way that scholars have sought to make sense of the Dialogue is to remove some of what does not make sense and assign it to a later redactor or to posit that its author drew from an originally well-ordered, coherent text and that the Dialogue was put together in an indiscriminate and haphazard way. ${ }^{21}$ While not denying the reasonable, yet largely unverifiable, possibility of secondary accretions and redactional and scribal alterations, I propose that we try to explain the document in the form found in our manuscript. ${ }^{22}$ Any theory that posits that the Dialogue is essentially nonsensical and explains its present form as the result of careless editorial choices should only be a last resort.

Much about the Dialogue can be explained, I suggest, if we take seriously Justin's intellectual and ecclesiastical context in the mid-second century. This context was, as noted above, characterized by considerable diversity. It was a period of transition and negotiation, one in which clear boundaries between and among different kinds of Jews and Christians can sometimes be detected on the rhetorical level but rarely "on the ground." Justin's work must be situated in this world where Christian and Jewish identities were still very much in flux and negotiable. Among Jesus-followers, there was a great variety of groups claiming the name "Christian," all existing alongside each other apparently without a great deal of overt conflict, at least in Rome (see discussion on pp. 118-119). ${ }^{23}$

For Justin, this degree of diversity was unacceptable. I will argue that there was one intellectual current in particular that he considered entirely beyond the pale, the "Christian demiurgists." The label is mine, not Justin's. I use it and related phrases, such as "demiurgical Christians," to refer to those early Jesus-followers who posited a Demiurge separate from the First or Supreme Being. ${ }^{24}$ They did not consider the God of the Jewish Scriptures to be identical with the Father of Jesus and did not regard the Jewish Scriptures as divinely inspired (at least not in any straightforward or comprehensive sense). To them, the Jewish God was but a "Demiurge," a "craftsman" responsible for creation, in part or in whole, but not the highest God. Indeed, they viewed the Demiurge and the highest God as to some degree at odds with one another. Marcion is arguably the most prominent representative of this school of thought but he was by no means the only Christian demiurgist. Justin mentions by name not only the Marcionites but also the Valentinians, Basilidians and Saturnilians, who, in his view, "blaspheme the Creator of the universe" (Dial. 35.5). He likely knew of others who espoused demiurgical forms of Christianity as well. ${ }^{25}$

In Chapter 1, I argue that Justin had been long engaged in attacking these kinds of Christians by the time he wrote the Dialogue. Evidence for this claim comes 
primarily from the one major treatise from earlier in Justin's career, the First Apology (c. $150 \mathrm{CE}$ ) ${ }^{26}{ }^{2}$ This document is often regarded as an attempt to end the prosecution of the Christians. ${ }^{27}$ In fact, however, Justin only seeks reprieve for his kind of Christians. At the same time, Justin actively seeks to undercut the judicial position of some of his Christian rivals, going so far as to effectively advocate their prosecution. What these rivals had in common, I argue, was their adherence to demiurgical notions. These same Christians also bore the brunt of Justin's attacks in a lost treatise "against the heresies" mentioned in 1 Apol. 26, which is often referred to as the Syntagma. ${ }^{28}$ While there is not much that we can know about this lost treatise with certainty, we can reasonably surmise that the groups targeted by Justin were all Christian demiurgists.

I propose that Justin continues these anti-demiurgical efforts in the Dialogue. Before developing this argument, however, we will need to address the muchcontested question of the Dialogue's audience. Chapter 2 argues that the Dialogue was written initially and primarily for an internal audience: for Justin's own social circle, which consisted primarily, though not necessarily exclusively, of likeminded Christians. The chapter advances a number of fresh arguments in support of this view both on the basis of clues within the text as well as consideration of the practical realities of book production and distribution in the Roman world.

Building on the results of these two introductory chapters, Chapter 3 argues that an important task of the Dialogue was to convince this internal audience of the inadequacy of demiurgical forms of Christianity, thus continuing the anti-heretical battle waged in both the Syntagma (the lost treatise) and the First Apology. The arguments that Justin offers in the Dialogue can be read in two ways. For instance, Justin's claim that Jesus is the Messiah promised in the Jewish Scriptures can be read as an argument to non-Jesus-believing Jews that Jesus is the one foretold in the Jewish Scriptures. But it can also be read as an argument to those who believe in Jesus that the Jewish Scriptures prophesied about him and must therefore be accepted as a central part of Christian teaching and identity. Given Justin's focus on attacking demiurgical Christians in his previous literary works and the likelihood that he wrote for an internal audience still very much faced with the intellectual challenges posed by these demiurgists, I suggest that the latter possibility must be taken very seriously. In fact, virtually every topic in the Dialogue, ranging from the question of the Old and the New Law to the consistency of God, the New and the Old Israel, and so on, is immediately pertinent to the contest between Justin's kind of Christianity and those of his demiurgical rivals. This is confirmed by the fact that Tertullian and Irenaeus discuss many of the same topics in their treatises against Marcion and other Christian demiurgists.

The likelihood that Justin has his eyes trained on these Christian opponents is further strengthened by a substantial number of moments in the Dialogue in which Justin responds in a way or to an issue that is relevant to his internal debate with the demiurgists, more than to his conversation with Trypho (and Jews more generally). To the extent that these passages have been recognized in previous scholarship, they have been routinely dismissed as inadvertent "remains" or "echoes" 
of Justin's earlier contestation with the "heretics" in the Syntagma. I argue, by contrast, that these are moments where the anti-heretical force of the Dialogue as a whole comes more clearly to the fore. They are not the results of careless writing (or editing) on Justin's part.

This conclusion raises an important question: Why did Justin choose the literary format of a dialogue between a Christian and a Jew? Is all of this but an elaborate fiction to address internal debates? Is Trypho nothing but a "rhetorical Jew"? Some scholars have argued, albeit in the service of a very different argument, that the Jewish-Christian conversation captured in the Dialogue is indeed little more than a rhetorical ploy. ${ }^{29}$ The alternative view maintains that the Dialogue really was written to reach a Jewish audience and that the passages that seem to address internal challenges are therefore out of place.

In Chapter 4, I suggest that it is possible to chart a way between these two alternatives by considering the role that the effort to convert ${ }^{30}$ Jews played in the debate between demiurgical and non-demiurgical Christians. A central point of contention between these different kinds of Christians was the question of whether the Jewish Scriptures refer to Jesus. Justin's demiurgical opponents denied any connection between the Jewish God and Jesus and hence dismissed the view that the Scriptures of the Jewish God had foretold Jesus's life and death. In this debate, Justin's rivals could cite the lack of Jewish converts in support of their position. What better argument could one lodge against the claim that Jesus was in view in those Jewish writings than the simple observation that the great majority of Jews did not recognize Jesus as the promised Messiah? As we will see, Tertullian confirms that this was a powerful argument presented by demiurgical Christians against the position of Justin and Christians like him. Seen in this light, the efforts to convert Jews and to combat "heretics" are not incompatible, but intimately related. If one could persuade a Jewish audience that Jesus is the one mentioned in their Scriptures, this would refute the demiurgists, who cited Jewish unbelief in support of their own theological position. On this interpretation, then, Justin was genuinely interested in reaching a non-Jesus-believing Jewish audience (indirectly, via his internal audience), but this is closely related to his efforts to undercut the position of his "heretical" opponents.

The argument developed here should accordingly not be misconstrued as a reduction of the Dialogue to little more than an anti-heretical treatise. Justin really is deeply interested in persuading a non-Jesus-believing Jewish audience of the truth of his Christian message, and his work was potentially of interest to other parties as well. I argue however that combatting demiurgical tendencies and promoting a heresiological response to the demiurgists is likewise an important aspect of the work that the Dialogue was meant to do. In addition to offering a mediating position between the two extremes outlined above (Justin is entirely uninterested in converting Jews or his anti-heretical efforts are completely out of place), I will argue that this reading can also elucidate various puzzling aspects of the Dialogue, such as its surprising ending, its odd juxtaposition of evangelistic overtures and harsh vituperations, and Trypho's remarkable agreement with much 
of what Justin has to say. Furthermore, the literary mis-en-scène of the Dialogue shortly after the Bar Kochba revolt (132-135 CE), as well as the introductory chapters on Greco-Roman philosophy that appear to have little to do with the remainder of the text, can also be explained more fully by situating the Dialogue in a context of internal Christian debate and conflict. That so many otherwise curious features can be explained in this way speaks strongly in favor of such a contextualization.

In the fifth and final chapter, I turn to the passages in the Dialogue where Justin expressly mentions his "heretical" opponents. Here the Dialogue's interest in "heresy" has not escaped previous scholarship. Since Justin is regarded by many as the "inventor of heresy" (or at least as an important early contributor to the development of the notion of heresy), these passages have long been recognized for their significance. However, they have usually been considered in isolation from the rest of the Dialogue by scholars working on early Christian heresiology. Scholars who focused on the Dialogue itself rather than on Justin's contribution to the history of heresy have similarly tended to treat these sections as interludes or digressions essentially unrelated to Justin's overall argument about the relationship between Judaism and Christianity. In my view, these passages are instead explicit statements of the anti-heretical argument Justin advances throughout the Dialogue. The people he singles out as "heretics" are those who "blaspheme the God of Abraham, Isaac and Jacob" - in other words, demiurgists. These passages confirm that demiurgical Christianity was firmly on Justin's mind when he composed the Dialogue. By situating his comments on heresy in the context of the broader literary argument in both the Dialogue (in this chapter) and in $1 \mathrm{Apol}$. (in Chapter 1), this study seeks to contribute to the scholarly understanding of the development of early Christian heresiology, as well as to the interpretation of Justin.

This chapter argues, in addition, that the passages in which Justin expressly refers to his opponents as belonging to haireseis are not simply moments where Justin labels these people "heretics" (and implicitly seeks to persuade his internal audience to do the same), because this would assume that the notion and "technology" of heresy were already widely accepted and adopted. His discourse at this point is, instead, as much an argument in favor of the heresiological approach itself as it is an appeal to regard certain groups as heretical. Justin is writing in a context in which his hardline heresiological approach was not yet generally accepted. Working against this background, Justin sought to demonstrate that heresiology (understood here as a discourse rather than a literary genre) had clear advantages and could serve to strengthen the Christian evangelistic and apologetic appeal. The obvious downside of heresiology was that it drew attention to division and dissent among self-proclaimed Christians. Such disunity carried many negative associations in the Greco-Roman world. To undercut these potential problems (and objections to the adoption of heresiology on this basis), Justin developed various strategies in the Dialogue. He argued that the presence of heresies among the Christians came about in fulfillment of prophecy, and he contended that although 
Christians did suffer division, the problem was even worse among their rivals most notably in this context, the Jews. Justin insisted that they were more divided than the Christians and argued that heresy itself was both more widely spread and more deeply rooted among them. In making this argument, Justin offers an account of heresy among the Jews that is essentially, I will argue, a Christian projection. Justin's list of seven Jewish heresies in Dial. 80, for instance, seems to have been based primarily on Acts of the Apostles, rather than on any accurate knowledge about actual sectarian Jewish groups. Whether Justin was familiar with Acts, which is an important question for scholarship on both Justin and Acts, will be addressed in detail in the appendix to this study. Regardless of the degree to which Acts played a role in Justin's construal of Jewish heresy, however, the clearly apologetic function of Justin's comments on Jewish hairesis raises doubt about their historical reliability. This conclusion is of significance for scholarly reconstructions of contemporary Judaism(s), as well as the development of the notion of heresy.

On the reading proposed in this study, the Dialogue offers an argument in favor of a particular kind of Christianity to other Christians and Jews alike. This form of Christianity stands in opposition to demiurgical Christianities and demands the radical exclusion of those who advanced such ideas: they are denied their claim to Christian identity. Thus Justin advocates not just a non-demiurgical but also a heresiological form of Christianity. His positioning of his own theological position vis-à-vis the Jewish and Greco-Roman philosophical traditions is accordingly at one and the same time a negotiation with various rival views within Justin's diverse Christian world. Construed in this manner, the Dialogue emerges as a surprisingly rich and inventive text that is doing much more than offer a straightforward presentation and defense of Christianity over against Judaism. ${ }^{31}$

\section{Notes}

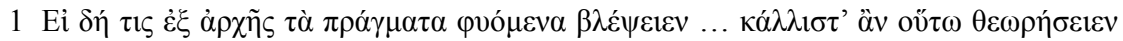
(Greek text according to William D. Ross, Aristotelis politica, Scriptorum classicorum bibliotheca Oxoniensis [Oxford: Clarendon Press, 1957]). All translations of ancient sources are my own unless otherwise noted.

2 "Judaism" is itself a complex construct that arguably only came into existence as a counterpoint to Christianity. See Daniel Boyarin, Border Lines: The Partition of JudaeoChristianity, Divinations (Philadelphia: University of Pennsylvania Press, 2004).

3 For a critique of earlier scholarship, see Paula Fredriksen, "What Parting of the Ways?," in The Ways That Never Parted: Jews and Christians in Late Antiquity and the Early Middle Ages, ed. Adam H. Becker and Annette Yoshiko Reed, TSAJ 95 (Tübingen: Mohr Siebeck, 2003), 35-63. Frederiksen's essay and the collection in which it appears argue forcefully that Jewish-Christian relations were much more complex and enduring than is often suggested. The work of Judith Lieu (esp. " 'The Parting of the Ways': Theological Construct or Historical Reality?," JSNT 17 [1994]: 101-19) provided a particularly important impetus to scholarly efforts to rethink the traditional "parting of the ways" model.

4 There has been a wave of publications on early Christian diversity in the wake of the discovery of the Nag Hammadi library in 1945 and the 1979 publication of the English 
translation of Walter Bauer, Rechtgläubigkeit und Ketzerei im ältesten Christentum, 2nd ed., BHTh 10 (Tübingen: Mohr Siebeck, 1964).

5 On the Dialogue's date, see, e.g., Timothy J. Horner, "Listening to Trypho": Justin Martyr's Dialogue Reconsidered, CBET 28 (Leuven: Peeters, 2001), 7.

6 Alain Le Boulluec, La notion d'hérésie dans la littérature grecque, IIe-IIIe siècles (Paris: Études augustiniennes, 1985), e.g., 1:110. Le Boulluec's identification of Justin as the inventor of heresy received a favorable reception. Elaine Pagels, "Irenaeus, the 'Canon of Truth,' and the 'Gospel of John': 'Making a Difference' through Hermeneutics and Ritual," VC 56 (2002): 340, refers to it as "the traditional view"; J. Rebecca Lyman, "2002 NAPS Presidential Address: Hellenism and Heresy," JECS 11 (2003): 217, calls Justin Martyr "the acknowledged early inventor of heresiology."

7 Judith M. Lieu, Marcion and the Making of a Heretic: God and Scripture in the Second Century (New York: Cambridge University Press, 2015), cautions against assigning Justin a singular position in the history of "heresy" at various points (e.g., pp. 19-20, 26-7), cf. also Judith M. Lieu, "From Us but Not of Us? Moving the Boundaries of the Community," in Early Christian Communities between Ideal and Reality, ed. Mark Grundeken and Joseph Verheyden, WUNT 342 (Tübingen: Mohr Siebeck, 2015), 164-165; Geoffrey Smith has suggested that the claim that Justin invented "heresy" must be relinquished because he argues that Justin did not compose the earliest anti-heretical treatise (Geoffrey S. Smith, Guilt by Association: Heresy Catalogues in Early Christianity [Oxford; New York: Oxford University Press, 2015], 49-86, but cf. Matthijs den Dulk, "Justin Martyr and the Authorship of the Earliest Anti-Heretical Treatise," $V C$, forthcoming); and Boyarin, Border Lines, can be read as implicitly nuancing Justin's role by construing the invention of heresy as a simultaneous and parallel development in Christian and Jewish sources (cf. also the comments by Eduard Iricinschi and Holger Zellentin discussed below, p. 117). The most significant contribution in this area, however, is Royalty, The Origin of Heresy: A History of Discourse in Second Temple Judaism and Early Christianity, Routledge Studies in Religion 18 (New York: Routledge, 2013), who identifies (aspects of) heresiological discourse in earlier texts. He does not contest, however, that Justin plays an important role in the "history of heresy" (p. 8).

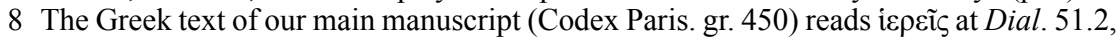

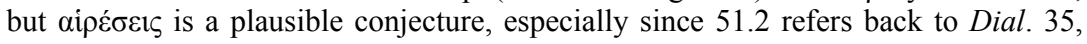

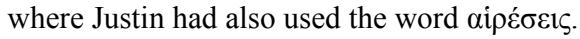

9 The most recent monograph on the Dialogue in English dates from 2002: Craig D. Allert, Revelation, Truth, Canon, and Interpretation: Studies in Justin Martyr's Dialogue with Trypho, VC Supplements 64 (Leiden; Boston: Brill, 2002). The Dialogue has not fared much better in other research languages. It has, though, been the subject of shorter treatment in recent years. Particularly salient in this connection are the important discussions in Boyarin, Border Lines as well as in Andrew Hayes, Justin against Marcion: Defining the Christian Philosophy, Emerging Scholars (Minneapolis, MN: Fortress Press, 2017). This study came to my attention very shortly before the final version of my own work was due and I have been unable to take sufficient account of it.

10 Oskar Skarsaune, The Proof from Prophecy: A Study in Justin Martyr's Proof-Text Tradition: Text-Type, Provenance, Theological Profile, NovT Supplements 56 (Leiden: Brill, 1987).

11 Horner, Listening to Trypho, 7, claims that the Dialogue "is far and away the largest document we have from the second century," while Bart D. Ehrman, Lost Christianities: The Battle for Scripture and the Faiths We Never Knew (New York: Oxford University Press, 2003), 149 makes the same claim for the Shepherd of Hermas (the discrepancy between these two claims is noted by Andrew S. Jacobs, Christ Circumcised: A Study in Early Christian History and Difference, Divinations [Philadelphia: University of Pennsylvania Press, 2012], 211 n. 22). The Dialogue is clearly longer than Hermas (52,600 
words in the Goodspeed edition of the Dialogue versus 27,368 words in Whittaker's edition of Hermas, according to TLG [almost all of Hermas 107.3-114.5 has only been preserved in Latin, but this does not significantly alter the statistics]). However, Irenaeus's Adversus Haereses (usually dated c. $180 \mathrm{CE}$ ) is considerably longer still, as can easily be observed by comparing the length of Dial. and A.H. in the classic Ante-Nicene Fathers translation: the Dial. takes up 77 pages versus $A$.H.'s 253 pages.

12 Scholars agree about the presence of a lacuna in Chapter 74, but its size is disputed. Philippe Bobichon, Justin Martyr, Dialogue avec Tryphon (Fribourg: Acad. Press, 2003), 49-72, offers an extensive discussion. There may be other lacunae as well; see Miroslav Marcovich, Dialogus cum Tryphone, PTS 47 (Berlin; New York: Walter de Gruyter, 1997), 4-6.

13 Notwithstanding Justin's occasional reference to the order of the discussion (e.g., Dial. 42.4 and related to that, his own rhetorical abilities [58.1-2]), scholarship has generally been very critical of his compositional technique. Even Bobichon, who objects to the scholarly tradition of characterizing the composition of the Dialogue as rambling and random has to admit that in the final analysis "Par sa nature même le contenu du Dialogue semble résister à toute présentation synoptique" (Bobichon, Justin Martyr, Dialogue avec Tryphon, 41). Perhaps the only relatively clear division in the entire document is the separation between Dial. 9 and 10 (although on this point too not everyone is agreed [see, e.g., Anette Rudolph, "Denn wir sind jenes Volk ..." Die neue Gottesverehrung in Justins Dialogue mit dem Juden Tryphon in historisch-theologischer Sicht, Hereditas: Studien zur Alten Kirchengeschichte (Bonn: Borengässer, 1999), 71-4]). And this division is problematic for different reasons: the two parts it creates (1-9 about philosophy and 10-142 about the relationship between Judaism and Christianity) have seemed only tenuously related to many readers (see Chapter 4).

14 On the question of audience, see Chapter 2.

15 Tessa Rajak, "Talking at Trypho: Christian Apologetic as Anti-Judaism in Justin's 'Dialogue with Trypho the Jew," in Apologetics in the Roman Empire: Pagans, Jews, and Christians, ed. Mark J. Edwards et al. (Oxford: Oxford University Press, 1999), 62.

16 Marcovich, Dialogus cum Tryphone, 4; Erwin R. Goodenough, The Theology of Justin Martyr (Jena: Frommann, 1923), 97.

17 As Justin does, by way of exception, in Dial. 128.1.

18 On the identity of Justin's interlocutors, see below pp. 47-48 n. 12.

19 It should perhaps be stressed again that "Christianity" was (and is!) not a stable concept. Moreover, "Christianity" is not a term that Justin uses (the words "Hellenism"

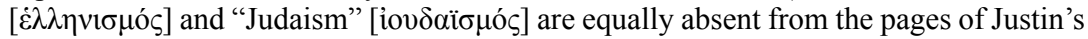
corpus). I have chosen not to repeat incessantly "as Justin understood it," but the reader should bear in mind that wherever "Christianity" and its cognates appear in this book, the label expresses a particular vantage point that was not necessarily shared by all interested parties.

20 The debate begins "early in the morning" ( $\check{\omega} \omega \varepsilon v)$ on day one (Dial. 1.1) and keeps

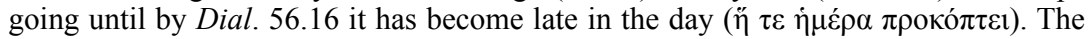
first day of debate is still not concluded when we reach Dial.74.3, where there is a gap in the manuscript (see n. 12 above). It is unclear, due to this gap, when the debate starts on the second day, but it ends late: "the day is almost at an end - for the sun is about to set" (Dial. 137.4).

21 See especially Pierre Prigent, Justin et l'Ancien testament: l'argumentation scripturaire du traité de Justin contre toutes les hérésies comme source principale du Dialogue avec Tryphon et de la première Apologie (Paris: Librairie Lecoffre, 1964).

22 Justin's works are studied and cited in this study according to Edgar J. Goodspeed, Die ältesten Apologeten (Göttingen: Vandenhoeck \& Ruprecht, 1914), which generally remains quite close to our main manuscript, Codex Paris. gr. 450 (=A). In some cases, 
I have adopted emendations, usually following one or more of the following critical editions: Munier, Saint Justin: Apologie pour les chrétiens; Marcovich, Iustini Martyris apologiae pro Christianis; Minns and Parvis, Justin, Philosopher and Martyr; Marcovich, Dialogus cum Tryphone; Bobichon, Justin Martyr, Dialogue avec Tryphon. Translations of Justin are my own, but I happily acknowledge my debt to previous translators (chiefly the fine renderings of the Dialogue by Thomas B. Falls, Thomas P. Halton and Michael Slusser [Washington, DC: The Catholic University of America Press, 2003] and of the Apologies by Minns and Parvis in Justin, Philosopher and Martyr).

23 For Rome as the Dialogue's likely place of composition, see Judith M. Lieu, Image and Reality: The Jews in the World of the Christians in the Second Century (Edinburgh: T \& T Clark, 1996), 103; Allert, Revelation, Truth, Canon, and Interpretation, 29-30.

24 I am indebted of course to Michael William's phrase "Biblical demiurgical traditions," (Michael A. Williams, Rethinking "Gnosticism”: An Argument for Dismantling a Dubious Category [Princeton, NJ: Princeton University Press, 1996], 51-3), which he proposed as a more useful descriptor than the term "Gnosticism" (on the problems associated with "Gnosticism," see also Karen L. King, What Is Gnosticism? [Cambridge, MA: Belknap, 2003], and cf. the defense of the scholarly use of the term "Gnostic" in a more limited sense in David Brakke, The Gnostics: Myth, Ritual, and Diversity in Early Christianity [Cambridge, MA: Harvard University Press, 2010]). The terms that I suggest here are descriptive and heuristic devices and are not meant to smooth over the various real differences between early Christian schools of thought, nor should they be understood as implying a distinct sociological formation (as opposed to an intellectual current). I am grateful to Daniel Boyarin for pointing out that my terminology is potentially confusing because the people in question are not worshipers or followers of the Demiurge. I recognize the difficulty, but I am not aware of an alternative term that would not be at least equally open to misinterpretation (anti-demiurgical, for instance, would likewise be ambiguous in as much as it suggests opposition to the notion of a separate demiurge).

25 For discussion of Dial. 35.5, see Chap. 5. For other demiurgists Justin may have known about, see pp. $36-37$ n. 67.

$261 \mathrm{Apol}$. must be dated between 150 and 154, according to Miroslav Marcovich, Iustini Martyris apologiae pro Christianis, PTS 38 (Berlin; New York: Walter de Gruyter, 1994), 11; cf. Leslie W. Barnard, The First and Second Apologies, Ancient Christian Writers 56 (New York: Paulist Press, 1997), 11: "somewhere between 151 and 155 C.E."; Charles Munier, Saint Justin: Apologie pour les chrétiens: édition et traduction (Fribourg, Suisse: Éditions universitaires, 1995), 6: "en 153 ou peu après."

27 E.g., Denis Minns and Paul Parvis, Justin, Philosopher and Martyr: Apologies, Oxford Early Christian Texts (Oxford; New York: Oxford University Press, 2009), 45: "Justin's primary purpose was, then, to petition for the relief of what he thought was unjust prosecution of Christians by the state authorities"; Charles H. Cosgrove, "Justin Martyr and the Emerging Christian Canon: Observations on the Purpose and Destination of the Dialogue with Trypho," VC 36 (1982): 211: "The purpose of the First Apology is to persuade Rome to apply its policy of religious tolerance to Christianity."

28 In this study I will continue the scholarly tradition of using this label as a convenient shorthand, but I doubt that anyone referred to this treatise as the Syntagma in antiquity (the label is too generic).

29 This line of argument was pioneered by Adolf von Harnack in the context of his hypothesis that Justin's true addressees were "pagans": Adolf von Harnack, Die Altercatio Simonis Iudaei et Theophili Christiani nebst Untersuchungen über die antijüdische Polemik in der alten Kirche, TU 1.3 (Leipzig: J.C. Hinrichs, 1883), 58.

30 I use the verb "convert" and its cognates here in a broad sense to refer to a change from one view to another, without implying the rejection of one "religion" for another. 
31 Too clever by half for Justin Martyr, some may object. But the problematic structuring of his works notwithstanding, Justin is not an unimaginative author. Whether 1 Apol. is judged a literary fiction or not, it is deeply innovative in its creative appropriation of the petition format (see pp. 13-14). The Syntagma was probably the first work of its kind, but even if it was not, Justin adopted a relatively new genre. The Dialogue itself shows that Justin had a creative streak and did not shy away from complexity. In Dial. 3-7, for instance, Justin relates a story about how Justin told a story about Justin. Other passages, like Dial. 80.3 with its meta-level reflexivity (see p. 42), show a similar interest in different narrative levels (and for another example, cf. Justin's comments on rhetoric in Dial. 58.1-3, with the commentary on p. 154 n. 20). Justin is clearly an author who enjoys complexity and intricacy and is interested in exploring various levels of discourse. 


\section{1 \\ JUSTIN MARTYR, HERESY HUNTER}

The life of the author of the Dialogue, Justin of Neapolis, is unfortunately not particularly well documented. Only limited external evidence has survived and much of what we do have is of late date and historically suspect. ${ }^{1}$ The best way to get to know him is therefore by studying his other compositions, in particular the (First) Apology, ${ }^{2}$ Justin's one other major preserved treatise, which was written prior to the Dialogue. ${ }^{3}$

I argue in this chapter that in $1 \mathrm{Apol}$., in addition to his evident apologetic interests (i.e., his efforts to formulate a defense of his version of Christianity to an ostensibly outside audience), Justin sought to attack and undermine other selfidentified Christians. ${ }^{4}$ The attack on these "heretics" is more central to the argument of $1 \mathrm{Apol}$. than is often recognized; whereas $1 \mathrm{Apol}$. is routinely described as an argument against the prosecution of Christians, Justin is in reality only interested in securing a better judicial position for his kind of Christians, and he works actively to undermine that of certain other Jesus-followers. He is particularly focused on Christians who do not regard the Jewish God as the Supreme Being. Justin targeted these "demiurgical Christians" not only in 1 Apol., but likely also in the lost anti-heretical treatise that he mentions in 1 Apol. 26. Justin's deep and prolonged concern with demiurgical forms of Christianity had a decisive impact on the Dialogue, as we will see in later chapters.

\section{The (first) Apology}

1 Apol. is an innovative work. It employs the Roman petition format and is addressed to the Emperors (Antoninus Pius, Marcus Aurelius, and Commodus), along with the holy Senate and the Roman people, but it transforms the genre of the Roman petition into something unprecedented. ${ }^{5}$ Because of its extraordinary length, irreverent tone, and unusual subject matter, whether it was ever accepted as a petition at the imperial court or was even intended as such has been doubted. ${ }^{6}$ Justin was presumably aware that his "apology" was very much unlike other petitions, but he may have submitted it regardless in the hope of getting a wide hearing for his message. If so, the petition format would have served as a hook that would have allowed Justin to accomplish what was otherwise so very difficult to do: get 
a Christian text in front of a non-Christian audience. ${ }^{7}$ That audience consisted of the imperial rulers in this case, and, since petitions were publicly placarded, the Roman populace more generally as well (cf. 2 Apol. 14.1). ${ }^{8}$ This scenario adequately explains, perhaps, the remarkable length and unusual subject matter of the petition, and the occasionally irreverent tone may be best seen as part of Justin's philosophical parrhèsia and his conviction that forceful language was necessary to awaken the emperors from their demon-induced slumber (cf., e.g., 1 Apol. 5.1, 14.1).

The central appeal of the Apology to the emperors, whether fictional or not, is routinely characterized as the cessation of hostilities against the Christians. This characterization is only partly accurate, because Justin actively seeks to weaken the judicial position of "other" Christians (i.e., those whom Justin would categorize as "heretics"). Justin fully develops the above-mentioned distinction between correct Christians who should be tolerated and "heretics" who ought to be persecuted only in Chapter 26, but earlier chapters lay the groundwork for this argument.

\section{Apol. 4 and 7}

The first reference to "other" Christians comes early on in $1 \mathrm{Apol}$. It appears in a section (1 Apol. 4.1-12.11) that begins with Justin's claim that "something is not judged to be either good or bad on the basis of the name by which it is called without (considering) the actions associated with that name" (1 Apol. 4.1). ${ }^{9}$ The argument that the name "Christian" should not form the basis for prosecution governs much of the discussion in this part of $1 \mathrm{Apol}$. One of the problems that Justin faces, however, is that in the eyes of at least some people a connection between the name "Christian" and illegal activities had been clearly established. Some people had apparently been convicted both of being Christian and of (other) criminal activity. Justin addresses this issue in 1 Apol. 4 and 7:

\section{Apol. 4.7-8}

(7) In the same way that some people, although they have learned not to deny from Christ the teacher, fall into error when questioned, so too, by living evil lives they equally offer pretexts to those who choose to generally accuse all Christians of impiety and injustice. (8) And this also is done unfairly. For indeed some claim the name and appearance of philosophy, who do nothing worthy of this way of life. For you know that those among the ancients who thought and taught contradictory matters are all called by one name, philosophers. ${ }^{10}$

\section{Apol. 7.1-3}

(1) But, someone will say, already some who were arrested have been exposed as criminals. (2) Indeed. This often happens in many cases whenever you closely examine the life of each one of the accused. 
But you do not sentence them on the basis of those who have previously been convicted. (3) Generally, then, we admit this, that just as among the Greeks those who taught whatever was pleasing to them are always called by the one name of philosophy, although their teachings are contradictory, so also do those among the barbarians who are and those who (only) seem wise share the same name. For they are all called Christians. ${ }^{11}$

In 1 Apol. 4.7, Justin acknowledges that some among the Christians are "living

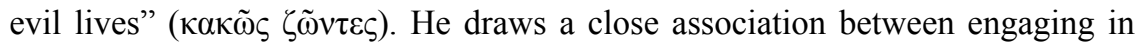
such conduct and "denying" Christ when being questioned. Justin admits, in other words, that there are people who are called "Christian," who do not live up to the demands of Jesus and in doing so offer pretexts for the Christians' opponents to claim that all of them are engaged in impious and unjust behavior.

In 1 Apol. 7.1 Justin again addresses this problem. He does not deny that some Christians have been in fact exposed as criminals, but counters that whenever one arrests a group of people (on whatever grounds) and closely examines their lives, one will find criminals among them. The Christians are no different in this regard. ${ }^{12}$

Importantly, Justin does not simply deny that Christians are involved in illegal activities or claim that the convictions referred to in 1 Apol. 7.1 were wrongful. Perhaps he felt that it would have been needlessly antagonizing to suggest that the Roman judicial apparatus had failed by unjustly convicting Christians of crimes. Elsewhere, though, Justin is not afraid to harshly criticize Roman policy and practice. In the immediate context, for example, he tells the emperors: "with irrational passion, and driven under the whip of despicable demons you punish us without any consideration" ( $1 \mathrm{Apol}$. 5.1) ${ }^{13}$ Alternatively, public perceptions that Christians were involved in criminality may have been too deeply rooted for Justin to simply dismiss these accusations as nonsensical. Indeed, they may not have been nonsense at all; the cases referred to in $1 \mathrm{Apol}$. 7.1 may have been indisputable facts. In light of what follows, however, I suggest that part of the reason for Justin's willingness to admit that some Christians were involved in crimes is that doing so will give him a figurative stick with which to beat the "heretics." $\mathrm{He}$ will suggest that the "heretics" committed immoral and criminal acts while falsely claiming the name "Christian." His association of those among the Christians who "fall into error" with the accusations of impiety and unjustness in 1 Apol. 4.7 already sets up this argument. Justin will try to convince his audience that because of the criminal conduct as well as the "atheistic" teachings of these "other" Christians, they are the ones who deserve Roman prosecution. ${ }^{14}$

$1 \mathrm{Apol} .4$ and 7 begin to prepare the audience for this remarkable claim inter alia by describing Christian diversity as analogous to the diversity apparent among philosophers. The significance of the analogy with philosophy to Justin's heresiology is evident from his use of it twice in the space of just a few paragraphs (in 1 Apol. 4 and 7) and then a third time in 1 Apol. 26, where he develops the 
comparison further. The first part of $1 \mathrm{Apol}$. 4.8, where Justin sets up the analogy with philosophy, is suitable to his argument that the crimes of some Christians should not be held against all Christians. He writes, "some claim the name and appearance of philosophy, who do nothing worthy of this profession." Attacks on faux philosophers are widely attested in the literature of this period. ${ }^{15}$ Critics such as Lucian of Samosata were unrelenting in their disdain for those who falsely claimed the name (ő $v \mu \alpha)$ and appearance $(\sigma \chi \tilde{\eta} \mu \alpha)$ of philosophy. Justin draws on this literary trope in 1 Apol. 4.8 when he dismisses the charges against the Christians in general as unfair, because the case is similar to that of philosophy, where "some claim the name and appearance of philosophy, who do nothing worthy of this way of life." "16 Justin suggests that the Christians were confronted with the same problem that the false philosophers posed to the philosophical tradition. They too confronted people who claimed the ôvo $\mu \alpha$, but did not live in accordance with the tradition's ideals.

What follows in 1 Apol. 4.8 is slightly less apropos. "For you know," Justin writes, "that those among the ancients who thought and taught contradictory matters are (all) called philosophers." The problem at hand is that some Christians have been convicted of crimes. They are giving Christians a bad reputation through their conduct, not their teaching. Likewise, in 1 Apol. 7, Justin refers to differences in teaching even though the issue he responds to is that of Christians being condemned because of criminal activity. This focus on "teaching" might seem out of place in the context, but its appearance should probably not be understood as the result of sloppiness. Rather, Justin is beginning to develop the idea that those who hold different teachings (i.e., the "heretics") are responsible for the crimes committed.

The statement immediately following in 1 Apol. 4.9 is worth noting in this connection. Justin writes, "Some of them [the philosophers of old] taught atheism and those who were poets proclaimed the licentiousness of Zeus and his children, and those who follow them are not barred from your presence, but you offer prizes and honors to those who insult them [the gods] in a pleasing manner." ${ }^{17}$ According to Justin, philosophical ideas that are atheistic receive the emperors' approval in the form of praise for artists whose performances incorporate such ideas. In what to Justin is an absurd contradiction, Christians are prosecuted for their alleged "atheism," while those who openly teach "atheism" receive praise. Justin will develop the same argument in relation to the "heretics" in subsequent sections of 1 Apol.: they teach atheism, yet they receive more favorable treatment than the "true" Christians.

\section{Apol. 16}

Following this section (1 Apol. 4-12), Justin moves on to a new topic: "we will demonstrate that we revere, on good grounds, Jesus Christ, who became the teacher of all these things to us and was born for this" (1 Apol. 13.3) ${ }^{18}$ Justin cites a number of sayings of Jesus to demonstrate their ethical quality and potency 
in 1 Apol. 15-16 and intersperses them with comments regarding their positive effects on "those who have joined us" ( $\tau \tilde{\omega} \nu \pi \alpha \rho$ ' $\dot{\eta} \mu \tilde{v} v \gamma \varepsilon \gamma \varepsilon v \eta \mu \varepsilon \varepsilon^{\prime} \omega \nu$ [1 Apol. 16.4], cf. 15.6-7, 17.1). At the end of 1 Apol. 16, Justin addresses the problem that Jesus's words did not, apparently, change everyone for the better:

\section{Apol. 16.8-14}

(8) And let those who are not found to be living as he taught be known as non-Christians, even if they utter the teachings of Jesus with their tongue. For he said that not those who only speak, but those who do the works will be saved. (9) He said: "Not everyone who says to me 'Lord, Lord' will enter into the kingdom of heavens, but the one who does the will of my Father who is in heaven. (10) For he who listens to me and does what I say listens to the one who sent me. (11) And many will say to me: 'Lord, Lord, did we not eat and drink and perform miracles in your name?' And then I will say to them: 'Go away from me, workers of lawlessness.' (12) Then there will be weeping and gnashing of teeth; while the righteous shine like the sun, the unrighteous are sent into the eternal fire. (13) For many will come in my name, outwardly clothed in sheep's clothing, but inwardly being ravaging wolves; you will know them by their works; every tree that does not produce good fruit is cut down and thrown into the fire." (14) We request from you as well that those who do not live in conformity with his teachings, but are only called Christians, be punished. ${ }^{19}$

Here Justin states for the first time that some people are only "so-called" Christians

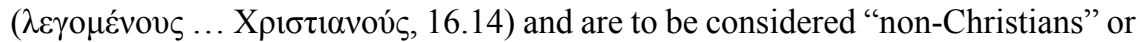

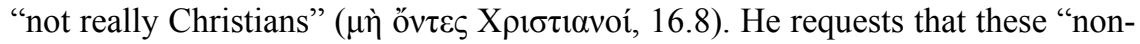
Christians" be punished at the end of the present passage. The request follows logically from his earlier argument that judicial decisions should be made on the basis of actions, not the name "Christian," and it takes up similar statements in 1 Apol. 3.1 and 7.4. Importantly, however, in the present passage Justin describes the conduct that ought to receive punishment from the emperors not simply as whatever is criminal from the point of view of the Roman legal system, but as whatever is not in conformity with the teachings of Jesus. This is a notable difference. Justin requests the punishment of those who lay claim to Jesus's teachings (1 Apol. 16.8), yet fail to live in conformity with them (1 Apol. 16.14). In other words, Justin requests imperial action against the "so-called" Christians. By appending his request to the reference to divine punishment in 1 Apol. 16.13 ("every tree that does not produce good fruit is cut down and thrown on the fire"), Justin depicts the imperial punishment of these people as conforming to, and indeed actualizing, the words of Jesus. This is eerily similar to (post-)Constantinian attempts to enlist imperial force to repress "heresy." As we will see, Justin claimed that certain "her-

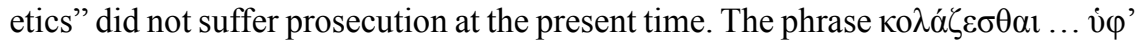


$\dot{v} \mu \tilde{\omega} \nu \dot{\alpha} \xi 10 \tilde{u} \mu \varepsilon v(1$ Apol. 16.14) is therefore best understood not as a polite recognition of the emperor's right to dole out punishment (one possible meaning of $\alpha \dot{\xi}$ ió $\omega$, especially with the infinitive), but rather as a request for the prosecution or even persecution of "so-called" Christians. ${ }^{20}$

\section{Apol. 26 and 56-58}

The complaint that these believers are not currently being prosecuted appears in Chapter 26, the most significant passage on Christian deviance in $1 \mathrm{Apol}$. and the centerpiece of Justin's attack on his opponents in this treatise. In the immediate context, Justin is trying to persuade his audience that "evil demons ... brought about the accusations against us of infamous and impious deeds" (1 Apol. 23.3). ${ }^{21}$ The deeds in question are specified in 1 Apol. 26.7 as " 'throwing down the lamp,' shameless intercourse and consuming human flesh." 22 According to Minucius Felix (Octavius 9.6), such accusations were uttered by none other than M. Cornelius Fronto, who was the tutor of Marcus Aurelius and Lucius Verus. He was appointed to this position by Antoninus Pius, who held him in very high regard. ${ }^{23}$ If Minucius Felix's report is accurate, then Justin may be responding to rumors spread by someone who was very close indeed to the imperial family to which 1 Apol. is addressed. This may shed further light on the reasons behind the composition of $1 \mathrm{Apol}^{24}$ But be this as it may, in 1 Apol. 26 Justin seeks to explain the true origins of these malignant rumors. He claims that the demons raised up certain people and it is they, Justin implies, who were engaged in those infamous deeds of which the Christians are falsely accused (1 Apol. 26.7). ${ }^{25}$

\section{Apol. 26}

Thirdly, (that) also after Christ's ascension to heaven, the demons put forth certain people who said that they themselves were gods, who were not only not prosecuted by you, but even considered worthy of honors; (2) Simon, a certain Samarian, from a town called Gittha, who during the rule of Claudius performed magical powers through the cunning of the demons who were active in him, was considered a god in your royal city of Rome and was honored by you as a god with a statue. This statue was erected in the river Tiber, between the two bridges, with the following Latin inscription: "To Simon the Holy God." (3) And almost all of the Samarians, and a few also among other peoples, confess and worship him as the first God. And a certain Helen, who was traveling about with him during that time, having formerly been placed in a brothel - they say that she is the First Thought that originated from him. (4) And a certain Menander, himself also a Samarian, from the town of Capparetaea who became a disciple of Simon, having been put to action by the demons, we know that he came to Antioch to mislead many through magical art. $\mathrm{He}$ persuaded his followers that he would never die, and still now there are 
some who believe this about him. (5) And a certain Marcion of Pontus, who even still now teaches his devotees to consider another god greater than the Creator. With the assistance of the demons he caused many in every race of people to speak blasphemies and to deny God, the Maker of this universe, and to confess that another, greater being has created greater things than he. ${ }^{26}$ (6) All who got their start from them, as we said, are called Christians, in the same way that they who do not share the teachings of the philosophers are called by the common name of "philosophy." (7) Whether they do those shameful things that have been rumored, "throwing down the lamp," shameless intercourse and consuming human flesh, we do not know. But we are aware that they are neither prosecuted nor killed by you, at least not because of their teachings. (8) A document against all the heresies that have come into existence has also been composed by us, which we will give you if you wish to obtain it. ${ }^{27}$

Justin's claims about the "heretics" here build on the sections discussed above (1 Apol. 4, 7, 16). This is evident from 26.6, where Justin notes, "All who got their start from them, as we said, are called Christians, in the same way that they who do not share the teachings of the philosophers are called by the common name 'philosophy." The heretics mentioned in this passage are aligned with the Christians who, like certain self-identified philosophers, "live evil lives" (1 Apol. 4.7) and who "were exposed as criminals" when examined by the Romans (1 Apol. 7.1). It is they whom Justin had in mind when he referred to "those who only seem wise" (1 Apol. 7.3) and when he spoke of those who are "not really Christians" but only "so-called" Christians in 1 Apol. 16.8 and 16.14. In the present passage Justin specifies the kind of activities that they may have been involved in: "Whether they do those shameful things about which rumors have been going around, 'throwing down the lamp,' shameless intercourse and consuming human flesh, we do not know" (1 Apol. 26.7). Such accusations were lodged against the Christians indiscriminately, but Justin responds by suggesting that only some "Christians" were to blame; the heretics may have committed such acts, rendering them responsible for the Christians' poor reputation. Justin knows that "true Christians" would never do such things, but he cannot speak for his heretical rivals, thereby implying that they may very well be guilty of these immoral and criminal activities. This argument dovetails with Justin's earlier claim that certain Christians who have "fallen into error" are offering "pretexts to those who choose to generally accuse all Christians of impiety and injustice" (1 Apol. 4.7).

To understand why Justin singled out these specific "heretics," we must take a closer look at his targets. The focus of attention in 1 Apol. 26 is on Simon Magus (together with his entourage, Helen and Menander) and Marcion. Their names are so familiar that few have asked why these two figures are singled out for attack by Justin in the first place. It seems clear why Marcion is mentioned: he posed the most immediate threat from Justin's perspective. Simon Magus was

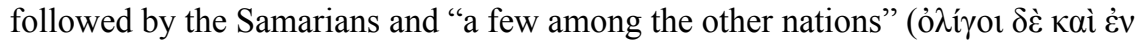




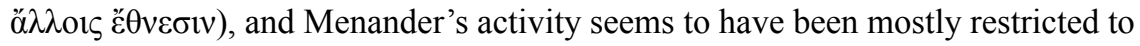
Antioch. By contrast, Marcion held sway over "many" ( $\pi \mathrm{o} \lambda \lambda \mathrm{o}$ i) "in every race of

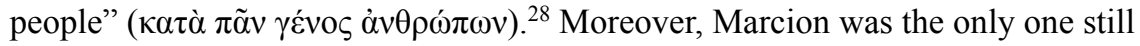

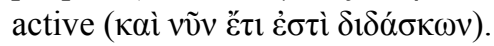

But why Simon? It is routinely suggested that Simon is named to link Marcion to an arch-heretic: ${ }^{29}$ Simon is mentioned in his role of "father of all heretics," and Marcion is cast as the successor to this magician who had already been definitively refuted by the apostles (Acts 8 ). ${ }^{30}$ Justin does not, however, mention any kind of succession linking Simon or his disciples to Marcion and it is actually Irenaeus who first labels Simon the "father of all heretics" (A.H. 3, preface). Moreover, Justin does not refer to Acts 8, which means that he is not simply introducing Simon in order to manufacture an apostolic condemnation of Marcion. Clearly, Justin's interest in Simon is not primarily motivated by Acts. Another reason why Simon's role cannot be reduced to that of providing an arch-heretical backdrop for Marcion is that Justin intimates genuine concern about Simon and his teaching. He claims that Simon "was considered a god in your royal city of Rome and was honored by you as a god with a statue" (1 Apol. 26.2). Justin likely referred to a statue devoted to Semo Sancus, not Simon. It is improbable, however, that the mistake originated with Justin. ${ }^{31}$ More likely, Justin received his information from fellow Samarians, "nearly all" of whom, he claims, confessed Simon as "the First God" (1 Apol. 26.3, cf. 56.1). In 1 Apol. 56, Justin adds further details. He claims, "Having come to royal Rome under Claudius Caesar, Simon amazed the holy Senate and the Roman people to such a degree that he was considered a god and was honored with a statue" (56.2) ${ }^{32}$ The matter was so important that Justin continues, "we ask that you receive the holy Senate and your people as joint adjudicators of this petition of ours, so that if anyone is under the sway of his teaching he might flee from this error upon learning the truth. And if you wish, take down the statue" $(56.3-4) .{ }^{33}$

It is difficult to imagine that Justin made these extraordinary statements simply on the basis of a cursory reading of an inscription on the Insula Tiberina that he happened to come across. ${ }^{34}$ Not least because he himself hailed from Samaria, it is much more plausible that the legend of Simon's favorable reception by the Roman elite was circulating among the Samarians and was not simply the product of Justin's imagination. ${ }^{35}$ Justin accepted these stories as reliable and evidently considered it necessary to discuss them in 1 Apol. It is clear, then, that Justin's interest in Simon went considerably beyond his alleged status as an arch-heretic and that Justin did not mention him solely to associate Marcion with a "heretic" from the past.

But what drove Justin to attack Simon in this particular context alongside Marcion? The chapter opens with the statement "the demons put forth certain people who said that they themselves were gods." This description fits Simon, but not Marcion. ${ }^{36}$ Although Justin may have intentionally allowed the impression that Marcion proclaimed himself a god, he presumably knew that this was inaccurate 
and there must have been some other, underlying reason for closely associating the two ${ }^{37}$ I suggest that Justin observed a degree of theological continuity between Simon and Marcion. What they had in common was that they both denied that the Creator was the Supreme Being. Marcion claimed that the Creator was an inferior figure and that someone else was greater than him (1 Apol. 26.5). Simon, Justin says, was known as "the First God" among the Samarians (1 Apol. 26.3), which suggests that he too did not acknowledge the true Creator (i.e., the Jewish God, in Justin's view) as the Supreme Being. The expression "First God" implies that, like Marcion, Simon (and/or his followers) posited that the Creator was a secondary figure. The label "First God" has largely escaped the attention of commentators, but it is highly significant. In the philosophical parlance of the time, especially of the Middle Platonism with which Justin was familiar, the term "First God" was relatively common..$^{38}$ Alcinous (Albinus ${ }^{39}$ ), for instance, states that the "First God" is "eternal, ineffable, 'self-perfect' (that is, deficient in no respect), 'everperfect' (that is, always perfect), and 'all-perfect' (that is, perfect in all respects); divinity, essentiality, truth, commensurability, $<$ beauty $>$, good. ${ }^{40}$ This First God is "first" not only in the sense that he is Supreme, but also in that he is followed by other, lower-ranking gods. Justin himself understands "First God" in this twofold way. This is apparent from 1 Apol. 60.5, where he writes, "Plato, because he did not accurately understand and did not realize that it was an image of a cross, believing instead that it was an X-formation, said that the power after the First God was 'arranged as an $\mathrm{X}$ in the universe."'41

Alcinous distinguished between the First God and the "gods creating ("demiurging') the mortal classes of being" (23.1). ${ }^{42}$ For Numenius, who was active right around the time of Justin and whose thinking exhibits a number of striking convergences with that of Justin, ${ }^{43}$ the "First God" was likewise distinct from the Demiurge: "In fact the First (God) should not create either. Indeed, the First God must be considered the father of the Creator God" $(F r .12) .{ }^{44}$ Furthermore, according to Numenius, "The relationship between the First God and the Demiurge is just like that between the farmer and the one who does the actual planting" $(F r .13$, cf. also Ps-Plutarch, On Fate, 572F-573A). ${ }^{45}$ The label "First God" was evidently frequently used to distinguish the Supreme God from the Demiurge (and other lower-ranking divinities) ${ }^{46}$

Justin's calling Simon the "First God" suggests that he was likewise regarded as the Supreme Being in contradistinction to a second (and third, etc.) god, among whom we would expect the Demiurge(s). This fits with Justin's comment that Helen was regarded as the "first thought that came to be from him [Simon]." Helen presumably stood at the head of a series of emanations that included the Demiurge among the lower beings. Simon's theology, in other words, likely matched what Irenaeus ascribed to Cerinthus, where we again find the expression

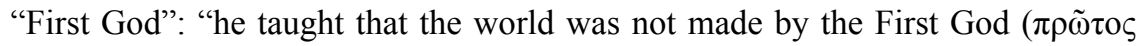
$\left.\theta \varepsilon \varepsilon_{\varsigma}\right),{ }^{48}$ but by a certain Power far separated from him, and at a distance from that Principality who is supreme over the universe, and ignorant of him who is 
above all" (A.H. 1.26.1) ${ }^{49}$ Indeed, Irenaeus probably captured Simon's teaching (as Justin understood it) accurately when he wrote:

He represented himself, in a word, as being the loftiest of all powers, that is, the Being who is the Father over all ... Ennoea (i.e., Helen) leaping forth from him, and comprehending the will of her father, descended to the lower regions [of space], and generated angels and powers, by whom also he declared this world was formed... As to himself, they (the angels and powers) had no knowledge of him whatever.

In sum, the evidence suggests that (according to Justin's understanding) Simon distinguished between the First God and a lower, inferior divinity or group of divinities that created the world. Hence Justin understood both Marcion and Simon as figures who posited a First/Supreme God in contradistinction to a lower creator-god and denied the true (Biblical) God his rightful place as the Supreme Being. ${ }^{50}$ While Simon was by no means the only such "demiurgist," Justin's conviction that the Romans had paid Simon manifold honors made him particularly relevant in this treatise addressed to the Roman government.

To Justin's mind, this demiurgism shared by Marcion and Simon equated with atheism. At various moments on the preceding pages of 1 Apol., Justin responds to the allegation that Christians were "atheists" (e.g., 1 Apol. 6.1) by arguing that they in fact believe in the God who created the world (i.e., the Demiurge). ${ }^{51}$ Especially important in this connection is 1 Apol. 13.1-2, where Justin writes: "What person of sound mind will not agree that we are not atheists given that we worship the Demiurge of this Universe?"52 Christians cannot be regarded as atheists, he argues, since they do indeed worship the Demiurge. This logically implies that those who do not worship the Demiurge are atheists. As Justin states in $1 \mathrm{Apol}$. $58.1-2$, those who follow Marcion in "renouncing the Creator God" ( $\dot{\alpha} \rho v \varepsilon i \tilde{\sigma} \theta \alpha 1 .$.

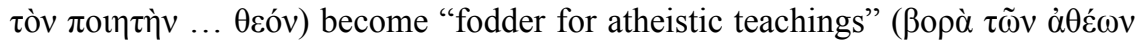

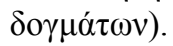

The case of these demiurgical atheists was advanced by the demons, whose first priority, Justin tells us, was to drive people away from the Demiurge. The "so-called demons strive for nothing else than to lead humans away from God the Maker and from his first-begotten Christ" (1 Apol. 58.3). ${ }^{53}$ Justin detected a pattern recurring throughout history where, under the influence of these demons, the rulers advanced the case of the atheists, while prosecuting as atheists those who were actually seeking to root out atheism. The prime example is Socrates. He sought to unmask the gods as demons (1 Apol. 5.2; 2 Apol. 10.6) and thereby bring to an end the atheistic practice of demon worship. But, paradoxically, he was convicted on charges of atheism by those in power in Athens 1 Apol. 5.3, cf. 2 Apol. 10.5). ${ }^{54}$ That Socrates was not an atheist is clear from the fact that he urged the people to search for "the Father and Demiurge of All" (2 Apol. 10.6). 
Meanwhile, the ancient philosophers who did espouse atheism received favorable treatment. The emperors praise these atheists by giving prizes to the performers who proclaim their teachings, Justin complains (1 Apol. 4.9). Simon is another example of an "atheist" (i.e., someone who does not worship the Demiurge) who was nonetheless welcomed and granted significant honors by the Roman government. At the same time, the "true" Christians, who are least atheistic of all since they do worship the Demiurge (1 Apol. 13.1), are prosecuted by the government on charges of atheism. Justin presumably hoped that his Apology would help the emperors recognize that, if they continued down the path of prosecuting Christians, they were in danger of becoming like the Athenians of old who killed Socrates. Justin urged them to recognize that "true" Christians were not atheists and to focus their prosecutory energy instead on those who were, including "false" Christians.

As noted above, according to Justin, prosecution and/or persecution of "socalled" Christians is precisely what was not happening. He twice makes the remarkable claim that the heretics got off scot-free (1 Apol. 26.1, 7). The second time he nuances the claim slightly. "We are aware," he writes, "that they are neither prosecuted nor killed by you, at least not because of their teachings." I suggest that this perplexing comment reflects Justin's awareness of the logical tension in the claims that he was advancing. ${ }^{55}$ On the one hand, he implied that the "heretics" were those who turned out to be criminals when the Romans examined them, but on the other hand he argued that they were not being prosecuted. These claims are somewhat difficult to reconcile, which is most likely why Justin adds "at least not because of their teachings." As we noted above, for Justin their teachings amounted to "atheism." The logic behind his curious comment is that, even though the emperors were ostensibly opposed to "atheism," they did not persecute the demiurgists because of their "atheistic" teachings. To the extent that they were persecuted this happened because of the wicked acts that they commited or because of the mistaken assumption that they were Christians, but not because they were recognized for what they really were (i.e., atheists who failed to worship the Demiurge). Justin grants that Marcionites and other "heretics" have been convicted by the Romans, which is in fact how the Christians came to be accused of the crimes confessed by the heretics, but he maintains that this happened for the wrong reasons. It is in this sense that Justin can claim that the heretics are not being prosecuted.

The disinterest of the Romans in Marcion's atheistic teaching matches their treatment of Simon Magus, some of the philosophers, as well as the accusers of Socrates. All of them promoted or facilitated "atheism," yet elicited a favorable response from those in power. Justin seeks to ensure that the Romans will not treat his rivals in similarly favorable fashion. Instead, he wants the Romans to actively oppose them, since these heretics are, Justin claims, the real criminals and actual atheists. In the hope that the emperors are interested in following up on this point, Justin mentions that he has a document available listing all the various heresies. 


\section{The Syntagma}

Had Justin not referred to this important text here, we would have been unaware of it. Irenaeus mentions a "Syntagma against Marcion" ( $\tau$ ò $\pi \rho$ ò $\varsigma$ M $\alpha \rho \kappa i ́ \omega v \alpha$

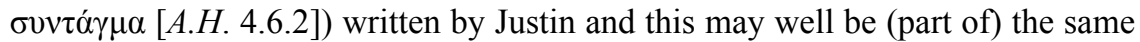
document. ${ }^{56}$ But since the document itself has not been preserved, we would have had no idea that Justin targeted "all" heresies (and not just Marcion), nor would we have known that it was composed prior to 1 Apol. ${ }^{57}$

Whether Justin himself was responsible for the composition of the Syntagma has been questioned in recent scholarship, but I have argued elsewhere that this view remains the most plausible hypothesis. ${ }^{58}$ Beyond that, there is little that we can know about the Syntagma with any degree of certainty, despite the fact that scholars have sometimes made sweeping claims about this text. ${ }^{59}$ I suggest, however, that there is one important thing that we can reasonably surmise about the Syntagma that has not received attention in earlier scholarship and that is significant for our understanding of Justin's heresiology: all of the groups targeted in this document advocated a form of Christian demiurgism.

Most scholars agree that there must have been some relationship between the Syntagma and 1 Apol. 26. The descriptions of Simon, Menander, Helen, and Marcion in that chapter likely derive, at least in part, from the Syntagma. We have argued that Simon occupies a prominent place in 1 Apol. not least because of the warm welcome that he allegedly received from the Roman government. It is not certain, therefore, that in a different context he received a similarly impressive share of Justin's attention. In the Dialogue his role is very limited, and this may have been the case in the Syntagma as well. ${ }^{60}$ Since Marcion was clearly the primary heretical threat in $1 \mathrm{Apol}$., it is probable that he was also the predominant figure of the Syntagma, and this could then explain why Irenaeus speaks of a "Syntagma against Marcion."

But which other teachers were mentioned in the Syntagma? To answer this question, scholars have turned to later texts that may have been dependent on it. A particularly compelling possibility is that Irenaeus drew on the Syntagma in A.H. 1.23-27, part of the section in which he seeks to expose the "mothers and fathers and ancestors" of the Valentinians (1.30.3). ${ }^{61}$ Each of the heresies mentioned in Justin's corpus appears in this part of Irenaeus's massive treatise. The Valentinians are the exception to this observation, but since they are Irenaeus's primary target and are mentioned a little later in A.H. 1.30, this is no serious difficulty. There are also similarities in the order in which the heresies are mentioned. Irenaeus, like Justin, begins with Simon, Helen, and Menander; and he too ends with Marcion. There are also striking parallels in their respective descriptions of these four characters: Simon was honored as a god, a statue in his honor was erected in Rome; Helen, the former prostitute, was the "first thought" of Simon; Menander, a follower of Simon, was a magician who claimed immortality for himself, etc. Moreover, as noted above, Irenaeus indicates familiarity with an anti-heretical Syntagma by Justin. In short, the theory that Irenaeus drew 
on Justin's Syntagma in this section has merit, even though certainty in the matter is admittedly elusive.

Even so, regarding A.H. 1.23-27 as a copy of Justin's Syntagma is unwarranted. This was essentially the approach of R. A. Lipsius, who wrote during the heyday of source-criticism. He assumed that every group mentioned by Irenaeus was also mentioned in the Syntagma, unless something precluded this possibility. His approach identifies passages that were not part of the Syntagma, but it does not allow describing with any degree of certainty what was included in that text. We must surely keep open the possibility that Irenaeus derived information from other sources, oral or written, and that he introduced material of which he himself was the primary source. Although we cannot determine the precise contents of the Syntagma on the basis of A.H. 1.23-27, the work of critics like Lipsius remains helpful in isolating passages that were certainly later additions. It can be excluded, for instance, that Irenaeus drew on the Syntagma when he wrote: "A certain Tatian was the first to introduce this blasphemy. He had been a follower of Justin and, as long as he was with him, he did not express such a view. However, after Justin's martyrdom, he apostatized from the Church" (A.H. 1.28.1). For obvious reasons, this could not have been written by Justin. The "blasphemy" introduced by Tatian is that of the Encratites and they were therefore not included in Justin's Syntagma. It is likewise unlikely that the Ebionites (1.26.2) were included in Justin's Syntagma, because Justin had a relatively liberal attitude towards Torah-oriented forms of Christianity. ${ }^{62}$ The Nicolaitans may also have been added later, since they derived from Nicolaos, rather than Simon (1.26.3) ${ }^{63}$ It is possible in all three cases (Encratites, Ebionites, Nicolaitans) that Irenaeus introduced them into the catalogue on the basis of information derived from another source altogether, but it is also a possibility that they were added to the Syntagma by a previous, unknown editor. ${ }^{64}$

Each of the groups that were most likely later additions to the Syntagma (Encratites, Ebionites and Nicolaitans) did not posit an inferior Demiurge, unlike all of the other groups that Irenaeus discusses in this section. ${ }^{65}$ That means that all the groups mentioned in A.H. 1.23-27 that could have been derived from Justin's Syntagma share the notion of a Demiurge who stands in opposition to the Supreme God. They do not, in Justin's parlance, properly worship the "Father and Demiurge of All." We have already argued that this is also what Simon and Marcion had in common in Justin's view. In 1 Apol. 26.6, Justin refers to them when he says "All who got their start from them, as we said, are called Christians." The "so-called" Christians in view here are likely the people who were discussed in the Syntagma, which is mentioned shortly afterwards. ${ }^{66} \mathrm{We}$ would expect that those who "got their start" from Simon and Marcion, that is to say those who are featured in the Syntagma, shared their demiurgism. Thus we see that the pieces of the puzzle fit together. Those who "got their start from" Simon and Marcion and are mentioned in the Syntagma must have agreed with Simon and Marcion's view that the Demiurge was not the Supreme God, a view that these two men had in common. And indeed, all of the groups mentioned by Irenaeus that could potentially go back to the Syntagma are said to have adhered to this notion. ${ }^{67}$ 


\section{Conclusion}

This chapter has argued that in both 1 Apol. and the Syntagma, Justin was deeply concerned with "heresy." Rather than attempting to deliver Christians in general from imperial tyranny, $1 \mathrm{Apol}$. seeks to improve the judicial position of Justin's form of Christianity. It does so in part by actively undercutting "heretical" alternatives. Heresy was central to Justin's overall argument, because it allowed him to shift the blame for criminal and immoral activities rumored about Christians to certain "others," whom he presented as not Christian at all. What these "non-Christians" had in common (to Justin's mind) was their denial that the true (Biblical) God was the Supreme Being. Under the influence of demonic forces, they posited a Demiurge, who was distinct from the First God and therefore construed as an inferior being. In contrast to the "true" Christians, they did not "worship the Demiurge," which marked them as atheists in Justin's view.

Important examples of such demon-inspired people who failed to recognize the supremacy of the Jewish God were Simon and Marcion, to both of whom Justin devotes considerable discussion in $1 \mathrm{Apol}$. The people "who got their start" from Simon and Marcion were presumably included in the lost Syntagma (1 Apol. 26.8). Once later additions to the list of heresies in Irenaeus's Adversus Haereses, which may well be based on the Syntagma, are removed, it becomes clear that all of the entries in that catalogue that could potentially go back to Justin's anti-heretical treatise promoted Christian forms of demiurgism. On various levels and in various ways, then, both $1 \mathrm{Apol}$. and the Syntagma attacked demiurgical Christians. Justin had evidently been deeply invested in combatting them for a long time prior to composing the document that is at the heart of the present study, the Dialogue with Trypho ${ }^{68}$ We will commence our analysis of this text in the next chapter by considering the complex prolegomenon of the Dialogue's intended audience.

\section{Notes}

1 See Eric Francis Osborn, Justin Martyr, BHTh 47 (Tübingen: Mohr Siebeck, 1973), $8-11$.

2 The debate about whether Justin wrote one or two apologies remains unresolved; our focus here will be on what is traditionally known as the First Apology, by far the longest of the two documents (or, alternatively, the most extensive part of the one document). For discussion, see, e.g., Paul Parvis, "Justin, Philosopher and Martyr: The Posthumous Creation of the Second Apology," in Justin Martyr and His Worlds, ed. Sara Parvis and Paul Foster (Minneapolis, MN: Fortress Press, 2007), 22-37, and the literature cited there.

3 In Dial. 120.6, Justin refers back to 1 Apol.

4 "Apologetic" should not in this context be taken to mean that Justin was somehow operating apart from or over against the Greek world. Justin's argument is very much an appeal for a reconfiguration within Hellenism, as has been stressed by Lyman, "2002 NAPS Presidential Address"; J. Rebecca Lyman, "The Politics of Passing: Justin Martyr's Conversion as a Problem of 'Hellenization'," in Conversion in Late Antiquity and the Early Middle Ages: Seeing and Believing, ed. Kenneth Mills and Anthony Grafton, Studies in Comparative History (Rochester, NY: University of Rochester Press, 2003), 36-60. 
5 Minns and Parvis suggest that the inclusion of the Senate and Roman people in 1 Apol. 1.1 is an early editorial addition (Justin, Philosopher and Martyr, 34-6). It is in any case readily apparent that Justin primarily addresses himself to the emperors. As William R. Schoedel, "Apologetic Literature and Ambassadorial Activities," HTR 82 (1989): 75-76, notes: "it is the emperor and his sons whom Justin really has in view."

6 Scholars like Charles Munier, "À propos d'une édition récente des Apologies de Justin," Revue des Sciences Religieuses 71 (1997): 299-309 and P. Lorraine Buck, "Justin Martyr's Apologies: Their Number, Destination, and Form," JTS 54 (2003): 45-59, have argued that $1 \mathrm{Apol}$. is best understood as a literary fiction. Sebastian Moll, "Justin and the Pontic Wolf," in Justin Martyr and His Worlds, ed. Sara Parvis and Paul Foster (Minneapolis, MN: Fortress Press, 2007), 145-151, responds to Buck's arguments. Fergus Millar's assessment remains compelling in my view (The Emperor in the Roman World, $31 B C-A D 337$ [Ithaca, NY: Cornell University Press, 1977], 563): "it is at least as convincing, and far more economical, an explanation of its contents and its concrete references to events, to suggest that it actually was presented - or was intended to be presented - to the emperors, as that it is an elaborate fiction." The question is ultimately of limited relevance for the argument of this chapter.

7 Cf. Minns and Parvis, Justin, Philosopher and Martyr, 25: "[Justin] has managed to hijack a normal piece of Roman administrative procedure and turn it into a device for getting his message, literally and symbolically, to the heart of the Roman world. We need to remember the extent to which Justin and his fellow believers were outsiders, and how difficult it was for them to get a wider hearing in that smug, self-satisfied world." That Justin himself reckoned with a broader audience besides the imperial family is clear from Dial. 120.6: "I was unconcerned about any of my people, I mean the Samarians, when, while I was addressing the Emperor in writing, I said that they were deceived since they were persuaded by the magician Simon, who is among their

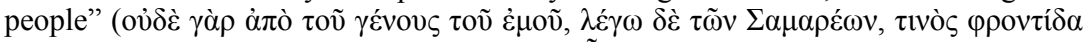

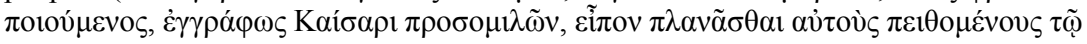

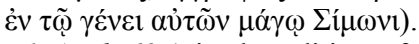

$8=1$ Apol. 69.1 in the edition of Minns and Parvis (Justin, Philosopher and Martyr, 266-7).

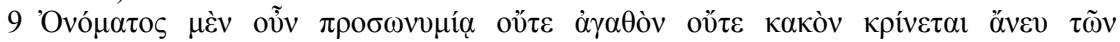

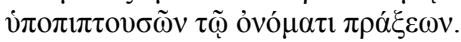

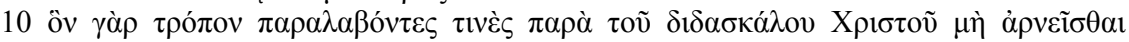

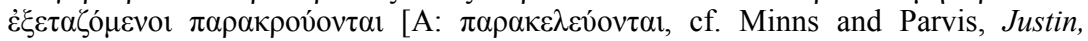

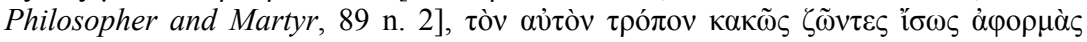

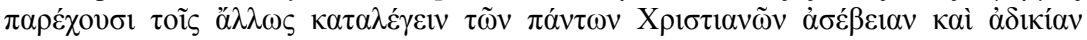

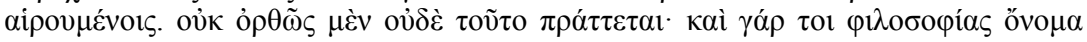

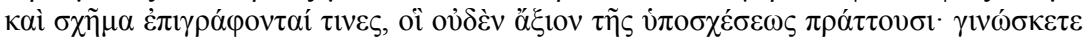

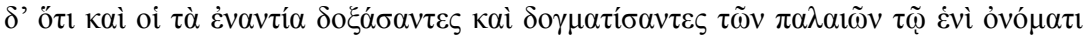

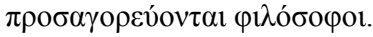

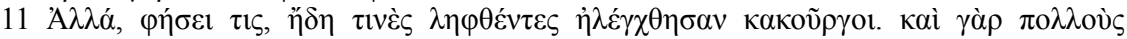

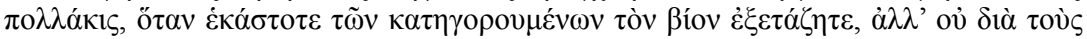
$\pi \rho 0 \varepsilon \lambda \varepsilon \gamma \chi \theta \dot{\varepsilon} v \tau \alpha \varsigma$ [with Marcovich, Minns-Parvis et al. I adopt this reading instead of A's

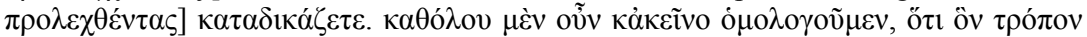

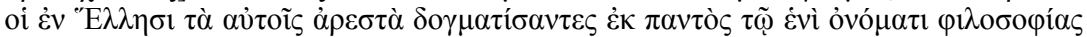

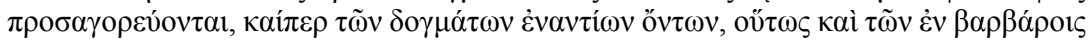

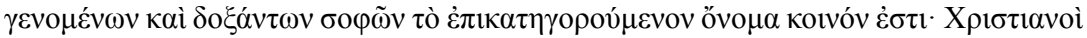
$\gamma \grave{\alpha} \rho \pi \alpha ́ v \tau \varepsilon \varsigma \pi \rho o \sigma \alpha \gamma o \rho \varepsilon v ́ o v \tau \alpha 1$.

12 With Minns and Parvis, Justin, Philosopher and Martyr, 93 n. 3, I take 1 Apol. 7.2 to refer to accused people in general, not to Christians specifically. Justin's point is that in other cases people are not condemned because certain people who belong to the same class have been convicted in the past. Instead, the decision is made on the basis of an 
inquiry of the individual case, and this is what Justin requests for the Christians as well. He admits that some Christians have been involved in criminal activities, but argues that this should not be indiscriminately held against all Christians; criminality, he suggests, is not inherent in the Christian name.

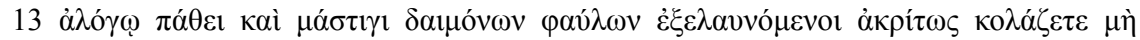
$\rho \circ \nu \tau i \zeta \zeta o v \tau \varepsilon \varsigma$

14 The general idea that Justin tries to shift the blame from the "real" Christians to the heretics has been recognized by other scholars, even if its implications and the way that Justin develops his case have received little attention. See Robert Joly, Christianisme et philosophie: Études sur Justin et les apologistes grecs du deuxième siècle (Bruxelles: Éditions de l'université de Bruxelles, 1973), 162-3; Le Boulluec, La notion d'hérésie, 62; Smith, Guilt by Association, 111-12 n. 206.

15 As Jennifer Hall, Lucian's Satire, Monographs in Classical Studies (New York: Arno Press, 1981), 189-90 puts it, with but slight exaggeration: "Lucian says that it would be easier to fall in a boat and miss a plank than it would be in his age to miss a philosopher wherever one looks (Bis Acc. 6). It would, indeed, be easier to miss the proverbial plank than it would be to cite a writer in Lucian's age who does not inveigh against false philosophers."

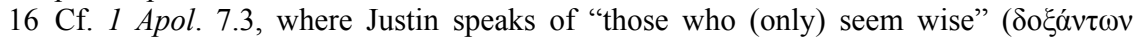
$\sigma о \varphi \tilde{\omega} v)$. The phrase is reminiscent of Aristotle's description of the activity of the sophist, namely, "to seem to be wise" ( 1.165a]). The "sophist" and the "false philosopher" were often conflated in the invective of this period, with both functioning as a counterpoint to true philosophy and thus receiving similar treatment.

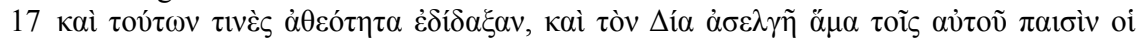

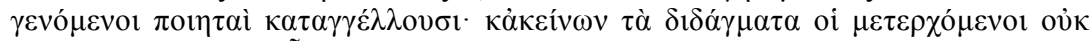

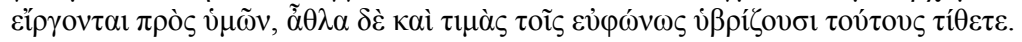

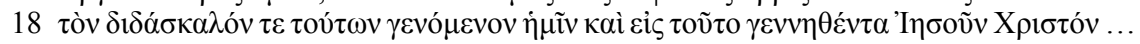

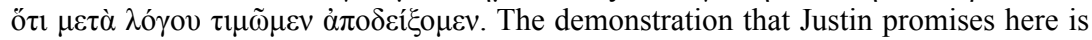
postponed in 1 Apol. 14.4: "In order that we might not seem to deceive you we considered it fitting, before the demonstration, to mention a few of the teachings of Christ himself. Let it be up to you, as powerful emperors, to examine if we have been taught these things and do ourselves teach them truthfully." Even though Justin distinguishes this section ("before the demonstration") from the demonstration (apodeixis) itself, the two are connected by their focus on Jesus in his role as teacher. 1 Apol. 13.3 promises proof that "we will demonstrate that we revere, on good grounds, Jesus Christ, who became the teacher of all these things to us" while 1 Apol. 14.4 announces an overview of the teachings $(\delta 1 \delta \alpha ́ \gamma \mu \alpha \tau \alpha)$ that "we have been taught and do ourselves teach"

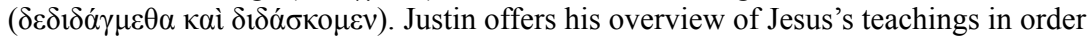
that "we might not seem to deceive you" (1 Apol. 14.4). This refers to Justin's claim lines earlier that under the influence of the Logos, "we withdrew ( $\dot{\alpha} \pi \dot{\varepsilon} \sigma \tau \eta \mu \varepsilon v)$ from (the demons)" (1 Apol. 14.1). Justin describes here how as a result of Jesus's influence the Christians live much more ethical lives (1 Apol. 14.2-3).

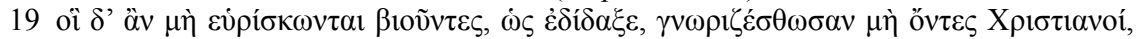

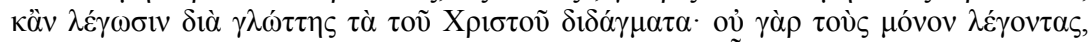

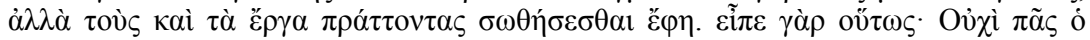

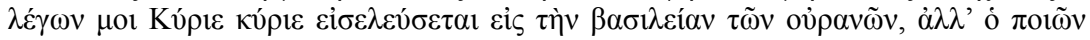

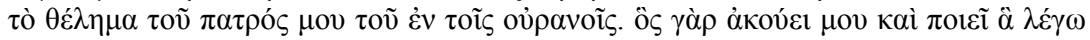

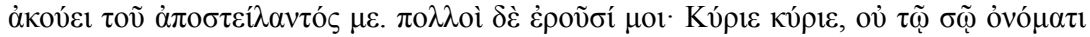

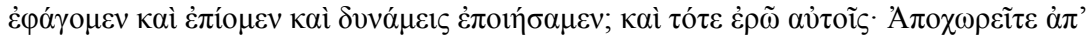

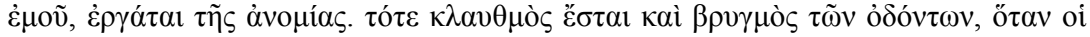

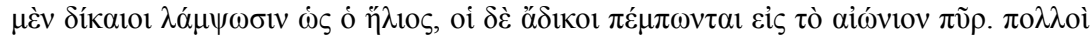




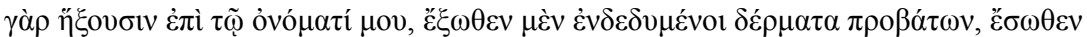

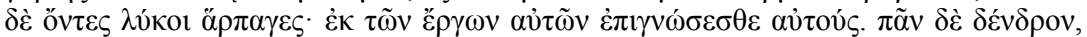

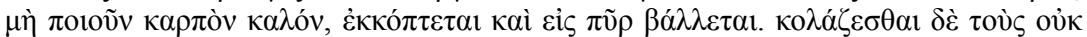

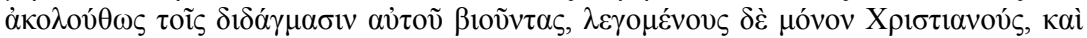
$\dot{v} \varphi$ ' $\mu \tilde{\omega} v \dot{\alpha} \xi 10 \tilde{u} \mu \varepsilon v$.

20 Requests for punishment and judicial action are common in petitions to the Roman government. See Ari Z. Bryen, Violence in Roman Egypt: A Study in Legal Interpretation, Empire and After (Philadelphia: University of Pennsylvania Press, 2013), esp. the petitions collected in Appendix B (pp. 214-79), many of which include a request for punishment. $1 \mathrm{Apol}$. differs from these petitions among other ways in that the request of punishment does not form the sum total of Justin's appeal to the authorities.

21 The crucially important twenty-sixth chapter appears as the third (26.1: Tpítov) in a

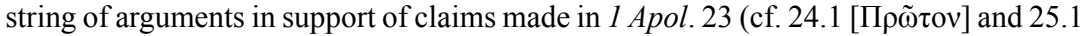
$[\Delta \varepsilon v i \tau \varepsilon \rho v]$ ). These three chapters (as well as the following three) must be understood as elaborations on $1 \mathrm{Apol}$. 23.3: "they (the demons) brought about the accusations against us of infamous and impious deeds, for which there is no witness or proof, and this we

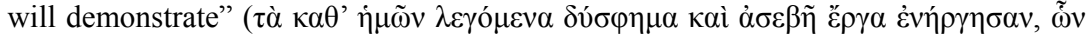

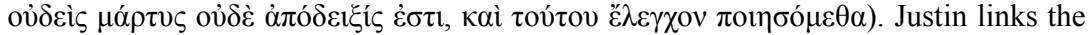
chapters that follow this statement to $1 \mathrm{Apol}$. 23.3 by means of thematic and verbal con-

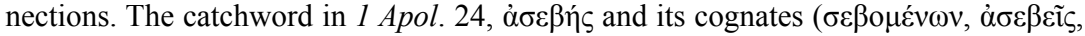

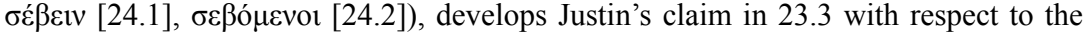
$\dot{\alpha} \sigma \varepsilon \beta \tilde{\eta} \tilde{\varepsilon} \rho \gamma \alpha$. Justin notes that different people worship different gods and that therefore

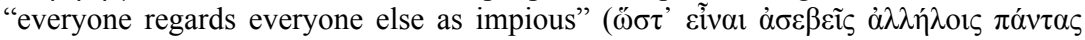
[24.1]). Impiety is an entirely subjective category and it is therefore impossible to offer a credible "witness" or "demonstration" that what the Christians do is impious (1 Apol. 23.3). Moreover, Justin hints, if anyone is to be considered $\alpha \sigma \varepsilon \beta \eta \dot{s}$ it should be those who worship "irrational animals" ( $\tau \tilde{\omega} v \dot{\alpha} \lambda \hat{\gamma} \gamma \omega v \zeta \dot{\omega} \omega v)$, not the Christians who follow the Logos and "say similar things to the Greeks" (1 Apol. 24.1). 1 Apol. 25 lacks direct verbal overlap with $1 \mathrm{Apol}$. 23.3, but a thematic connection is clearly present. In this passage Justin argues that the Christians have rejected gods who were involved in acts that are "shameful even to tell": Dionysus and Apollo with their pederastic exploits and Persephone and Aphrodite with their "sexual madness on account of Adonis." The Christians have turned to a passionless God (25.2), who was not subject to "insane passion" (oĩ $\sigma \tau \rho \varsigma)$ for men or women. It is hence preposterous to claim that Christians are involved in "infamous and impious deeds" (1 Apol. 23.3), which, as we learn in 1 Apol. 26, includes the "overturning of the lamp for unbridled sex." Again there is the clear suggestion that the Christians are less, not more ó $\sigma \varepsilon \beta \eta \dot{s}$ than their religious rivals. Justin rounds out this chapter by observing that the demons are the source of GrecoRoman myths (1 Apol. 25.3). This provides a direct connection to 1 Apol. 26, which begins with the assertion that "the demons put forth certain people."

22 These accusations are repeated in other sources. See, e.g., Athenagoras's Embassy, the body of which (3.1-36.2) consists of a defense against the charges of atheism, Thyestean banquets and Oedipean unions.

23 See Edward Champlin, Fronto and Antonine Rome (Cambridge, MA: Harvard University Press, 1980), 97-9. For Fronto's extensive correspondence with Antoninus Pius, Marcus Aurelius and Lucius Verus, see Michel P.J. van den Hout, ed., M. Cornelii Frontonis Epistulae, Bibliotheca scriptorum Graecorum et Romanorum Teubneriana (Leipzig: Teubner, 1988); Michel P.J. van den Hout, A Commentary on the Letters of M. Cornelius Fronto (Leiden; Boston: Brill, 1999).

24 Unfortunately, Minucius Felix does not indicate the date of Fronto's speech, but since he was appointed tutor shortly after Antoninus's rise to power in 138, there is a good chance this took place prior to the composition of $1 \mathrm{Apol}$. 


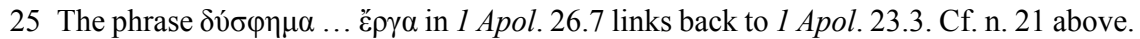

26 Assuming that Justin must have given an accurate account of Marcion's message, readers from antiquity to the most recent critical edition have corrected the text found in the manuscripts at this point. Eusebius and Minns-Parvis both offer versions that provide a more accurate description of Marcion's teaching. The reconstruction of Minns and Parvis is explicitly motivated by the inaccuracies in Justin's account of Marcion's teaching in the text of the MS and hence by the somewhat problematic assumption that Justin must have been accurate in his portrayal of Marcion: "The MS text gives the sense, 'and to confess that some other, as being greater, made greater things than this one'. But Marcion did not believe that his greater god created anything ... " (Justin, Philosopher and Martyr, 151 n. 4).

The following table gives the readings of the manuscripts, Eusebius and MinnsParvis respectively:

\begin{tabular}{|c|c|c|}
\hline$M S:$ & Eusebius: & Minns-Parvis: \\
\hline 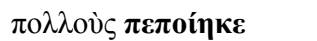 & 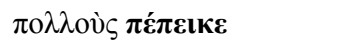 & 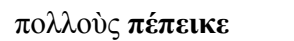 \\
\hline 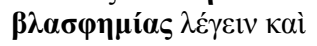 & 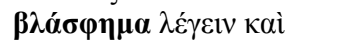 & $\beta \lambda \alpha \sigma \varphi \eta \mu i^{\alpha} \alpha{ }_{\varsigma} \lambda \varepsilon^{\prime} \gamma \varepsilon 1 v$ \\
\hline 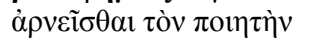 & 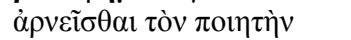 & 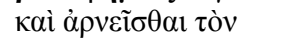 \\
\hline 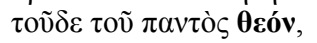 & 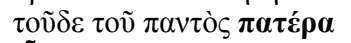 & $\pi \mathrm{o} \eta \tau \grave{\eta} \nu \tau 0 \tilde{v} \delta \varepsilon \tau \mathrm{ov}$ \\
\hline 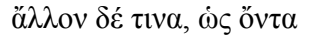 & 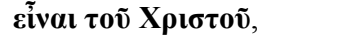 & $\pi \alpha v \tau$ đò $\boldsymbol{\theta \varepsilon o ́ v , ~} \alpha \lambda \lambda \lambda \mathrm{ov}$ \\
\hline 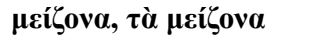 & 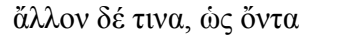 & 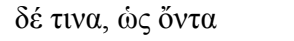 \\
\hline 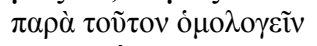 & 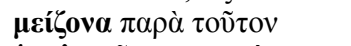 & $\mu \varepsilon \dot{c} \zeta o v \alpha \pi \rho \alpha \grave{\alpha} \tau o \tilde{\tau} \tau \nu$ \\
\hline$\pi \varepsilon \pi \mathrm{oi \eta \kappa \varepsilon ́v \alpha 1.}$ & 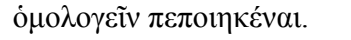 & 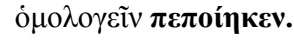 \\
\hline
\end{tabular}

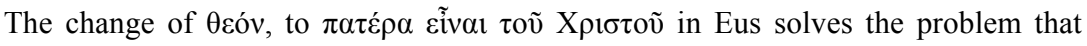
Marcion did not deny the existence of the Demiurge as such, but that he denied that the Demiurge was the Father of Jesus. The change signals that the scribe responsible assumed, like Minns and Parvis, that the text ought to accurately represent Marcion's teaching.

The presence of $\tau \grave{\alpha} \mu \varepsilon i \zeta{ }^{\prime} \sigma \alpha$ in the MS, but not in Eus, can be explained in various ways. It was dropped either due to haplography or in an attempt to correct the text's suggestion that Marcion's Supreme God created things. In the latter case the scribe

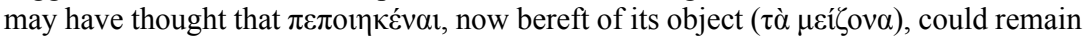
unaltered since it is possible to take it as an infinitive of purpose: "[Marcion] persuaded many to blaspheme and deny the Creator ... in order to make (them) confess another, greater than him." Since there are at least two plausible explanations for the omission of $\tau \grave{\alpha} \mu \varepsilon i \zeta o v \alpha$, it seems more likely that the words were indeed omitted rather than added. The reconstruction offered here is different from that suggested by Minns and Parvis, who propose that the original reading of the final word of the sentence was $\pi \varepsilon \pi$ oin (not attested in the manuscript tradition), and claim that "a misreading of an original finite verb followed by 'and' led to the infinitive followed by 'and."' Misreadings can happen at any time for any number of reasons, but it is not necessarily probable that a

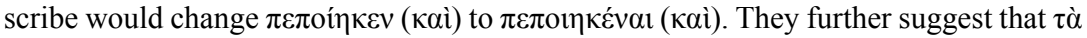
$\mu \varepsilon$ í $\mathrm{ov} \alpha$ was added to make sense of the infinitive, but as we have seen there is good reason to think that it was omitted rather than added, and the infinitive is not completely incomprehensible without $\tau \grave{\alpha} \mu \varepsilon i \zeta$ бov $\alpha$. Moreover, since the Eus text exhibits a tendency to bring the text into alignment with Marcion's teaching, the later addition of $\tau \grave{\alpha} \mu \varepsilon i \zeta o v \alpha$, which leads to the inaccurate description of Marcion's teaching as saying 
that the Supreme God created "greater things," is perhaps the less likely scenario. For all these reasons, I have decided to leave the MS text unaltered. The result is indeed a likely misrepresentation of Marcion's teaching, but it would have served Justin's rhetorical aims to depict Marcionite thought as muddled, obscure and inconsistent, which is exactly what the MS text suggests when it claims that Marcion denied the Maker of All, yet posited someone above him who made greater things than he. See $n$. 37 below for another example of deliberate mischaracterization of Marcion in this paragraph.

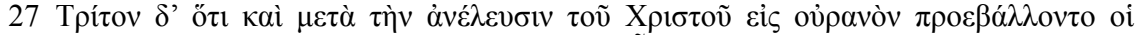

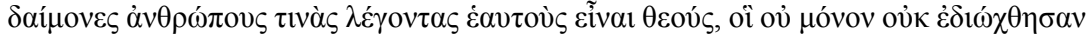

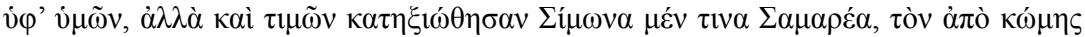

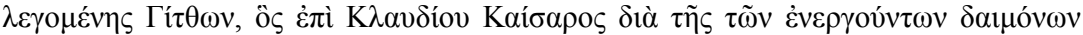

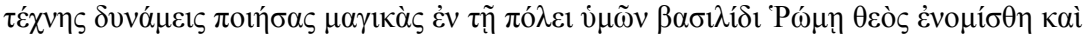

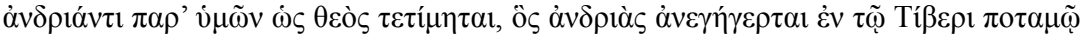

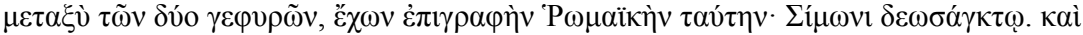

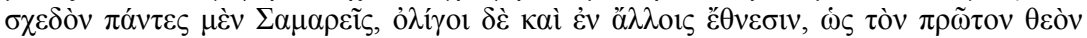
$\dot{\varepsilon} \kappa \varepsilon \tilde{1} v o v$ ó $\mu$ o

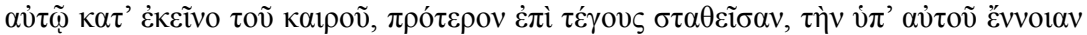

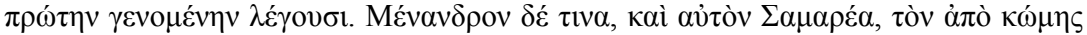

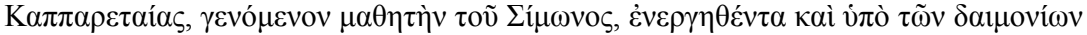

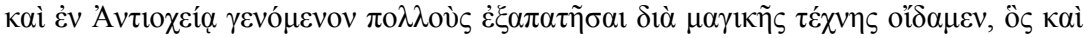

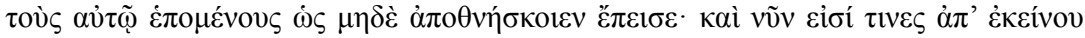

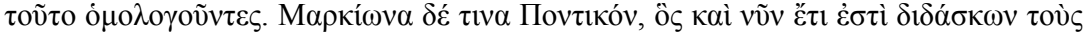

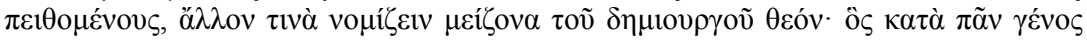

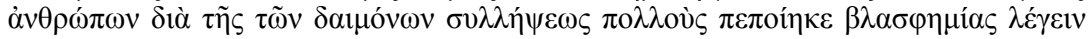

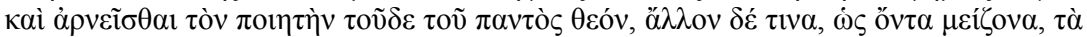

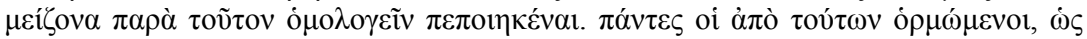

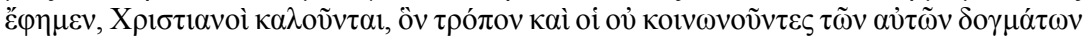

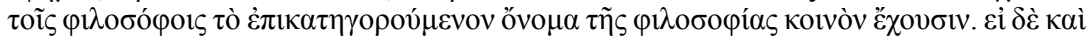

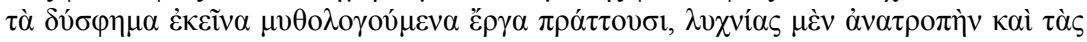

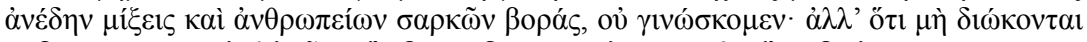

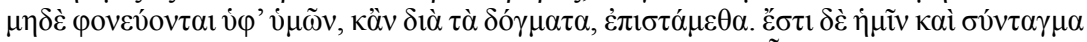

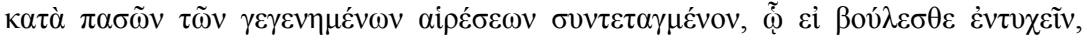
$\delta \omega ́ \sigma o \mu \varepsilon v$.

28 The forceful Christian response to Marcion suggests that Justin was not exaggerating entirely; Peter Lampe, From Paul to Valentinus: Christians at Rome in the First Two Centuries (Minneapolis, MN: Fortress Press, 2003), 250-1, summarizes the evidence: "A presbyter in Asia Minor and Hegesippus fought against Marcion's work, along with Dionysius of Corinth in a letter to Nicodemia. One also finds evidence of the battle against Marcion's work in Theophilus of Antioch, Philip of Gortyna in Crete, a certain Modestus, whose place of origin is unknown, Irenaeus of Lyon, and perhaps, Melito of Sardis. In Rome in the second century Rhodon writes against the Marcionites, and in Alexandria, Clement. Celsus is also aware of the Marcionite church. There are also 'several others' (Eusebius, Ecc. Hist. 4.25) who fight against Marcion. At the turn of the century, Tertullian (Adv. Marc. 5.19) correctly observes: 'Marcion's heretical tradition filled the whole world' (Marcionis traditio haeretica totum implevit mundum)."

29 Cf., e.g., Ibid., 250: "Justin names Marcion along with the traditional archheretics Simon and Menander ..."

30 Cf., e.g., Hervé Inglebert, Interpretatio christiana: Les mutations des savoirs (cosmographie, géographie, ethnographie, histoire) dans l'antiquité chrétienne (30-630 après J.C.) (Paris: Institut d'études augustiniennes, 2001), 418: "Pour Justin et Irénée, les hérésies chrétiennes commençaient avec Simon le Mage, et donc après le Christ. Cette affirmation permettait de relier les gnostiques, leurs adversaires contemporains, 
avec des passages scripturaires néotestamentaires qui en réalité ne les concernaient nullement." Kendra Eshleman, The Social World of Intellectuals in the Roman Empire: Sophists, Philosophers, and Christians, Greek Culture in the Roman World (Cambridge: Cambridge University Press, 2012), 217: "Simon Magus ... enjoyed a vibrant career as the father of false belief after Justin cast him in that role. His tantalizingly vague appearance in the canonical Acts made him well suited for the part."

31 I largely concur with Barnard, The First and Second Apologies, 136: "While it is clear that the inscription originally had no connection with Simon Magus, it is not impossible that Simonians in Rome in the second century used it in their own cultus. We know that this cult was regularly performed before statues of Zeus and the similarity of the names Semoni and Simoni would have been thought significant by such allegorizers. There are plenty of examples of temples and images used by different sects for the performance of their own cults (see Ps. Lucian, De Dea, 11-13; and cf. also Plutarch's reference [De Supers. 167d] to the superstitious person worshiping statues of bronze or wood or wax). Justin's information may therefore have a historical basis in the performance of the Simonian cult by his followers in connection with this statue." Similarly, Le Boulluec, La notion d'hérésie, 82; Mark J. Edwards, "Simon Magus, the Bad Samaritan," in Portraits: Biographical Representation in the Greek and Latin Literature of the Roman Empire, ed. Mark J. Edwards and Simon Swain (Oxford: Clarendon Press, 1997), 74.

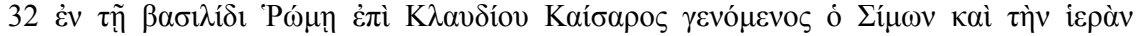

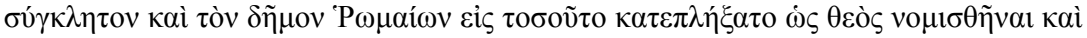
$\dot{\alpha} v \delta \rho t \alpha ́ v \tau 1 \ldots \tau \imath \mu \eta \theta \tilde{\eta} v \alpha 1$

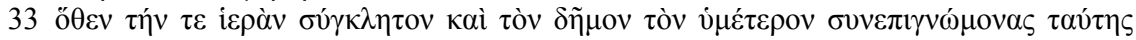

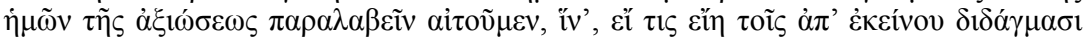

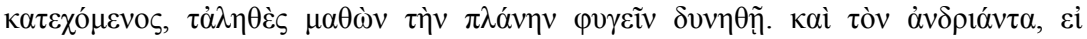
$\beta$ ои́ $\lambda \varepsilon \sigma \theta \varepsilon, \kappa \alpha \theta \alpha 1 \rho \eta ́ \sigma \alpha \tau \varepsilon$.

34 Pace, e.g., Richard Adelbert Lipsius, Zur Quellenkritik des Epiphanios (Wien: W. Braumüller, 1865), 57: "Bekanntlich hat sich Justin, welcher diese angebliche Simonssäule selbst gesehn, durch die von ihm falsch gedeutete Inschrift derselben täuschen lassen ..."

35 Justin's Samarian provenance suggests that he may well have been a reliable source on (traditions about) Simon and Menander who, as Justin notes, also came from Samaria (1 Apol. 26.2, 4). Interestingly, however, Justin does not present himself in this passage as an authority on the matter because of his Samarian background. In fact, he does not identify himself as a Samarian at all in 1 Apol. (contrast Dial. 120.6). He states that he hails from Flavia Neapolis in Syria Palaestina in 1 Apol. 1.1, but he could hardly have expected his audience to not only recall the fact at this point in the text, but to also realize that Flavia Neapolis was in the same region as the towns from which Simon and Menander hailed. Attentive readers might have made this connection, but if Justin intended to derive rhetorical benefit from their common origin he would have made their shared background more obvious. More likely, the reason why Justin mentions these place names (Gittha and Capparetaea, on which see Adolf von Harnack, Zur Quellenkritik der Geschichte des Gnosticismus [Leipzig: E. Bidder, 1873], 83-4; cf. also Clemens Scholten, "Zum Herkunftsort des Simon Magus," VC 69 [2015]: 534-41) was to suggest that Simon and Menander hailed from the fringes of

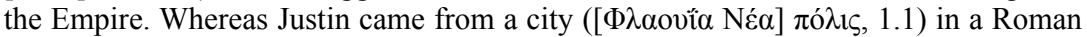
province (Syria Palaestina), Simon and Menander came from villages ( $\kappa \omega ́ \mu \eta, 26.2$; 26.4) in Samaria. Similarly, Justin does not mention that Marcion came from Sinope (assuming he knew that tradition), which was a Roman colony, but described him as Pontic (Поvтıкós, 26.5). The reason for this may have been that Justin wanted to present his opponents as provincials from the backwaters of the empire. In the case of Marcion, referring to him as "Pontic" also activated a range of traditional prejudices against the inhabitants of that region (cf. Tertullian, A.M. 1.1). 
Beatrice Cherubini, "Remarques sur le personnage Marcion dans l'interprétation de

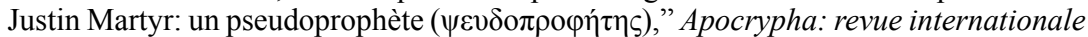
des littératures apocryphes 22 (2011): 248, suggests that Pontus is mentioned as part of Justin's efforts to depict Marcion as a false prophet, since false prophets are regularly associated with the North in biblical tradition. This is far-fetched. Pontus was not the northernmost region of the empire and one would expect Justin to have drawn attention to the relatively northern position of Pontus if he wanted his audience to establish a link with the false prophet tradition and even then, one wonders if his readers could have made the connection.

36 1 Apol. 29.4 about Antinous being worshiped as a god, which is clearly out of place in its present position and fits much better with 1 Apol. 26, may be a gloss specifically intended to address the problem that only Simon matches the claim of 1 Apol. 26.1 that "the demons put forth certain people who were saying that they themselves were gods." The passage may have ended up in its present position because both 1 Apol. 29.1-3 and 29.4 deal with originally Egyptian phenomena.

37 Minns and Parvis, Justin, Philosopher and Martyr, 149 n. 9, write: "The whole section referring to Marcion seems out of place here, since Justin has undertaken to give examples of human beings who claim that they are gods ... Marcion, however, does not fit the argument at all, and the reference to him may have been triggered by the reference to the two other heretics. The passage may be drawn from Justin's own Syntagma, or the addition of Marcion may have been made in a subsequent edition of the Apology intended primarily for a Christian readership." But rather than explain it as the result of confusion, corruption or later addition, could the passage not simply be read as intentionally unfair? Justin was unconcerned about giving his opponent a fair hearing; that much is evident from his statement immediately following his remarks about Marcion that he "does not know" whether "they do those shameful things about which rumors have been going around, 'throwing down the lamp,' shameless intercourse and consuming human flesh" (26.7). Marcion was acknowledged by his more generous critics to be an ascetic and Justin's insinuations are almost certainly without any basis in fact (cf., e.g., Williams, Rethinking “Gnosticism," 26). I propose that along the same lines, Justin is making a deliberate rhetorical move when he implies that Marcion proclaimed himself a god.

Justin's rhetoric in fact suggests that Marcion saw himself as the First God. The chapter commences with the claim that the demons "put forth certain people who said that they themselves were gods." Unless one already has prior knowledge of Marcion's teaching it would be natural to understand Justin to be saying that Marcion referred to himself when speaking of "another God." The other, greater god proclaimed by Marcion must refer to Marcion himself, given that he is one of the people ( $\tau$ ívas) who "say that they themselves were gods." Justin deliberately allows this suggestion, I propose, to further diminish Marcion's person and teachings. Marcion's alleged proclamation of himself as the highest God would likely have been ludicrous to Justin's audience. Claims of divinity could be made about members of the imperial family, especially after their earthly lives had drawn to a close (cf. 1 Apol. 55.7), but hardly about a marginal teacher from the barbarian backwater of Pontus. That Marcion allegedly proclaimed himself a god was offensive, the claim to be the Supreme God patently absurd. Justin's rhetoric, then, sought to reduce Marcion to a laughable caricature.

It is worth noting in this connection that Justin's imperial audience seems to have been moderate in their advancement of the ruler cult and was reluctant to regard even their own family members as divine. See Barbara Burrell, Neokoroi: Greek Cities and Roman Emperors, Cincinnati Classical Studies, new ser., v. 9 (Leiden; Boston: Brill, 2004), 84-6, 364. Glen Bowersock notes that Marcus Aurelius in his Meditations "nowhere suggests that he is himself divine or, for that matter, will be after his death ... There is no hope here in either being or becoming divus ... The notion of himself as a 
real god or of his predecessors as gods simply seems not to have entered his thinking." (Glen W. Bowersock, "Greek Intellectuals and the Imperial Cult in the Second Century A.D.," in Le culte des souverains dans l'Empire Romain. 7 exposés suivis de discussions, ed. E.J. Bickerman and W. den Boer [Vandœuvres-Genève: Fondation Hardt; Dépositaire pour la Suisse: Francke, Berne, 1973], 186). Commodus, by contrast, who was only just becoming a public figure around the time that Justin wrote 1 Apol. (Minns and Parvis, Justin, Philosopher and Martyr, 38), would later present himself as Hercules (Cassius Dio, Ep. 73.15.2-16.1; Historia Augusta, Commodus 8.9, 9.2).

38 On Justin's familiarity with (Middle) Platonism, see, most recently, Runar M. Thorsteinsson, "By Philosophy Alone: Reassessing Justin's Christianity and His Turn from Platonism," EC 3 (2012): 492-517, esp. 507 n. 37. Cf. also n. 43 below.

39 His work has often been ascribed to the Platonist Albinus, but the manuscript tradition gives Alcinous, who may or may not be the same person as a Stoic philosopher by that name. Whatever the case, the Didaskalikos evinces the strong cross-fertilization of Stoic and Platonic (as well as Peripatetic) traditions during this time. See John Whittaker, "Platonic Philosophy in the Early Centuries of the Empire," in $A N R W$, vol. 2.36.1 (Berlin: Walter de Gruyter, 1987), 81-123 and Gretchen J. Reydams-Schils, Demiurge and Providence: Stoic and Platonist Readings of Plato's Timaeus, Monothéismes et Philosophie (Turnhout: Brepols, 1999), 189-205.

40 Handbook of Platonism 10.3. Tr. John M. Dillon, Alcinous: The Handbook of Platonism (Oxford: Clarendon Press, 1995). Greek text according to Pierre Louis, Albinos

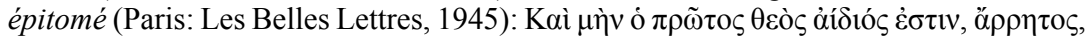

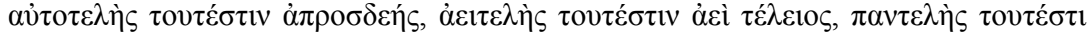

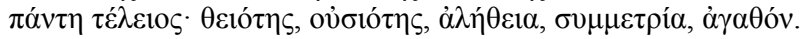

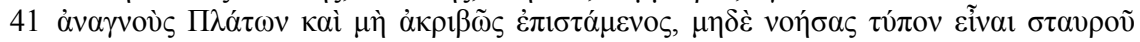

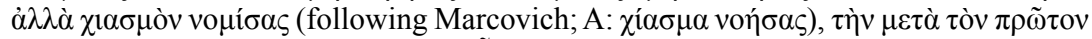

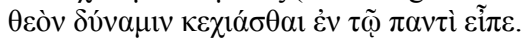

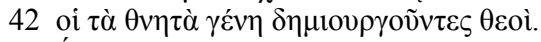

43 Édouard des Places, "Platonisme moyen et apologétique chrétienne au IIe siècle ap. J.-C.: Numenius, Atticus, Justin," SP 15 (1984): 435, notes that it is chronologically possible that Numénius influenced Justin. Arthur J. Droge, Homer or Moses? Early Christian Interpretations of the History of Culture, HUTh 26 (Tübingen: Mohr Siebeck, 1989), 72 n. 87, writes: "Perhaps it is Numenius to whom Justin refers when he says that he studied with a philosopher who held 'a high position among the Platonists' (Dial. 2.6). Like Justin, Numenius also came from the East: Apamea in Syria." But cf. Mark J. Edwards, "On the Platonic Schooling of Justin Martyr," JTS 42 (1991): 22: "We do not know where Justin studied or where Numenius taught; we do not even know whether either of them antedated the other" (similarly, 30-31). Nevertheless, Edwards notes that "Justin stands in that line [of Platonism] which can be traced back from Plotinus through his most famous and important predecessor, Numenius of Apamea" (21).

44 Greek text from Édouard des Places, ed., Numénius: Fragments (Paris: Les Belles

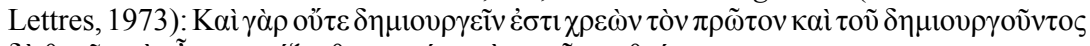

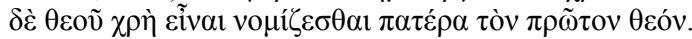

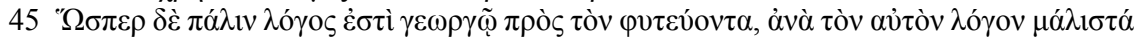

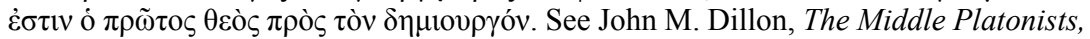
80 B.C. to A.D. 220 (Ithaca, NY: Cornell University Press, 1977), $368 \mathrm{n} .1$ on the textual difficulties of this passage.

46 Philo in Migr. 194 describes the cosmos as the creature $(\delta \eta \mu$ เoú $\rho \gamma \mu \alpha)$ of the "First God," and in Migr. 181 seems to identify the First God with the Demiurge (cf. also Abr. 75). This makes sense from Philo's biblical perspective, but it was probably not what the emperors and a more general Greco-Roman audience would have thought when they read "First God" in the second century CE. 
47 Note also that in Dial. 120.6, Justin refers to Simon as the one whom the Samarians consider "god above every principality, authority and power."

48 Greek text preserved in Hippolytus, Elenchos 7.33 and 10.21.

49 Unless otherwise noted, I will follow the fine translation of $A$.H. by Dominic J. Unger (books 1 and 2) and Matthew C. Steenberg (book 3) published in the Ancient Christian Writers, series (New York: Paulist Press, 1992).

50 In later traditions Simon likewise resembles Marcion to a significant degree, especially in the Pseudo-Clementines. See Hans Joachim Schoeps, Jewish Christianity: Factional Disputes in the Early Church (Philadelphia: Fortress Press, 1969), 16; Hajo U. Meyboom, "Marcion en Paulus in de Clementijnen," Theologisch Tijdschrift 25 (1891): 1-46; A. Salles, "Simon le Magicien ou Marcion?," VC 12 (1958): 197-224; Frédéric Manns, "Les Pseudo-Clémentines ('Homélies' et 'Reconnaissances'): état de la question," Liber Annuus 53 (2003): 175. Cf. Karl Shuve, "The Doctrine of the False Pericopes and Other Late Antique Approaches to the Problem of Scripture's Unity," in Nouvelles intrigues pseudo-clementines = Plots in the Pseudo-Clementine romance: actes du deuxième colloque international sur la litterature apocryphe chrétienne, Lausanne-Genève, 30 août-2 septembre 2006, ed. Frédéric Amsler et al. (Prahins: Éditions du Zèbre, 2008), 441; Han J.W. Drijvers, "Adam and the True Prophet in the Pseudo-Clemetines," in Loyalitätskonflikte in der Religionsgeschichte: Festschrift für Carsten Colpe, ed. Christoph Elsas and Hans Gerhard Kippenberg (Würzburg: Königshausen und Neumann, 1990), 320; Donald H. Carlson, Jewish-Christian Interpretation of the Pentateuch in the Pseudo-Clementines (Minneapolis, MN: Fortress Press, 2013). According to Irenaeus's description of Simon, he, like Marcion, rejected the prophetic writings and drew on Pauline traditions (specifically the Pauline language of salvation by grace rather than works [Eph 2:8-9, cf. Gal 2:16, Rom 3:28]): "Moreover, the prophets uttered their predictions under the inspiration of those angels who formed the world; for which reason those who place their trust in him and Helena no longer regarded them, but, as being free, live as they please; for men are saved through his grace, and not on account of their own righteous works (secundum enim ipsius gratiam saluari homines, sed non secundum operas iustas)" (A.H. 1.23.3). Fragment 13, preserved in Hippolytus, Elenchos 6.19 gives $\chi \alpha$ ó $1 \varsigma$ where the Latin has gratia; it breaks off before the final part of the sentence, but it is a safe assumption that opera translates the Pauline word čp $\alpha$.

51 Cf. 1 Apol. 8.2: "we pursue the way of life that is with God the Father and Demiurge

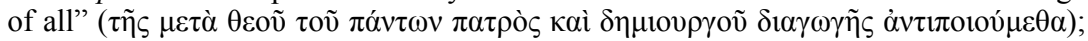
$1 \mathrm{Apol}$. 10.2 "we have been taught that, being good, he created all things in the begin-

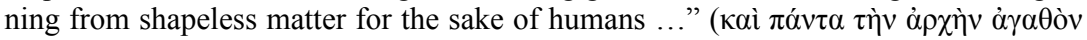

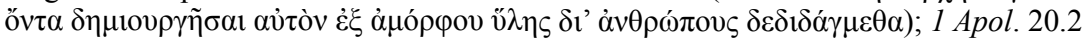
"we reckon that God the Maker of all things is superior to what is subject to change"

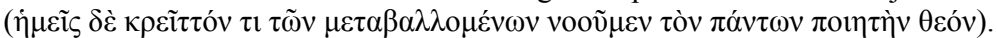

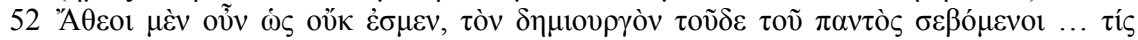

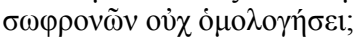

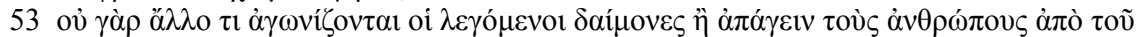

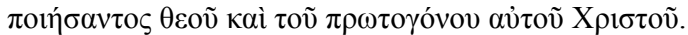

54 Heraclitus and certain unnamed others were also "called atheists" even though they lived according to the Logos (1 Apol. 46.3).

55 The passage is puzzling enough that Minns and Parvis, Justin, Philosopher and Martyr, $153 \mathrm{n}$. 1, suggest that it "is more readily understood if it is a later addition to the Apology whose primary audience was orthodox Christians being provided with reasons for disdaining the heretics - even if it could be shown that they had been 'martyred."'

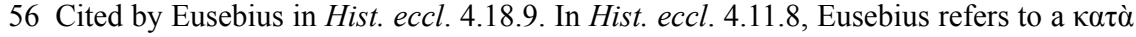

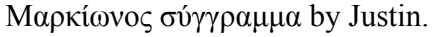




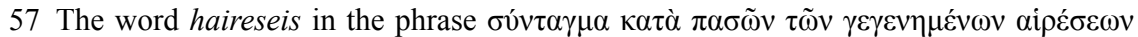

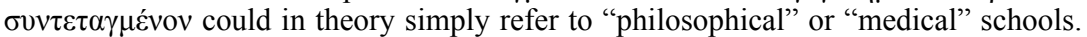
However, the context in which it appears and the construction with kata+gen. (usually: "against") suggest that the Syntagma was not a neutral overview of "all" the various philosophical and/or medical schools, but a treatise written specifically against (socalled) Christian schools of thought that Justin rejected (i.e., against "heresies").

58 Matthijs den Dulk, "Justin Martyr and the Authorship of the Earliest Anti-Heretical Treatise," $V C$ (forthcoming).

59 E.g., Prigent, Justin et l'Ancien testament.

60 In the Dialogue Simon appears only in passing in 120.6. Adelbert Davids, "Justin Martyr on Monotheism and Heresy," Nederlands archief voor kerkgeschiedenis 56 (1975): 223, argues that Simon is in view in Dial. 77.2 as well.

61 To the best of my knowledge, this possibility was first suggested by Richard Adelbert Lipsius, "Ueber die ophitischen Systeme," Zeitschrift für wissenschaftliche Theologie 6 (1863): 410-56.

62 Similarly, Lipsius, Zur Quellenkritik des Epiphanios, 61; Harnack, Zur Quellenkritik der Geschichte des Gnosticismus, 46; Walter Bauer, Orthodoxy and Heresy in Earliest Christianity (Philadelphia: Fortress Press, 1979), 280-1; Gerd Lüdemann, Heretics: The Other Side of Early Christianity (Louisville, KY: Westminster John Knox Press, 1996), 19; Sakari Häkkinen, "Ebionites," in A Companion to Second-Century Christian "Heretics," ed. Antti Marjanen and Petri Luomanen (Leiden; Boston: Brill, 2005), 249; Smith, Guilt by Association, 178-9. On Justin's attitude toward such believers, see below, pp. 103-105.

63 Hegesippus, whose list includes all of the "heresies" mentioned by Justin, also does not list the Ebionites and Nicolaitans (as noted by Harnack, Zur Quellenkritik der Geschichte des Gnosticismus, 38; Lüdemann, Heretics, 19; Smith, Guilt by Association, 180).

64 Geoffrey Smith argues that all three entries were added by one or multiple anonymous authors who edited Justin's Syntagma (Guilt by Association, 133-45). I am skeptical. See my review essay on Smith's monograph in EC 7 (2016): 549-59.

65 Simone Pétrement, A Separate God: The Origins and Teachings of Gnosticism (San Francisco: Harper, 1993), 300-3, suggests that Cerinthus did not propound a clearly demiurgical theology, but at least to Irenaeus's mind he evidently did (A.H. 1.26.1).

66 Justin introduces this text as directed against haireseis, a term normally used for philosophical schools, which also suggests a connection with the so-called Christians who resemble "false philosophers" of 1 Apol. 26.6.

67 This does not of course mean that all contemporary groups espousing a form of demiurgism were necessarily included in Justin's Syntagma. The Valentinians, Basilideans and Saturnilians are mentioned in the Dialogue (35.6), and they are therefore among the primary candidates for inclusion in the Syntagma. It cannot be concluded from the fact that the Valentinians, Basilideans and Saturnilians are mentioned in the Dialogue, but not in $1 \mathrm{Apol}$., that Justin did not yet think of them as "heretics." The question of whether Justin regarded them as heretics at this time is further complicated by the very limited reliable information we have about these groups and the figures that (allegedly) founded them. See, e.g., Christoph Markschies, Valentinus Gnosticus?: Untersuchungen zur valentinianischen Gnosis mit einem Kommentar zu den Fragmenten Valentins, WUNT 65 (Tübingen: Mohr Siebeck, 1992); Winrich A. Löhr, Basilides und seine Schule. Eine Studie zur Theologie- und Kirchengeschichte des zweiten Jahrhunderts, WUNT 83 (Tübingen: Mohr Siebeck, 1996). The shift that Markschies identifies between the historical Valentinus and the Valentinians may have led to a development in Justin's evaluation of this group, but this can be no more than speculation. On a related note, it is possible that the Ptolemy whom Justin names in 2 Apol. is the same person as the Valentinian Ptolemy mentioned by Irenaeus in A.H. and as the author of the Epistula ad 
Floram (see, e.g., Christoph Markschies, "New Research on Ptolemaeus Gnosticus," ZAC 4 [2000]: 246-9; Daniel Wanke, "Irenäus und die Häretiker in Rom," ZAC 3 [1999]: 202-40). If so, Justin refers to him without giving any indication that he disapproves of his Valentinian ideas. This may, however, be explained simply by considerations of expediency and need not necessarily imply that Justin changed his mind about Valentinus or the Valentinians in the time between writing the Apologies and Dial. (similarly, e.g., Ismo Dunderberg, Beyond Gnosticism: Myth, Lifestyle, and Society in the School of Valentinus [New York: Columbia University Press, 2008], 91-2). Whether Carpocrates, Cerinthus and Cerdo were mentioned in the Syntagma is uncertain. Carpocrates appears in an excerpt from Hegesippus (Eusebius, Hist. eccl. 4.22.5), which perhaps suggests that Irenaeus and Hegesippus took his name from the Syntagma. Cerinthus and Cerdo are not mentioned on Hegesippus's list, which may imply that Justin did not mention them in his Syntagma, on the assumption that otherwise Hegesippus would have listed them as well. The accuracy of this assumption is contestable, however. Cf. Harnack, Zur Quellenkritik der Geschichte des Gnosticismus, 46.

68 The centrality of demiurgism to Justin is also reflected on the pages of his Martyrdom. In response to the prefect's question to explain his doctrine $(\delta o ́ \gamma \mu \alpha)$, the first thing Justin mentions is that "we regard Him [the God of the Christians] alone as the Demiurge

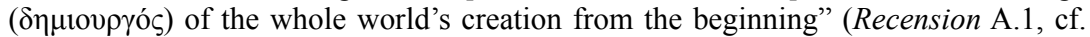
B.2), thus drawing a sharp contrast with anyone who would separate the Demiurge and the True God. 


\section{THE CASE FOR AN INTERNAL AUDIENCE}

It is difficult to think of anyone more influential in the study of early Christianity than Adolf von Harnack. His contributions on a mindboggling range of topics have set the agenda in various areas of study for generations. Even when Harnack is wrong, as at points subsequent scholarship has inevitably shown him to be, he is always interesting. His comments on the audience of the Dialogue are no exception. The dominant paradigm of scholarship on this question was established by Harnack for decades in a few quick, insightful comments. ${ }^{1}$ Drawing in part on earlier work by Franz Overbeck, Harnack claimed that Justin had "pagans" in mind when he wrote the Dialogue. ${ }^{2}$ This was a revisionist idea at the time. For centuries, the Dialogue had been read as an evangelistic tractate directed at Jews, but late nineteenth- and early twentieth-century German scholarship upended this view along with much other received wisdom about the first Christian centuries.

It has taken scholars some time to be able to look beyond the authority of Harnack and his distinguished contemporaries, and to reconsider the relevant evidence on its own terms. In this instance, the outcome of this process has not been particularly favorable to Harnack. A number of the arguments initially advanced in favor of the "pagan hypothesis" operated on the problematic assumption that Judaism and Hellenism were neatly separable entities. For instance, the philosophical prologue (Dial. 1-9) was regarded as of interest only to pagans and not to Jews, since philosophy was seen as essentially the sole prerogative of pagans. ${ }^{3}$ And if the introductory chapters were written for pagans, the same was thought to necessarily be true of the rest of the Dialogue. Given the degree to which Hellenism and Judaism were intertwined in this period - something that has only been fully appreciated in recent decades - such arguments no longer convince. Jews were very much part of the Greco-Roman world and some of them were highly educated literati with a deep interest in contemporary philosophy. Indeed, in the Dialogue itself, Justin's Jewish interlocutor Trypho claims that he was "taught by Corinthus, the Socratic philosopher" (Dial. 1.2).

The "pagan hypothesis" faces other weaknesses as well. Many of these have been engaged at length elsewhere, so I will restrict myself here to two points that I contend have not been sufficiently critically analyzed. ${ }^{4}$ These are important to discuss, since despite their prominence in the scholarly debate they are both 
problematic. They cannot be used in to support the "pagan hypothesis," but they also cannot support any other theory about the Dialogue's audience.

\section{Marcus Pompeius}

The first concerns the identity of Marcus Pompeius, who is mentioned towards the very end of the Dialogue: "Having said these things, my dearest Marcus Pompeius, I concluded" (Dial. 141.5 [cf. 8.3]). ${ }^{5}$ Because of his Roman name, Pompeius has been labeled a "pagan." And on that basis, scholars have concluded that the Dialogue's audience must likewise have consisted of such pagans. ${ }^{6}$ This argument again problematically assumes a significant divide between the Greco-Roman and the Jewish and Christian matrices. More recently, scholars have correctly pointed out that given the widespread adoption of Greek and Latin names among Jews it is precarious to determine on the basis of a name alone whether someone is a "pagan" or a Jew (never mind a Christian). ${ }^{7}$ I would add that there is in principle nothing to exclude the possibility that Marcus Pompeius was a freedman who received his nomen and possibly also his praenomen from his Roman patron, which renders it even more troublesome to try to determine his identity solely on the basis of his name. ${ }^{8}$ Moreover, scholars have often assumed that Pompeius's identity and that of the audience of the Dialogue must be identical. But this is not necessarily the case. Rather than the addressee, Pompeius is perhaps better thought of as the dedicatee. $\mathrm{He}$ is not consistently addressed by Justin, but receives only a fleeting mention at the end of the Dialogue, which suggests that he may have been the dedicatee and, perhaps, that he acted as Justin's literary patron. ${ }^{9}$ Comparison with Josephus's Jewish Antiquities is instructive on this point. Josephus too addresses his patron directly only at the end of his work: "Having now given you a full account of our ancient history, most excellent Epaphroditus, I now bring, for the present, my discourse to a close" (Vita 430)..$^{10}$ It is possible that a dedicatee gave an author specific instructions regarding literary productions. But this does not mean that the composition necessarily addressed his own personal questions or existential concerns. It might simply have been something that the dedicatee considered a worthwhile project. ${ }^{11}$ If Marcus Pompeius was indeed Justin's patron and supported the production of the Dialogue, he must have already been convinced of the value of Justin's teachings, which perhaps suggests that he was a Christian. In any case, the name "Marcus Pompeius" is of little use in the quest for the audience of the Dialogue. Not only is it unclear that the text was intended to address Pompeius's personal questions, the name itself does not allow us to say with certainty whether he was a Jew and/ or a Christian, or neither, and it certainly cannot tell us much of anything about the audience beyond this single individual.

\section{Trypho's companions}

A second problematic piece of evidence concerns the identity of Trypho's companions. Advocates of the "pagan hypothesis" have argued that Trypho's friends 
were pagans and that the audience of the Dialogue therefore also consisted of pagans. The question of the identity of Trypho's companions is important and significant (in my view, they are probably Jewish, like Trypho) ${ }^{12}$ but what is surprising is that this question has received so much attention from those arguing in favor as well as those arguing against the "pagan hypothesis." After all, the idea that the identity of the interlocutors is the same as the identity of the audience is little more than a doubtful supposition. And yet, the claim that Trypho's companions represent the readers is made time and again in the scholarly literature, though evidence in its support is lacking. Ultimately, there is no good reason to think that the identity of Trypho's friends and that of the Dialogue's audience must be the same. It is, moreover, remarkable that the Jewish identity of the main interlocutor (Trypho) could be so easily ignored by proponents of the "pagan hypothesis." If the audience within the text equals the audience of the text, then why not assume that it was addressed to Jews like Trypho (or at least also to Jews like Trypho)? In sum, the question of the identity of Trypho's friends, important as it is as an interpretive question, cannot be decisive in connection to the debate about the Dialogue's audience.

\section{Alternative theories}

Having rejected the "pagan" theory, a number of recent scholars have considered alternative hypotheses. Some have posited a Christian audience, in keeping with a broader tendency in scholarship to see ancient apologetic literature as intended primarily for internal consumption..$^{13}$ There is also a strong scholarly tradition, especially among those who have published specialized monographs on the Dialogue, to return to (a modified version of) the old view that the Dialogue was written primarily for a Jewish audience. ${ }^{14}$ Before considering the arguments pro and contra, I would like to briefly draw attention to the essentialism that has characterized the scholarly discussion thus far. Even when allowance is made for the possibility of multiple overlapping audiences, these are still usually framed as "Jews," "Christians," and "pagans," with little recognition of the essentially subjective nature of such labels in the mid-second century. This may be due in part to the rhetoric of the Dialogue, which masks various degrees of overlap and porosity in the service of an ideal projection of what Christians, Jews, and others should look like. At the same time, however, even within the Dialogue such negotiations do come to the fore explicitly. For instance, Justin debates if one can keep the Jewish laws and still remain a Christian in Dial. 46-47, and he refers multiple times to people who claim to be Christian, but in his view are not (see especially Chapter 5). ${ }^{15}$ Clearly, "Jew(ish)" and "Christian" were by no means stable concepts with obvious, universally agreed-upon boundaries. Justin advocates a particular understanding of these labels, but this should not be confused with social description. ${ }^{16}$ Put simply, what Justin understood such labels to entail would not have been shared, certainly not immediately and unambiguously, by others who populated the Jewish and Christian world(s) of the second century. This has concrete 
implications for the question of audience. Even if Justin somehow managed to address only those people whom he considered to belong to one group and not the other (on the practical difficulties this entailed, see below), his judgment would by no means have been universally shared. Referring to Justin's primary and secondary audience, as some scholars do, alleviates some of these difficulties, but still implies that such audiences were in principle neatly distinguishable. The reality was much murkier, and variously perceived by the ancient actors themselves. The failure to adequately acknowledge this reality is symptomatic of a broader tendency to limit analysis of the Dialogue to the literary and rhetorical level with little apparent awareness of, or reference to, the complex realities of the second-century world that Justin and his readers inhabited.

With this in mind we return to the arguments that have been advanced in favor of a Jewish or Christian audience for the Dialogue. The case for the former rests to a significant degree on the work of Theodore Stylianopoulos. Although he admits that the Dialogue was "written within and also for the Christian community at large, and [was] thus automatically ... directed to the attention of Christian readers and of all those who claimed to be Christians, ${ }^{17}$ he argues that the Dialogue is primarily addressing Jews. ${ }^{18}$ Stylianopoulos offers a variety of arguments that point in the direction of a Jewish or Christian (but not a pagan) audience, many of them based on comparison of the Dialogue with $1 \mathrm{Apol}$., a document in which Justin did address a broader Greco-Roman audience. Stylianopoulos's "strongest evidence" for specifically identifying Jews, rather than Christians, as the primary addressees of the Dialogue consists of four passages in which Justin refers to "the eschatological remnant" among the Jews that will be saved (Dial. 25.1, 32.2, $55.3,64.2-3) .{ }^{19}$ This forms the theological basis for Justin's consistent appeals to Trypho and his friends to convert (e.g., Dial. 8.2, 28.2, 35.8, 96.3, 137.1, 142.2). Stylianopoulos argues that Justin is not interested in simply demonstrating the superiority of Christianity but that he holds out hope that his Jewish interlocutors will actually be convinced by his Christian message. Stylianopoulos contends that the Dialogue was intended as a contribution to this missionary endeavor. ${ }^{20}$

This line of argument has convinced a good number of scholars and certainly has considerable force, but I do not think that it necessarily requires a primarily Jewish audience. As I will argue in Chapter 4, it is possible to understand Justin's urge to convert Trypho and other Jews as meaningful within the context of internal Christian debate as well. The reading developed in that chapter will also be able to integrate Justin's many harsh comments toward Trypho and Jews more generally, which undercut Stylianopoulos's argument that Justin was primarily interested in converting a Jewish audience. These harsh anti-Jewish passages, which will be discussed in greater detail in Chapter 4, provide some of the strongest arguments for scholars such as Charles Cosgrove and Tessa Rajak, who argue for a primary Christian audience for the Dialogue. ${ }^{21}$ Building upon their important work, in what follows I will develop two fresh arguments that in my view strongly suggest that Justin expected the Dialogue to be engaged first and foremost by an internal audience. 


\section{Dialogue 80}

First, I propose that we give more weight to the one passage in the Dialogue in which Justin refers to the Dialogue itself. In Dial. 80.3, he writes:

You should know that I do not say this only to you; ${ }^{22}$ I will, to the best of my ability, write a treatise covering our entire conversation and I will record in it that I confess this, which I also confess to you. For I prefer to follow God and the teachings that come from him, rather than human beings or human teachings. ${ }^{23}$

This statement is fascinating for its meta-level reflexivity: Justin writes that he will write what he is currently writing. ${ }^{24}$ The import of this statement for the question of the Dialogue's audience becomes clear when the literary context is taken into consideration. The chapter opens with a question by Trypho:

Tell me, do you really confess that this place, Jerusalem, will be rebuilt...? Do you really expect this to happen or did you come to this confession in order to get the better of us in these inquiries?

$(\text { Dial. 80.1 })^{25}$

Justin responds:

I am not such a sorry figure, Trypho, that I would say something else than what I think. I already confessed to you previously that I and many others think this. Just as you, I am sure, realize that this is going to happen. I also pointed out to you that many true Christians, with pure and godly views, do not adhere to this.

$(\text { Dial. 80.2) })^{26}$

This section of the Dialogue, which also mentions "godless and impious heretics," will be discussed in more detail in Chapter 5 . Here I restrict myself to the observation that Trypho was concerned that Justin took his position on the rebuilding of Jerusalem not out of conviction, but because it furnished him with a rhetorical advantage ("to get the better of us in these inquiries"). Justin explains that his view was not universally held among "true Christians," but he claims that it is nonetheless his true conviction. To support this statement, he promises to record the conversation, adding that he is unconcerned about what other people think: "I prefer to follow God and the teachings that come from him, rather than human beings or human teachings" (Dial. 80.3). This response makes sense only if Justin reckoned that other Christians would read his account; Justin would risk nothing by reiterating his aberrant views to outsiders (of whatever stripe). Trypho's concern is precisely that Justin is taking this particular position only among outsiders and will switch positions when he is not trying to "get the better of them" in disputations. ${ }^{27}$ Justin 
assumes that other Christians will read this document and that they may disagree with him (cf. Dial. 80.2), but he claims that this is of little concern to him. The significance of this passage has been largely overlooked, but it strongly suggests that Justin anticipated a Christian audience for the Dialogue.

\section{Producing the Dialogue}

A second argument for a primarily Christian audience is based on the practical realities that governed book production and circulation in the Roman world. Claims that the Dialogue was intended "for the Jews" or "for the pagans" fail to take seriously how books were actually made and distributed. ${ }^{28}$ How should we imagine, in practical terms, the distribution of a text like the Dialogue to an audience of outsiders? In the Roman world, copies of books were predominantly made and distributed within an author's own social network. Publication (if we can even use that anachronistic term) normally took the form of making a document available to one's friends who could then choose to make further duplicates. As Raymond Starr notes in his classic article on the topic: "Romans circulated texts in a series of widening concentric circles determined primarily by friendship"; 29 and "The channels of circulation ran from one friend to another, never between strangers. A Roman did not ask someone he did not already know to send a book even about a subject in which both were interested. This probably restricted both the number of texts in circulation and the number of people to whom particular texts were accessible." ${ }^{30}$ The process of making a piece of literature public often included a recitatio or public reading, but this too was ordinarily restricted to the social circle of the author. ${ }^{31}$ The commercial book trade was not a real alternative for this socially restricted form of distribution either. Bookshops and dealers were known in second-century Rome, but the book trade was a relatively small enterprise that focused on a limited number of titles. ${ }^{32}$ There is no evidence of any Christian texts making their way to the commercial market prior to the fourth century. ${ }^{33}$ Moreover, the Dialogue would be particularly unsuitable for commercial trade because of its extraordinary length and thus its prohibitive costs. ${ }^{34}$ And even if some booksellers carried a work, copies would usually only be made in response to a request by a customer (which assumes prior interest on the part of the reader); bookstores did not usually have many copies of a book in stock. ${ }^{35}$ 'Public' libraries would similarly not have been a realistic avenue for distribution of a text like the Dialogue. ${ }^{36}$ Such libraries were restricted to the elite and during imperial times "became an all-too-practical expression of imperial patronage of, and attempted control of, cultural life." ${ }^{37}$ They were imperial rather than truly public libraries and consequently not a suitable place for Justin Martyr's writings. ${ }^{38}$ Perhaps authors donated copies of their own works to such libraries, but the books that were taken up in such collections in the second century are unlikely to have included those penned by authors who identified as Christians and were critical of the Roman government. Literary texts in general, and in particular non-elite productions that were of no interest to booksellers and libraries, were distributed via the social 
network of its author. On purely practical grounds, then, it is implausible that the Dialogue was written specifically for an external audience, since there was no good way to reach such an audience. ${ }^{39}$

Harry Gamble notes with respect to the somewhat analogous case of the various Christian apologies that were published around this time,

If pagans could be induced to read such works, they could hardly be expected to go to the trouble or expense of obtaining the copies they read. It has to be supposed that Christians produced the copies and insinuated them among non-Christian readers. Propaganda, more than other types of literature, requires a greater effort of distribution. ${ }^{40}$

As Gamble is aware, though, there is no evidence of any such efforts. To the extent that Christian apologies were formally submitted as petitions, they could (at least in theory) be made public by the Roman bureaucratic apparatus and might reach an external audience via that route. ${ }^{41}$ But for a text such as the Dialogue, no such avenues were available, so we should be skeptical about the possibilities of getting this document to an outside audience, even if it could be demonstrated that early Christian apologies were widely read by outsiders. Moreover, there is little evidence to suggest that early Christians undertook, let alone were successful in, efforts to produce and distribute copies of their liteerature among non-Christian readers. ${ }^{42}$ Tertullian offers ready evidence to the contrary when he complains that "no one comes to our books unless he is a Christian already" (Test. 1.4). And even if one were to suppose that Christians did attempt to reach outsiders through extensive publishing and distribution projects, the Dialogue would hardly be an obvious candidate for such an effort. The text is very long, arguably unnecessarily long (it is full of long quotes from the LXX and substantial repetitions). This creates not only practical problems related to reproduction and distribution time and costs, but also means that an audience of outsiders could hardly be expected to read it in full, let alone study it carefully. ${ }^{43}$

It is much more plausible, then, to assume that Justin anticipated that this text would be read primarily by an internal audience. Perhaps its original setting was comparable to a domestic library. Harry Gamble posits that Christian libraries of the first few centuries resembled most closely the domestic libraries of the GrecoRoman world. He suggests that the "library of the Villa of the Papyri in Herculaneum, the best-known domestic library of the ancient world, is the one most aptly compared to the Christian congregational library." ${ }^{44}$ Perhaps Justin had access to a similar kind of library. The Herculaneum library "was apparently used by a group of Epicurean friends who formed a close-knit philosophical community that gathered in the villa through the generosity of its owner." ${ }^{45}$ We can easily imagine a similar scenario in the case of Justin. Perhaps Marcus Pompeius furnished Justin with a location in Rome and the means to produce and copy literature. The Dialogue, in this scenario, could be studied by students either individually or collectively at Justin's "school." ${ }^{46}$ While hypotheses of an external audience are 
difficult to square with the nature and contents of the Dialogue, one can easily imagine students at Justin's school poring over this long text in order to study the relationship between the old and the new covenant, Jews and Christians, "right thinking" and "demon-inspired" Christians. ${ }^{47}$ If so, the repetitive nature of the text is perhaps best seen as a didactic device meant to imprint the most important and convincing scriptural passages and lines of argument on the student. ${ }^{48}$ The long LXX passages that often receive quite limited commentary in the Dialogue also fit a school setting. Even for an internal audience, their significance probably needed some unpacking, which in the scenario proposed here would be part of the educational experience at Justin's school. ${ }^{49}$ It is also conceivable that Justin and/or his students would expand and supplement the text as new arguments were developed and new scriptural passages were recognized for their apologetic potential, thus further contributing to the complex and convoluted structure of the work. Occasionally copies might have been made or commissioned by Justin's students or by like-minded visitors from around the empire.

All of this is speculative, to be sure. But despite its creativity, the scenario sketched here is eminently possible given what we know about how ancient texts were produced and used. By contrast, theories that posit a "Jewish audience" (or a "pagan audience" for that matter) crumble when asked how they would have worked in practical terms. Even if Justin took the highly unusual step of having many copies of the Dialogue made (either commercially or privately), it is unclear how we should imagine that such copies would be placed in the hands of outsiders, let alone how Justin could have made sure that they were actually read.

The Dialogue itself offers more realistic hints about the ways in which ideas traversed between insiders and outsiders. Trypho makes mention of "many a debate"

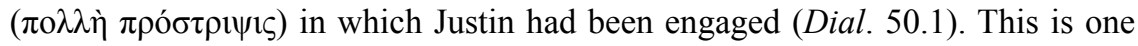
possible venue of exchange. The Dialogue as a whole exemplifies a related form of interaction: a conversation between Jews and Christians. Surely such ways of communicating ideas and arguments must have been more prominent than the exchange of lengthy written treatises such as the Dialogue.

\section{Conclusion}

Regardless of Justin's hopes and dreams regarding the impact of the Dialogue, he must have anticipated that the document would be read primarily by those already within his social circle. ${ }^{50}$ Not all of them were necessarily committed Christians of Justin's kind, but at the very least they must have been in contact with Justin's immediate circle and deeply interested in the Dialogue's message. The identification of the primary audience as internal, perhaps especially members of Justin's school, does not mean that the Jewish-Christian engagement that the text describes is merely a cipher for questions of self-definition. I agree with Stylianopoulos that Justin demonstrates a real interest in converting Jews, but I suggest that the attempt to convince Jews of his reading of the Scriptures has to do, to a significant extent, with the debated status of these Scriptures among 
Christians. This point will be developed and argued in detail in Chapter 4. Justin would no doubt have been very pleased if, via his internal audience, his arguments also reached Greeks and Romans interested in "Christianity" and/or "Judaism," but there is little in the text that suggests he composed the document with them primarily in view. Ultimately the best test for a theory of audience is to see if it "makes sense" of the text, in other words, whether it produces compelling readings. It is to this task that we turn starting with the next chapter.

\section{Notes}

1 Harnack, Die Altercatio Simonis Iudaei et Theophili Christiani, 77-8. See also Adolf von Harnack, Ist die Rede des Paulus in Athen ein ursprünglicher Bestandteil der Apostelgeschichte? Judentum und Judenchristentum in Justins Dialog mit Trypho, nebst einer Collation der Pariser Handschrift Nr. 450., TU 3.9.1 (Leipzig: J.C. Hinrichs, 1913), 51-2 n. 2.

2 Franz Overbeck, "Über die Anfänge der patristischen Literatur," Historische Zeitschrift 48 (1882): 448 n. 1, see also Theodor Zahn, "Studien zu Justinus Martyr," ZKG 8 (1886): 1-84.

3 E.g., Bernd Reiner Voss, Der Dialog in der frühchristlichen Literatur (München: W. Fink, 1970), 38-9; Niels Hyldahl, Philosophie und Christentum: Eine Interpretation der Einleitung zum Dialog Justins, Acta theologica Danica 9 (Kopenhagen: Munksgaard, 1966), 20. This thesis is especially remarkable given that the text itself states that the Jewish interlocutor, Trypho, claims that he was "taught by Corinthus, the Socratic philosopher" (Dial. 1.2).

4 For other arguments against the "pagan hypothesis," see Theodore G. Stylianopoulos, Justin Martyr and the Mosaic Law, Dissertation Series 20 (Missoula, MT: Society of Biblical Literature; Scholars Press, 1975), 169-95; Cosgrove, "Justin Martyr and the Emerging Christian Canon," 211-19; Rajak, "Apologetic"; Allert, Revelation, Truth, Canon, and Interpretation, 38-53; Bobichon, Justin Martyr, Dialogue avec Tryphon, 129-66.

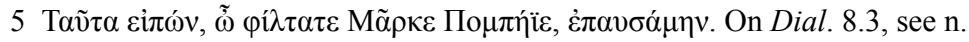

6 E.g., Harnack, Judentum und Judenchristentum in Justins Dialog, 51-2 n. 2.

7 E.g., Stylianopoulos, Justin Martyr and the Mosaic Law, 170 n. 10.

8 Henrik Mouritsen, The Freedman in the Roman World (Cambridge; New York: Cambridge University Press, 2011), 39: “[T] he freedman's new civic identity required a full Roman name. Like a son he therefore received the gentilicial nomen of the patron, and during the republic it also became common practice to give him the patron's praenomen, in the same way as sons increasingly received that of their fathers." Statistical analysis suggests that a Greek or otherwise "barbaric" (i.e., non-Latin) cognomen could be indicative of a servile background, see, e.g., Ibid., 124-6, 231-2; Christer Bruun, "Greek or Latin? The Owner's Choice of Names for Vernae in Rome," in Roman Slavery and Roman Material Culture, ed. Michele George (Toronto: University of Toronto Press, 2013), 21-5. Unfortunately, Justin does not give us Marcus Pompeius's cognomen.

9 On literary patronage in Rome, see Barbara K. Gold, ed., Literary and Artistic Patronage in Ancient Rome (Austin: University of Texas Press, 1982); Barbara K. Gold, Literary Patronage in Greece and Rome (Chapel Hill: University of North Carolina Press, 1987); Elaine Fantham, Roman Literary Culture: From Plautus to Macrobius (Baltimore: The Johns Hopkins University Press, 2013), 89-95; David E. Aune, "Dedications (of Books)," in The Westminster Dictionary of New Testament and Early Christian Literature and Rhetoric (Louisville, KY: Westminster John Knox, 2003), 123-4; Harry 
Y. Gamble, Books and Readers in the Early Church: A History of Early Christian Texts (New Haven: Yale University Press, 1995), 84, notes: "It often happened that the work was dedicated to someone, usually a person of stature whom the author hoped would take interest and sponsor its wider distribution" (cf. Wilhelm Schubart, Das Buch bei den Griechen und Römern [Heidelberg: Lambert Schneider, 1962], 134-9). The production and distribution of the Dialogue is addressed later on in the present chapter.

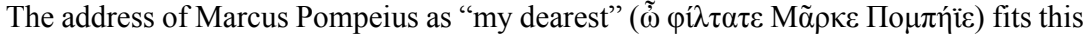
theory, because friendship language often characterized literary patron-client relations. See Peter White, "Amicitia and the Profession of Poetry in Early Imperial Rome," JRS 68 (1978): 74-92.

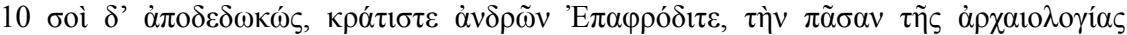

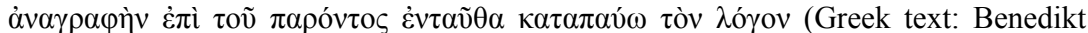
Niese, Flavii Iosephi opera, reprinted edition 1955 [Berlin: Weidmann, 1895]). On Epaphroditus, see Steve Mason, Life of Josephus, Flavius Josephus: Translation and Commentary, vol. 9 (Leiden; Boston: Brill, 2001), 173. The Vita was intended as an appendix to the Antiquities (cf. Ant. 20.266). Ephaphroditus is mentioned in the beginning of Ant. as well, which may be compared to the possible reference to Marcus Pompeius in Dial. 8.3 ("Pompey" appears in the Latin version, but not in the Greek).

11 Cf. Loveday Alexander, The Preface to Luke's Gospel: Literary Convention and Social Context in Luke 1.1-4 and Acts 1.1, SNTSMS 78 (Cambridge; New York: Cambridge University Press, 1993), 57-8.

12 The most significant passage supporting a "pagan" identity for Trypho's companions is Dial. 23.3: "Therefore, Trypho, I will proclaim to you as well as to those who wish

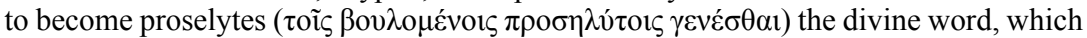
I heard from that man. You see that the elements neither idle nor rest on the Sabbath.

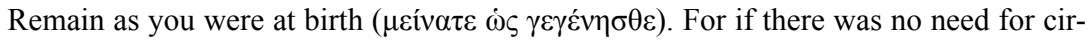
cumcision before Abraham or of Sabbath observance and feasts and sacrifices before Moses, there is no need for them now ..." Zahn argued that this passage identifies Trypho's companions as "pagan" converts to Judaism (Zahn, "Studien zu Justinus Martyr," 57; similarly, Skarsaune, The Proof from Prophecy, 258; Graham Stanton, "GodFearers': Neglected Evidence in Justin Martyr's Dialogue with Trypho," in Studies in Matthew and Early Christianity, ed. Markus N.A. Bockmuehl and David Lincicum, WUNT 309 [Tübingen: Mohr Siebeck, 2013], 355-8). However, as Stylianopoulos, Justin Martyr and the Mosaic Law, 174-5 notes, the word $\pi \rho 0 \sigma \hat{\eta} \lambda v \tau o \varsigma$ is also used by Justin with reference to converts to the Christian tradition (Dial. 122.5, cf. 28.2), so perhaps Justin is speaking here of Jews who wish to join the Christians. One could object that the context suggests that $\pi \rho \circ \sigma \eta \dot{\lambda} v \tau$ ot refers to non-Jews, because Justin tells them to "stay as you were at birth," but Justin seems to be addressing Trypho as well when says "stay as you (pl.) were at birth," so perhaps the phrase is best understood as a general comment on the obsolete nature of circumcision. This is suggested also by the fact that Dial. 23.3-5, which argues that neither circumcision nor Sabbath, festivals and sacrifices are important anymore, takes up Trypho's question as to why Christians do not observe these rituals (10.3). Justin explains that such commandments have been instituted because of the hardheartedness of the Jews, but that they are not required by nature. Just as the natural state of the "elements" is not to refrain from work on the Sabbath (23.3), the natural state of human beings is to be uncircumcised, and there is no need to change this state. Justin's claim that there is no need for anyone (including proselytes) to be circumcised thus goes back to Trypho's question as to why Christians do not observe circumcision (10.3). Importantly, Justin does not make any clear connection between "those who wish to become proselytes" and Trypho's companions. Justin does not, in fact, identify the two groups.

Whatever one makes of Dial. 23.3, then, given the interpretative challenges of this passage we should perhaps not put too much weight on it, especially since the evidence 
from other texts is less ambiguous. In Dial. 122.2 Justin says: "the proselytes not only do not believe, but they blaspheme his name twice as much as you (pl.) do." In this passage, Justin's interlocutors are evidently not identified as proselytes (or potential proselytes). Dial. 123.1 and 123.2 likewise clearly distinguish among the members of Justin's audience by referring to them as "you" (pl.), in contradistinction to "the proselyte(s)." This broader sample of evidence tilts the balance in favor of the view that Trypho's friends were not (potential) "pagan" proselytes to Judaism.

13 Victor Tcherikover, "Jewish Apologetic Literature Reconsidered," Eos 48 (1956): 169-93, has been especially influential in this regard.

14 Stylianopoulos, Justin Martyr and the Mosaic Law; Allert, Revelation, Truth, Canon, and Interpretation; David Rokeah, Justin Martyr and the Jews, JCP 5 (Leiden; Boston: Brill, 2002), 6-11. Bobichon, Justin Martyr, Dialogue avec Tryphon, 129-66 is sympathetic to Stylianopoulos's argument and rejects the notion of "pagans" as the primary audience, but believes that Justin is (indirectly) addressing a broader audience than "just" Jews and/or Christians.

15 Indicative of a lack of clear boundaries are, in addition, such passages as Dial. 134.3: "Leah stands for your people (i.e., the synagogue), and Rachel for our church. And Christ still serves on their behalf and on behalf of his servants who are in both" ( $\dot{\alpha} \lambda \lambda \dot{\alpha}$

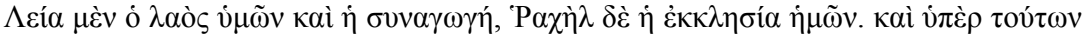

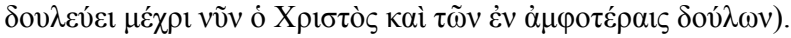

16 Similarly, Boyarin, Border Lines, 37-73.

17 Stylianopoulos, Justin Martyr and the Mosaic Law, 32.

18 Ibid., $10-11$.

19 Ibid., 39-40.

20 Ibid., 38, 44.

21 Cosgrove, "Justin Martyr and the Emerging Christian Canon," 218; Rajak, "Apologetic," 78. See also, e.g., Stephen G. Wilson, Related Strangers: Jews and Christians, 70-170 C.E. (Minneapolis, MN: Fortress Press, 1995), 261-5.

22 Most translations render this phrase as a purpose clause ("in order that you might know"). That is, however, an unusual sense for ö $\tau$ + indicative. Marcovich proposes to emend the text to ö $\pi \omega \varsigma$... غ̇ं $\iota \tau \tau \tilde{\eta} \sigma \theta \varepsilon$. Bobichon, Justin Martyr, Dialogue avec Tryphon, 1.407 , on the other hand, translates "Et puisque ce n'est pas uniquement pour vous que je tiens ces propos, vous le savez ..." (taking ö $\tau \iota$ as introducing a dependent statement [Smyth, Greek Grammar, $\S \S 2576-2588$, esp. 2581]). This is not an entirely satisfactory solution either, because ő $\tau$ should be followed by an indicative (or an optative), not an infinitive. Moreover, the passage gives the impression that this is the first time that Justin mentions that he will put the conversation down in writing. The least problematic solution is perhaps to take ő $\tau 1$ as introducing a dependent statement (with Bobichon) and to take $\dot{\varepsilon} \pi \dot{i} \sigma \tau \alpha \sigma \varepsilon \varepsilon$ as imperative.

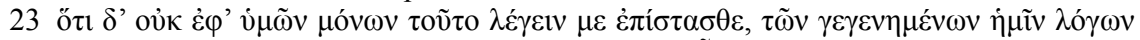

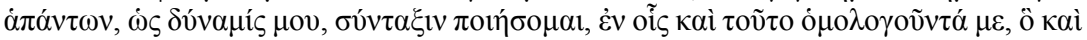

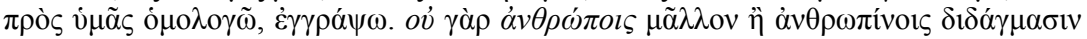

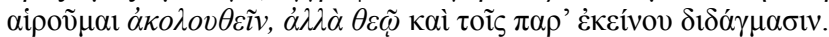

24 Against the majority of scholars, Prigent, Justin et l'Ancien testament, 67, has argued that Justin has not the Dialogue, but the Treatise on the Resurrection in mind (which is spurious according to most scholars, but not in Prigent's view), while Bobichon, Justin Martyr, Dialogue avec Tryphon, 2.786-787, entertains the possibility that the reference may be to the Syntagma. But given that Justin clearly refers to a document that covers

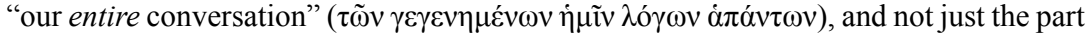
that refers to the resurrection or to "heresies," these suggestions are implausible.

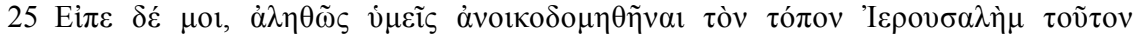

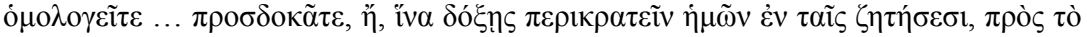
$\tau \alpha \tilde{\tau} \tau \alpha$ ó ${ }_{0} \lambda \sigma \gamma \varepsilon \tilde{v} v \dot{\varepsilon} \chi \omega ́ \rho \eta \sigma \alpha \varsigma ;$ 


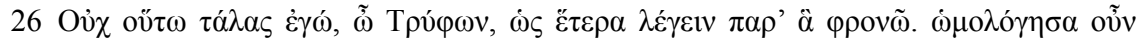

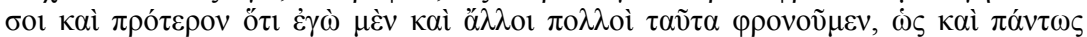

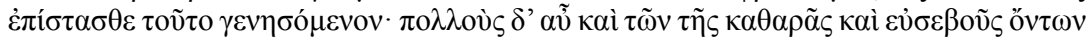

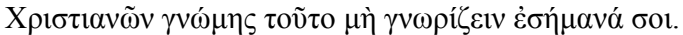

27 Given the context, in which Trypho is skeptical about Justin's beliefs with respect to

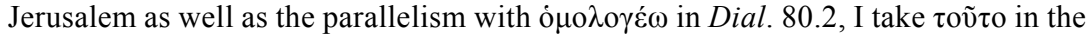

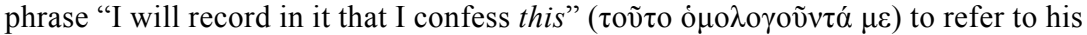
position on the rebuilding of Jerusalem. Alternatively, one could take $\tau$ oṽ $\tau$ o to refer to the immediately preceding statement that some Christians are "godless and impious heretics [etc.]." This would not substantially affect my argument with respect to the presumed audience, because in that case too, Justin's assurance that he is willing to put this in writing makes best sense if he expected that other Christians would read it.

28 Important studies in this area include Theodor Birt, Das antike Buchwesen in seinem Verhältniss zur Litteratur (Berlin: W. Hertz, 1882); Frederic G. Kenyon, Books and Readers in Ancient Greece and Rome (Oxford: Clarendon Press, 1951); Schubart, Das Buch bei den Griechen und Römern; Eric G. Turner, Greek Papyri: An Introduction (Princeton, NJ: Princeton University Press, 1968); Patricia E. Easterling and Bernard M.W. Knox, "Books and Readers in the Greek World," in The Cambridge History of Classical Literature, Volume 1: Greek Literature (Cambridge: Cambridge University Press, 1985), 1-41; Annette Dortmund, Römisches Buchwesen um die Zeitenwende: War T. Pomponius Atticus (110-32 v. Chr.) Verleger? (Wiesbaden: Harrassowitz, 2001); William A. Johnson, Bookrolls and Scribes in Oxyrhynchus (Toronto; Buffalo: University of Toronto Press, 2004); William A. Johnson, Readers and Reading Culture in the High Roman Empire: A Study of Elite Communities (New York: Oxford University Press, 2010); and specifically with reference to the Christian material: Gamble, Books and Readers in the Early Church; Martin Wallraff, Kodex und Kanon: Das Buch im frühen Christentum, Hans-Lietzmann-Vorlesungen 12 (Berlin: Walter de Gruyter, 2013).

29 Raymond Starr, "The Circulation of Literary Texts in the Roman World," CQ 37 (1987): 213. See also Johnson, Readers and Reading Culture in the High Roman Empire, 85-91, who, by means of a case study of Galen, provides a "thicker" description of how book distribution worked in practice.

30 Starr, "The Circulation of Literary Texts in the Roman World," 216-17. Similarly, Gamble, Books and Readers in the Early Church, 85.

31 Starr, "The Circulation of Literary Texts in the Roman World," 214. Gamble, Books and Readers in the Early Church, 84: "a small and sympathetic circle of acquaintances." For a somewhat different perspective on the size of such gatherings, see Jon W. Iddeng, "Publica Aut Peri! The Releasing and Distribution of Roman Books," Symbolae Osloenses 81 (2006): 60-3. On social aspects of reading in the Roman Empire more generally, see Johnson, Readers and Reading Culture in the High Roman Empire (cf. esp. pp. 52-6 on the recitatio).

32 Starr, "The Circulation of Literary Texts in the Roman World," 219-23; Gamble, Books and Readers in the Early Church, 85; Rex Winsbury, The Roman Book: Books, Publishing and Performance in Classical Rome (London: Duckworth, 2009), 57-66; Iddeng, "Publica Aut Peri! The Releasing and Distribution of Roman Books," 63-77.

33 Gamble, Books and Readers in the Early Church, 140.

34 On the economics of ancient book production, see, e.g., Roger S. Bagnall, Early Christian Books in Egypt (Princeton, NJ: Princeton University Press, 2009), 50-69.

35 Starr, "The Circulation of Literary Texts in the Roman World," 220.

36 On public libraries in Rome, see especially T. Keith Dix and George W. Houston, "Public Libraries in the City of Rome from the Augustan Age to the Time of Diocletian," Mélanges de l'École Française de Rome 118 (2006): 671-717, and Jason König, 
Aikaterini Oikonomopoulou, and Greg Woolf, eds., Ancient Libraries (Cambridge; New York: Cambridge University Press, 2013).

37 Winsbury, The Roman Book, 67.

38 Scholars have suggested that there may have been more widely accessible libraries in bath buildings. This theory is especially interesting in the present context, given the claim in Justin's Martyrdom that his living quarters were located above "the baths of Myrtinus." However, evidence for the existence of such libraries is not very convincing, as noted by T. Keith Dix, "Libraries, Private, Public (Greece and Rome)," in The Encyclopedia of Ancient History, ed. Roger S. Bagnall et al. (Malden, MA: WileyBlackwell, 2013), 4063-7. On Justin's location in Rome, see Harlow Gregory Snyder, " 'Above the Bath of Myrtinus': Justin Martyr's 'School' in the City of Rome," HTR 100 (2007): 335-62.

39 Further complicating the question of audience, we should note that the precise scope of the audience could not be controlled by the author, since he or she had no power over the text once it started circulating.

40 Gamble, Books and Readers in the Early Church, 113.

41 Cf. pp.13-14 above on 1 Apol.

42 Admittedly, Celsus did know about the Dialogue between Jason and Papiscus (Origen, Cels. 4.52), but he likely made more extraordinary efforts to acquire Christian literature in order to write an effective rebuttal. On the question of Celsus's knowledge of $1 \mathrm{Apol}$., see p. $126 \mathrm{n}$. 46. For his possible familiarity with other Christian writings, see Clemens Scholten, "Die Funktion der Häresienabwehr in der Alten Kirche," VC 66 (2012): 257 n. 101, and the literature cited there.

43 Moreover, with respect to the theory of a primary Jewish audience we should note that even if by some unusual development Justin would have been able to get a number of copies of the Dialogue in the hands of Jewish outsiders and entice them to begin studying it, it is hard to imagine that they kept going after reading some of Justin's harsh polemics against Jews (see Chapter 4).

44 Gamble, Books and Readers in the Early Church, 197.

45 Ibid., 197-8.

46 For discussion of the nature of Justin's "school," see Jörg Ulrich, "What Do We Know about Justin's 'School' in Rome?," ZAC 16 (2015): 62-74; Tobias Georges, "Justin's School in Rome: Reflections on Early Christian 'Schools'," ZAC 16 (2015): 75-87. On early Christian schools more generally, see Ulrich Neymeyr, Die christlichen Lehrer im zweiten Jahrhundert: Ihre Lehrtätigkeit, ihr Selbstverständnis und ihre Geschichte, VC Supplements 4 (Leiden; New York: Brill, 1989); Thomas Schmeller, Schulen im Neuen Testament? Zur Stellung des Urchristentums in der Bildungswelt seiner Zeit, Herders biblische Studien 30 (Freiburg; New York: Herder, 2001); Christoph Markschies, "Lehrer, Schüler, Schule: Zur Bedeutung einer Institution für das Antike Christentum," in Religiöse Vereine in der römischen Antike: Untersuchungen zu Organisation, Ritual und Raumordnung, ed. Ulrike Egelhaaf-Gaiser and Alfred Schäfer, STAC 13 (Tübingen: Mohr Siebeck, 2002), 97-120.

47 According to the Martyrdom of Justin, his "school" was open to a wide audience: "Anyone who wished could come to my abode and I would impart to him the words of the truth" (Recension A.3, B.3, cf. Dial. 64.2). Even though the historical reliability of the Martyrdom is subject to debate, we need not assume that everyone visiting Justin's school was necessarily already a Christian. However, according to the Martyrdom (A.4, B.4), the students that Justin had with him at the time of his death were brought up as Christians.

48 Cf. Dial. 85.5, where Justin defends his repetitive appeal to the Jewish Scriptures by contrasting this practice with "believing oneself capable of thinking of something to

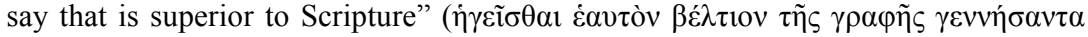




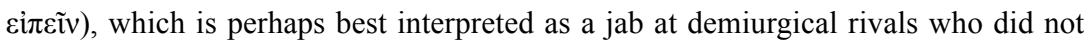
acknowledge the supreme authority of the biblical writings.

49 In Dial. 55.3, Justin introduces an argument on the basis of scriptural passages by saying that "they do not need explanation, but only a hearing." In what follows, though, Justin does explain the passage quite extensively. The point, then, I suggest, is not so much that Justin believes that the meaning of Scripture is self-evident, but rather that the "stubborn Jews" require extraordinarily full and elaborate commentary in order to recognize what should be obvious. This reading fits with Justin's tirade about the Jews' inability to understand in the immediate context.

50 The reading public proposed here is, incidentally, also the only one attested historically. Tertullian, evidently a Christian, read Justin's Dialogue. See, e.g., Geoffrey D. Dunn, Tertullian's Aduersus Iudaeos: A Rhetorical Analysis, North American Patristics Society Patristic Monograph Series 19 (Washington, DC: The Catholic University of America Press, 2008), 44. 


\section{THE DIALOGUE AS AN ANTI- HERETICAL TEXT}

The preceding two chapters established two major points. First, Justin had been very much concerned with, and engaged in, the battle against Christian demiurgism for an extended period of time prior to writing the Dialogue. And second, Justin anticipated that his initial and primary audience would be an internal one. Taken together, these two points suggest the possibility that Justin utilized the Dialogue to continue his campaign against demiurgical "heresy." Justin knew that this treatise would be read by an internal audience still very much confronted by the ideas against which he had previously campaigned, because the demiurgists had by no means exited the early Christian stage by 160-65 CE and still presented a challenge to Justin's kind of Christianity.

That Justin responds to this challenge in the Dialogue becomes an especially attractive hypothesis once we recognize that virtually every topic that the Dialogue broaches is immediately relevant to Justin's confrontation with demiurgical forms of Christianity. At the heart of the Dialogue is Justin's attempt to demonstrate the truth of his claims about Jesus on the basis of Scripture. On the surface level, the proof-from-prophecy approach that permeates the document constitutes an attempt to convince a Jewish audience of the truth of the Christian message. We know, though, that Justin was painfully aware that the validity of the texts that supplied this proof was by no means universally accepted among those who identified as Christians. The proof-from-prophecy had the potential, however, not only to convince non-Jesus-believing Jews who accepted the authority of the Scriptures that they were fulfilled in Jesus, but also to persuade believers in Jesus that he was the fulfillment of Israel's Scriptures, and that these Scriptures were hence divinely inspired and could not be discarded. Similarly, Justin's arguments demonstrating that God was not inconsistent when he gave Israel a different Law than he imposed on the followers of Jesus are pertinent not only to Jewish critics who wondered why Christians abandoned the Mosaic Law, but also to those among the Christians who considered God's seeming inconsistency in this regard to be evidence that there were two gods at work: the Demiurge, who was responsible for the Mosaic Law, and the Father of Jesus Christ, who was responsible for the "new" Law. In fact, virtually all of the issues discussed in the Dialogue, from the relationship between the Old and the New Law to the consistency of God's demands 
and character, as well as the continuity between the Old and the New Israel, are immediately relevant to Justin's debate with the demiurgists. ${ }^{1}$ At every turn, Justin presents a vision of Scripture, God, and ekklesia at odds with the notions advanced by his demiurgical opponents. Justin claimed the Jewish Scriptures as his own, while they (at least partly) rejected them. Justin identified the Jewish God with the Father of Jesus Christ, they disagreed. Justin saw the Christian community as the continuation and indeed as the replacement of Israel, while demiurgists like Marcion held that it was essentially unrelated to Israel.

One way to illustrate the pertinence of the contents of the Dialogue to these internal Christian debates is by comparing the Dialogue to Book Four of Irenaeus's Adversus Haereses. Irenaeus, writing just a few decades later than Justin (c. $180 \mathrm{CE}$ ), takes up many of the same themes and arguments that Justin develops in the Dialogue, but he puts them explicitly in the service of an attack on demiurgical Christians. Irenaeus argues, like Justin, that the Old Testament speaks everywhere of Christ, that the Old and New covenants are compatible and have the same author (4.12), that the Mosaic Law was a temporary measure implemented because of the hardheartedness of the Jews and that this is not an indication of inconsistency on God's part (4.15), that circumcision had nothing to do with attaining righteousness but only served to make the Jewish people recognizable (4.16), and so on. ${ }^{2}$ These claims all appear in a section that expressly targets Marcion and demiurgists like him. ${ }^{3}$ It is implausible that Justin, who had already been so invested in the battle against demiurgists, was unaware of the potential to undercut their views when he discussed these very same themes and included them in a treatise that he must have known would be read primarily by an internal audience. Tertullian likewise discusses many of the same issues in Adversus Marcionem (especially in Book 3). Moreover, he provides evidence that some of the scriptural passages discussed by Justin and Trypho were also cited by Marcionites to dispute the claim that Jesus was the Messiah predicted in the Jewish Scriptures; these exegetical debates about the interpretation of the Jewish Bible were evidently central to the clash between demiurgical and other Christians. ${ }^{4}$

This chapter suggests that the Dialogue as a whole can be read as an extended argument for a particular form of Christianity over and against demiurgical alternatives. It argues this case by demonstrating the presence of passages throughout the Dialogue in which Justin addresses issues that are in some ways more relevant to the debate between him and his "heretical" rivals than to the conversation with Trypho (or a Jewish audience more generally). To be sure, simply because much in a text can be read as polemical does not, of course, mean that it must be so read. Scholars have arguably been overeager to imagine polemics at every turn. Marcion has been especially popular in this regard; sightings of his spectre have been reported all over the map of early Christian (and even early Jewish) literature. However, in contrast to many other instances, in the present case we find such polemic in a writing produced by an author who was certainly aware of the opponents against whom he appears to be polemicizing. Indeed, the Dialogue itself contains passages that expressly target those opponents (cf. esp. Dial. 35.6, to be 
discussed in Chapter 5). It is entirely reasonable, then, to assume that Justin was fully aware of what he was doing when he developed a wide range of arguments that had the potential to undercut Christian demiurgical theologies.

\section{Internal concerns in the Dialogue}

The Dialogue refers directly to demiurgical Christians at certain points, which will be discussed in Chapter 5. Here I focus on those passages in the Dialogue where the claims of Justin's Christian rivals rather than those of his Jewish interlocutors appear to be guiding the conversation. ${ }^{5}$ Some of these passages have been noted in previous scholarship, but they have often been dismissed as "reflections" or "survivals" of an earlier anti-heretical effort that Justin later recycled against the Jews. For instance, Hans von Campenhausen claimed with respect to a fairly large section of the Dialogue: "Es handelt sich hier um einen geschlossenen Traktat (dial. 10-29), der ursprünglich gegen Gnostiker und Markioniten gerichtet gewesen sein muß." ${ }^{\circ 6}$ While von Campenhausen deserves credit for recognizing the anti-heretical force of this and other passages, his solution is unconvincing. The difficulty with hypotheses like this is twofold. They not only require Justin to have been a very sloppy editor, who included material (even an entire tractate!) that did not fit its context, but they also fail to recognize that not simply a few passages, but essentially the entirety of the Dialogue is pertinent to the debate with demiurgical forms of Christianity.

One of the first and most telling moments in which Justin appears to respond to his Christian rivals rather than to his Jewish interlocutors comes early on in the Dialogue. Trypho sets the stage for the first section of the treatise (Dial. 10-29), which primarily deals with the question of the Mosaic Law, by saying to Justin:

You simply despise this covenant and you neglect (the commandments) that follow, yet you attempt to persuade us that you know God even though you are doing none of the things that God-fearing people do. If you are able to defend yourself against these charges and can show how and what you are hoping for even though you are not keeping the Law, we would listen to this defense of yours most gladly, and let us then likewise examine the other issues together.

$(\text { Dial. 10.4 })^{7}$

Trypho asks about the reason that the Christians no longer observe the Mosaic Law. Justin's response is striking, because it introduces what seems to be an entirely unrelated point (Dial. 11.1):

"There will never be another God, Trypho, nor has there ever been one," I said to him, "except the one who made and ordered this universe. It is also not the case that you consider another to be God than we do; we both (consider to be God) him who led your fathers out of Egypt with a strong 
hand and an outstretched arm. We have not placed our hope in anyone else, for there is no one else, but (we have placed our hope in) this one in whom you have also placed your hope, namely the God of Abraham and Isaac and Jacob."

As Theodore Stylianopoulos has argued, "In this passage the emphatic rejection of 'another God' is strikingly out of context. Not Trypho, therefore, but Marcion is here in view." In addition to Justin's rejection of the notion of "another God," his emphasis that the one True God is he who "made" and "ordered" the world strongly suggests that he is positioning himself over against demiurgical theologies. There was no need to discuss the existence of another God or to stress that God is the Creator in response to Trypho's question concerning the validity of the Mosaic Law. These issues do not arise directly from Trypho's concerns. In the context of the conversation with Trypho this comment is therefore indeed "strikingly out of context." On the reading proposed in this chapter, this statement is included in the Dialogue not as the result of careless writing or editing, but as part of a larger effort to undercut rival Christian theologies (including but not limited to that of Marcion and his followers). By including this comment about the nonexistence of "another god" early on in the Dialogue, Justin signals to his audience that he will demonstrate how it is possible to maintain that the Law is no longer valid without resorting to the demiurgical position that separates the lawgiver (i.e., the Demiurge) from the True God. ${ }^{10}$ The position of his Christian rivals was fairly straightforward: since the Law of the Jews was given by the inferior Demiurge, it is invalid. In response, Justin seeks to demonstrate why that conclusion is correct, but its premise false. He will argue that Christians are under no obligation to follow the Law, but not by positing some other divinity. Justin stresses that his God is "the God of Abraham and Isaac and Jacob," thereby creating a contrast not with Trypho, but with his Christian rivals, who "blaspheme the God of Abraham and Isaac and Jacob," as he puts it in Dial. 80.4 (cf. Dial. 35.5).

Key to Justin's alternative explanation of why the Law is no longer valid is that it was a temporary measure, and that Scripture itself had already announced another, universally valid law (Dial. 11.3, 12.1, 21.3, 34.1, etc.). The old Law, Justin claims, was instituted because of the disobedience and "hardheartedness" of the Jewish people. ${ }^{11} \mathrm{He}$ states in Dial. 18.2, "we would have simply observed the circumcision of the flesh and the Sabbaths and all the festivals had we not known why they were imposed upon you, namely because of your trespasses and hardheartedness" (cf. Dial. 21.1, 22.1, 22.11, 27.2, 27.4). ${ }^{12}$ Moreover, according to Justin, the Jews have missed the true meaning of the commandments of circumcision, fasts, Sabbath, and so on. They have failed to realize that "all of the other matters constituted by Moses" are "types, symbols, and announcements of what would happen to Christ and those who, as was already known, would believe in him, and likewise of what would be done by Christ himself" (Dial. 42.4). ${ }^{13}$ The Jews did not recognize the function of the Law as foreshadowing the ministry of Christ and his followers. Because the Christians do realize this and because they 
are aware that the Law was instituted because of the obduracy of the Jews, they are under no obligation to follow the Law. It is for these reasons that they reject Law observance, not because the Law was given by another God.

Justin's twin points - that the same God is responsible for both the Old and the New Law and that he was not inconsistent in issuing these two very different sets of demands - are dominant themes throughout the Dialogue, especially in the first section (10-29). The centrality of these issues for Justin is indicated among other passages by Dial. 23.1-2, which clearly echoes the concerns of Dial. 11.1, quoted above:

If we do not acknowledge these things in this manner we fall into absurd notions as a result, such as that a different God existed in the time of Enoch and all the others who did not have the circumcision of the flesh and did not keep the Sabbath and did not do any of the other things commanded by Moses, or that God did not want every group of people to always perform the same righteous acts. It is manifestly ludicrous and foolish to make such claims. We must conclude therefore that sinful people were the reason that God, who is always the same, commanded these and similar things and that he is benevolent, prescient, without any need, just and good. ${ }^{14}$

This passage reveals what is at stake for Justin. If his theory that the Law was given primarily because of the disobedience of the Jews is rejected, one is left, he argues, with two options: either there are multiple gods or the Biblical God is inconsistent. Such notions were advocated by demiurgical Christians, who argued that there were indeed multiple gods, and that one of them, an inferior, inconsistent being, was the god encountered in the Jewish Scriptures. ${ }^{15}$ Justin's own explanation for the giving of the Law, then, provides an alternative to such demiurgical theologies. The pertinence of this internal conflict to Justin's comments is further suggested by Dial. 23.2, where he asserts that his account of the reasons for the giving of the Law enables him to hold that God is "benevolent, prescient, without any need, just and good." These characteristics were hotly debated among Justin's Christian contemporaries. For Marcion and others, the biblical God was not good and he was just only in a certain sense. ${ }^{16} \mathrm{He}$ and likeminded others similarly disputed that this figure was prescient, needful of nothing, and benevolent or sympathetic to human beings $(\varphi 1 \lambda \alpha \dot{\alpha} \theta \rho \omega \pi \circ \varsigma) .{ }^{17}$ These characteristics were subject to debate among Justin's internal audience, not so much for Trypho (or non-Jesusbelieving Jews more generally). ${ }^{18}$

The issues mentioned regarding God's character in Dial. 23.2 come to the fore elsewhere in the Dialogue as well. For instance, with respect to the question of whether God is "needful of nothing," Justin writes: "Because of the sins of your people and because of your idolatry, not because he needed such sacrifices, did he command that these things be done" ${ }^{19}$ (Dial. 22.1). ${ }^{20}$ The reference to God's not needing anything is only of limited relevance to the conversation at 
hand. Trypho and his companions have given no indication that they believe that God "needs" sacrifices or a temple, but we know that this issue was pertinent to the debate between demiurgists and other Christians. Irenaeus argues against his demiurgical opponents that God does not "need" sacrifices in A.H. 4.29.1-5, 4.31.5. And Tertullian takes up the issue too, when he writes in his harangue against Marcion, "Nor should anyone find fault with the burdensome expense of sacrifices and the troublesome scrupulosities of services and oblations, as though God needed such things for his own sake" (A.M. 2.18.3). ${ }^{21}$ The question of whether God is prescient comes up again in Dial. 99.3. There Justin states, "it was not because of lack of understanding that God asked Adam where he was, and Cain where Abel was." ${ }^{22}$ Christian contemporaries who regarded the Jewish God as an inferior Demiurge, pointed to precisely these biblical episodes as evidence of his ignorance. ${ }^{23}$

Justin was evidently aware that there were indeed some in his mid-second century context who used the Jewish Scriptures in an effort to demonstrate God's inconsistency and inferiority:

\begin{abstract}
You can blame it on your own ${ }^{24}$ wickedness that those who lack understanding can falsely accuse God of not having always taught the same righteous acts to everyone. For such teachings appear irrational and unworthy of God to many people who have not received the grace to understand that (these teachings) called your malignant and mentally diseased people to correction and spiritual repentance or (to understand that) the prophecy that came forward after Moses's death is eternal.
\end{abstract}

$(\text { Dial. 30.1 })^{25}$

According to Justin, the Jews' disobedience necessitated a shift in legislation, which created the impression that God was inconsistent. Therefore, he suggests, they are to blame for the fact that certain people accuse God of inconsistency. ${ }^{26}$ The people whom Justin mentions here (i.e., "those who lack understanding") are distinguished from the Jews, whose sinfulness is responsible for the former's wrongheaded conclusions. Who might these people who "lack understanding" and accuse the Jewish God of inconsistency be? The description fits Justin's demiurgical opponents well. Justin signals the existence of such people, thereby confirming that he is not speaking of hypothetical claims about the biblical divinity. He is responding to ideas actually circulating in his world. This is of course confirmed by an abundance of external contemporary evidence as well (Letter of Ptolemy, Irenaeus, etc.).

Christian demiurgists were admittedly by no means the only ones debating difficulties and inconsistencies in the Jewish Scriptures. There was a broad and longstanding tradition of identifying (and trying to resolve) such difficulties. ${ }^{27}$ Yet the fact that it is they whom Justin mentions by name in this treatise (see esp. Chapter 5) in combination with the observation that Justin had been very concerned about them in his career thus far (see Chapter 1), strongly suggests that Christian 
demiurgists are primarily in view when Justin scolds those who imagine that the Jewish Scriptures and its God are inconsistent and contradictory.

Justin does so again in Dial. 65.2, when he refers to "those who believe that the

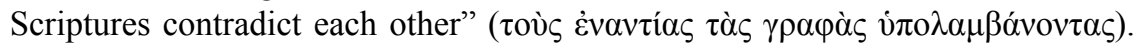
In response, Justin states, "I would not dare to ever think or say" that some passages in Scripture contradict others. "But," he adds, "if such a Scriptural passage that seemed contradictory was brought forward, a passage falsely appearing to be contradictory (because I am completely convinced that no passage of Scripture contradicts another), I myself would rather confess that I do not understand the things that have been said and I would exert myself to persuade those who believe that the Scriptures contradict each other to think the same." ${ }^{28}$ Here Justin again confirms his awareness of people who believe that the Scriptures are inconsistent. Moreover, he again seems to be looking beyond the issue immediately at hand and addressing the situation of his Christian readers, who found themselves confronted with such arguments. In the case of apparent contradictions, Justin recommends openly confessing one's ignorance rather than drawing far-reaching conclusions about God and Scripture. This may be read as an implicit indictment of his Christian rivals, who did precisely that. ${ }^{29}$

Justin intimates at various points that such apparent contradictions derive from a failure to interpret the Scriptures appropriately. In Dial. 112.1, he complains, "by interpreting these passages in an earthly matter, you render God guilty of every weakness, if you understand them in such a wooden manner and without examining the force of what is being said." ${ }^{30}$ The influence of demiurgical exegesis is readily apparent. It was demiurgists like Marcion, not Jews like Trypho, who imputed to the Jewish God "every weakness" based on what Justin and other retrospectively orthodox authors regarded as an overly literal reading of Scripture. ${ }^{31}$ Justin illustrates this accusation with a discussion of the bronze serpent (Numbers 21):

Indeed even Moses would thus be judged a transgressor of the Law; because having commanded that no likeness should be made of anything either in heaven or on the earth or in the sea, he himself then made a bronze serpent ... Shall we then senselessly interpret such things according to what your teachers say and not (regard them as) symbols? Should we not interpret the sign as a reference to the image of the crucified Jesus? For in this way we will also bring to an end the confusion about what the Lawgiver did ... Indeed, these things happened and were said by the blessed prophet with a deep sense and hidden meaning. And there is nothing in the sayings or deeds of any of the prophets that one can justly condemn if one has the knowledge that is in them.

$(\text { Dial. } 112.1-3)^{32}$

Justin is working very hard in this passage to interpret Scripture in a way that offers an alternative to what he considers the dangerous conclusions drawn by his demiurgical contemporaries. This is clear not only from the introductory comments 
about "render[ing] God guilty of every weakness," but also from his emphasis on avoiding the conclusion that Moses was a "transgressor of the Law" (Dial. 112.2) and that he and the other prophets could rightly be blamed $(\mu \varepsilon \dot{\varepsilon} \mu \alpha \sigma \theta \alpha \mathrm{l})$ for their sayings and actions (Dial. 112.3). ${ }^{33}$ When Justin maintains that "there is nothing in the sayings and deeds of any of the prophets which one can justly condemn if one has the knowledge that was in them," he is arguing not against Trypho and his companions, who showed no intention of condemning the prophets, but more likely against demiurgical rivals.

There is good reason to think that Marcion cited this specific example to draw conclusions opposite to those of Justin. ${ }^{34}$ Marcion drew attention to the inconsistency between the proscription of graven images in the Ten Commandments and the divine directive to construct a bronze serpent, which is precisely what Justin addresses both in this passage (Dial. 112) and in Dial. 94. ${ }^{35}$ Moreover, when Justin cited the example of the bronze serpent earlier, he addressed the dangerous effects of misinterpreting such passages. "Will not those (words and deeds) seem contemptible to many people if they are told by those who lack understanding?" he asked in Dial. 92.1. ${ }^{36}$ The sort of people who lack understanding in their interpretation of Scripture are alluded to again in what follows when Justin reiterates that God's actions can only be defended if one assumes that certain things were done because of the disobedience of the Jews (Dial. 92.2). Otherwise, "if this is not the case, God will be falsely accused of not having foreknowledge and of not teaching all people to know and observe the same just notions ... and not true, then, would be the passage that says that God is true and just and that all of his ways are (wise) judgments and that there is no wrongdoing in him" (Dial. 92.5). ${ }^{37}$ In much the same way as in Dial. 23.1-2 (quoted above), Justin frames his interpretation as an alternative to readings of Scripture that conclude that the biblical God is an inferior being, who is not prescient, consistent, true, just, or free from wrongdoing.

Such passages demonstrate that Justin was aware of and influenced by the kind of readings of Scripture proposed by his demiurgical rivals. To be sure, the discussion of the bronze serpent makes some sense on the level of his conversation with Trypho as well, because Justin seeks to convince his Jewish interlocutors that the serpent must be understood as a prophetic reference. Yet the degree of attention that Justin pays to this passage and to the implications of reading this and similar texts in the way Marcion (and perhaps others) did, suggests that Justin has at least one eye trained on his demiurgical rivals. Comparison with Tertullian is again instructive. In Adversus Iudaeos, when addressing a Jewish audience, Tertullian cites the episode of the bronze serpent without any reference to God's perceived inconsistency (10.10). By contrast, Tertullian does address it when the passage first comes up in Adversus Marcionem (2.22.1), where he engages the claim of inconsistency developed by his demiurgical opponent. Justin's focus on this issue and his evident concern to thwart misreadings of this biblical episode that imply divine contradiction suggest that he is trying to do much the same thing that Tertullian seeks to do in Adversus Marcionem, i.e., counteract a demiurgical version of Christianity. 
Justin's concern with Christian demiurgists is evident in other passages also. We noted above that Justin forcefully disputed the existence of "another God" ("a $\lambda \lambda$ o $\theta \varepsilon$ ó $\varsigma$ ) in Dial. 11.1. But later on in the Dialogue he does in fact argue for the existence of "another God," namely Jesus (Dial. 50.1, 56.2, 3, 4, 9, 11 [ä $\left.\lambda \lambda_{0} \varsigma \theta \varepsilon o ́ \varsigma\right]$;

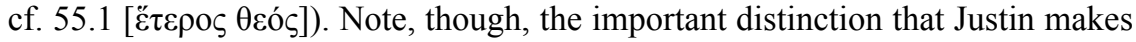
in Dial. 56.4. He writes, "there exists and is mentioned (in Scripture) another God and Lord under the Maker of all things ... above whom there is no other god." ${ }^{38} \mathrm{He}$ makes the same point in Dial. 56.11, when he refers to "the Maker of the world above whom there is no other god." "39 Justin is clearly concerned that his argument could be understood to support those who claim that "there is a certain other God greater than the Creator," to quote his own description of Marcion's teaching in 1 Apol. 26.5. In Dial. 56.11, Justin emphasizes that this other God "never did anything other than what the Maker of the World himself ... wanted him to do or say." 40 Again, the connection with Marcion and other demiurgists who claimed that Jesus's message was at odds with that of the Creator is apparent. The point receives further emphasis when Justin places this disavowal of the demiurgical position in the mouth of Trypho, who is made to say, "We understand that you say that he did not assert, do or say anything contrary to the view of the Maker of All" (Dial. 56.12). ${ }^{41}$ Trypho shows a remarkable level of interest and goodwill upon hearing Justin's rejection of demiurgical notions. Indeed, Trypho claims that the only reason he kept listening to Justin is because of his insistence that there is no one above the Creator and because of his continual references to the Scriptures (Dial. 56.16). The stress placed on this anti-demiurgical point is revealing. ${ }^{42}$

In light of Justin's preoccupation with demiurgical ideas throughout the Dialogue, his repeated insistence that the Biblical God is the "Maker of All" probably had a polemical edge. Judith Lieu rightly cautions that "its ubiquity as a routine epithet for God in the second century means that when found in Christian sources it need not carry any polemical overtones." ${ }^{43}$ Although caution is indeed warranted, I would suggest that when such language is used by an author who is an active opponent of demiurgism, who is writing primarily for an internal audience, and who employs it in the context of explicit comments about rival Christians who questioned that the Supreme God was the Maker of All, it likely does carry polemical overtones (cf. especially Dial. 34.8, 35.5 and 80.4, where the label "Maker of All" occurs in the immediate context of direct references to demiurgical "heresies"). Moreover, Justin regularly employs this and similar phrases when emphasizing the bond between this God and Jesus, insisting that the biblical Creator was truly the Father/Sender of Jesus (Dial. 16.4, 35.5, 48.2, 57.3, $58.1,68.2-3)$, which was a key issue in his dispute with the demiurgists. Justin's repeated emphasis that the God who sent the Messiah is in fact the Maker or Creator of All has no clear function in the conversation with Trypho, but is entirely at home in debates between demiurgical and non-demiurgical Christians.

A particularly notable moment in this connection comes in Dial. 7.3, when the "Old Man," who first introduced Justin to Jesus, speaks in praise of the prophets. He claims that they are 
indeed worthy of belief on the basis of the miracles that they performed given that they glorified God, the Father and Maker of all things and proclaimed Christ, his son, who came from him. The false prophets ( $\psi \varepsilon v \delta о \pi \rho о \varphi \tilde{\eta} \tau \alpha \iota)$ who are filled with a deceiving and unclean spirit neither ever did this nor do so now, but they dare to effect certain miracles to the amazement of people and they worship the spirits and demons of deceit. $^{44}$

In this case, the stress on God as "Father and Creator of All" clearly does have a polemical subtext, because its acknowledgement is construed as a characteristic that distinguishes true prophets from false ones. Both kinds of prophets perform miracles, the Old Man claims, but what distinguishes them is that the false prophets (who are active even now!) do not exalt the Father and Creator of all things and do not proclaim "Christ, his Son, who was sent by him." Who could these still-active false prophets be apart from Justin's contemporary demiurgical rivals? That they are in view is further suggested by Justin's use of the term $\psi \varepsilon v \delta о \pi \rho о \varphi \eta \tilde{\tau} \alpha$ ("false prophets") to refer to the Marcionites, Valentinians, Basilidians and Saturnilians later on in the Dialogue (35.3-5, cf. 82.1-2). He also claims in those passages, as he does here, that they are under the influence of erring and unclean spirits (Dial. $35.2,82.3) .{ }^{45}$

This comment about false prophets fits awkwardly in the context. It is not entirely clear why the Old Man should mention them to Justin at this stage, nor is it evident why Justin should recount this part of the conversation to Trypho. ${ }^{46}$ However, the passage makes excellent sense if we imagine an internal audience faced with the choice between retrospectively orthodox and demiurgical forms of Christianity. It sends a clear message to Justin's readers that they are to trust the prophets who proclaimed Christ and not the false teachers of the present day who fail to exalt the Creator and deny his connection to Jesus.

Other questions that come up in the Dialogue likewise fit the context of this internal debate. Among these is the question of whether Jesus was able to suffer, which Justin revisits a number of times, especially in Dial. 98-105 (e.g., 99.2, 100.2). His attention to this issue make some sense as part of his argument with Trypho, but must surely also be related to the debate on this question among second-century Christians. That Justin is concerned with this debate is strongly suggested by his claim in Dial. 103.8 that scriptural references to the suffering of the Christ were provided "so that we would know that the Father wanted his own Son to be, in reality, in such great pain for our sake and that we would not say that he, because he was the Son of God, did not feel what occurred and what happened to him. ${ }^{\prime 47}$ This theological position was advocated by rival Christians ${ }^{48}$ and was thus of interest to the Dialogue's internal audience (and, conversely, not particularly relevant to a Jewish audience). ${ }^{49}$

It is clear, then, that there are a considerable number of instances in the Dialogue where Justin takes up ideas and interpretations offered by demiurgical Christians. Such moments are not restricted to a particular section of the document; they 
are found throughout the text. Rather than dismissing them as inadvertent leftovers from some hypothetical source that Justin used, I suggest that they are better understood as instances in which the anti-demiurgical force of the Dialogue in its entirety comes more directly to the fore.

\section{Conclusion}

The preceding chapters have argued that Justin had previously been deeply invested in combating demiurgical forms of Christianity, and that he wrote the Dialogue primarily and in the first instance for an internal audience. This chapter explored the possibility that Justin sought to continue these anti-demiurgical efforts when addressing this internal audience in the Dialogue. It is evident that the demiurgists were on Justin's mind when he composed this text from the sections in which he explicitly attacks them, and passages such as Dial. 82.2-3 in which he signals (in the present tense!) that "We are struggling to persuade them not to be deceived, just as with you." 50 The people in view here are the "many who, deviating from the standard, taught atheistic, blasphemous and unjust things in his [i.e., Christ's] name" 51 and who "taught and until now teach the things that have been inserted into their brains by the unclean spirit, the devil." 52 Justin was, at the time of writing of the Dialogue, evidently deeply concerned about such "heretics."

It is not just in isolated passages that this concern is apparent. Virtually all of the topics engaged in this document were relevant to Justin's contestation with the demiurgists. Comparison with later anti-demiurgical writings by Irenaeus and Tertullian confirms that virtually all of what Justin discusses in the Dialogue was immediately relevant to the conflict between demiurgical and non-demiurgical forms of Christianity in the second century. Moreover, this chapter has demonstrated that there are many passages in the Dialogue in which Justin addresses such internal debates rather than (or sometimes, as well as) issues raised by Trypho and the broader Christian encounter with Jews and Judaism.

It is of course true that Justin sometimes draws on demiurgical interpretations of biblical passages to sway his interlocutors to read the text not literally but figuratively and to understand its true meaning in reference to Jesus and his followers. However, such moments provide at the same time a response to the demiurgical readings proposed and debated among Christians in Justin's world. Justin argues around the difficulties identified by Marcion and others in such cases by presenting a figurative reading of these passages. He is regularly so preoccupied with demiurgical ways of reading the text that it is probable that he had an internal audience in mind that was confronted by such interpretations and theologies. Moreover, in addition to marshaling exegetical insights in attempting to persuade his interlocutors to read certain passages figuratively, Justin also positions himself over against rival Christian ideas - or even attacks them outright - when this is not helping him to advocate a figurative reading, and his comments are essentially uncalled for in the context (e.g., Dial. 7.3, 11.1, 56.4, 11, 103.8). It is highly probable therefore that part of the intellectual work that the Dialogue was meant to do was 
to intervene in the internal Christian contestation between demiurgists and retrospectively orthodox Christians. This polemical edge is confirmed by passages in which Justin directly attacks his demiurgical opponents, which will be discussed in Chapter 5. Time and again, Justin positions himself over against demiurgical ideas; as a result the Dialogue in its entirety can be read as an extended argument against demiurgical forms of Christianity. Across and via this treatise, Justin is formulating the "correct" Christian relationship to the Scriptures, the Jewish God, and the Jewish people in conscious negotiation with the alternatives offered by his demiurgical opponents.

\section{Notes}

1 There is some, but not universal, agreement on the basic structure of the Dialogue and thus on the order of major topics: Dial. 1-9 forms the prologue; the next section focuses on the Mosaic Law (Dial. 10-29/47), followed by a discussion of Jesus as the promised Messiah (Dial. 30/48-108); and finally, an argument is proposed for Christians as the New Israel in place of the Jews (Dial. 109-42). All of these major issues are directly pertinent to the debate between demiurgical and non-demiurgical Christians. See Bobichon, Justin Martyr, Dialogue avec Tryphon, 20; Rudolph, Denn wir sind jenes Volk, 71-4, for a helpful overview of scholarly proposals regarding the Dialogue's structure.

2 Justin's employment of these arguments will be analyzed later on in this chapter.

3 Cf., e.g., A.H. 4.34.1.

4 Strikingly, Tertullian sometimes matches Justin's exegesis of such passages verbatim. For instance, in A.M. 3.12-13, Tertullian answers the Marcionite objection that the biblical prophecies do not match the life of Jesus, because according to those prophecies he was supposed to "take up the strength of Damascus and the spoils of Samaria against the king of the Assyrians" (Isa 8:4). The Christ predicted in this passage is a warrior, the Marcionites argued, which does not match the profile of Jesus. Tertullian responds by stating that the Marcionite argument overlooks that this will happen before the child "knows how to say Father, and Mother." Thus, "it follows that the statement must be taken as figurative" (3.13.3). Tertullian then offers the following remarkably creative interpretation: "the strength of Damascus" is the offerings of gold and incense that the infant Jesus received from the Magi, who represent "the spoils of Samaria." The Magi were disobedient to Herod, who is labeled in Isaiah "the king of the Assyrians." Significantly, Justin offers the very same explanation in Dial. 77.2-78.10 (note, moreover, that both cite Ezek. 16:3 in this connection, which is not an obvious text to mention here [Dial. 77.4; A.M. 3.14.9], and that both discuss how Damascus was formerly part of Arabia, even though it now belongs to Syro-Phoencia [Dial. 78.10; A.M. 3.13.8]). This suggests the possibility that like Tertullian, Justin was also offering this interpretation in response to a Marcionite/demiurgical reading of Isa. 8:4. Of course, it is possible that rather than being an actual Marcionite objection, Tertullian simply invented this position in order to demonstrate that he could easily refute the Marcionites. If so, neither Tertullian nor Justin would have been engaging any actual Marcionite arguments. The difficulty with this solution, however, apart from the perhaps rather too extreme skepticism it requires, is that Tertullian is not offering a very convincing response to the Marcionite argument. If he were setting up a straw man, we would expect him to invent something to which he could offer a forceful and decisive response, not the sort of fanciful exegetical solution he offers here. More likely, then, Tertullian's report is reliable on this point, at least in broad outline. Indeed, one could easily see how this verse would attract Marcionite interest given that it seems to depict the promised redeemer as 
a military, bellicose figure, much like the Marcionite Creator (cf. A.M. 3.14). For further discussion of parallels between Justin and Tertullian, see Gilles Quispel, De bronnen van Tertullianus'Adversus Marcionem (Leiden: Burgersdijk \& Niermans, 1943), 56-9.

5 This entails a certain degree of "mirror-reading." However, whereas with, e.g., the letters of Paul we have to rely exclusively on the letters to reconstruct the opposition, in the case of the Dialogue we have a variety of sources that inform us about Justin's contemporary Christian context. When Justin offers arguments against a view that we know from other sources was actually held by other contemporary Christians, we are on much more solid ground than if we had to make inferences solely on the basis of Justin's text alone (as is often necessarily the case with earlier Christian texts). This corroborative evidence is far from perfect: ideally we would have access to the writings of Justin's rivals, instead we often have only the writings of their opponents.

6 Hans von Campenhausen, Die Entstehung der christlichen Bibel (Tübingen: Mohr Siebeck, 1968), 112 n. 174.

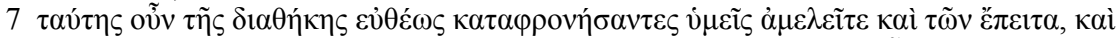

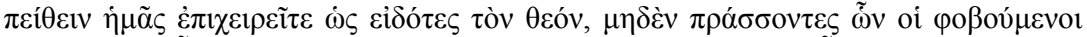

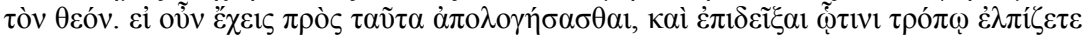

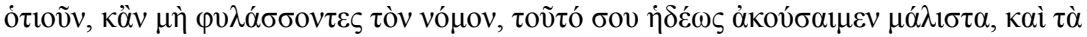

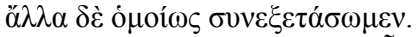

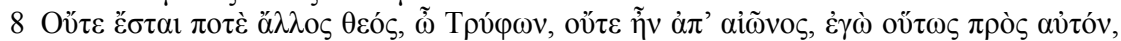

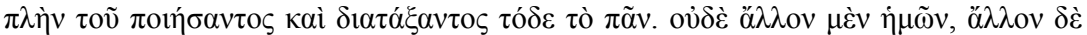

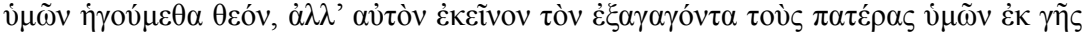

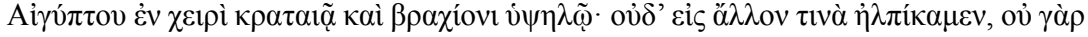

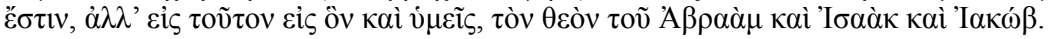

9 Stylianopoulos, Justin Martyr and the Mosaic Law, 25.

10 Ibid., 31, claims that Justin "poses marcionite-inspired problems of the Old Testament and the Law to Trypho, and then answers them himself," suggesting that while such issues may have their background in anti-demiurgical debates, they are now used in a way that is entirely suitable to the debate between Jews and Christians. Such a characterization does not work well in this and other instances; Justin introduces something that is essentially irrelevant from Trypho's point of view.

11 Justin's negative description of the Jewish people as "hardhearted" and oblivious to the truth, then, may be seen as a direct result of the challenge posed by the "heretics." It is born out of the need to defend God's unity and consistency in light of the changes in divine legislation. Conversely, Marcion and other demiurgists do not appear to have felt quite the same need to disparage Jews. For further discussion, see Pieter Gotfried Verwijs, Evangelium und neues Gesetz in der ältesten Christenheit bis auf Marcion (Utrecht: Kemink, 1960), 289; David Efroymson, "The Patristic Connection," in Antisemitism and the Foundations of Christianity, ed. Alan T. Davies (New York: Paulist Press, 1979), 98-117; Stephen G. Wilson, "Marcion and the Jews," in Anti-Judaism in Early Christianity. Vol. 2: Separation and Polemic, ed. S.G. Wilson (Waterloo, ON: Wilfrid Laurier University Press, 1986), 45-58; Wilson, Related Strangers, 195-222; Heikki Räisänen, "Marcion and the Origins of Christian Anti-Judaism. A Reappraisal," Temenos 33 (1997): 98-117; Joseph B. Tyson, "Anti-Judaism in Marcion and His Opponents," Studies in Christian-Jewish Relations 1 (2005-2006): 196-208.

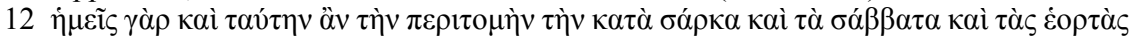

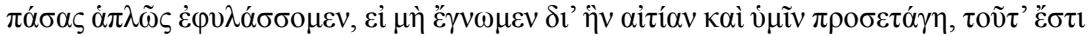

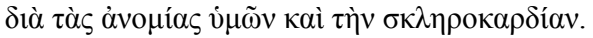

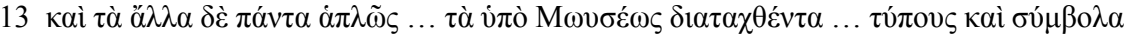

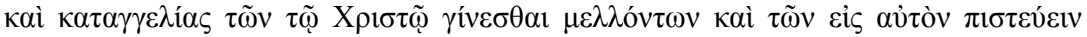

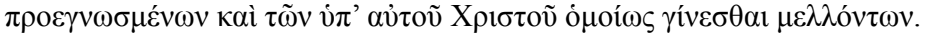

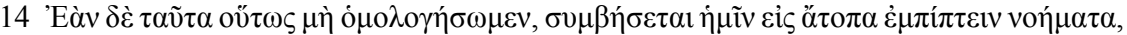

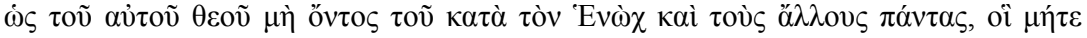




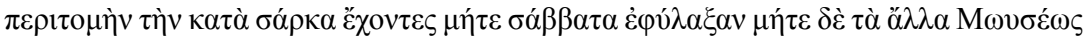

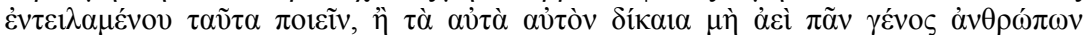

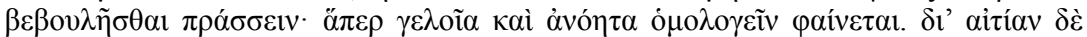

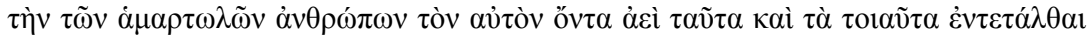

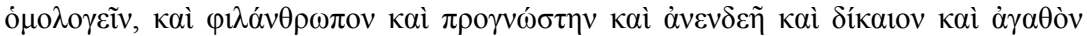

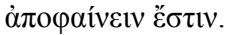

15 Compare Justin's response to the question of why Christians do not keep the Mosaic Law to that of Tertullian. In Adversus Iudaeos, Tertullian argued that the Mosaic Law was itself preceded by other and more fundamental laws and cites passages from the Old Testament predicting the appearance of a New Law as well as passages critical of Mosaic rites such as circumcision and Sabbath. Tertullian's focal point is that the Mosaic Law is temporal rather than eternal. Significantly, questions regarding God's unity, singularity, consistency and goodness do not come up in this context. This is not necessary, because in this treatise Tertullian is unconcerned about demiurgical arguments. Conversely, however, when he is concerned with demiurgical notions, in Adversus Marcionem, all of these issues do come to the fore. Tertullian's disinterest in questions of God's consistency in $A d v$. Iud. also allows him to avoid emphasizing the Jews' hardheartedness to explain the change in God's legislation (cf. Dunn, Tertullian's Aduersus Iudaeos: A Rhetorical Analysis, 52-3, who notes that anti-Jewish polemic is significantly more prominent in $A d v$. Marc. than in $A d v$. Iud.). This relative absence of harsh polemic against the Jews is entirely fitting for an argument that has as its sole focus demonstrating the superiority of "Christianity" over against "Judaism"; conversely, the presence of such vituperations in the Dialogue suggests that rather more is going on in this text (more on this in Chapter 4).

16 Winrich A. Löhr, "Did Marcion Distinguish Between a Just God and a Good God?," in Marcion und seine kirchengeschichtliche Wirkung = Marcion and his impact on church history: Vorträge der Internationalen Fachkonferenz zu Marcion, gehalten vom 15.-18. August 2001 in Mainz, ed. Gerhard May, Katharina Greschat, and Martin Meiser (Berlin; New York: Walter de Gruyter, 2002), 137, points out that Irenaeus credits Cerdo, but not Marcion with a distinction between a just god and a good god (A.H. 1.27.1). Marcion's inferior god is described as malus and malorum factor (A.H. $1.27 .2 ; 3.12 .12)$. Löhr concludes, after reviewing the evidence from Tertullian, Clement of Alexandria, Origen and Hippolytus: "Even if Marcion had indeed designated the god of the Old Testament as 'just,' it would have been only an abbreviation for his being a severe and cruel judge, a petty-minded and self-contradictory legislator" (144). According to Sebastian Moll, The Arch-Heretic Marcion, WUNT 250 (Tübingen: Mohr Siebeck, 2010), 47-76, Marcion's god is simply evil. Such dualism is regarded as a later development by Lieu, Marcion and the Making of a Heretic, 343-9. See also Enrico Norelli, "Un 'Dieu bon' agressif et haineux ? Le Marcion discutable de Sebastian Moll," JEH 65 (2014): 347-53. In this connection, it is not insignificant that Justin places considerable emphasis on Jesus's role as judge (see Bobichon, Justin Martyr, Dialogue avec Tryphon, 1000-1) and is capable of mentioning in one breath Jesus's justness and God's goodness (Dial. 47.5).

17 For Marcion and others the Creator is not $\varphi \imath \lambda \alpha \dot{\alpha} v \theta \rho \omega \pi \circ \varsigma$ because he has placed humanity in an imperfect world that he rules inconsistently and even cruelly. His lack of $\varphi 1 \lambda \alpha v \theta \rho \omega \pi i \alpha$ is also evident from the Creator's preference for the Jews as opposed to the rest of humanity (cf., e.g., Irenaeus, A.H. 1.24.4 on Basilides: "he [the Creator] wished to subject the rest of the nations to his people, that is, to the Jews ..."). On the Creator not being prescient or needful of nothing, see the next paragraph.

18 It seems more plausible that Justin is concerned with Christian demiurgists than with the people mentioned in rabbinic literature who adhered to the notion of "two/many powers in heaven" (e.g., m. Sanh. 4.5, Sifre Deut. 329; Mekhilta de-R. Ishmael Ba-Hodesh 5, Shirta 4), although some degree of overlap between the two groups certainly is possible. 
Inconsistency in legislation does not seem to have played much of a role in the debate between the rabbis and adherents of "two powers," but this was centrally important to the debate among Christians (cf. Marcion, Ptolemy, etc.).

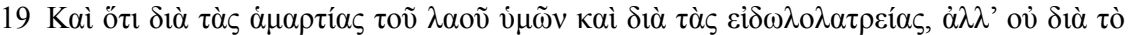

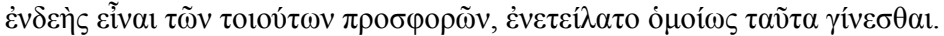

20 Cf. Dial. 22.11, where Justin reiterates that God does not need sacrifices and adds that God also did not need "a house or a court."

21 It would be difficult to improve upon Ernest Evans's lucid translation of Adversus Marcionem (Oxford: Clarendon Press, 1972), which I follow here and in subsequent quotations from $A . M$.

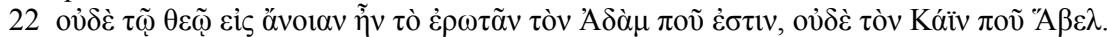

23 Tertullian discusses God's questions to Adam and Abel as part of his polemic against Marcion in A.M. 2.25. On God's prescience more generally: A.M. 2.5.1-4. See also, with regard to God's question to Adam, On the Origin of the World 119, 26f.; Hypostasis of the Archons 90, 19-21, TestTruth NH IX.3 47.14-29, and cf. Theophilus, Ad Autolycum, 2.26. In asking such critical questions, they may have drawn on earlier precedents (see, e.g., Philo, $Q G$ I.45).

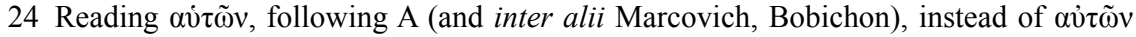
(Goodspeed).

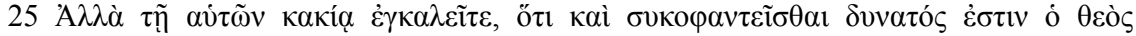

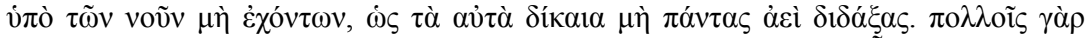

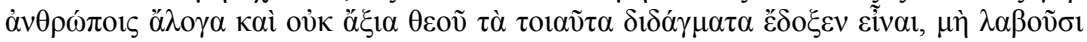

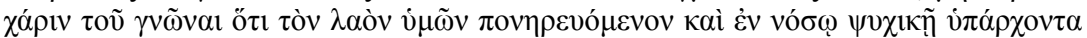

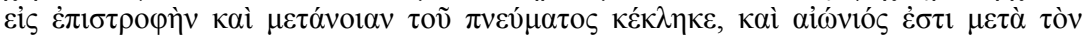
M

26 Justin intimates that the Jews are on some level responsible for such Christian "heresy." Chapter 5 of the present study argues that he develops this argument in more detail elsewhere.

27 See, e.g., Lieu, Marcion and the Making of a Heretic, 357-66.

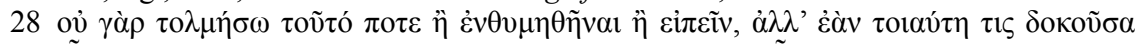

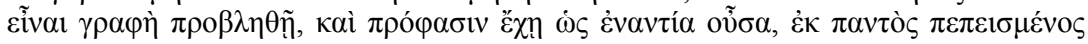

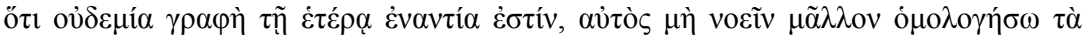

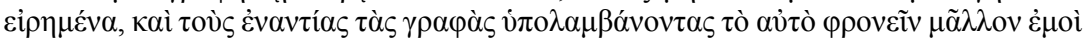

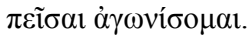

29 Another appearance of Justin's Christian rivals may perhaps be detected in Dial. 141.2: "When someone repents of his sin, he will receive forgiveness of his sins from God, but not, as you say, deceiving yourselves, and others who are like you in this regard say, that even though they are sinners, because they know God, the Lord would not

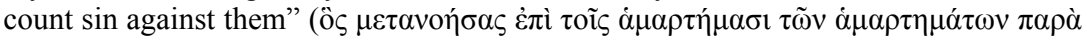

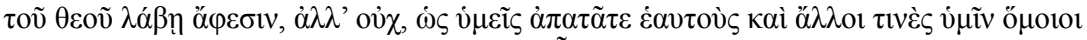

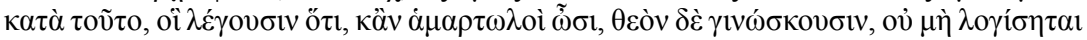

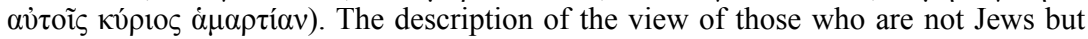
similar to them in this regard, makes good sense as an unsympathetic summary of the close connection between knowledge and salvation posited by various Christian demiurgists. Cf., e.g., out of many possible comparanda, Irenaeus's similarly unsympathetic account of the Valentinians, where he claims that they say that "[we, i.e., the retrospectively orthodox] do not have perfect knowledge ... so they declare that good conduct is necessary also for us ... they themselves [the Valentinians], however, so they dogmatize, are spiritual, not by conduct, but by nature, and so will be saved entirely and in every case ..." (A.H. 1.6.2). This coheres to a considerable degree with what the "others who are like you in this regard" teach according to Justin.

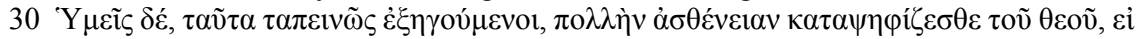

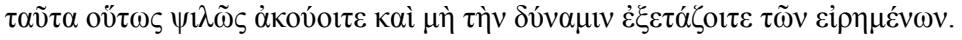


31 Accusations of "wooden literalism" are of course polemical stock items. Whether Marcion consistently employed a more literalist hermeneutic than figures such as Justin did is debatable (and surely too one-dimensional a way of framing the question).

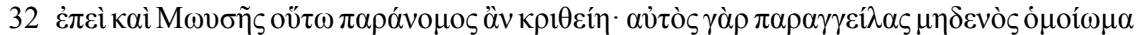

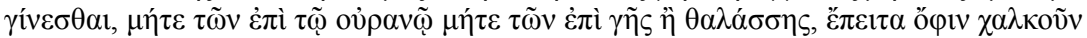

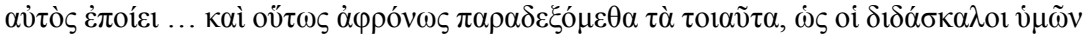

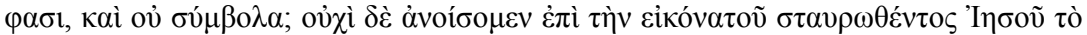

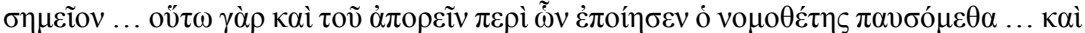

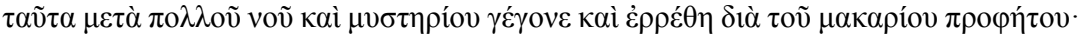

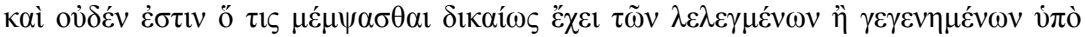

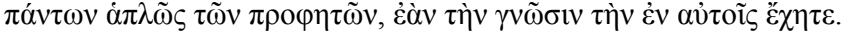

33 Cf. Dial. 94.4-5.

34 See, e.g., Tertullian, A.M. 2.22; Lieu, Marcion and the Making of a Heretic, 358-62; Moll, The Arch-Heretic Marcion, 81.

35 "Moses would thus be judged a transgressor of the Law; because having commanded that no likeness should be made of anything either in heaven or on the earth or in the sea, he himself made a bronze serpent" (Dial. 112.1); "Was not God the one who gave the commandment, through Moses, not to make an image or a likeness ... yet he himself effected

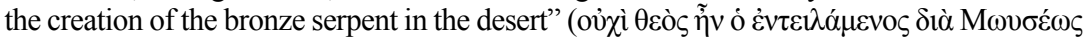

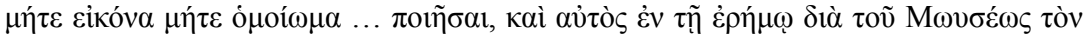

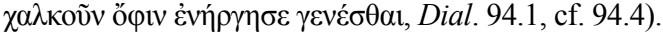

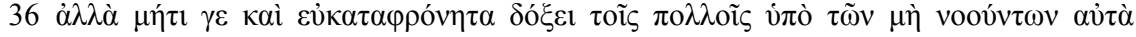
$\lambda \varepsilon \gamma o ́ \mu \varepsilon v \alpha$.

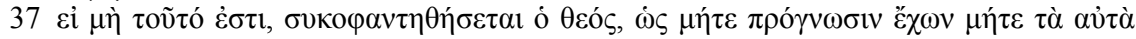

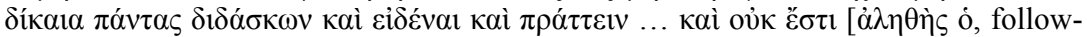

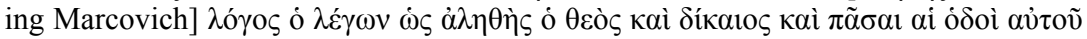

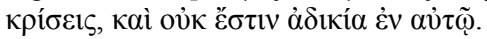

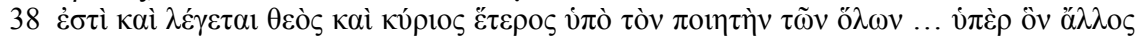

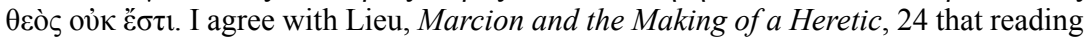
$\pi \alpha \rho \alpha ́$ for vं $\pi$ (so, e.g., Marcovich) is unnecessary. I do not, however, follow her rendering of the phrase according to which the "other God" "is called God by the maker of all" (emphasis original). When it introduces an agent, vंó is followed by a genitive, not by an accusative (as it is here). With the accusative it normally means "under" or "below" (BDAG 1036), a reading supported here by the contrast with $v \pi \varepsilon \dot{\rho} \rho(+a c c=$ "over and above," "beyond," etc. [BDAG 1031]).

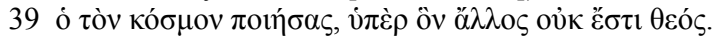

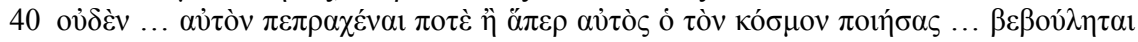

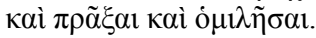

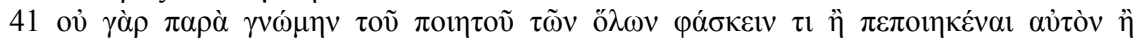

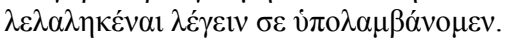

42 On Dial. 56-60 as aimed against Marcion, see Skarsaune, The Proof from Prophecy, 206-13, who believes Justin "has probably presented [the argument] for the first time in his anti-Marcion Syntagma" (212), but suggests that it retains anti-Marcionite force in the present context. Cf. also Oskar Skarsaune, "The Development of Scriptural Interpretation in the Second and Third Centuries," in Hebrew Bible/Old Testament: The History of Its Interpretation I/1: Antiquity, ed. Magne Sæbø (Göttingen: Vandenhoeck \& Ruprecht, 1996), 407-9, 415-17, 427-9.

43 Lieu, Marcion and the Making of a Heretic, 332.

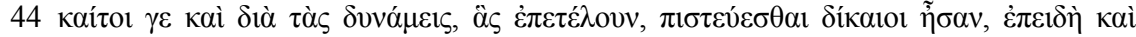

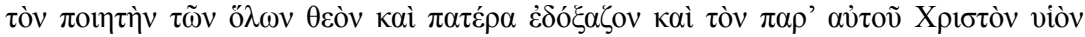

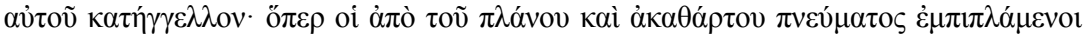

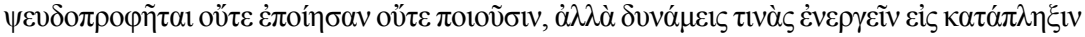

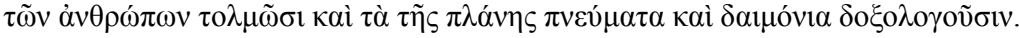


$45 \mathrm{Cf}$. also the performance of miracles by "heretics" reported in 1 Apol. 26.1-4, 56.1, another element shared with Dial. 7.3.

46 It is clear from Dial. 8.1 that Justin has been selective in his reporting of this meeting (whether it was fictional or not is beside the point).

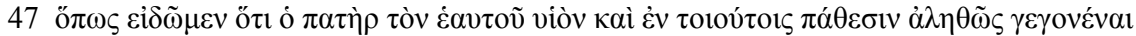

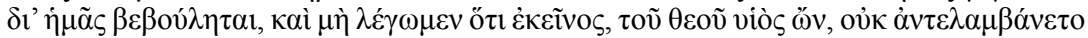

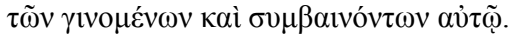

48 Cf., e.g., Irenaeus, A.H. 1.7.2 (Valentinians), 1.24.4 (Basilides), 1.26.1 (Cerinthus). Note, however, that the specifics of Irenaeus's claims are debatable. The evidence from Nag Hammadi suggests a different, more nuanced picture. See, e.g., Karl-Wolfgang Tröger, "Doketistische Christologie in Nag-Hammadi-Texten. Ein Beitrag zum Doketismus in frühchristlicher Zeit," Kairos 19 (1977): 45-52; Frederick Wisse, "The 'Opponents' in the New Testament in Light of the Nag Hammadi Writings," in Colloque international sur les textes de Nag Hammadi, Québec, 22-25 août, 1978, ed. Bernard Barc (Québec: Les Presses de l'Université Laval, 1981), 117-19; Jean-Daniel Dubois, "Le docétisme des christologies gnostiques revisité," NTS 63 (2017): 279-304. Marcion was also accused of docetism (e.g., Tertullian, A.M. 3.8.5: "the sufferings of Marcion's Christ will fail to find credence: one who has not truly suffered, has not suffered at all, and a phantasm cannot have truly suffered"), but whether this is an accurate representation of Marcion's views is doubtful. See David E. Wilhite, "Was Marcion a Docetist? The Body of Evidence vs. Tertullian's Argument," VC 71 (2017): 1-36.

49 The question of Jesus's suffering is closely related to the question of whether he was born a man (i.e., took on real human flesh). The nature of Christ's birth was debated among contemporary Christians such as Marcion, Apelles and Valentinus (cf., e.g, Tertullian, De carne Christi 1.1) and this may form the background for Justin's remarkable emphasis on the virgin birth of Jesus, a topic that reccurs throughout the Dialogue (23.2, 43.1-8, 45.4, 48.2, 50.1, 66.1-4, 84.1-2, 120.1, 127.4, etc.).

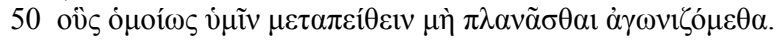

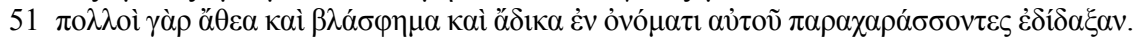

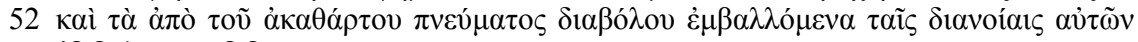

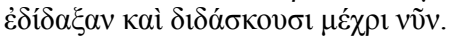




\section{4 \\ "HERESY" AND THE \\ COMPOSITION OF THE DIALOGUE}

Justin's concern with rival Christian theologies in the Dialogue raises questions about the literary format of the text: Why were the anti-demiurgical arguments identified in the previous chapter developed in the framework of a conversation with Jews? Why did Justin choose the specific literary format of a dialogue between a Jew and a Christian as his vehicle? And, closely related to this, how does the Jewish-Christian encounter presented in the Dialogue relate to Justin's anti-heretical efforts? It is of course possible to suppose that Justin pursued two essentially unrelated goals: evangelize Jews and attack demiurgists. This chapter suggests that rather than unrelated efforts, these goals were intimately connected for Justin, and not simply because both demiurgists and Jews denied the validity of the proof-from-prophecy. I argue that the conversionary drive as well as many other features of the Dialogue can be explained adequately by situating the document in the context of internal Christian debate. These features, many of which have puzzled scholars in the past, include the lack of conversion at the end of the Dialogue, its strange juxtaposition of evangelistic intent with harsh denunciation, Trypho's remarkable openness to Justin's arguments, the literary setting shortly after the Bar Kochba revolt, and the introductory section's focus on philosophy. In short, this chapter demonstrates how situating the Dialogue in the debate between demiurgical and retrospectively orthodox Christians better explains various key aspects of the Dialogue, without, however, denying Justin's evident interest in persuading non-Jesus-believing Jews of the truth of his Christian message.

\section{A remarkable ending}

Let us begin at the end. Whereas later literary dialogues between a Jew and a Christian routinely conclude with the conversion of the Jewish interlocutor, Justin's Dialogue ends with neither Trypho nor any of his friends being persuaded, and this after two full days of discussion: ${ }^{1}$

After Trypho was quiet for a while, he said: "You see that we conversed about these matters not as the result of any concerted effort. I do admit that I greatly enjoyed our discussion, and I suspect that they (my friends) 
are similarly disposed, for we have found out more than we expected and more than ever could be expected. If we did this more frequently, we would benefit even more from examining the Scriptures."

"But since," he said, "you are about to set sail and expect to commence your voyage any day now, do not hesitate to remember us as friends when you set off."

"As far as I am concerned," I said, "if I stayed here I would like for this to happen every day, but since I expect to set sail right away, with God's will and help, I urge you, as you undertake this great struggle for the sake of your own salvation, to endeavor to honor the Christ of Almighty God more than your own teachers."

After this they departed, finally wishing me safety during the voyage as well as (deliverance) from every evil. And I gave them my well-wishes and said, "I cannot wish for anything greater for you, gentlemen, than that, realizing that it is given to every person to be prosperous through this way, you yourselves will believe without doubt like we do that ours is the Christ of God."

(Dial. 142.1-3) $)^{2}$

This final passage is somewhat ambiguous. While Trypho and his friends do not flat-out reject Justin's message, there is also no suggestion that they wish to convert or are even close to converting. Some have argued that there is a subtle hint of hope that Trypho will change his mind later on when he has had time to fully absorb Justin's many arguments. ${ }^{3}$ This theory is based on the Dialogue's account of Justin's own conversion, according to which Justin accepted the Old Man's views after their conversation had drawn to a close (Dial. 8.1). Perhaps, then, Justin sought to convey that Trypho too was likely to change his mind at some point subsequent to their meeting. This line of argument finds some support in two passages not previously considered. In Dial. 74.2, Justin mentions that the meaning of various scriptural passages may be grasped "when you are by your-

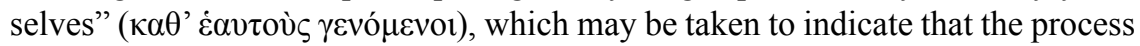
of understanding scriptural truth will take place only after their meeting has concluded. Additionally, in Dial. 68.2, Trypho indicates that carefully studying all the scriptural evidence will be a lengthy process. "After much trouble and toil," he writes, "you were able to grasp these things, we also, therefore, will have to agree to what the Scriptures compel us to accept after we have examined closely all that meets us." ${ }^{4}$ This prepares the reader for the idea that Trypho will only be ready to accept Justin's reading of Scripture after some time. But even so, the ending of the Dialogue is preceded by so many complaints about the stubbornness and hardheartedness of the Jews that Justin's readers would hardly be optimistic about the fate of Trypho and his companions (we return to this point below).

Justin's failure to win any outright converts during the two-day discussion was not for lack of trying. As mentioned earlier, Theodore Stylianopolous has drawn 
attention to Justin's apparent interest in converting Jews. Indeed, there are several passages that convey this impression (e.g., Dial. 28.2-3, 32.2, 35.8, 44.1, 92.6, 96.3, 142.2-3). ${ }^{5}$ Primarily on this basis, Stylianopoulos concluded that the Dialogue must have been written for a Jewish audience. But if this really were a text written to evangelize Jews, would we not expect at least some of the Jews in the text to be unambiguously persuaded by the end? ${ }^{6}$ And yet, even if we take the position that the Dialogue was primarily written for an internal audience (as argued in Chapter 2), the disconnect between Justin's evangelistic intent and the failed outcome remains puzzling. ${ }^{7}$

Further complicating the issue is that despite Justin's stated desire to win over the Jews, the Dialogue features many passages in which he refers to them in harsh terms. To give but a few examples: "you are a hardhearted people, stupid, blind and lame, children in whom there is no faith" (Dial. 27.4), "[you Jews] have never wanted to understand or do the things of God"9 (Dial. 48.2); "[you Jews] were commanded to observe the Sabbath [etc.] ... so that ... you might not by worshipping idols and forgetting God become impious and godless, as indeed, you appear to have always been"10 (Dial. 92.4); "God does not want you to always remain stupid and selfish as you are now"11 (Dial. 92.6); "you always appeared ungrateful, and murderers of the just, and filled with insane arrogance because of your ethnicity"12 (Dial. 102.6); "you are a foolish and hardhearted people ... for you are neither wise nor intelligent, but sly and deceitful"13 (Dial. 123.4). Such passages have often been overlooked (or ignored) by scholars, some of whom have characterized the Dialogue as an essentially civil or even friendly exchange. ${ }^{14}$ In reality, there are quite a few instances of unforgiving polemic that stand at odds with any real attempt to win over a Jewish audience. To alleviate this tension, some interpreters have read such polemic as directed at the Jews in general rather than at Trypho and his friends, but such a distinction is unsustainable. ${ }^{15}$ A particularly revealing moment in this connection is Dial. 78.10-79.2, where Justin accuses "you" (plural, i.e., Trypho and his companions, and perhaps the Jews more generally) of "making every effort to assert your own teachings while dishonoring those of God" (Dial. 78.10). ${ }^{16}$ Immediately following, Trypho is said to have "become somewhat angry" (vं $\alpha \gamma \alpha v \alpha \kappa \tau \tilde{\omega} v$ [Dial. 79.1]), to which Justin responds, "Wanting to dispose him to listen to me favorably, I answered in a much milder tone" (Dial. 79.2). ${ }^{17}$ Although Trypho is particularly upset about Justin's "blasphemous" interpretations (79.1), his indignation surely has to do with Justin's immediately preceding insults as well. This passage suggests that Justin was fully aware that harsh polemic would thwart a favorable hearing of his message, which makes it all the more curious that he engages in such polemic throughout the conversation. The Dialogue, then, presents us with a remarkable mix of harsh polemic, conversion attempts, and a failure to obtain much in the way of real results.

The plot thickens still more. Despite Justin's failure to convert Trypho and his scolding of Trypho individually and all Jews generally, there are many moments 
where Trypho or his friends actually do accept Justin's arguments. Trypho and his companions are convinced by Justin's claims at many points:

"It may also be admitted that these things are as you say, and that it was prophesied that Christ would suffer"

$(\text { Dial. 36.1 })^{18}$

"Demonstrate now that he exists, so that we can agree also on this"

$\left(\right.$ Dial. 56.12) ${ }^{19}$

"It appears that Scripture compels us to agree with this"

$(\text { Dial. 57.1 })^{20}$

“'My friend,' said Trypho, 'this has been demonstrated by you forcibly and with many arguments"”

(Dial. 63.1) $)^{21}$

"I admit that your arguments are so numerous and forceful that they suffice to convince"

$(\text { Dial. 77.1 })^{22}$

"we agree that all the Scriptures that you have cited refer to him ... it is evident that the Scriptures proclaim that Christ was to suffer"

(Dial. 89.1-2). ${ }^{23}$

Other examples could be cited (cf. Dial. 39.7-8, 50.1, 58.10, 60.3, 64.1, 65.7, 67.8-11,89.1,90.1, 130.1), but the passages quoted will suffice to make the point. Such moments of assent on the part of Trypho and his companions, if they are recognized at all, have often been explained as "mere" rhetorical devices meant to move the conversation in a direction that Trypho considered more worthwhile. ${ }^{24}$ Although this is no doubt sometimes the case, such an explanation fails to do justice to the substantive agreements that Trypho and his friends express. Sometimes Trypho merely responds in a friendly, noncommittal way (e.g., Dial. 55.1, 80.1), and sometimes he and his friends simply fail to offer a retort (e.g., Dial. 23.2-3, $121.1,137.3)$. But at various points he quite unambiguously expresses agreement with Justin on central issues. For example, Trypho accepts that the Christ would have to suffer and that he would come twice: once in suffering and once in glory (Dial. 36.1, 39.7-8); that Elijah would be the forerunner at the second coming (Dial. 49.2) and that Elijah's spirit was already present in John the Baptist (Dial. 49.3-50.1); that there is "another God" (i.e., Jesus) in addition to the Creator, who is distinct from God "in number, but not in mind" (Dial. 57.1, 60.3, cf. 55.1, $56.11-12,58.10,129.3-130.1)$; that it is proper for the Gentiles to profess Jesus as "Lord and Christ and God, as the Scriptures signify" (Dial. 64.1); that God shares his glory with Christ (Dial. 65.7, cf. 65.1); that some precepts of the law were 
issued only because of Jewish hardheartedness (Dial. 67.10-11); that the "other God" was born "man of a virgin" and that the Christ was therefore of divine nature (Dial. 77.1, cf. 75.1-76.7); that the name of this Christ would have to be Jesus (Dial. 89.1); and that the Christians are the New Israel (Dial. 123.7). Importantly, the consistent basis for this agreement is Justin's argument from Scripture. As Trypho states in Dial. 89.1-2, "we agree that all the Scriptures that you have cited refer to him [i.e., Christ]."

To be sure, Trypho does vehemently protest Justin's claims at points. But this often happens halfway through the discussion of a given topic. Trypho's protestations thus allow Justin to develop his argument further or from a different angle, often with the result that Trypho accepts Justin's claims. Trypho regularly responds dismissively at first, but after Justin has explained his position, Trypho frequently accepts it or remains quiet. Once Justin has presented his arguments in full, Trypho does not usually register complete disagreement.

The most important issue on which Trypho withholds assent is the notion that the Messiah had to die by crucifixion, even though he does accept that the Messiah had to suffer. Trypho expresses his objection to the cross forcefully in Dial. 89.1-2 and Dial. 90.1. Importantly, though, this is before Justin presents his argument that the cross has been foreshadowed in Scripture. After he provides the evidence for this claim, we hear neither approval nor rejection from Trypho. In fact, Trypho is relegated to the status of an audience member until Dial. 118.5. When he does finally get to speak again, it is only to signal that Justin should repeat some things if he wants to; we get no rejoinder to Justin's arguments. Subsequently we do hear of a brief scuffle with some of Trypho's companions in Dial. 122.4, and in 123.7 Trypho asks a question, but again only to prompt Justin to repeat some of what he has said before for the sake of those who arrived later (cf. Dial. 123.8). Justin mentions multiple times that his interlocutors "remain silent" in response to his claims (Dial. 121.1, 137.3). However, this is essentially the only form of response (or rather, lack thereof) that is offered between Dial. 90 and the final chapter (Dial. 142). It is not the case that Justin veers off into monologue to such an extent that he loses track of the dialogical setting of the text, because he continues to address his interlocutors directly at various points (Dial. 119.1, 120.4, 121.1, 124.1, 125.1, etc.). Nevertheless, there is a noticeable shift from dialogue to pseudo-monologue in these final chapters and this is yet another remarkable characteristic of the Dialogue that requires explanation. What is most important at the present point, however, is that while Trypho does not express agreement with Justin's argument that the Messiah had to die on the cross, he also does not signal any disagreement after Justin has presented his evidence.

Whereas toward the end of the Dialogue we get no response from Trypho at all, in the text's earlier sections (i.e., prior to Dial. 90), Trypho and his companions express considerable agreement with Justin, as we have seen. Such openness to Justin's claims is difficult to square with his harsh comments about the Jews, and especially with his frequent accusations of their misunderstanding and unwillingness to learn. To give an example of the sort of charge Justin hurls time and again, 
in Dial. 114.5 he says to Trypho and his companions, "you do not understand what I say, because you did not understand the things that were prophesied Christ would do, and you do not believe us when we refer you to the Scriptures." ${ }^{25}$ Yet clearly, Trypho does believe Justin at key points. Even though Trypho is remarkably receptive to Justin's explanations, the latter rarely grants that his interlocutor is making a good faith effort to further his understanding. Especially in the final part of the Dialogue, Justin repeatedly makes statements such as "you are lying and are attempting to deceive yourselves"26 (Dial. 117.4), and "it would be better to stop being argumentative" (Dial. 118.1, cf. 123.7). ${ }^{27}$

This results in an odd combination of willingness to listen and learn on Trypho's part and Justin's accusations to the contrary. For instance, in Dial. 113.1, Justin is speaking about the name change from Hosea to Joshua/Jesus (cf. Num 13:16), when he begins to scold Trypho:

You do not investigate why he did this, nor do you contemplate the matter or care to inquire. Therefore Christ has escaped you. When you read you do not understand, and, even now, when you hear that Jesus is our Christ, you do not figure out that he was given this name deliberately and not accidentally. ${ }^{28}$

These comments are rather unexpected in context. Trypho and his companions had been patiently listening to Justin for the better part of two days, and had in fact already heard Justin's explanation of the significance of this name change multiple times. As Justin himself notes at the beginning of Dial. 113.1: "Jesus, as I said many times before, was called Hosea." ${ }^{29}$ Moreover, Trypho intimated in Dial. 89.1 that he found Justin's argument on the basis of this name change compelling. Justin's accusation of unwillingness to investigate and contemplate the matter makes little sense. Indeed, just a little while later, Trypho forgives Justin's penchant for repetition, saying, "That is no problem ... but even if you were to say the same things again at greater length, you should know that I and those present here with me will gladly listen" (Dial. 118.5). ${ }^{30}$ Trypho is nothing if not extremely patient with Justin and apparently deeply interested in and open to what he has to say. He even encourages Justin to repeat some things for the benefit of those who joined later in Dial. 123.7-8. I would wager that few readers can honestly echo Trypho's sentiment that they would gladly listen much longer to what Justin has to say. (At this point we have reached page 214 of the Greek text in Marcovich's edition!) Taken together, these inconsistencies hint that more is going on than what is apparent on the surface of the text.

\section{Jews, demiurgists and a failed mission}

Taking seriously the intellectual context in which Justin composed the Dialogue is key to unraveling this curious combination of seemingly inconsistent literary strategies. In the preceding chapters, I argued that Justin was preoccupied with "heresy," 
particularly that of the demiurgical variety, over the course of his career. Accordingly central to Justin's argument in the Dialogue is the notion that the Jewish Scriptures do not attest an inferior divinity essentially unrelated to Jesus, but that they predict Jesus's ministry. Consequently, the reality that very few Jews recognized Jesus in their own Scriptures was a significant problem. Exactly how many Jews regarded him as the Messiah around the middle of the second century is unclear because of the fragmentary nature of the historical record, but there probably were not very many. In the mid-first century, the apostle Paul had recognized this as a theological problem (cf. Romans 9-11), and there is no reason to think that much had changed in the century or so between Paul and Justin. Scholars debate the precise number and percentage of Jewish believers in Jesus, but virtually all agree that the great majority of Jews rejected the Christian claim that he was the Messiah. ${ }^{31}$

What, then, could be a more powerful argument against Justin's arguments, founded as they were on the Jewish Bible, than the fact that so few Jews agreed with him? How persuasive could the proof-from-prophecy really be if the vast majority of Jews did not recognize Jesus in their own Scriptures? It is difficult to imagine that the failure of Jews to convert would not have been cited by demiurgists against the retrospectively orthodox claim that the Scriptures "clearly" speak of Jesus. Indeed, Tertullian indicates that this objection was raised by demiurgical Christians:

heretical madness ... was compelled to form an alliance with Jewish error, and from it to build up an argument for itself, on the pretext that the Jews, assured that he who has come was an alien, not only rejected him as a stranger but even put him to death as an opponent, although they would beyond doubt have recognized him and have treated him with all religious devotion if he had been their own.

According to Tertullian, the failure of the Jews to recognize Jesus as the Christ predicted in their Scriptures formed the pretext for the Marcionite rejection of any connection between Jesus and the God of the Jewish Scriptures. Tertullian responds to this with characteristic rhetorical flair:

It can have been no Rhodian [i.e., a reputable] law, but a Pontic one, which assured this shipmaster [i.e., Marcion from Pontus] that the Jews were incapable of making a mistake respecting their Christ; although, even if nothing of this sort were found to have been spoken in prophecies against them, human nature alone and by itself, wide open to deception, might have persuaded him that the Jews could have made a mistake, being men, and that it would be wrong to use as a precedent the judgement of persons who had likely enough been mistaken. But seeing there were also prophecies that the Jews would not recognize Christ and would therefore destroy him, it at once follows that he who was unrecognized 
by them, he whom they put to death, is the one whom they were marked down beforehand as going to treat in this fashion.

Tertullian's reply again confirms our main point that demiurgists (Marcionites in this case) cited the failure of the Jews to accept Jesus as the prophesied Christ in support of their own views. To their mind this clearly indicated that Jesus was not the one predicted in the Jewish Scriptures.

Tertullian's response consists of two parts. First, he argues that the Jews' failure can be explained as due to human error. Much more interesting and potentially forceful, however, is the second part of Tertullian's reply, in which he refers to "prophecies that the Jews would not recognize Christ." Rather than an argument in support of the claim that the Jewish Scriptures did not predict Jesus, the rejection of the Jews is taken as confirmation of the reliability of said Scriptures, because they predicted the very rejection that is now taking place. According to Tertullian's argument, the failure of the Jews to accept Jesus as Messiah did not threaten the validity of biblical prophecy. To the contrary, their failure confirmed it.

This passage from Tertullian indisputably demonstrates that the failure of the Jewish mission was a powerful datum in support of the demiurgical theologies that Justin sought to undercut. ${ }^{32}$ Therefore, contrary to Stylianopoulos's argument that Justin's preoccupation with conversion indicates that the Dialogue was written primarily for Jews, I suggest that the question of Jewish conversion was highly relevant to internal Christian debate as well. The issue should not be framed as a stark dichotomy (i.e., either Justin is writing for Christians or [indirectly] with an eye toward converting Jews). Instead, Justin's efforts to persuade Jews both within and outside of the text of the force of the proof-from-prophecy are directly relevant to his internal audience, in whose circles the status of the Jewish Scriptures was debated and the failure of Jews to convert was cited as an argument against the Scriptures' authority. I will argue in what follows that situating the Dialogue in the context of this intellectual contestation also accounts for the seemingly inconsistent literary strategies analyzed above.

\section{Explaining the Jews}

Justin recognized the reality that very few Jews were persuaded by the Christian message. ${ }^{33}$ However, he disagreed with his opponents about the reasons for this. Whereas they regarded the lack of Jewish conversions as evidence that the Jewish Scriptures did not refer to Jesus, Justin argued that there were other ways to account for this, and that the proof-from-prophecy was in fact persuasive, even to a Jewish audience. This argument could only be made by ending the Dialogue on the otherwise puzzling note that Trypho and his friends did not convert; the opposite scenario (i.e., conversion happens) would ignore the reality that few Jews accepted Jesus as Messiah and, consequently, would do nothing to undercut the forceful charges of Justin's demiurgical opponents on that basis. It is this concern 
with the implications of the failure of the Jewish mission, I suggest, that helps explain the ending of the Dialogue. Justin sought to convince his audience that while it is true that many Jews have not (yet) been persuaded by Christian claims (as is the case with Trypho at the end of the Dialogue), this is not due to any lack of force of the scriptural evidence (which Trypho finds largely persuasive), but to other factors.

The many remarkable concessions that Justin elicits from Trypho are meant, then, on my reading, to make the point that the proof-from-prophecy is convincing. In many of these instances, Trypho explicitly acknowledges the persuasive force of the scriptural evidence that Justin has quoted (as noted above). Indeed, Trypho and Justin agree that the only reason to listen to Justin's explanations at all is the fact that they are based on the Scriptures (Dial. 56.16 [Trypho], 68.1 [Justin]). The instances where Justin's claims are granted allow him to suggest that Jews are indeed compelled by arguments on the basis of biblical prophecy and that, to a significant degree, they do recognize that the Scriptures speak about Jesus. Their failure to ultimately convert, therefore, cannot be ascribed to any lack of force of the proof-from-prophecy.

This line of argument necessitated other explanations for their failure to accept Jesus as the promised Messiah. First and foremost, Justin claimed that this failure was due to their "hardheartedness." In doing so, Justin, perhaps intentionally, echoed the language of Paul, who had also spoken of "hardheartedness" in connection with Jewish refusal to regard Jesus as Messiah (Rom 9:18, cf. Acts 19:8-9). ${ }^{34}$ For Justin, it is because of this "hardheartedness" that the Jews did not draw the proper conclusions despite what he regards as the overwhelming force of the proof-from-prophecy. As he states in Dial. 53.2:

It had been explicitly prophesied that this would take place through the Christ, so when it did take place through him and it had become known, he made it manifest that he is the Christ. And yet, even after all these things took place and were proved on the basis of the Scriptures, you still remain hardhearted. ${ }^{35}$

Justin strongly emphasizes the persuasiveness of the proof-from-prophecy in this and other passages: everything has been described exactly as it happened, and so it is impossible to suggest that lack of clear reference to Jesus explains the Jews' failure to recognize him in the prophetic writings. Instead, their hardheartedness explains this failure, as Justin reiterates in Dial. 33.1: "this was said about our Jesus - the scriptural voices themselves indicate it - but your ears are fenced off and your hearts hardened." ${ }^{36}$ Justin makes the point again in Dial. 68.1: "When I am continually citing the Scriptures and offering such forceful explanations to support my view, I ask you to understand them. Yet you are hardhearted with respect to knowing the mind and will of God." ${ }^{37}$ At other points, Justin uses slightly different language, but the essential point is the same. The Jews, he argues, obstinately refuse to change their mind in the face of overwhelming evidence (Dial. 64.2, 
$67.2-4,108.1-3$, etc.). According to Justin, such stubbornness is but one of the Jews' many moral failings:

You have never manifested any friendship or love toward God or the prophets or toward one another. But, as was shown, you are found to have always been idolaters and murderers of the just, even to the extent that you laid hands on the Christ himself. And right up to the present day you remain in your evil way, cursing even those who prove to you that the one who was crucified by you is the Christ. Moreover, you claim that by being crucified he was shown to be an enemy of God and accursed (this is the result of your irrational thinking). Even though you have starting points, from the signs that occurred through Moses, to understand that this one is the Christ, you are unwilling.

$(\text { Dial. 93.4-5) })^{38}$

Passages like this with their harsh denunciatory tone are difficult to understand in terms of any real attempt to win over a Jewish audience. But they do make sense when read as part of Justin's effort to demonstrate why the Jews failed to recognize their own Christ despite clear proof: they are irrational (cf. Dial. 110.2), and they are "idolaters and murderers." If such people do not recognize Jesus as the Christ, this does not say anything about the persuasiveness of the proof-from-prophecy. Justin contends that their failure to accept Jesus as Messiah has resulted in their "cursing" those who "prove" this to them. This is the unsurprising denouement of the Jews' long history of disobedience and hatred of everything just and good, so Justin claims. His argument here ties in with his stress on the Jews' "hardheartedness" to explain why God instituted a temporary Law (see above, p. 55); their current dismissal of Jesus is part of a long tradition of disobedience, misunderstanding and disregard of God.

Justin's attempt simultaneously to suggest that the Jews were largely compelled by the proof-from-prophecy and to explain their failure to convert as due to stubbornness in the face of clear evidence results in the awkward juxtaposition noted above of Trypho's remarkable willingness to hear and accept Justin's arguments on the one hand, and harsh statements by Justin about Jewish unwillingness to truly listen, on the other. The shift from dialogue to pseudo-monologue after Dial. 90 may also be explained by the interpretative framework developed here. If Justin had let Trypho express agreement at every turn, his failure to convert at the end of the Dialogue would have made no sense at all, but the alternative (that Trypho would not agree with the force of Justin's scriptural proofs) was equally unfeasible. Hence the compromise that we find in the text, whereby there is simply no real response to Justin's scriptural arguments at all in the final section of the Dialogue.

Justin further develops his argument by claiming that the stubbornness and unfaithfulness of the Jews has been predicted and foreshadowed in Scripture. In doing so, he offers the same sort of argument that we encountered in Tertullian, 
who construed the Jews' rejection of Jesus as evidence of the validity of biblical prophecy. In Dial. 32.5, for instance, Justin writes:

\begin{abstract}
All of these things that I have said by way of digression, I said to you so that you would now finally be convinced of what God said against you, namely, "You are stupid children" (Jer 4:22), and, "Therefore, behold, I will proceed to remove this people, and I will place them elsewhere, and I will take away the wisdom of the wise, and the intelligence of the intelligent among them I will hide."
\end{abstract}

$(\text { Isa 29:14 })^{39}$

In this and similar passages (e.g., Dial. 20.4, 78.11, 119), Justin explains that the Jews' current misunderstanding is part of the divine plan (and conversely, so is the acceptance of Jesus by Gentiles [see, e.g., Dial. 52.4-53.1, 119-121]). Their failure to convert, then, confirms the reliability of the Scriptures. ${ }^{40}$

These are the main lines of Justin's argument to explain the failure of the Jews to convert. In his account, they recognize the compelling nature of the prooffrom-prophecy, but they are too stubborn and hardhearted to draw the appropriate conclusion, which in turn confirms the validity of biblical prophecy, since their disobedience had been foretold.

There are a few other elements in the Dialogue that can be read as additional explanations for the lack of Jewish converts: 1) Justin argues that the Jews are afraid of the Roman hostility that they will face upon becoming Christians; 2) he points to the influence of the Jewish teachers, who have kept ordinary Jews away from Christian truth; and 3) he implies that some Jews have rejected Jesus because they were confronted with heretical surrogates rather than "true" Christians. We will briefly look at each of these explanations in turn.

\title{
Cowardice in the face of Roman hostility
}

Justin suggests that some Jews did not convert out of fear for the prosecution (or

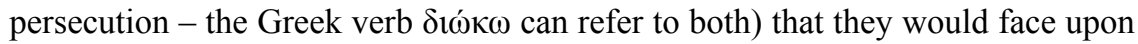
becoming Christians. He offers this suggestion as a supplementary explanation in addition to the Jews' purported hardheartedness in Dial. 44.1: "you are shown to be personally culpable if you refuse to accept the truth because you remain hardhearted or are weak of mind due to the death which is set apart for the Christians." ${ }^{41}$ The reference to "the death which is set apart for the Christians" echoes the more elaborate statement in Dial. 39.6, where Justin explicitly mentioned Roman hostility as an explanation for the Jewish failure to convert:

You probably also hesitate to confess that this one is the Christ ... to avoid being prosecuted by the officials, who, by the force of the evil and deceiving spirit (that is, the serpent), will not cease to kill and prosecute those who confess the name of the Christ. ${ }^{42}$ 
The scriptural evidence in support of Jesus's messiahship is clear enough, Justin argues, so the Jews' failure to convert must be due to other factors, such as fear of the repercussions that they may experience at the hands of Roman officials.

\section{The corrupting influence of the Jewish teachers}

Another way that Justin seeks to account for the lack of Jewish converts is by faulting the corrupting influence of Jewish teachers (e.g., Dial. 48.2, 68.8-9, 112.4-5, 134.2). Justin addresses the problem that so many Jews have failed to recognize Jesus as the Christ by suggesting that only very few of them have in fact considered the evidence on its own terms. Instead, they have been swayed by the deceitful interpretations advanced by their teachers. ${ }^{43}$ Justin advances this claim for the first time early on in the Dialogue: "you do not know what you are saying, but having been misled by teachers who do not understand the Scriptures and raving like an oracle, you say whatever enters your spirit" (Dial. 9.1). ${ }^{44}$ According to Dial. 38.1, these teachers went so far as to prohibit Jews from even speaking to Christians, an essentially uncorroborated claim that helps explain why so few Jews had come to believe in Jesus. ${ }^{45}$ They simply had not heard the Christian message, Justin suggests. As Trypho puts it in Dial. 56.16: "we have never before heard anyone who investigated, examined and demonstrated these things." ${ }^{\text {46 }}$

Not only have Jewish teachers made sure that the Christian message could not reach other Jews, they have also excised some scriptural passages that clearly refer to Jesus. In Dial. 71.1-2, for instance, Justin insists that "[Your teachers] have completely removed many scriptural passages ... on the basis of which it can be demonstrated clearly that this crucified one himself was announced as both God and man and as the one who would be crucified and would die" (cf., e.g., Dial. $72.1-4,73.1-6) .{ }^{47}$ No wonder that the Jews did not convert! Their teachers apparently kept all this remarkably persuasive evidence from them, or so Justin wants his audience to believe.

\section{The poisonous influence of the "heretics"}

Finally, Justin raises the possibility that Jewish rejection of the Christian message is related to the encounter with wayward Christians. In Dial. 82.3, in the context of discussing those who "taught atheistic, blasphemous and unjust things in his [i.e., Christ's] name," 48 Justin says to Trypho and his friends, "if you discover such men also among us, do not because of them blaspheme and exert yourself to misinterpret (the Scriptures). ${ }^{\circ 9}$ The possibility that an encounter with wayward Christians would lead Jews to be suspicious of Christian teaching in general may be further illustrated by Trypho's response to "heretical" ideas. In Dial. 35.1, Trypho says, "I know that many among those who say that they confess Jesus and are considered Christians eat meat sacrificed to idols and say that there is no harm in doing so. ${ }^{" 50}$ Eating such meat was anathema to most Jews, and their association of such practices with Christian teaching would certainly have contributed to the 
disrepute in which the Christian message was held. ${ }^{51}$ Similarly, in Dial. 80.4, Justin portrays his Christian rivals as those who "dare to blaspheme the God of Abraham and the God of Isaac and the God of Jacob and who even say that there is no resurrection of the dead." ${ }^{52}$ Again, the fact that Christians were saying such things that were deeply offensive to many Jews helps explain why they were not inclined to join the Christians. We will discuss these sections in more detail in the next chapter. At this point we simply note that these passages in the Dialogue help Justin explain the lack of Jewish conversion on grounds that do not support the demiurgical claim that Jews refused to convert because Jesus was not the one predicted in the Jewish Scriptures.

\section{Conspectus}

Thus far this chapter has sought to shed light on how Justin's anti-heretical efforts and his encounter with Trypho and the Jewish tradition are intertwined. It argued that the lack of Jewish converts constituted a problem for Justin not least because it was cited by his demiurgical rivals as evidence that the Jewish Scriptures were unrelated to Jesus. The Dialogue addresses this problem by explaining that many Jews failed to convert (a reality reflected in the text's ending) because of their hardheartedness, their fear of prosecution by the Romans, the misleading influence of their teachers, and the existence of "heretics" who presented the Jews with a counterfeit version of Christian teaching. According to Justin's presentation, it is for these reasons that so many Jews had not recognized Jesus as the Messiah, not because the Jewish Scriptures did not refer to him. In fact, when the scriptural evidence is presented to a Jewish audience, the Dialogue suggests, they find it compelling. This reconstruction helps explain many of the document's curious features, including its anticlimactic finale, Justin's harsh scolding of the Jews despite his stated aim of winning them over, and the remarkable number of moments where Trypho agrees with Justin.

In the following, final section of the chapter, I will argue that other literary aspects of the Dialogue can likewise be better understood when the document is situated in the context of internal Christian debate in the mid-second century. We turn first to the setting of the Dialogue shortly after the Bar Kochba revolt (132-135 CE) and will subsequently discuss the focus on philosophy in its introductory chapters.

\section{The shadow of Bar Kochba}

The form of Christianity that Justin opposed was characterized by an appealing straightforwardness: in the view of Marcion at least, Jews and Christians had no significant common ground. His was a vision of a Christianity devoid of any Jewish "baggage." It is easy to see how this construal would have been very appealing in the mid-second century. It not only solved theological problems regarding the differences between the "Old" and "New" Testaments, the apparent changes in 
God's character and demands, and so on. ${ }^{53}$ It also solved difficulties of a more pragmatic and political nature: it enabled early Christians in the period after the Bar Kochba revolt to construe their tradition as unrelated to that of the Jews. ${ }^{54}$ The failure of the second revolt meant the second defeat in a row for the Jewish God, and an even stronger opprobrium must have attached to the Jewish tradition after this debacle than after the first revolt. ${ }^{55}$ In this context, demiurgical versions of Christianity that avoided a close, positive connection to the Jewish God and the Jewish people must have been an attractive option. In A.H. 4.4.1, Irenaeus seeks to counter arguments of demiurgical opponents who claimed that the fate of Jerusalem demonstrated the impotence and inferiority of the Jewish God: "They venture to assert that, if it had been 'the city of the great King,' it would not have been deserted." The fate of the Jews and the defeat of Jerusalem were apparently cited as evidence by those who argued that the Jewish/Biblical God was not the superior being that Christians like Justin and Irenaeus claimed he was.

It is in this light, I propose, that we should understand the literary setting of the Dialogue shortly after the Bar Kochba revolt, which is a topic to which Justin returns with some frequency (Dial. 1.3, 9.3, 16.2-3, 92.2-3, 110.6, 139.3). This setting requires explanation not least because Justin published the Dialogue decades after his conversation with Trypho ostensibly took place. ${ }^{56}$ But if the failure of Bar Kochba and the appeal of demiurgical Christianity are connected, his choice to retroject the conversation to the immediate aftermath of this crucial moment becomes more easily explicable. Placing his narrative in this temporal setting allowed Justin to engage the "heretical" arguments about the failure of the Jewish God head on and afforded him the opportunity to explain why and how the fiasco of Bar Kochba did not imply any weakness on the part of the Jewish God. ${ }^{57}$

Justin argues that the present misfortune of the Jews is not due to the defeat of their God. Rather, it demonstrates God's foreknowledge and power. God punished them with the catastrophe of the revolt (Dial. 16.2-3, 19.2, 139.3) because they failed to understand the true sense of Scripture and because they were hostile to the Christians (Dial. 16.4-17.2). Since God knew that Jerusalem "would be taken from [the Jews]," he insisted that sacrifices only be brought there, so that he could make sacrifices cease by taking Jerusalem away from them (Dial. 40.2). Moreover, the Bar Kochba revolt and the alleged subsequent barring of the circumcised from Jerusalem show that there was a certain logic behind God's change in policy on circumcision (Dial. 92.2): God instituted circumcision to single out the Jews for punishment. By portraying the Bar Kochba revolt as part of the divine plan all along, then, Justin attempted to counter the impression that the failure of the revolt and the humiliating terms that followed afterward amounted to a defeat of the Jewish God, while also trying to solve the problem of apparent divine inconsistency with regard to sacrifice and circumcision. That the former (i.e., God's apparent defeat) is his main concern is suggested by the fact that the latter (i.e., God's apparent inconsistency) had already been explained by his appeal to the hardheartedness of the Jews. The post-Bar Kochba setting, in other words, was not required to make that particular point and is therefore probably better understood 
in terms of Justin's defense of God's potency. Situating the Dialogue shortly after the revolt foregrounded these issues and may hence be seen as informed by Justin's anti-demiurgical interests.

Justin's insistence that God has not been vanquished may also be reflected in his argument that Jerusalem will be rebuilt and restored in Dial. 80 (cf. Dial. 24.2-3, $25.2,5)$. This is in effect a claim that the destruction of the temple was not a defeat of the Jewish God, but that, to the contrary, the current miserable position of the Jews is part of the divine plan, a plan that includes his eventually turning matters around for the faithful.

The Bar Kochba revolt is often only mentioned in Justin scholarship in relation to Trypho's background, but clearly the failed Jewish revolt looms large in various sections of the Dialogue. This, then, is another example of how an important aspect of the Dialogue is further elucidated by taking intra-Christian debates into account. Justin's situating the Dialogue in the immediate aftermath of the Bar Kochba revolt facilitated a response to the "heretical" claim that this catastrophe was indicative of the inferiority of the Jewish God.

\section{The challenge of philosophy}

Finally, Justin's awareness of the challenges posed by his Christian rivals also helps explain more fully the opening chapters' focus on Greco-Roman philosophy. ${ }^{58}$ The first section of the Dialogue tells the story of how Justin and Trypho met: Trypho had taken up an interest in philosophy and approached Justin when he noticed that he donned the philosopher's cloak (Dial. 1.2). Prompted by Trypho's inquiries, Justin recounted his experience as a student of various philosophical schools, culminating in his time with the Platonists (Dial. 2.2-4). At some point, he met a certain "Old Man" who convinced him of the shortcomings of contemporary philosophy - chiefly the Platonism that Justin had most recently embraced - and introduced him to the biblical prophets and to Jesus, in whom their prophecies had been fulfilled (Dial. 3.1-7.3).

Scholars have debated the reasons for this extensive engagement with GrecoRoman philosophy at the outset of the Dialogue, since it seems largely unconnected to the rest of the conversation..$^{59}$ Justin and Trypho evidently shared the utmost respect for the biblical texts that form the basis for the remainder of the discussion, so why not start from there $?^{60}$ Crucial to understanding the purpose of this section, I suggest, is to recognize that it presents the reader with a choice. One must take as point of departure and frame of reference either the ancient Jewish law and prophets or contemporary philosophy. The need to choose between these two options is thematized already in the first question Justin asks Trypho after having learned his name and his "Hebrew" identity: "How can you benefit as much from philosophy as from your own lawgiver and the prophets?" (Dial. 1.3) ${ }^{61}$ As a result of his conversation with the Old Man, Justin himself had recognized that contemporary philosophy did not offer anything truly beneficial. Towards the end of their conversation, Justin therefore asked, "If the truth is not found with 
these people [the philosophers], whom else could one consult as a teacher, from where derive advantage?" (Dial. 7.1). ${ }^{62}$ The Old Man offered the biblical prophets as the alternative: "A long time ago, long before the time of all those so-called philosophers, there lived men who were blessed, just and loved by God ... they call them the prophets. They alone both knew the truth and declared it to the people" (ibid.). ${ }^{63}$ Justin frames the choice between these two alternatives as a stark binary: truth is found either with the philosophers or in the Jewish Scriptures. And while it is true that Justin regards philosophy as "truly the greatest possession," this applies only to philosophy in its original, undivided form (Dial. 2.1-2, see discussion on pp. 108-109). Contemporary philosophy, i.e. the Hellenistic philosophical schools, have nothing truthful to offer (Dial. 7.1). As the Old Man puts it in Dial. 5.1: "Those philosophers, then, know nothing about these matters." 64

Despite Justin's dichotomous approach to contemporary philosophy and biblical prophecy, and his clear disapprobation of the former, he pursues his argument in this section in a thoroughly philosophical manner. Indeed, the point of Justin's account of his engagement with various philosophical schools is to establish his credentials in dismissing them. Justin seeks to convey that he chose the prophets over the philosophers not because he was unaware of contemporary philosophical schools but precisely because he knew their systems well and found them wanting. The unsatisfactory nature of contemporary philosophy is brought out more fully in his conversation with the Old Man. Ironically very much in the manner of a latter-day Socrates, the Old Man identifies several difficulties in contemporary philosophy, especially Platonism. ${ }^{65} \mathrm{He}$ offers philosophical arguments to demonstrate the inadequacy of contemporary philosophy and defeats the philosophers on their own turf. His (and therefore Justin's) Christianity is not unaware of contemporary philosophy or unsophisticated in this regard. To the contrary, it is more sophisticated than anything contemporary philosophy has to offer. When Justin claims the mantle of "true philosophy" (Dial. 8.1-2), he clearly has in mind a philosophy that is based on the prophets, who are a surer source of wisdom than contemporary philosophy. ${ }^{66}$

It is not immediately obvious why Justin finds it necessary to formulate this opposition between prophecy and contemporary philosophy so sharply. It is difficult to see why it would be so problematic if Trypho remained interested in philosophy in addition to his commitment to the biblical texts. Why did Justin not follow the argumentative approach of 1 Apol., where he claimed a considerable degree of congruency between (contemporary) philosophy and prophecy, and by extension, Christianity? ${ }^{67}$ This might well have been an effective approach in his conversation with Trypho, especially since the latter had evidently already been impressed with contemporary philosophy (Dial. 1.2).

I propose that Justin's portrayal of the philosophical and the prophetic as mutually exclusive in the Dialogue can be explained in light of the fact that the views of many of Justin's Christian rivals resonated with Greco-Roman philosophical currents, chiefly Platonism, while standing in various degrees of tension with the Jewish scriptures. ${ }^{68}$ Questions as to whether Justin's demiurgical opponents were 
directly inspired by contemporary philosophy and whether they were primarily philosophers or biblicists are of limited relevance in this connection. What matters most is that their demiurgical theories resonated with contemporary philosophical notions. The opening chapters of the Dialogue, then, can be read as a defense of a form of Christianity that seeks to base itself on the Jewish Scriptures while casting aspersions on "Christianities" that could claim resonance with contemporary philosophical ideas, but not with said scriptures. ${ }^{69}$

Justin's first objection to philosophy is certainly immediately relevant to his conflict with demiurgical Christians. He tells Trypho, "the majority of the philosophers have not carefully considered this, whether there is one or even multiple gods" (Dial. 1.4).$^{70}$ Justin's claim implies that while his opponents' ideas may dovetail with philosophical notions about the Demiurge (or multiple demiurging figures), this does not render them compelling, because the philosophers themselves have not considered this question carefully.

The same sort of implicit criticism of demiurgical notions may be seen in what follows, when Justin criticizes the notion of a Supreme God far removed from the lives of individual human beings (Dial. 1.4). ${ }^{71}$ In his view, this idea has disastrous moral implications: "for those who hold these opinions, the result is immunity and license to speak, i.e., to do and say whatever they want, without either fear of punishment or hope for some kind of good from God" (Dial. 1.5). ${ }^{72}$ By criticizing the philosophers on this point, Justin is simultaneously criticizing Christian demiurgists who similarly posited a Supreme God standing at considerable remove from creation. Justin's statement about the ethical implications of such notions implies a critique of the moral character of his Christian rivals as well.

It cannot be coincidental that much of what follows in the discussion centers on Plato (Dial. 3.7, 4.1, 5.1, 8.3). ${ }^{73}$ The Old Man first takes up the question of whether philosophy (i.e., Platonism) offers a sound epistemology to attain knowledge of God (Dial. 3.4-3.7), which then leads to a discussion of the nature of the soul (Dial.4.1-5.1) and the cosmogenic ideas advanced in the Timaeus (Dial.5.1-6.2). It was Plato, and this Platonic dialogue in particular, that more than anything else gave intellectual respectability to the notion of a Demiurge, and by extension, Christian demiurgical theologies. ${ }^{74}$ The significance of Plato's support is roundly rejected by the Old Man, however. When Justin asks: "(Do you think that) Plato and Pythagoras, the wise men who became, so to speak, a wall and bulwark of our philosophy, were unaware of these things?" (Dial. 5.6) ${ }^{75}$ the Old Man responds, "I do not care ... if Plato or Pythagoras or anyone else entertained such opinions" (Dial. 6.1). ${ }^{76}$ This is the view that Justin seeks to inculcate in his audience: congruence with philosophical notions is ultimately of no concern.

We need not assume that Justin was uninterested in engaging contemporary philosophical ideas in order to recognize that his comments here touched upon his debate with Christian demiurgists. Stated differently, it is unlikely that when Justin criticized philosophy in general and Plato in particular (most notably, his Timaeus) he would have been unaware of the fact that some of his Christian rivals could cite in support of their position its compatibility with contemporary 
philosophical (especially Platonist) notions, and that his critique would therefore serve to undermine their intellectual claims.

\section{Conclusion}

There is much about the literary form of the Dialogue that invites investigation. The text presents a discussion between a Christian and Jew(s) that surprisingly ends without any conversions, and that features many harsh comments about the Jews that stand at odds with Justin's evident evangelistic motives. In addition, it contains a surprising number of instances in which Trypho and his friends are convinced by the scriptural evidence marshaled by Justin. Moreover, the conversation is set against the backdrop of the Bar Kochba revolt even though it was published decades later, and it opens with a section focusing on Greco-Roman philosophy that has only limited connection with what follows. Each of these features of the text, many of which in the past have proven difficult to explain, are intelligible in terms of Justin's response to the questions and objections posed by his demiurgical Christian rivals. Without reducing Justin's aims and motivations to this single interest, this chapter has demonstrated that situating the Dialogue in the context of the debate between demiurgical and non-demiurgical Christians more fully and substantially elucidates these authorial decisions.

For example, the function of the literary setting of the Dialogue shortly after the Bar Kochba revolt and the many references to that historical event become more fully comprehensible upon recognition that this disastrous event was interpreted as yet another defeat of the Jewish God, which offered a significant impetus to, or confirmation of, theologies that regarded the Jewish God as an inferior divinity. Justin's preoccupation with such theologies also helps explain the opening section that focuses on Greco-Roman philosophy and at first glance seems tenuously related to the rest of the Dialogue. By criticizing contemporary philosophy in general and Platonism in particular (especially Plato's Timaeus), Justin challenged the appeal of the theories of his demiurgical rivals, whose congruence with Platonic demiurgy provided a degree of intellectual respectability to their views.

Other literary features likewise become intelligible when we take Justin's interest in combatting "other" Christians into account. We noted that Tertullian confirms what we would at any rate logically expect, namely that demiurgical Christians cited the Jewish failure to recognize Jesus as the Messiah promised in their Scriptures in support of the view that Jesus was unrelated to the God of the Old Testament and his prophets. Situating the Dialogue within this context helps explain Justin's rhetorical decisions. He acknowledges that most Jews did not convert. This is clear, inter alia, from his emphasis on a "remnant" that will be saved. But he argues that this has nothing to do with the force of the prooffrom-prophecy. To the contrary, according to Justin's presentation, the scriptural evidence is actually largely compelling to his Jewish interlocutors. The persuasive power of scriptural prophecy is evinced by the many instances where Trypho and his companions assent to Justin's interpretations. 
Having acquitted the scriptural evidence of suspicion, Justin offers alternative reasons for why so few Jews had accepted the Christian message. His primary strategy was to insist on Jewish stubbornness ("hardheartedness") in the face of overwhelming evidence; many Jews, he claimed, simply refuse or are unable to accept the truth. This explains Justin's harsh utterances against the Jews, who are depicted as unwilling and incapable of discerning God's plan. Justin construes this hardheartedness as the fulfillment of biblical prophecy, thereby in effect turning his opponents' argument on its head: the Jewish failure to convert is presented as confirmation of the truth of the Jewish Scriptures. Justin further explained the lack of Jewish conversions by maintaining that the Jews were afraid of Roman prosecution; by stressing the corrupting influence of the Jewish teachers who denied other Jews access to the Christian message; and by implying that Jews rejected "Christianity" because of its false representation by the "heretics."

In light of these rhetorical strategies, the ending of the Dialogue is not all that surprising. Since Justin sought to explain why most Jews did not respond favorably to the Christian message, it would have made little sense for the Dialogue to end with the conversion of Trypho and his friends. Had the Dialogue ended with conversion, it would have failed to counter the forceful argument of Justin's opponents. Justin's emphasis on the obduracy of the Jews, in combination with his insistence that they did not convert out of fear of prosecution, has prepared the reader for the lack of conversion at the end of the document. At the same time, now that Justin has presented the scriptural evidence in support of his form of Christianity (unencumbered by the interference of the Jewish teachers and Christian "heretics"), much of which Trypho and his companions considered compelling, it makes sense that they do not flat-out reject Justin's message, but instead express interest in continuing the conversation. This should be read as a testimony to the force of the proofs-from-prophecy that Justin has supplied. In spite of the obstinacy that Justin regards as characteristic of the Jews, his scripture-based evidence has been so persuasive that Trypho retains his interest, and thus the hope that he will one day join the "remnant" that will be saved remains alive. This in turn communicated to Justin's Christian readers that evangelizing the Jews was not necessarily a lost cause and offered motivation to engage in the sort of conversation that the Dialogue exemplifies.

Reading the Dialogue in this way avoids the problematic conclusion that because the text is addressing certain internal Christian concerns, the engagement with Jews and Judaism is only a pretext or a charade. I find unpersuasive the hypothesis that Justin was writing with an eye on internal Christian issues only and had no interest whatsoever in persuading Jews. As Stylianopoulos has pointed out, Justin likely did want to convince as many Jews as possible of his point of view. ${ }^{77}$ Justin presumably hoped that the arguments developed in the Dialogue would ultimately make their way to a Jewish audience and that the engagement between Jews and Christians that the text describes would be replicated in Jewish-Christian encounters. However, this aim is by no means unrelated to internal Christian debates about the Jewish heritage of "Christianity." The desire 
to convince Jews that their Scriptures speak of Jesus is partly informed by internal Christian debates about the status of the Jewish Scriptures. If more Jews could be persuaded of Justin's Christian views, this would help counter the demiurgical view that the Jewish Scriptures were unrelated to Jesus. It is unhelpful therefore to frame the issue as a dichotomy - either Justin seeks to persuade an outside ("Jewish") audience or he is addressing internal ("Christian") concerns. For Justin the two aims were clearly connected. ${ }^{78}$

In sum, this chapter has argued that in addition to passages that engage the arguments put forward by Christian demiurgists (analyzed in Chapter 3), there are a substantial number of literary aspects of the Dialogue that can be better explained if we situate the document against the background of internal Christian contestation. Justin's opponents could cite in support of their views the lack of Jewish conversion (intimating that Jesus was not the one foretold in the Jewish Scriptures), the defeat of the Jewish God in recent revolts (suggesting that he was not the Supreme God), and the relative compatibility of their demiurgical theologies with the widely revered Greek philosophical tradition (since Platonic speculation about demiurgy lent them an aura of intellectual respectability). Much in the Dialogue can be explained in terms of Justin's efforts to respond to these claims and in doing so defend his own version of Christianity.

\section{Notes}

1 Cf., e.g., the endings of the Dialogue of Athanasius and Zacchaeus, the Dialogue of Timothy and Aquila and the Dialogue of Simon and Theophilus. See Harold Remus, "Justin Martyr's Argument with Judaism," in Separation and Polemic, ed. Stephen Wilson (Waterloo, ON: Wilfrid Laurier University Press, 1986), 75 n. 63, for bibliographical details and discussion. Cf. also, e.g., Lucian's Hermotimus and Minucius Felix's Octavius, which likewise feature a clear resolution. Other literary dialogues do not have a clear winner at the end, but as Timothy Horner, who provides a helpful overview of such dialogues, notes: "even if the ending of the Dialogue is similar to other second-century documents, this does not mean that Justin used this ending simply because other people were doing it. The ending had to fit into his own apologetic agenda" (Horner, Listening to Trypho, 99).

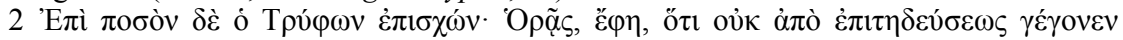

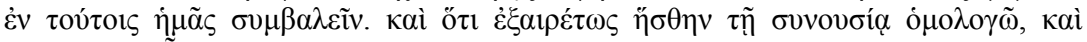

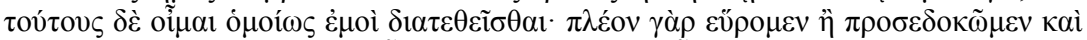

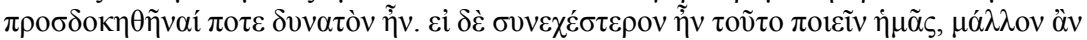

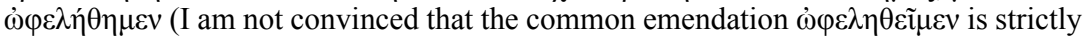

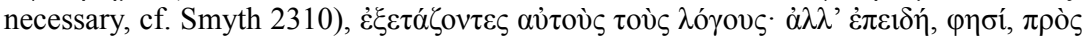
$\tau \tilde{\eta} \dot{\alpha} v \alpha \gamma \omega \gamma \tilde{\eta}$ (sic; iota subscript is missing in Goodspeed and Marcovich; Bobichon

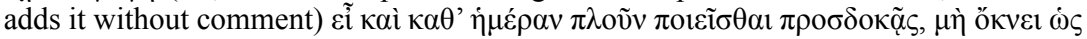

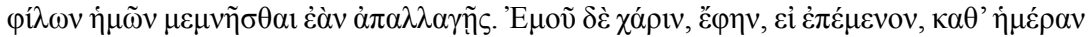

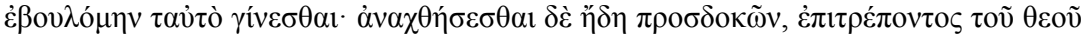

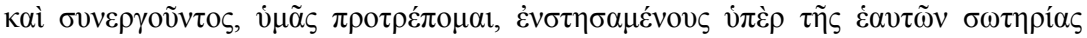

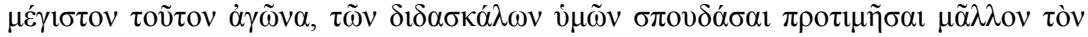

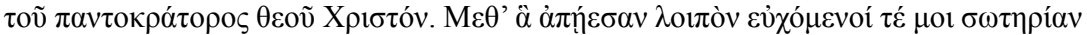

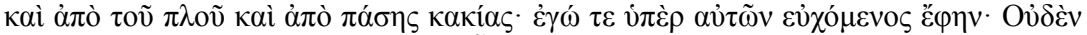

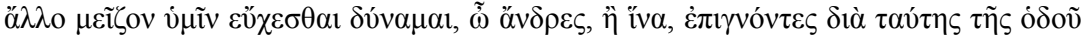




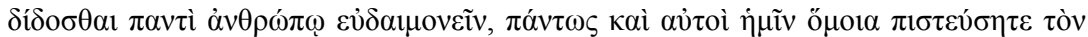

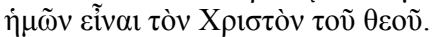

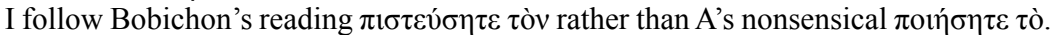
This relatively minor emandation is preferable to Marcovich's more complicated sug-

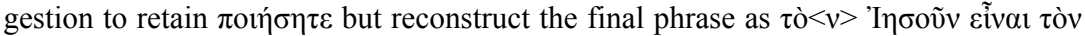

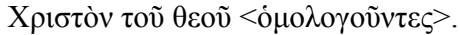

3 Ben Zion Bokser, "Justin Martyr and the Jews," JQR 64 (1973): 98; Horner, Listening to Trypho, 103-7.

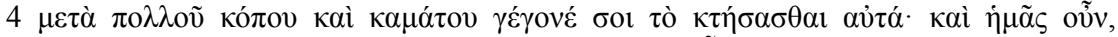

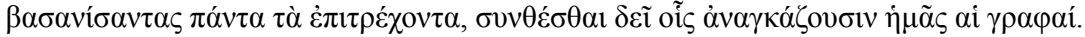

5 All of these passages cannot be dismissed simply as mere "hints to missionary intentions" that are "nothing but marginal notes" (so Michael Mach, "Justin Martyr's Dialogus cum Tryphone Iudaeo and the Development of Christian Anti-Judaism," in Contra Iudaeos: Ancient and Medieval Polemics between Christians and Jews, ed. Ora Limor and Guy G. Stroumsa [Tübingen: Mohr Siebeck, 1996], 36).

6 Cf. Stanton, "God-Fearers," 360: "Why did Justin write his Dialogue? I do not think that his main aim was to 'win over' Jews such as Trypho. If that had been his hope and expectation, he would not have allowed Trypho to go his own way at the conclusion of their vigorous discussions spread over two days"; Wilson, Related Strangers, 264: "Trypho and his friends are not persuaded - surely an odd way to end an argument designed to convert Jews."

7 Horner, Listening to Trypho, 95-6, notes how this ending has baffled many readers and discusses the lack of convincing explanations offered in the scholarly literature.

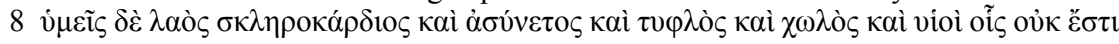

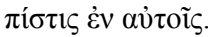

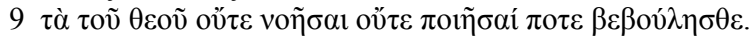

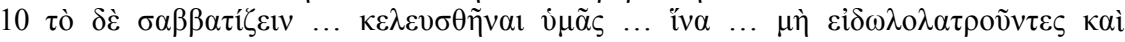

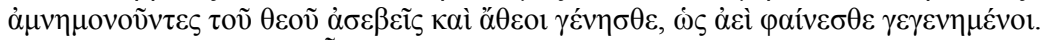

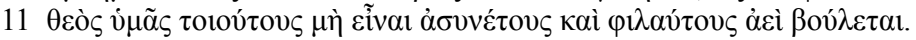

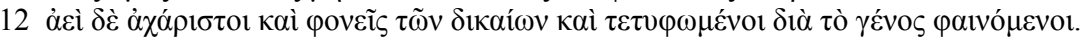

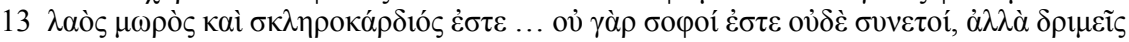

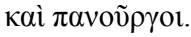

14 Rajak, "Apologetic," 68, collects a number of examples. She rightly notes that while it is true that Justin is less extreme in his denunciation of the Jews than some later Christian authors, this does not render the Dialogue's conversation friendly or goodhearted.

15 Cf., e.g., Dial. 64.2-3, 67.3-4, 78.10, 115.5-6, where Trypho is clearly among the addressees of Justin's insults. Pace, e.g., Horner, Listening to Trypho, 104.

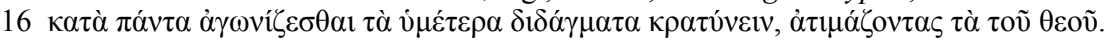

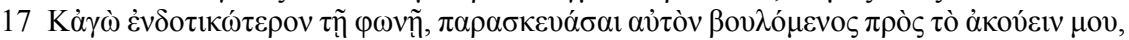

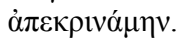

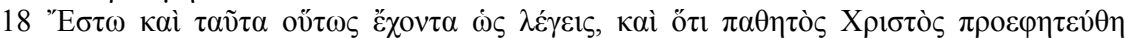

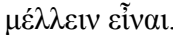

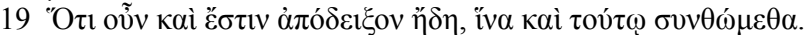

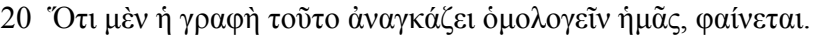

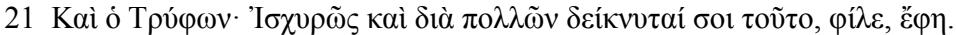

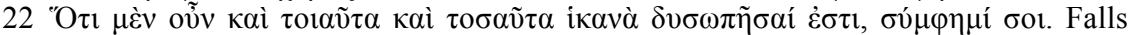
translates $\delta v \sigma \omega \pi \tilde{\eta} \sigma \alpha 1$ "to make me confused," but this is a rather unusual rendering of $\delta v \sigma \omega \pi \varepsilon \dot{\varepsilon} \omega$. With Geoffrey W.H. Lampe, A Patristic Greek Lexicon (Oxford: Clarendon Press, 1961), 394, I take it in the sense of "to convince, persuade." Cf. Dial. $46.5,68.7$.

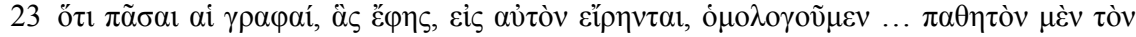

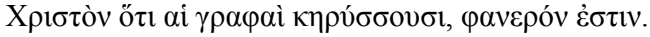


24 Cf. Wilson, Related Strangers, 260: "if Trypho makes concessions, he does so on minor issues that do not affect his fundamental opposition to the Christian line, and he usually couples them with requests for further evidence, new questions, or a more general statement of opposition" (emphasis added). Wilson refers to Demetrios Trakatellis, "Justin Martyr's Trypho," HTR 79 (1986): 287-97 who likewise downplays the significance of Trypho's many concessions. Cf. also Remus, "Justin Martyr's Argument with Judaism," 67; Horner, Listening to Trypho, 109. Skarsaune, The Proof from Prophecy, 210, is virtually alone in appreciating the oddity of Trypho's concession that there are two gods: "Trypho declares himself ... fully convinced by Justin's argument. This is of course quite unrealistic. In the entire Dialogue there is hardly any argument more offensive to a Jew than the argument concerning the Second God in Dial. 56-60."

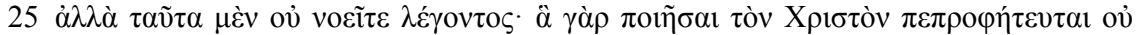

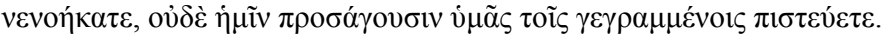

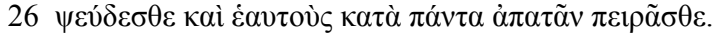

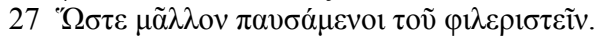

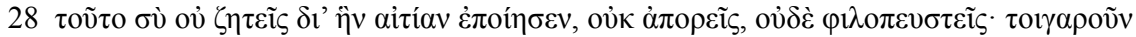

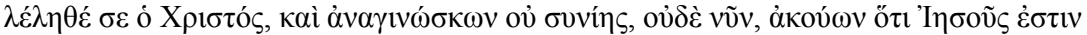

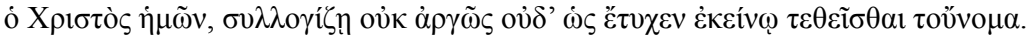

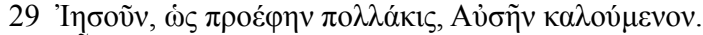

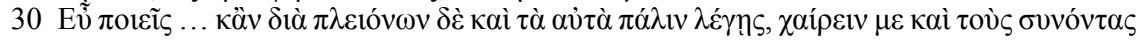

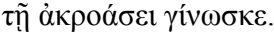

31 Even Rodney Stark, who argues against the scholarly consensus that the Jewish mission was a failure, maintains that probably fewer than one out of five Jews converted to Christianity (Rodney Stark, The Rise of Christianity: A Sociologist Reconsiders History [Princeton, NJ: Princeton University Press, 1996], 70). Justin's own "remnant" language (see n. 40) indicates that few Jews had converted. Also relevant in this connection are Justin's multiple references to the Christians as "we gentiles," which suggests the group had a predominantly, or even exclusively, gentile character. For discussion of this expression and its significance, see Terence L. Donaldson, “'We Gentiles': Ethnicity and Identity in Justin Martyr," EC 4 (2013): 216-41. Cf. also Wilson, Related Strangers, 274: "[Justin] sometimes gives the impression that he saw Gentiles as the natural, even the sole, inheritors of God's promises, even though he knew that Jewish Christian groups existed." Similarly, Lieu, Image and Reality, 136-7.

32 Whatever one makes of Tertullian's explanation, it is clear that the failure of the Jews to recognize Jesus presented the demiurgists with a powerful argument. Indeed, the argument is compelling enough to render it unlikely that Tertullian made it up himself (he is not, at this point, setting up a straw man that can be easily knocked down).

33 At one point, Justin insists that some Jews do convert on a daily basis (Dial. 39.2), but his appeal in the immediate context to the "seven thousand men" who did not bow to Baal in the time of Elijah intimates that such converts represented but a small minority of Jews. Cf. also n. 31 and 40.

34 Cf. also غ̇ $\pi \omega \rho \omega ́ \theta \eta \sigma \alpha v$ in Rom 11:7 and $\pi \omega ́ \rho \omega \sigma เ \varsigma$ in 11:25.

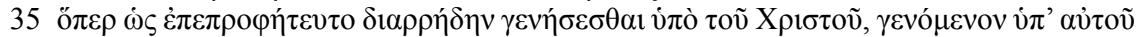

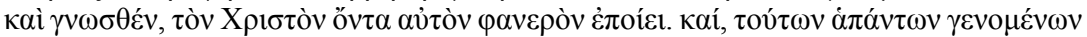

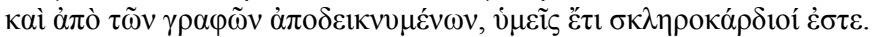

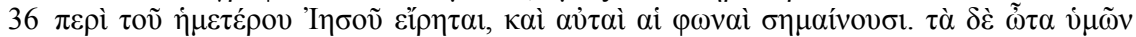

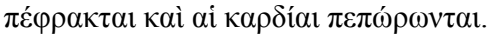

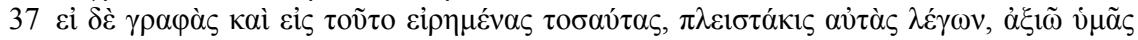

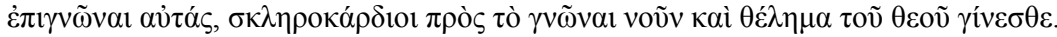

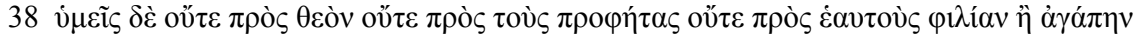

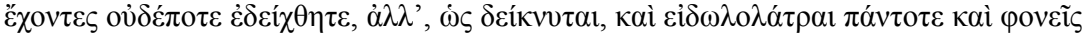

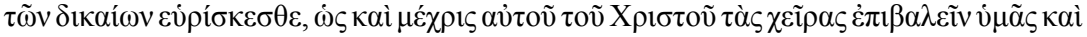




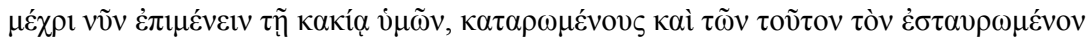

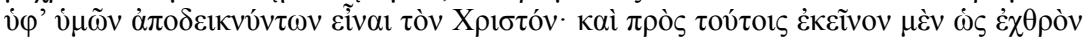

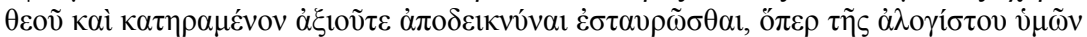

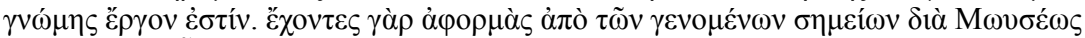

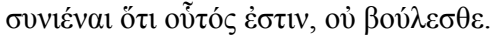

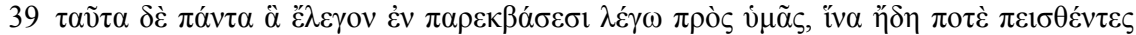

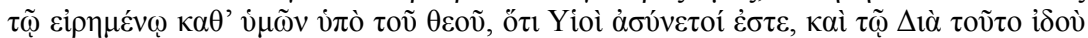

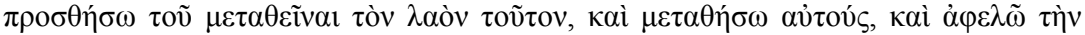

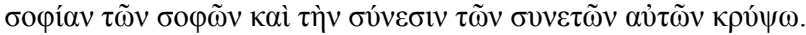

40 This raises the question of why Justin tries to persuade the Jews at all if it is part of the divine plan that the great majority of them reject Jesus. Justin, however, stresses that a remnant will be saved (Dial. 25.1, 32.2, 55.3, 64.2-3; for discussion, see Stylianopoulos, Justin Martyr and the Mosaic Law, 39-42) and that he has a divine commission to speak regardless of the results (e.g., Dial. 38.2, 44.1, 68.1, 82.3, 125.1-2, cf. Horner, Listening to Trypho, 101-2).

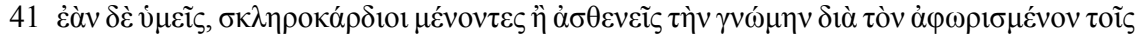

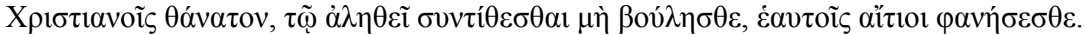

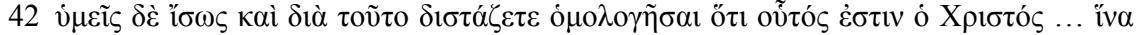

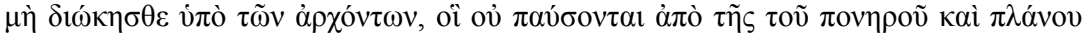

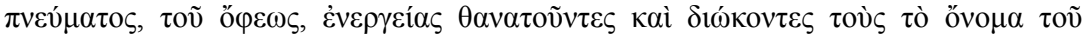

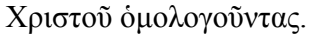

43 The argument developed here should caution against taking the references to the Jewish teachers as straightforward social description. Cf., e.g., Osborn, Justin Martyr, 13: "The Jews were still greatly dependent on their teachers."

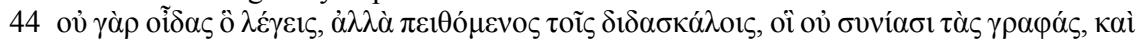

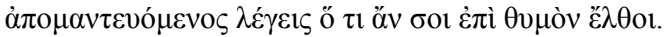

45 Even though t.Hullin 2.20-22 records, approximately a century after Justin, a prohibition of some forms of interaction with minim, this passage does not forbid all communication per se, and the minim in view are almost certainly Jews, not gentiles. Again, its function as part of Justin's argument should caution against taking this claim as a simple historical datum (cf. n. 43 above). See also Claudia J. Setzer, Jewish Responses to Early Christians: History and Polemics, 30-150 C.E. (Minneapolis: Fortress Press, 1994), 145 .

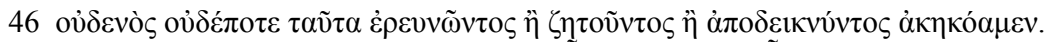

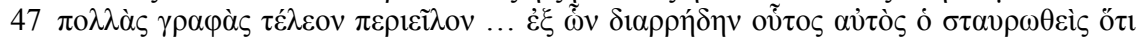

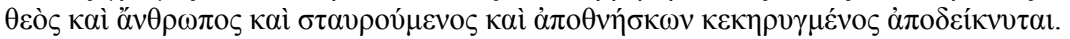

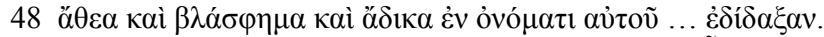

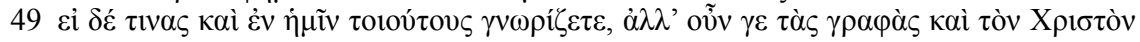

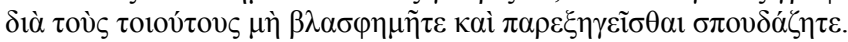

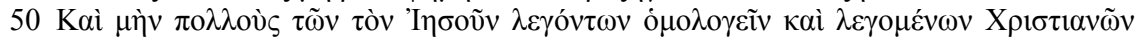

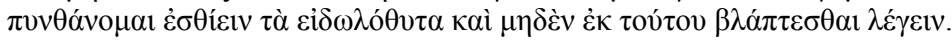

51 See, e.g., 4 Macc 5:2, m. 'Abod. Zar. 2:3; cf. Acts 15:20-29.

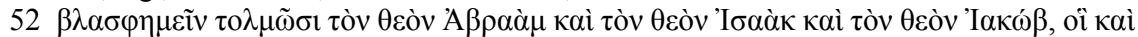

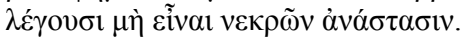

53 Marcion's stress on the new is a much easier and straightforward position than Justin's new-and-yet-old, Jewish-and-yet-not. Lieu, Marcion and the Making of a Heretic, 75 offers insightful remarks.

54 Cf. 1 Apol. 31, where Justin seeks to claim continuity with the old Jewish scriptures, while distancing himself from contemporary (post-)Bar Kochba Judaism.

55 Or the third if one counts the failed uprisings of 115-117 CE in Cyprus, Cyrenaica and Egypt. Like the first revolt, the Bar Kochba revolt must have been widely known throughout the Roman world, because of the extraordinary measures taken by the 
Romans to subdue the revolt as well as the extensive destruction left in its wake. See, e.g., Hanan Eshel, "The Bar Kochba Revolt, 132-135," in The Cambridge History of Judaism, Volume 4: The Late Roman-Rabbinic Period, ed. Steven T. Katz (Cambridge, UK; New York: Cambridge University Press, 2006), 123-5.

Martin Goodman sums up negative comments about the Jews in Quintilian, Tacitus, Florus and Diogenes, and notes: "Whether such hostile attitudes became standard in the city of Rome or elsewhere in the empire after 135 cannot now be determined, but they are unlikely to have evaporated quickly" (Rome and Jerusalem: The Clash of Ancient Civilizations [New York: Alfred A. Knopf, 2007], 494-5). He regards as a main reason for the growth of Christianity "that after 70, and even more after 135, Christians presented themselves to the gentile world as unconnected to the Jews, whose alienation from mainstream Roman society had been sealed ..." (512); it was imperative for Christians to distance themselves from the Jews because in the Roman World "the name of the Jews evoked hostility and fear after the devastation caused by the rebels of 66-70, $115-17$ and 132-5" (530).

It is sometimes maintained that Judaism was gaining many new adherents in this period, which would undermine the hypothesis that after the Bar Kochba revolt the Jewish tradition lost some of his appeal. However, the data on which the notion of rapid demographic increase is based are unreliable. See Fredriksen, "What Parting of the Ways?," 49-50. Note also Seth Schwartz's argument that many Jews in Syria Palaestina abandoned their ancestral traditions (in Seth Schwartz, Imperialism and Jewish Society 200 B.C.E. to 640 C.E. [Princeton: Princeton University Press, 2001]), which is hardly compatible with the notion that Judaism was particularly attractive to outsiders around this time. Contrast, e.g., Rudolph, Denn wir sind jenes Volk, 45, who claims without convincing proof that after the defeat of Bar Kochba "verstärkten sich die jüdischen Missionsbemühungen und damit der Wettbewerb mit den Christen um die gleichen potentiellen Konvertiten. Gerade im Rom Justins waren die jüdischen Erfolge enorm."

56 On the date of the Dialogue, see p. 1.

57 Various scholars have posited the Bar Kochba revolt as the background to criticism of the Jewish God prevalent at this time. See, e.g., Robert M. Grant, Gnosticism and Early Christianity (New York: Columbia University Press, 1959), 27-38; Wilson, Related Strangers, 218. Judith Lieu urges caution, arguing that "it is difficult to see how this could be proven, or whether it explains much else that is characteristic of these [Gnostic] writings" (Lieu, Marcion and the Making of a Heretic, 317). I grant that it is difficult to prove the impetus behind demiurgical notions, but would still like to point out that such theologies must have seemed more compelling after the Bar Kochba revolt (even if they were not initially inspired by it). On a related note, in Justin's case it is clear that the Bar Kochba revolt is on his mind; this is not a mere supposition as in the case of the great majority of contemporary writings.

58 For other readings that similarly uncover an anti-heretical aim in these opening chapters, see Robert M. Royalty, "Justin's Conversion and the Rhetoric of Heresy," in Studia Patristica, Vol. XL, ed. Frances M. Young, Mark J. Edwards, and Paul M. Parvis (Leuven: Peeters, 2006), 509-14; Hayes, Justin against Marcion, 92-141.

59 Cf., e.g., Hyldahl, Philosophie und Christentum, 21-2.

60 One common solution to this difficulty is to argue that Justin is addressing a "pagan" audience at this point. Cf., e.g., Oskar Skarsaune, "The Conversion of Justin Martyr," Studia Theologica 30 (1976): 59: “Justin's argument is not addressed to Trypho, the Jew, but to the gentile readers of the Dialogue. Trypho had no need to be convinced of the superiority of the prophetic books, but the pagan readers of the Dialogue had." This thesis is problematic insofar as it rests on the hypothesis of a pagan audience, which we have argued in Chapter 2 is unpersuasive. It should be noted, moreover, that the forceful rejection of contemporary philosophy in this section of the Dialogue is not paralleled 
in the Apologies, where Justin actually addresses the concerns of a more general GrecoRoman audience. In that context, he pursues a greater synthesis between philosophy and Christianity than he does here. The strong polemic against contemporary philosophy in the Dialogue makes better sense in relation to internal Christian debates, as the present section will demonstrate.

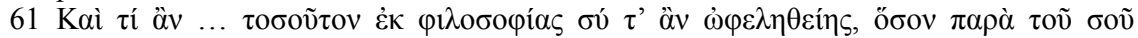

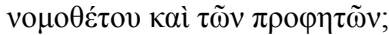

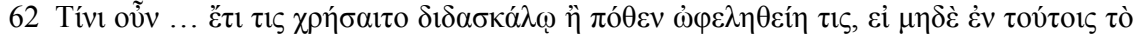
$\dot{\alpha} \lambda \eta \theta \dot{\varepsilon} \varsigma \dot{\varepsilon} \sigma \tau \imath v$

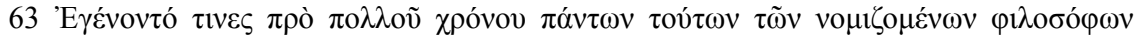

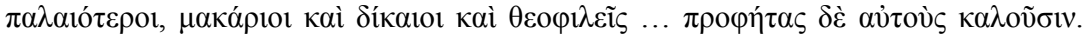

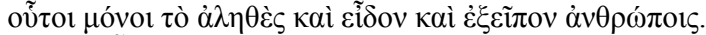

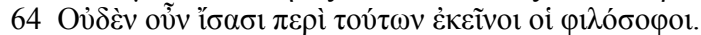

65 On the Socratic qualities of the Old Man, see Skarsaune, "The Conversion of Justin Martyr"; Edwards, "On the Platonic Schooling of Justin Martyr."

66 This of course is how Justin's rhetoric presents it; his own Christian views were evidently deeply indebted to contemporary philosophical notions as well.

67 Cf., e.g., 1 Apol. 44.8-10, 59-60, 2 Apol. 13.2.

68 Platonism deeply influenced Christian demiurgists of various stripes. See, e.g., Markschies, Valentinus Gnosticus?, 324-30; Löhr, Basilides und seine Schule; John D. Turner, Sethian Gnosticism and the Platonic Tradition (Sainte-Foy, Quebec: Presses de 1'Université Laval, 2001); Stephen Emmel, "The Gnostic Tradition in Relation to Greek Philosophy," in The Nag Hammadi Texts in the History of Religions, ed. Søren Giversen, Tage Petersen, and Jørgen Podemann Sørensen (Copenhagen: Kongelige Danske Videnskabernes Selskab, 2002), 125-36.

69 For Justin, part of what makes the prophets reliable sources is that they "glorified God, the Father and Maker of all things and proclaimed Christ, his son, who came from him" (Dial. 7.3) in contrast to certain false prophets, who are active even now. This passage, which has been discussed above (pp. 60-61), offers additional evidence that Justin's Christian rivals were on his mind in this section. A further reflection of this preoccupation with misguided "Christians" may be seen a few lines down in Dial. 8.2 where Justin states, "I wish that everyone would make an effort similar to my own to not fall away ( $\dot{\alpha} \varphi$ í $\tau \alpha \sigma \theta \alpha \imath$ ) from the words of the Savior; for they have a certain fear-inducing quality in them that is capable of convincing those who have

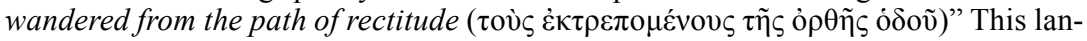
guage more fittingly refers to those who once believed in the correct manner rather than to people who never believed in Jesus at all. Cf. Skarsaune, "The Conversion of Justin Martyr," 60-1.

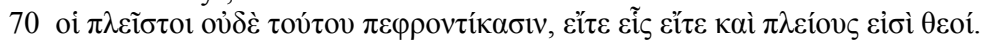

71 See Jacobus C.M. van Winden, An Early Christian Philosopher: Justin Martyr's Dialogue with Trypho, Chapters One to Nine, Philosophia patrum 1 (Leiden: Brill, 1971), 36-8, who argues that although the Aristotelean conception of God is the one that most obviously fits Justin's critique, Justin could "have had the Platonists in mind, since they do not allow the first God - to Justin the only God - to be concerned with individuals" (38).

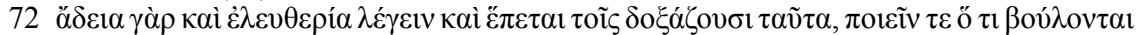

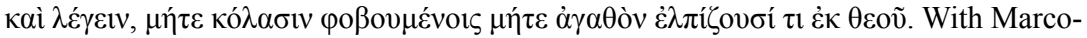
vich et al., I read ह̌ $\pi \varepsilon \tau \alpha 1$ for A's $\varepsilon \check{\pi} \varepsilon \sigma \theta \alpha 1$. Van Winden, An Early Christian Philosopher, 40-1, offers a helpful discussion of the text critical problems in this passage.

73 Ibid., 58 et passim. See also Bobichon, Justin Martyr, Dialogue avec Tryphon, 2: 586-90; Lampe, From Paul to Valentinus, 418-22; Edwards, "On the Platonic Schooling of Justin Martyr." 
74 On the influence of the Timaeus in shaping various theories of demiurgy in the first-third centuries CE, see Carl Séan O'Brien, The Demiurge in Ancient Thought: Secondary Gods and Divine Mediators (Cambridge: Cambridge University Press, 2015).

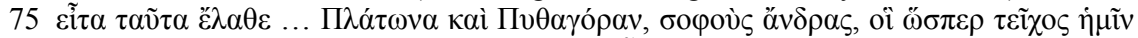

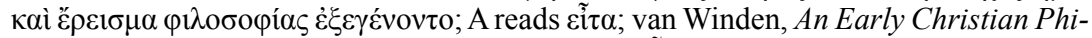

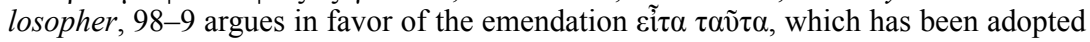
here. For various other proposals, see Bobichon, Justin Martyr, Dialogue avec Tryphon, 1: 202 .

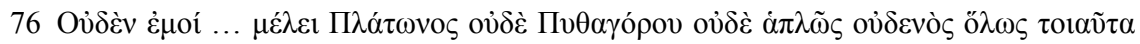

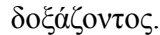

77 See above, p. 41.

78 In the same vein, I do not wish to argue that Justin's focus on "heretical" Christians is necessarily the only reason why he made certain authorial choices, but rather that this was one very significant factor that must be recognized in order to fully appreciate his literary decisions. 


\section{IN FAVOR OF HERESIOLOGY}

The clearest evidence that Justin was deeply concerned with heresy in the Dialogue is found in a number of passages in which Justin directly refers to "heretical" Christians. In Dial. 35.4, for instance, he claims that there are "many men who, although coming in the name of Jesus, teach (others) to speak and act in accordance with what is atheistic and blasphemous." Such people, he says elsewhere, "dare to blaspheme the God of Abraham and the God of Isaac and the God of Jacob" (Dial. 80.4). ${ }^{2}$

These and related passages have received considerable scholarly attention in the wake of Alain Le Boulluec's identification of Justin as the "inventor of heresy." 3 Part of what made Justin such an important figure for Le Boulluec is that he detected in Justin's work a shift in usage of the Greek word hairesis. Whereas it originally had a neutral sense and denoted "choice," "philosophical or medical school" (etc.), Justin and later early Christian authors began to consistently use it with reference to those whose teachings they thought rendered them nonChristians, despite these believers' own claim to the contrary. ${ }^{4}$

The Dialogue assumes particular importance in this connection, because the great majority of occurrences of the lexeme hairesis in Justin's corpus appear in this text. ${ }^{5}$ Scholars have sometimes discussed these passages with limited concern for the broader literary and rhetorical context in which they appear. The sections in question have routinely been treated as "interludes" or "digressions" essentially unrelated to the Dialogue's main argument about the relationship between "Judaism" and "Christianity." In light of the argument developed in this study, I suggest that these passages are better understood as moments that render explicit the antidemiurgical force of the Dialogue as a whole, especially since "demiurgism" is clearly central to what Justin describes as "heresy" in the Dialogue. He mentions by name the Marcionites, ${ }^{7}$ Valentinians, Basilidians and Saturnilians ${ }^{8}$ and summarizes the common denominator among the "heretics" as follows (Dial. 35.5):

They teach people to blaspheme the Creator of All (as well as the Christ, whose coming was foretold by him), i.e. the God of Abraham and Isaac and Jacob. We have nothing to do with them, because we know that they 
are atheistic, impious, unrighteous and unlawful and instead of worshiping Jesus only confess him by name. ${ }^{9}$

Justin does not use the word "Demiurge" here, as he did in 1 Apol., but he is clearly concerned with the same issue. ${ }^{10}$ Justin draws a sharp contrast between those "who acknowledge the God who is the Creator of All" (Dial. 34.8) ${ }^{11}$ and those who "blaspheme the Creator of All" (Dial. 35.5). He reiterates his opposition to the latter in Dial. 80.4, when he refers to his rivals as "so-called Christians" who "blaspheme the God of Abraham and the God of Isaac and the God of Jacob."

In this chapter, I will analyze Justin's statements about these demiurgical "heretics" and explore their function within the Dialogue's larger argument. The first section highlights the unusual nature of Justin's decision to discuss at some length differences among Christians in a text that purportedly records an engagement with outsiders. It commences with an analysis of the various negative connotations that dissent carried with it in the Greco-Roman world. Division in a community, city or nation was routinely seen as indicating a variety of problems, ranging from the absence of divine favor to issues with the community's foundational laws or principles. Consequently, it is unsurprising that when authors of other early Jewish and Christian texts presented their tradition(s) to outside audiences, they stressed their unity and contrasted it with the discord among rival traditions, a point that will be developed by analyzing a number of contemporary documents, including Josephus's Contra Apionem and the Acts of the Apostles. This common rhetorical strategy puts in stark relief Justin's decision to speak about internal divisions at some length in a conversation with outsiders (i.e., Trypho and his friends) and raises a question that is rarely asked: Why did Justin discuss heretics in the first place? Why this attention to internal division in an ostensible engagement with outsiders?

The second part of the chapter argues that Justin's references to internal division may be explained by considering the rhetorical function of these heresiological passages in Justin's conversation with Trypho. I suggest that Justin strategically employed the notion of heresy to present Trypho and his friends with a form of Christianity devoid of some of what was most problematic and offensive to many Jews. These passages have a clearly apologetic function, which is underscored by the absence of heresiological language in instances where Justin distances himself from certain views that were congenial to potential Jewish converts.

The third part of the chapter argues that despite the rhetorical advantages that heresiology afforded, Justin was aware of the negative associations that internal dissent carried with it, and therefore sought to limit the potential offense of the existence of "heresy" among Christians in various ways. Specifically, he framed it as 1) the fulfillment of prophecy; 2) similar in nature, but less extensive than the divisions among philosophical schools; and 3) less problematic than the "heresies" among Jews. This last element assumes particular significance in the present context; Justin insists that "heresy" is both more deeply rooted and more extensive among Jews than it is among Christians. ${ }^{12}$ The clearly apologetic 
function of this argument calls into question the historical reliability of these passages, which in turn challenges scholarly reconstructions of Jewish sectarianism and heresiology that hinge upon these sections of the Dialogue.

The fourth and final part of this chapter considers what all this was intended to communicate to the Dialogue's audience, which, as I argued in Chapter 2, must have consisted first and foremost of Justin's own social circle. It is obvious that Justin sought to convey to them that demiurgical Christians were "heretics." I suggest that rather more is going on, though, because the notion and "technology" of "heresy" were not yet widespread or frequently adopted in the mid-second century. Justin's demonstration of the utility of heresiology in an engagement with outsiders may therefore be read as an argument in support of heresiology itself. Justin's strategies to undercut the potential damage of drawing attention to dissent among the Christians by portraying it as the fulfillment of prophecy and less extensive than the divisions among philosophers and Jews contributed to this effort because it communicated to his fellow Christians that there were no serious disadvantages to the hardline approach that he advocated. Justin, then, sought to convince his audience not just that demiurgical Christians were misguided, but that a heresiological response to them was both necessary and advantageous.

\section{Part 1: unity and dissent}

Justin's focus on implementing clear boundaries among self-identified Christians and his decision to discuss these divisions at some length in the Dialogue must be considered in light of contemporary discourses about unity and dissent, and the associations that both carried in the Greco-Roman world. Unity was an important theme in political and social discourse. The significance of homonoia ("concord") was stressed at least as early as the fifth century BCE, but the concept became especially prominent during the second century CE. ${ }^{13}$ Allen Brent has argued that homonoia was "the predominant political and religious concept in the discourse of the Second Sophistic." 14 Dio Chrysostom, who flourished about half a century before Justin, would likely have concurred. In one of his many speeches on homonoia he states:

Everyone has always praised concord both in speech and in writing. Both poetical texts and the writings of philosophers are full of its praises and all who have published histories with an eye on the lessons offered by the events have shown concord to be the greatest of human goods. And while many of the sophists have dared to offer arguments that run contrary to common expectations, only with respect to concord have they not contrived to carry this out; they have not contrived, that is, to argue that concord is something not both noble and beneficial.

$$
(\text { Or. 38.10) })^{15}
$$

The importance of concord is apparent not only from literary evidence such as that provided by Dio Chrystostom, but also from material evidence that attests 
the cults of the Greek goddess Homonoia and her Latin counterpart Concordia. ${ }^{16}$ There is significant numismatic evidence as well: a considerable number of coins from the period between Domitian and Gallienus commemorate and advertise the homonoia of Greek cities. ${ }^{17}$

This emphasis on unity is unsurprising given the significance it was considered to have for the current and future wellbeing of a community. Alan Thompson has collected a wealth of evidence demonstrating that unity was widely considered in the Greco-Roman world to indicate that a community enjoyed good leadership and was based on, and governed according to, a good constitution and effective laws. In other words, the degree to which a law or constitution was successful could be measured by the extent to which it promoted unity among the people. Moreover, as Thompson shows, unity was seen as characteristic of effective and successful peoples that not only survived but also were likely to flourish and conquer others. Dissent, on the other hand, elicited opposite associations. It was regarded as characteristic of a community with incapable leaders, built on inadequate laws and unlikely to succeed. ${ }^{18}$

Such political discourse had clearly theological features as well. Only the heavenly city of the gods enjoys perfect concord, according to Dio Chrysostom (Or. 36.22 ), and this city was meant to be a model for earthly forms of government. Indeed the "father of gods and men," the "wisest and eldest ruler and law-giver ... the leader of all the heaven and lord of all being" offers "his own administration as a pattern" so that all may enjoy "complete friendship and concord" (36.31-32). ${ }^{19}$ In another speech, Dio refers to the "signs sent by the gods to teach us to live in concord with one another" $(\mathrm{Or} .38 .18){ }^{20}$ Unity was both a prerequisite and the result of living in accordance with the divine. Homonoia was regarded as a divine blessing, which not only meant that those experiencing homonoia were divinely blessed, but also that those who claimed a divine connection ought to demonstrate homonoia. Dio makes this point in yet another speech on concord: "peace and concord and friendship with one another is fitting for those whose city was founded by gods" $(O r .39 .2){ }^{21}$ This reality is a two-way street, Dio suggests, for if citizens maintain homonoia they will gain the favor of the divine: "[For] is it not evident that not only those in power, but also the gods, give heed to those who live in concord, while those who live in discord do not even hear each other?" (Or. 39.4). ${ }^{22}$ According to this logic, the manifestation of dissent in a community would suggest that it had fallen out of divine favor or, even worse, perhaps was never on good terms with the gods at all.

Dissent would also indicate the presence of error. Unity was frequently associated with truth, while error and dissent, the opposite pair, were likewise closely related. For example, according to Pliny the Elder, the many disagreements among medical practioners rendered the entire discipline of medicine suspicious (Nat. 29.1-7). The same logic was applied to philosophy. The Skeptics famously pointed to dissension among philosophers in support of their view that there was no value to dogmatic philosophy. ${ }^{23}$ And for Philo of Alexandria, the discord among philosophers indicated that they had failed to obtain the knowledge they were after. ${ }^{24}$ 
Particularly significant in light of his close connections to Justin's thought is Numenius, ${ }^{25}$ especially his treatise On the Dissension of the Academy from Plato, which unfortunately has been preserved only in a number of extended quotations in Eusebius's Preparation for the Gospel. Numenius criticized later Platonists for not remaining in agreement with Plato's teaching and contrasted the discordant state of affairs among the Platonists with that of the Pythagoreans (Fr. 24). The latter were unified in closely following the founder of their tradition, which contributed to Pythagoras's extraordinary reputation, Numenius claims. He puts even more emphasis on the point by also contrasting the Platonists with the almost universally reviled Epicureans. According to Numenius, "it is a fact that, for the most part, later Epicureans do not say anything at all that contradicts themselves or each other or Epicurus." ${ }^{26}$ The Epicureans therefore enjoy "continual harmony with each other." ${ }^{27}$ Numenius identifies two important outcomes of this unity among the Epicureans: 1) they could rightly be called sages ("they agreed to share the opinions of a wise man, and they themselves, because of this, fittingly have the benefit of that designation"), ${ }^{28}$ and 2) it explains the Epicureans' past, present and future success ("For this reason they had and have and, I would think, will have eager members"). ${ }^{29}$ Drawing on some of the political themes surveyed above, Numenius likened the Epicureans to "a true polity, not torn by faction, having a single mind and a sole purpose." ${ }^{30}$

The roots of the discord among the Platonists could be traced back to the tradition's founding figures. Socrates was misunderstood by his disciples, according to Numenius, and Plato

combined subjects in a manner neither conventional nor obvious. Discussing each as he considered fitting, he hid them between the visible and the invisible. Although he wrote with purpose, he caused the discord that arose after him along with diversity of doctrines, albeit not out of envy or malice. But I do not want to speak words that are not favorable about the ancients. ${ }^{31}$

This passage demonstrates that just as in politics, dissension within a philosophical tradition could be seen as the result of failure on the part of the founder. Numenius did not place the blame exclusively at the feet of Socrates and Plato, but nevertheless implied that their failure to communicate clearly was at the root of the disunity among the Platonists (as well as the Stoics).

In sum, there is considerable evidence that dissent in a community or intellectual tradition carried a great number of negative associations in antiquity. Internal dissent was frequently seen as the result of a problematic set of laws, an ineffective constitution, and inept leadership. A community that experienced disunity was regarded as weak and unlikely to be prosperous or victorious. It could be assumed, moreover, that this group was either paying insufficient attention to the divine example of perfect homonoia or was for some reason not blessed by the gods. And finally, in the case of an intellectual community such as a philosophical 
school, dissent suggested that the community's ideology was corrupt and their founding figure(s) incompetent.

\section{Unity and apologetic}

In light of all this, it should not be surprising that in ancient Jewish and Christian apologetic literature, the norm was to insist on the unity of one's own tradition while depicting rival traditions as suffering internal fracture. Acts of the Apostles, for instance, stresses the unity that Jesus-believers enjoyed. ${ }^{32}$ This emphasis is especially apparent in Acts 4 and 5 when Luke summarizes the life of the Christian community. Acts 4:32-33 describes how "the whole group of those who believed were of one heart and soul, and no one claimed private ownership of any possessions, but everything they owned was held in common ... great grace was upon them all." Later, in Acts 5:12, Luke stresses how they were "all of them, of one

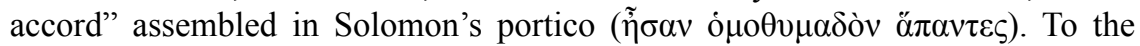
extent that there were tensions among them, these were almost always quickly resolved $(6: 1-7 ; 10: 1-11: 18,15: 1-40)$.

In the presentation of Acts, this unity among Christians stands in marked contrast to the division in the Hellenistic cities. There was a schism among the Iconians (14:40), Thessaloniki was in a state of uproar (17:5, cf. 17:8), and the situation in Ephesus approximated $\sigma \tau \alpha \dot{\sigma} \sigma \varsigma$ ("division, dissent," 19:40). The contrast with the Jews is even sharper. In the account of Paul's appearance before the Sanhedrin in Acts 23, Luke twice mentions that there was $\sigma \tau \alpha \dot{\sigma} \sigma ı \varsigma(23: 7,10)$ among the Pharisees and the Sadducees. As a result, the assembly was split ( $\dot{\varepsilon} \sigma \chi i \sigma \theta \eta \tau$ ò $\pi \lambda \tilde{\eta} \theta$ os [23:7]). The lawyer Tertullus maintained, according to Luke, that there were

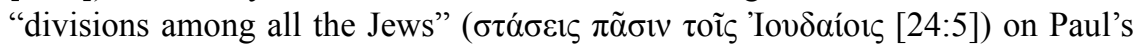
account. Other examples of disagreement among the Jews are found throughout Acts $(2: 12-13 ; 4: 1-4 ; 5: 16-17 ; 13: 44-50 ; 14: 1-2 ; 17: 4-5,12-13 ; 19: 8-9)$. In his final reference to the Jews, Luke states that the Jewish leaders who visited Paul in

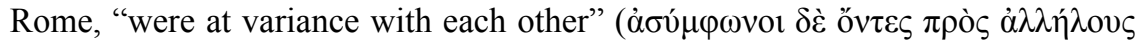
[Acts 28:25]). ${ }^{33}$ Acts clearly utilizes unity and dissent as apologetic tools, drawing on the associations with unity and dissent prevalent in the Greco-Roman world. Christian unity is stressed because it implies the soundness of the founding principles of "the Way" and suggests that its victory is inevitable. The dissent that is so prevalent among the Jews, on the other hand, signals the presence of broader problems and foreshadows the Jews' inevitable demise.

This same set of associations is operative in Josephus's Against Apion, a treatise that is especially interesting because it is the only known piece of Jewish literary self-defense from Justin's period and offers an apology for the very tradition that Justin seeks to trump in the Dialogue. ${ }^{34}$ Unity and dissent were areas of contestation in the battle that Josephus was waging with the Egyptian Apion. Josephus cites the division among the Egyptians as a sign that they are inferior to the Jews (2.65-67, cf. 1.225-226) who enjoy a great deal of harmony, as Josephus stresses time and again $(2.68,2.169-70,2.145-46,2.151,2.281-83,2.193-96,2.293-94)$. 
He makes the point most forcefully in 2.179 when he credits the study of the Law with "our remarkable concord" and claims that

holding one and the same conception of God, and not differing at all in life-style or customs, produces a very beautiful harmony in [people's] characters. Among us alone one will hear no contradictory statements about God, such as is common among others - and not just what is spoken by ordinary people as the emotion grips them individually, but also in what has been boldly pronounced among certain philosophers, some of whom have attempted to do away with the very existence of God by their arguments, while others eliminate his providence on behalf of mankind. Nor will one see any difference in our living-habits: we all share common practices, and all make the same affirmation about God, in harmony with the law, that he watches over everything. As for the habits of daily life: that everything should have piety as its goal, one could gather even from women and slaves ... [We] have taken the sole expression of both wisdom and virtue to consist in doing or thinking absolutely nothing contrary to the laws as originally promulgated. It would be reasonable to take that as evidence that the law was extremely well laid down; for the test of experience shows up those that do not have this quality as needing amendment. What finer law could one invent? What could one bring from elsewhere as an improvement? What about the whole structure of the constitution?

Josephus's claim of complete unity is remarkable in light of the diversity that characterized Second Temple Judaism and it stands in tension with his own claims elsewhere. ${ }^{35}$ It is nonetheless historically plausible that Jews enjoyed at least a reputation for harmony. ${ }^{36}$ This unity among the Jews proves, Josephus argues, that "the law is extremely well laid down" and that there is nothing that could possibly improve on the Jewish "constitution." Their unity establishes the superiority of the Jewish people and their constitution over all others. ${ }^{37}$

Josephus's last reference to the unity of the Jewish people occurs in the final, summary paragraph of his second book: "Thus, I would be bold enough to say that we have introduced others to an enormous number of ideals ... (for) what could be more profitable than concord with one another and neither to fall out in adverse circumstances, nor in favorable ones to become violent and split into factions...?" (2.293-94). ${ }^{38}$ Unity is paramount, Josephus insists, and it is the Jewish Law that is able to provide that unity. Adhering to the ideals of the Mosaic Law is the best way to gain or retain homonoia and thereby avoid stasis. For Josephus, then, unity was a major strength of the Jewish way of life.

As one would expect in light of both Acts and Josephus, Christian apologists also claimed that they promoted and experienced unity and they did not normally discuss internal dissent. Especially noteworthy in this regard is Athenagoras's Embassy, which has been called "essentially a rewriting of Justin's (first) Apology 
in more intellectually respectable terms." ${ }^{39}$ This document lacks any mention of "heresies," ${ }^{40}$ and in this regard Athenagoras is far more typical than Justin. ${ }^{41}$ Indeed, Justin's own student Tatian contrasted the discord among the philosophers with the harmony enjoyed by the Christians in his Oratio ad Graecos. ${ }^{42} \mathrm{He}$ claimed that the philosophers "express opinions that contradict themselves, and each one utters whatever happens to come to mind. And there are many causes of friction between them, for each one hates the other and they opine against themselves" (3.7). ${ }^{43}$ Tatian compared such disagreements with the concord among Christians: "You who lack harmony, since you have factitious doctrinal traditions, oppose those who do live in harmony with each other" (25.4). "We," Tatian asserts, "have no use for variety of doctrine" (32.1). ${ }^{45}$

Working in the opposite direction, Celsus, ancient Christianity's most famous critic, did draw attention to Christian disunity. His treatise The True Logos, only accessible to us in mediated form through Origen's Contra Celsum, was written around the time that Justin flourished. ${ }^{46}$ In this treatise, Celsus drew attention to divisions among Christians at least twice and implied that their presence intimated the error of Christian beliefs. ${ }^{47}$

In light of this combined evidence from Jewish and Christian sources, Justin's willingness to discuss internal divisions in what is (at least ostensibly) a conversation with outsiders is striking. Of course, in $1 \mathrm{Apol}$. Justin also drew attention to internal dissent, but in that case the reason was evident: as we have seen in Chapter 1, he sought to persuade the Roman government to turn against the "heresies," so he could hardly not mention them. Moreover, referencing his opponents allowed him to address the problem that Christians were associated with criminal and immoral activities. These acts were committed not by true Christians but by "so-called" ones, Justin suggested.

But what motivated his references to the heresies in the case of the Dialogue? It is clearly not the case that Justin was simply oblivious to the negative associations that dissent carried in the Greco-Roman world. In 1 Apol. 44.10 he claims that Greek philosophers and poets "are proven to lack accurate understanding whenever they contradict themselves." ${ }^{" 48}$ And in Dial. 2, which will be discussed in more detail below (pp. 108-109), he dismisses contemporary Greco-Roman philosophy precisely on the basis of its divisions. Justin was evidently aware of the difficulties that dissent might conjure up, so why did he discuss intra-Christian differences at all in the Dialogue? It could simply be the case that this is yet another instance of Justin addressing an issue that was more relevant to his internal audience than to Trypho (cf. Chapter 3), but I suggest that more is going on.

\section{Part 2: heresiology and the conversation with Trypho}

The passages in the Dialogue in which Justin engages difference among Christians are largely intelligible, I propose, as part of Justin's attempt to persuade Trypho and his friends of the truth of his form of Christianity. This becomes clear when we consider the grounds on which Justin rejects "other" Christians. 
As argued throughout this study, Justin was particularly concerned with Christian demiurgism. In the context of a conversation with Jews, the apologetic appeal of excluding from the Christian community demiurgists who criticized the Jewish God is straightforward: by denying them the label "Christian," Justin presented Trypho and his companions with a form of Christianity that was much more acceptable to them. The forcefulness of Justin's heresiological model, which does not claim that there are "good" and "bad" Christians, but rather that his opponents are not Christians at all, is crucial in this connection. Christianity, as Justin construes it, has nothing at all in common with these "blasphemers" of the Jewish God.

In Dial. 35, in addition to censuring his rivals for "blaspheming" God, Justin also criticized them for claiming that it is acceptable to eat meat offered to idols (35.1). The issue came up because Trypho expressed concern that there were people among the Christians who "eat meat sacrificed to idols and say that there is no harm in that." ${ }^{49}$ Eating such meat was something that virtually all Jews unequivocally rejected.$^{50}$ Trypho's comment that some Christians consume meat offered to idols is therefore much more than a passing observation on some random detail. It signaled that Trypho was familiar with a form of Christianity that was entirely incompatible with Jewish sensibilities. Instead of seeking to persuade Trypho and his friends to join a group that included members who regarded idol meat consumption as unproblematic, Justin argued that those selfproclaimed members were not, in fact, members at all. Doing so allowed him to present Trypho with a form of Christianity - one opposed to and free from consumption of idol meat - that must have been considerably more attractive to him and his companions.

In Dial. 80, again in response to a comment by Trypho, Justin identified as "heretics" those who blaspheme the Creator and who "say that there is no resurrection of the dead, but claim that their souls are taken up into heaven at the moment they die. ${ }^{~}{ }^{51}$ In the early rabbinic tradition, the resurrection of the dead became a virtual article of faith. ${ }^{52}$ Banishing the denial of the resurrection to the realm of heresy accordingly resulted in a form of Christianity that was more compatible with contemporary Jewish thought and was hence more attractive to Justin's interlocutors. In all of these instances, then, Justin's references to "heresy" are understandable in terms of his efforts to persuade Trypho (and Jews more generally). Firmly rejecting notions that were deeply problematic in the eyes of many Jews allowed Justin to present them with a form of Christianity that was less offensive to them.

That this apologetic interest motivated Justin's deployment of heresiological rhetoric in the Dialogue is strongly suggested by his much milder response to what he considered incorrect notions that must have been congenial to many Jews. It is striking indeed that, for all his interest in heresy, Justin did not dismiss the possibility of legitimate and acceptable difference entirely. ${ }^{53}$ In the Dialogue at least, Justin sometimes refrains from labeling fellow believers with whom he disagrees heretics. What their errors-that-are-not-heresy have in common is that they either 
were held by Jews or were relatively attractive to many Jews. In Dial. 47.1, for instance, we read:

\begin{abstract}
Again Trypho inquired, "If someone who is aware that such is the case and knows that this one (Jesus) is the Christ, i.e. that he both believes and obeys him, if he wants to observe these things (the Mosaic commandments), will he be saved?" I said, "It seems to me, Trypho, that someone like that will be saved, unless he really exerts himself to persuade other people - I mean Gentiles who were circumcised from all error through Christ - to keep these (commandments) like him, by saying that they will not be saved unless they observe them. ${ }^{" 54}$
\end{abstract}

From many passages in the Dialogue, including the preceding section (Dial. 46), it is evident that Justin believes that trying to observe the Mosaic Law is misguided. But he does not reject this as heresy. The idea that one could become a Christian and still remain loyal to Jewish traditions must have been an attractive option to potential believers with a Jewish background. So, although Justin forcefully excludes ideas (along with the people who promote them) that he dislikes and are difficult or even impossible for many Jews to accept, he leaves much more room for what he considers wrongheaded notions that were attractive to many Jews.

We encounter this more lenient approach again in Dial. 48.4, when Justin once more notes an area of disagreement but refrains from dismissing dissenters as heretics:

For there are some, friends, I said, from your people who confess him to be the Christ but are of the opinion that he was a human being of human origin. I do not agree with them, not even if the majority who hold the same opinion as I in these matters would say so. For we have been ordered by Christ himself not to be persuaded by human teachings but by what is proclaimed by the blessed prophets and taught by him. ${ }^{55}$

As in Dial. 47, the alternative position articulated here is congenial to (potential) Jewish believers. This is clear from the phrase "some ... from your people who confess him to be the Christ ... are of the opinion that he was a human being of human origin," and is confirmed by the opening lines of the next paragraph: "It seems to me, said Trypho, that they who say that he was a man ... speak more persuasively ... for we [Jews] all expect that Christ will be a man of human origin ..." (Dial. 49.1). ${ }^{56}$ Other sources likewise suggest that Christians with a Jewish background sometimes preferred to see Jesus as a "mere" human being. ${ }^{57}$ Justin clearly disapproves of this idea, but the language of his response to it is relatively mild. In light of the vigorous and sometimes violent nature of subsequent christological controversies, Justin's tolerance at this point is striking indeed. He states that

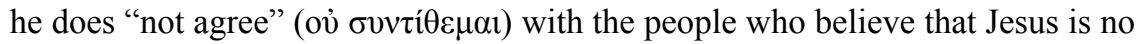
more than human, but he refrains from disputing the authenticity of their faith, 
accusing them of spreading demonically inspired teachings or otherwise implying that they are heretics.

The final passage in which Justin notes diversity without resorting to heresiology is Dial. 80. The chapter opens with the question of whether Jerusalem will be rebuilt, an issue that had apparently already been discussed. This earlier passage cannot be easily identified in the manuscript,$^{58}$ but evidently Justin had told Trypho that he was convinced that, as Trypho puts it, Jerusalem would be rebuilt and that the Christians "would be assembled there and would rejoice together with the Christ, along with the patriarchs and the prophets and those of our people [=the Jews]" (Dial. 80.1) ${ }^{59}$ Now, Trypho wants Justin to confirm that this is his view. Justin responds by saying that it is indeed as "I already confessed to you previously" (Dial. 80.2). ${ }^{60}$ However, Trypho thinks that Justin might have taken this position to "get the better of" ( $\pi \varepsilon \rho \iota \kappa \rho \alpha \tau \varepsilon i v)$ Trypho and his friends and not because this was his true conviction (Dial. 80.1). Whence such suspicion? This passage must be understood in light of the literary setting of the Dialogue. Trypho, and perhaps his friends too, were refugees from the recent war (Dial. 1.3), i.e., the Bar Kochba revolt. After that conflict Jews were banned from Aelia Capitolina, as Jerusalem was now called. In this context, Justin's claim that Jerusalem would be rebuilt and would be open to Jews as well sounded too good to be true. So it is not surprising that Trypho suspects that Justin has taken this position primarily because of its appeal to his Jewish interlocutors. I suggest that this is the sense in which we are to understand the phrase "Do you really expect this to happen, or, did you come to this confession in order to get the better of us in these inquiries?" (

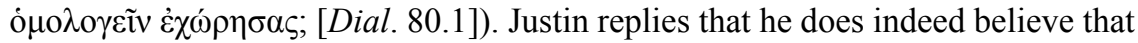
the rebuilding of Jerusalem will take place and that he did not take this position simply because of its persuasive appeal to his audience. He notes, though, that "many true Christians with pure and godly views" do not agree (Dial. 80.2). ${ }^{61}$ At this point, Justin again allows a degree of difference among Christians. He argues that although it may not be the majority view, one can be a Christian and believe in the literal rebuilding of Jerusalem (as indeed he himself does). Justin's form of Christianity can therefore accommodate more Jewish ways of following Jesus even if that implies the presence of difference among Christians. These non-heresiological passages complement Justin's forceful rejection of forms of Christianity that were particularly antithetical to traditional Jewish ideas, and they underscore the apologetic interests that informed Justin's deployment of the notion of heresy.

\section{Part 3: the problem of dissent}

Justin's references to discord among Christians, then, facilitated his appeal to his Jewish interlocutors. But despite its advantages, it remained hazardous to allow the impression of internal dissent, given all the negative associations that it carried (as outlined in Part 1 of this chapter). In this section, I will argue that Justin was 
aware of this risk and that various passages in the Dialogue can be read as attempts to (preemptively) minimize it.

On a fundamental level, the idea of "heresy" itself is a way of constructing unity while addressing difference. At the heart of "heresy" is the construal of a person, group or idea, as simultaneously and paradoxically both insider and outsider. ${ }^{62}$ J. Z. Smith observed that "while the 'other' may be perceived as being either LIKE-US or NOT-LIKE-US, he is, in fact, most problematic when he is TOO-MUCH-LIKEUS, or when he claims to BE-US. It is here that the real urgency of 'a theory of the other' emerges." ${ }^{63}$ The "heretic" is among the most "urgent" kinds of "other," because (s)he is someone who claims and appears to belong to "us." The label "heresy" functions to dispute that notion. The deviance of the "heretic" is of such a nature that it precludes the possibility of a person's ongoing membership in a group according to the one labeling that person as such. Indeed, for Justin, being a "heretic" and being a "Christian" are mutually exclusive (Dial. 35.2, 80.4). One is either a Christ-ianos or a Valentin-ianos, or a Basilid-ianos, etc. (cf. Dial. 35.6). Those consigned to the "heresies" are excluded from being (true) "Christians," which in turn means that the "Christians," as construed by Justin, enjoy a great deal of unity. Although talk of hairesis drew attention to difference among so-called Christians, Justin argues that, in fact, so-called Christians are not Christians at all, which implies the absence of any significant differences among "real" Christians.

Although Justin's heresiological approach therefore had the potential to construct a sense of Christian unity, he must have realized that merely reclassifying certain believers as non-Christians was not a fully effective solution to the problem of dissent. From his point of view, they may not have been Christians, but he was evidently aware that from the perspective of many others - including the heretics themselves - they were Christians and hence continued to undermine Christian unity. So Justin developed a number of other strategies to undercut possible objections on the basis of Christian difference. First, he presented Christian dissent as the fulfillment of prophecy, which meant that dissent confirmed rather than undermined the veracity of the Christian message. Second, he insisted that (Greco-Roman) philosophy was at least as divided as "Christianity." And, third, he argued that the Jews suffered worse dissent than the Christians. We will briefly discuss the first two and spend more time on the third strategy, which assumes particular importance in the context of the Dialogue. Justin's argument that the Jews were at least as divided as the Christians was perhaps particularly urgent in light of the Jews' reputation for unity, which, as we have seen, could be cited as evidence of the superiority of the Mosaic Law. ${ }^{64}$

\section{Fulfilment of prophecy}

One way to neutralize the possibility of seeing dissent as an indication of weakness or problems on the part of the Christians was to argue that the rise of the heresies came about in fulfillment of prophecy. In Dial. 35, immediately after Trypho mentions that some Christians eat meat offered to idols, Justin states: 
Because there are such men who profess themselves to be Christians and profess the crucified Jesus as both Lord and Christ yet do not teach his teachings but the teachings that originate with the spirits of deception, we, the disciples of the true and pure teaching of Jesus Christ, become more faithful and more steadfast in the hope that has been announced by Him, for the things that he, anticipating the events, said would happen in his name we see being fulfilled in concrete reality. For he said: "Many will come in my name, outwardly clothed in sheep's clothing, but inwardly they are ravaging wolves," and "There will be schisms and heresies," and "Watch out for the false prophets, who will come to you, outwardly clothed in sheep's clothing, but inwardly they are ravaging wolves," and "Many false Christs and false apostles will rise up and they will mislead many of the believers."

(Dial. 35.2-3) $)^{65}$

As noted above, dissent could be interpreted as a failure of the group's leadership as well as its founder. Justin employs the proof-from-prophecy argument here in order to claim that in this case the presence of dissent in effect strengthened the authority and reliability of the founder and leader (Jesus) and, by extension, of his community (the Christians), because Jesus had already foretold that "schisms and heresies" would appear. Dissent was not an unforeseen or unanticipated problem, but part of the divine plan from the beginning. Justin, in conclusion, notes that "in no way does any word or action of [Jesus] seem reprehensible to us" (Dial. 35.7) ${ }^{66}$ Perhaps this should be read as a direct attempt to refute the suggestion that dissent among Christians should be blamed on their movement's founder.

Justin again cites Jesus's prediction of "heresies and false prophets" in Dial. 51.2 and he returns to this theme once more in Dial. 82:

He said that we would be killed and hated for the sake of his name and that many false prophets and false Christs would come in his name and that they would mislead many, which is indeed (currently) the case.

(Dial. 82.2) ${ }^{67}$

In this context too, Justin shows awareness that internal dissent potentially constituted a powerful objection to his message. "If you discover such men also among us, do not because of them blaspheme and exert yourself to misinterpret (the Scriptures)," he says (Dial. 82.4). ${ }^{68}$ The focus here, though, is slightly different from Dial. 35, because Justin stresses that the Jews also have their share of "false teachers" and "false prophets." So, he says "if you discover such men also among us...." This constitutes another main line of argument that Justin develops in the Dialogue in connection with the problem of dissent. Justin seeks to eliminate the possibility that dissent could be held against the Christians by arguing that dissent was at least as prevalent among the Jews. He develops this argument more fully in other passages, as we will see below. First, however, we turn to Justin's argument 
that Christian dissent is unproblematic given that the philosophical tradition was at least as fractured.

\section{Comparison with philosophy}

In $1 \mathrm{Apol}$., Justin had appealed to the analogous situation among philosophers to argue that just as philosophy is not abandoned because of internal dissent and the existence of "false" philosophers, neither should the Christian message be rejected (1 Apol. 4 and 7, see above, pp. 14-16). In the Dialogue, Justin strikes a more critical tone vis-à-vis contemporary philosophy, and insists forcefully on the disunity among philosophers:

Philosophy is truly the greatest possession and most precious to God, to whom it alone leads us and unites us, and they in truth are holy men who have applied their minds to philosophy. But what philosophy is and for what reason it was sent down to the people has escaped the majority. Otherwise, there would not be Platonists, or Stoics, or Peripatetics, or Theoretics, or Pythagoreans, since this understanding of philosophy is always one and the same. I would like to tell you why it has become so diversified. They who first grasped philosophy and for that reason became illustrious were succeeded by people who did not investigate the truth but being amazed only by their [predecessors'] perseverance and self-control and the unusual nature of their words regarded what each had learned from his teacher as true. Then they also transmitted to those following them such and similar things, which is why they are called by the name of the father of their teaching.

(Dial. 2.1-2) $)^{69}$

This passage indicates that Justin was fully aware that dissent could be problematic. It was widely seen as an indication of error, and that is precisely the line of argument that Justin follows here in his critique of contemporary philosophy. For Justin, philosophy "is truly the greatest possession," but only in its pristine state, not its current divided one. In Dial. 35, Justin refers back to this passage when he discusses the Christian haireseis:

And there are some among them who are called Marcionites, others Valentinians, others Basilidians, others Saturnilians, and others still are called by another name, each one named after the author of their conviction, in the same way that each of those who consider themselves to be philosophers, as I stated at the beginning, thinks he ought to carry the name of the father of the system of philosophy that he adheres to.

(Dial. 35.6) ${ }^{70}$

Justin argues that just as the Platonists (etc.) are not true philosophers, the Marcionites (etc.) are not real Christians. Hence the diversity among those who claim 
to be Christians is comparable to that among the philosophers. And in the same way that philosophy itself remains "truly the greatest possession," so too the true Christian teaching (which for Justin, of course, is also "the only sure and useful philosophy" [Dial. 8.1]) relinquishes none of its value despite its contemporary divisions. $^{71}$

\section{Division among the Jews}

The most important way in which Justin sought to limit the potentially damaging implications of diversity among the Christians was by insisting that dissent, and indeed the very phenomenon of hairesis, was even more widespread and more deeply rooted among the Jews.

\section{Dial. 80}

We noted above that in Dial. 82 Justin insisted on the presence of division and false teaching among the Jews. Moreover, Justin suggested in that passage that Christian "heresy" is a continuation of similar phenomena among the Jews: "Just as there were false prophets in the presence of the holy prophets among you, there are now also many among us" (Dial. 82.1) ${ }^{72}$ According to Justin, in the same way that God's gifts of prophecy have been transferred from the Jews to the Christians, so too have false prophecy and false teaching. ${ }^{73}$ The deviancy that is currently manifest among the Christians was therefore present among the Jews first.

In making this argument, Justin built on Dial. 80, where he had discussed Christian haireseis and explained their status by drawing an analogy with seven Jewish haireseis. Justin suggested in this passage that the Jews were at least as divided, if not more so, than the Christians, and that "heresy" was as much a problem for Jews as it was for Christians:

(3) For I told you that those who are so-called Christians, but are really atheistic and impious heretics, teach blasphemy, godlessness and stupidity in all respects. ... (4) They dare to blaspheme the God of Abraham and the God of Isaac and the God of Jacob, who even say that there is no resurrection of the dead, but claim that their souls are taken up into heaven at the moment they die. Do not consider them Christians, just as, if one were to rightly examine it, one would not consider to be Jews the Sadducees or the similar haireseis of the Genistae and the Meristae and the Galileans and the Hellenians and the Pharisees, the Baptists (and do not be offended when you hear me say all that I think). One would consider them so-called Jews and children of Abraham and "confessors of God with their lips," as God himself cried out, "having their heart far from him." (5) But I and, if there are others who are in all respects rightthinking Christians, we know that there will be a resurrection of the flesh 
and a thousand years in a Jerusalem that is rebuilt, adorned and enlarged, as the prophets Ezekiel, Isaiah and the others agree. ${ }^{74}$

The Jews, this passage suggests, faced considerable divisions of their own. Justin's mention of seven Jewish haireseis may therefore have been intentional, because the number suggests a sense of comprehensiveness. Hegesippus also lists seven Jewish "heresies" (apud Eusebius, Hist. eccl. 4.22.7) as does Epiphanius (Pan. Proem I, 3.6; Anaceph. 1.14-20). ${ }^{75}$ In order to more fully understand the work that this list is doing for Justin, we must try to pinpoint the various groups that he enumerates here.

\section{GENISTAE AND MERISTAE}

That genistae reflects the Hebrew minim is broadly accepted by scholars. The stem of genistae is genos, which is the word nearly always used in the LXX to translate min. Justin's use of genistae in this particular context tells us a number of significant things that have been previously overlooked. It intimates that the Hebrew term $\min$ was used to refer to deviant Jews in this time, which means that the Dialogue, which predates the redaction of the oldest rabbinic texts by at least several decades, offers the earliest evidence for this particular use of this term. It follows that the rabbinic concept of $\min$ was not developed under the influence of or in response to Justin's heresiology. ${ }^{76}$

While we can identify the background of Justin's use of genistae with some degree of plausibility, the identity of the meristae is a much more difficult question. Perhaps it refers to "schismatics," but certainty in the matter is entirely elusive. ${ }^{77}$

\section{GALILEANS}

Daniel Boyarin has argued that "the Galileans can plausibly be identified with the minim gliliim (Galilean heretics) of the Mishna Yadayim," but Boyarin's phrasing at this point is a bit imprecise. ${ }^{78}$ The manuscripts of $m$. Yad. 4.8 all have the singular מין גלילי minim gliliim," but only for a singular Galilean min. The adjective Galilean may well have little more than a geographical (or cultural) significance in this context and there is little reason to think that it refers to a member of a specific heretical group. The common scholarly association of Justin's "Galileans" with the followers of Judas the Galilean who appears in Acts 5:37 and in Josephus (J.W. 2.118, Ant. 18.9 and 18.23 ) seems equally possible. ${ }^{80}$

\section{HELLENIANS}

Because the Hellenians are otherwise unknown, some scholars have emended the text in Dial. 80.4 from hellenianoi to hellelianoi (i.e. Hillelites). ${ }^{81}$ But even if this emendation is accepted, not all issues are resolved, because as far as we know the "House of Hillel" was not regarded as a heretical group by anyone in 
antiquity. ${ }^{82}$ Many scholars therefore opt for a connection with the Hellenists (hellenistai) found in Acts. ${ }^{83}$ The difference between the suffixes - ianoi and -istai is not particularly significant. ${ }^{84}$ And in many ways the hellenistai of Acts 9:29 seem to be a Jewish rather than a Christian group. ${ }^{85}$

\section{BAPTISTS}

In the case of the Baptists there are essentially two possibilities for identification. The first is that Justin had the so-called "morning baptizers" in mind, a group mentioned in Hegesippus (apud Eusebius), Epiphanius, and the Apostolic Constitutions (cf. t.Yad. 2:20). ${ }^{86}$ It is telling, however, that Justin does not use the word hemerobaptistai ("morning baptizers"), but simply baptistai ("baptists"). A second option therefore seems at least equally likely, namely that Justin referred to the disciples of John the Baptist mentioned in Acts 19:3-4, whom the text says Paul encountered in Ephesus many years after John's ministry. ${ }^{87}$

\section{PHARISEES AND SADDUCEES}

The Pharisees and the Sadducees are well attested in a wide range of ancient sources, but their presence in Justin's list of heresies is puzzling. ${ }^{88}$ As L. W. Barnard put it: "The crux interpretum of the list is ... the inclusion of the Sadducees and Pharisees. It seems totally incomprehensible that Justin ... could describe these as heresies." ${ }^{89}$ Shaye Cohen (followed by Daniel Boyarin) notes that "the tannaim refused to see themselves as Pharisees" and argues that "this rabbinic ideology is reflected in Justin's discussion of the Jewish sects: there are Jews, i.e., the 'orthodox,' and there are sects, among them the Pharisees, who scarcely deserve the name Jew." ${ }^{90}$ Indeed, while the rabbis regarded figures elsewhere identified as Pharisees as part of their tradition, they did not use the term "Pharisee" to refer to them. There is, however, no polemic against the Pharisees anywhere in Tannaitic literature. In $t$. Ber. 3:25, which, as Boyarin recognizes, is "approximately a century later than Justin" 91 the paroshim are connected with the minim. But, as Boyarin also notes, the reference is to separatists, not to the Pharisees of the Gospels or Josephus. ${ }^{92}$ Moreover, this and most other explanations of the presence of the Pharisees are hard-pressed to account for Justin's inclusion of the Pharisees among the heresies here and his reference to them in Dial. 137.2 as "your Pharisaic teachers," which recognizes that the Pharisaic tradition constituted an important component of the Jewish leadership of Justin's time. ${ }^{93}$

\section{THE SEVEN JEWISH HAIRESEIS AS A CHRISTIAN CONSTRUCT}

Scholars have frequently taken this list of seven Jewish heresies as a reliable reflection of contemporary Jewish sectarianism and heresiology. Daniel Boyarin, for instance, claims with reference to this passage in Dial. 80 that "Justin seems to have had very good knowledge of Jewish heresiology, indeed, even of some of 
its obscure corners." ${ }^{\text {9 }}$ Some of Boyarin's identifications on which this assessment is based are contestable, as I have suggested above. The only identification on which we are in complete agreement, namely that of the genistae as minim, speaks against Boyarin's conclusion that Justin "had very good knowledge of Jewish heresiology." The minim are, contrary to Justin's suggestion, not a single "heresy" in rabbinic discourse but a more general term for deviants. ${ }^{95}$

There are other, more fundamental problems with regarding Justin's list as an accurate reflection of contemporary Jewish heresiology. One such difficulty is that Jewish heresy lists are otherwise poorly attested. Heresy catalogues do not seem to have been in use among Jews at this time, or at least they are not attested in surviving contemporary Jewish literature.$^{96}$ And related to this, evidence that Jews used the word hairesis in a pejorative sense at all is extremely limited ${ }^{97}$ Another problem with the notion that Justin's account reflects intimate knowledge of even the "obscure corners" of Jewish heresiology is that it is not so easy to square this with recent assessments of Justin's familiarity with the contemporary Jewish world. Whereas early studies were optimistic about his knowledge of Jewish traditions ${ }^{98}$ more recent work has come to the conclusion that "Justin's knowledge of Judaism was meager at best." 99

Moreover, Justin himself does not in fact claim in this passage to be describing contemporary Jewish discourse. He does not say that these groups are regarded as heresies by other Jews, but rather that "if one were to rightly examine it" one would consider them as such. The language is not descriptive, but prescriptive: one should consider them only "so-called Jews and (so-called) children of Abraham." Justin indicates later on in the Dialogue that he is aware that Jewish leadership in his day did not normally do so:

Your teachers beguile both themselves and you when they suppose that the eternal kingdom will most certainly be given to all who belong to the offspring of Abraham according to the flesh, even if they are sinners and unfaithful and disobedient to God. The Scriptures show that this is not the case.

$(\text { Dial. 140.2) })^{100}$

While in Dial. 80 Justin describes how one should see the matter, here he describes how the Jewish teachers of his day actually did see it: according to Justin, Jewish teachers of his day did not regard deviant Jews as "non-Jews." Justin disagrees with this understanding ("The Scriptures show that this is not the case"), and this matches his insistence in Dial. 80 that if "one were to carefully consider" the matter, one would conclude that certain Jews should be regarded as non-Jews.

The point Justin is seeking to make in Dial. 80 is that the Jews were as divided as the Christians. The Christians are admittedly plagued by "heresies," but if one considers the matter carefully, one would recognize that the same is true for the Jews also. There are "heretics" in both groups, Justin suggests, even though the Jews fail to identify them as such and wrongly insist that all descendants of Abraham will share in the "eternal kingdom." 
In order to drive home the point that divisions were not characteristic of, or unique to, the Christians, but that Jews were facing similar problems, a substantial list of deviant Jewish groups was needed. The number seven communicated the extensive and comprehensive nature of Jewish "heresy." Justin had heard about the minim ("genistae") and perhaps also about the meristae (whoever exactly they may have been), but a list of only one or two Jewish "heresies" would speak more against Justin's argument than in support of it.

It is a good possibility that Justin's search for additional Jewish heresies led him to Acts of the Apostles, and that he derived all the other items on his list from this source. ${ }^{101}$ Acts was a logical place for Justin to look for heresies, since it is one of the few literary sources to use the word hairesis in reference to Jewish groups. ${ }^{102}$ As far as we know, the only other contemporary texts that referred to Jewish groups as haireseis are the works of Josephus. But if Josephus were Justin's (main) source, we would expect him to have included the Essenes, who are mentioned alongside the Pharisees and Sadducees in Josephus's discussion of Jewish haireseis (cf. Ant. 13:171; Vit. 10). Their absence is remarkable indeed and difficult to explain on any previously offered theory. ${ }^{103}$ But the omission of any reference to the Essenes can be readily explicated if Justin derived his information from Acts, because there too, the Essenes are absent. By contrast, Acts does describe the Pharisees $(15: 5,26: 5)$ and the Sadducees (5:17) as haireseis, which explains their surprising presence on this list. Justin's inclusion of the Pharisees in spite of his awareness that they could be regarded in his time as "your [i.e., the Jews'] teachers" (Dial. 137.2) signals how important it was to get to a seven-item list that properly expressed the prevalence of "heresy" among the Jews. ${ }^{104}$ The remaining groups can all be traced back to Acts as well. As we have seen, the Hellenians can be plausibly connected with the Hellenists (Acts 6:1, 9:29, 11:20), the Galileans with the group led by Judas the Galilean (5:37), and the Baptists with the followers of John the Baptist (Acts 19:3-4). In Acts, all of these are depicted as Jewish groups that are to some degree distinct from the Jewish mainstream. In each of these cases, the hypothesis that Justin derived the groups from Acts is as likely as the alternatives that have been suggested. And even if in one or two instances preference is given to some other putative derivation, the central role that Acts appears to have played in the formation of this list still stands. Influence of Acts at this point is further suggested by the traces of that book that may be found elsewhere when Justin refers to haireseis (see below, pp. 150-52).

The likelihood that Justin drew on Acts in composing this list has important implications, inter alia, for the question of how well the list reflects contemporary Jewish reality. The reading advanced here suggests that Justin's list is essentially a Christian construct, not a reliable overview of contemporary Jewish currents based on deep knowledge of Judaism. Accordingly, the list should not be used to reconstruct contemporary Judaism(s) nor should it be taken as a reliable guide to contemporary Jewish heresiology.

Boyarin recognizes that Justin's list is not a direct representation of Jewish heresiology. He regards it as an "elaboration," noting in particular that he considers it 
doubtful "that any rabbinic circle ever had such a list of Jewish heresies as Justin cites for them; it feels just so "Christian." "105 I would go further and argue that Justin's "Jewish heresiology" is virtually entirely a Christian construct. Its format, the use of the term hairesis, and many of its components are Christian projections. ${ }^{106}$ Justin's use of Christian categories is a direct result of his efforts to curb the problems created by Christian dissent, which in this case took the form of suggesting that "heresy" was at least as established and widespread among the Jews. ${ }^{107}$ Justin had heard of the minim, but he was otherwise not particularly well-informed about contemporary Jewish discourse. ${ }^{108}$ His presentation is not a reliable account of any alleged Jewish heresiology. And indeed, as we saw, Justin himself does not in this passage claim to report how contemporary Jews saw the matter.

It should moreover be noted that even if one does take this passage as Justin's attempt to describe contemporary Jewish heresiology, it does not follow that his description is reliable. Justin was clearly capable of making bold, inaccurate claims that served his apologetic aims. In Dial. 71.1-2, for instance, a passage discussed in the previous chapter, Justin insists that "(Your teachers) have completely removed many scriptural passages ... on the basis of which it can be demonstrated clearly that the crucified one was announced as both God and man and as the one who would be crucified and would die" (cf., e.g., Dial. 72.1-4, 73.1-6). ${ }^{109}$ Such passages indicate that Justin himself was poorly informed or that he counted on his ability to convince relatively poorly informed Jews like Trypho. Or perhaps his primary concern at such moments was with his internal, predominantly Christian audience, who would have little problem accepting such claims. In any case, it cannot be assumed that any of Justin's claims about Judaism, including any notions about contemporary Jewish heresiology, are necessarily accurate. ${ }^{110}$

\section{Dialogue 62}

This interpretation of Justin's list of heresies in Dial. 80, which reads it as an attempt to alleviate the problem of Christian disunity by insisting on considerable dissent among Jews, finds support in Dial. 62, where Justin also mentions a Jewish hairesis. Here, once again, he seems intent on maximizing Jewish difference.

In the preceding chapter (Dial. 61), Justin had advanced the argument that the "other God" (i.e., Jesus) was begotten by God "as a beginning before all creatures" (Dial. 61.1). In support, he cited the famous passage from Proverbs where Wisdom states, "the Lord begot me in the beginning of his ways" (Prov. 8:22). It is at this juncture that Justin turns to Gen 1:26-27, which he claims supports his argument (Dial. 62.1):

(1) This very thing, my friends, the word of God spoke also through Moses, ${ }^{111}$ indicating to us that the God whom he made known spoke in this same sense at the creation of humanity, saying: Let us make humanity in our image and likeness ... (2) And so that you would not, altering the words previously spoken, say what your teachers say, namely either 
that God said Let us make to himself, in the same way that we also often say Let us make to ourselves when we are about to make something, or that God said Let us make to the elements, that is, to the earth and the other elements in like manner, out of which, as we comprehend, humanity came into being, I will again investigate the words spoken by Moses himself, on the basis of which we can determine beyond dispute that he conversed with a being endowed with reason, different from him in number. (3) These are those words: And God said, Behold Adam has become as one of us, able to recognize good and evil. Surely, As one of us indicates that there were a number of entities coexisting with each other, two at the least. That he was speaking to angels or that the human body was a product of the angels, which is taught by what is called a heresy among you, I would not consider to be true, nor do I think that the teachers of that heresy are able to prove it. (4) But this offspring, which was in truth emitted from the Father, was with the Father and the Father conversed with it, as the word discloses through Solomon. For this very thing that Solomon calls wisdom, was both beginning, before all creatures, and also became an offspring by God's agency. ${ }^{112}$

The crucial passage for our purposes is Dial. 62.3: "That he was speaking to angels or that the human body was a product of the angels, which is taught by what is called a heresy among you, I would not consider to be true, nor do I think that the teachers of that heresy are able to prove it." Importantly, this group is not in the first place a "heresy" or "sect" in Justin's view, but it is a Jewish hairesis - it

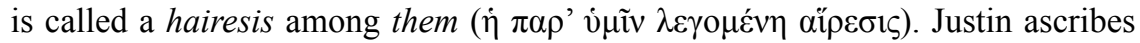
"teachers" (plural) to this particular hairesis, suggesting that it is a relatively sub-

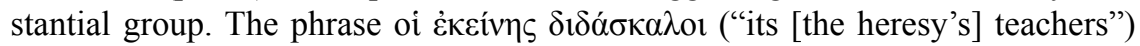
sets up a contrast with oi $\delta 1 \delta \alpha ́ \sigma \kappa \alpha \lambda o r ~ \dot{v} \mu \tilde{\omega} v$ ("your teachers") and emphasizes the degree of dissent among the Jews. The internal Jewish debate is not between teachers and lay people, but between various groups of teachers. Justin contrasts the different views of these teachers with a single Christian teaching. Among the Jews there are multiple competing, mutually exclusive interpretations. But among the Christians there is, according to Justin's presentation, only one. The highly rhetorical nature of this presentation comes into focus when the teachings allegedly propounded by this Jewish group are analyzed, because the ideas that Justin ascribes to this hairesis are by no means uniquely Jewish. I argue that what Justin terms "a Jewish hairesis" held views that were shared by certain Christians and that Justin must have been aware of this. Justin, then, sought to maximize discord on the Jewish side. By insisting on the presence of hairesis among them, he made Christian dissent look not nearly so bad by comparison.

According to Justin, the hairesis of Dial. 62 teaches: 1) that God was speaking to angels when he said "Let us create humanity" (Gen 1:26) and "Adam has become as one of us" (Gen 3:22); and 2) that the human body was the work of the

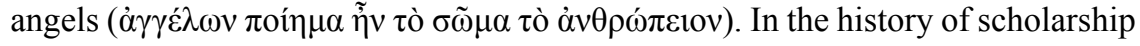


these two teachings have often been conflated, but the latter is distinct from the former. ${ }^{113}$ The second teaching of this hairesis is not that angels alongside God were responsible for the human body; it mentions angels exclusively. ${ }^{114}$ Moreover,

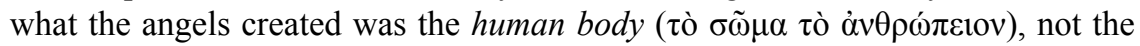
human being as a whole ( $\dot{o} \alpha \theta \rho \omega \pi \circ \varsigma)$. The focus on the body is a departure from the language of Genesis and certainly not without significance for the Platonically minded Justin, who would not simply have equated the body with the entire human being. The first tenet of this heresy, namely that God addressed the angels in Gen 1:26 and 3:22, is found in a range of Jewish and Christian sources. It would not be an unfair summary of Philo's thought. ${ }^{115}$ It parallels the interpretation of a number of rabbis according to Genesis Rabbah ${ }^{116}$ and other rabbinic texts. ${ }^{117}$ And it was also prevalent among Christian groups. Irenaeus claims that Simon Magus (A.H. 1.23.2, 1.23.3), Menander (1.23.5), Saturninus (1.24.1), Basilides (1.24.4), and Carpocrates and his followers (1.25.1) all held that angels were involved in Creation. ${ }^{118}$ What Justin ascribes to a "Jewish heresy" is therefore in reality a notion that was shared by several Jewish and Christian groups. ${ }^{119}$

The second teaching can be more precisely located. The idea that the angels were exclusively responsible for the creation of the human body is a familiar aspect of the anthropogony of texts such as the Secret Book of John. Its narrative distinguishes between the psychical and the material body but it regards both as the work of angels $(19,2-21,14) .{ }^{120}$ The theme encountered here of a creation of the human body by angelic spirits and a subsequent divine intervention that turns that body into a living human being is found in a number of other Nag Hammadi treatises as well (see, e.g., On the Origin of the World 112, 25-116,8; The Nature of the Rulers 87, 23-89,17), and Irenaeus records a version of it in A.H. 1.30.6. ${ }^{121}$ The passage in Adversus Haereses that most closely matches the description of Justin's "Jewish" hairesis, however, is Irenaeus's account of Saturninus (a.k.a. Saturnilus):

Saturninus, following Menander, assumed there is one Father who is unknown to all and who made the Angels and Archangels, Virtues and Powers. But the world and all that is in it was made by certain seven Angels. Man too is the work of Angels. When a shining image appeared from above from the sovereign Power and they were not able to hold fast to it because it immediately ascended again, he said that they exhorted each other, saying, "Let us make man after an image and likeness." 122 When this first-formed-man was made and was not able to stand erect because of the weakness of the Angels, but wriggled on the ground as a worm, then the Power on high had pity on him, because he was made after its likeness and he sent a spark of life which raised him up and set him upright and made him live.... He says the God of the Jews is one of the Angels.

With Saturninus we have a Christian "heretic" who believed both that the Jewish God addressed angels when he said "Let us make man" and that humanity was the 
product of the angels. Irenaeus and Justin in fact use the same Greek expression, $\dot{\alpha} \gamma \gamma \varepsilon \dot{\lambda} \omega v \pi$ oí $\mu \alpha$ ("product of angels") when referring to this second notion. ${ }^{123}$ The body is not expressly mentioned in the passage from Irenaeus, but it is clearly in view. The product of the angels in the myth is not yet truly alive and can only wriggle on the ground like a worm. It is, in other words, nothing more than a body.

Justin was aware of the Saturnilians. He listed them in Dial. 35.6 among those who "call themselves Christians." According to Irenaeus, other groups and figures mentioned by Justin, such as the Basilideans (Dial. 35.6) and Simon Magus and Menander (1 Apol. 26, 56) also held at least some of the views that Justin associates here with this Jewish "heresy." In light of Irenaeus's discussion, which postdates Justin's by perhaps as little as fifteen years, as well various Nag Hammadi texts mentioned above that confirm Irenaeus's account in broad outline, it is difficult to imagine that Justin was unaware that these and similar ideas were propagated by his Christian rivals. It is not impossible that Justin knew of Jewish groups who accepted this myth as well, and of course, the lines between Judaism and Christianity were not yet drawn clearly or forcefully enough to deem much of anything exclusively Jewish or exclusively Christian. ${ }^{124}$ Nevertheless, it is clear that Justin ascribes these views exclusively to a Jewish heresy and does not mention any (so-called) Christians who adhered to the same notions. ${ }^{125}$ Justin is apparently seeking to minimize the degree of Christian dissent while stressing the extent to which dissent was present among the Jews. In addition, perhaps Justin sought to send a thinly veiled message to his Christian rivals: those who adhere to these ideas are propounding a Jewish teaching. The force of the point derives in no small part from the fact that demiurgical teachers largely disapproved of the "Jewish" aspects of what would later be deemed "orthodox" Christianity (the Jewish God, Jewish Scriptures, etc.). Justin seems to suggest that many of them in reality promote a Jewish teaching. The argument that both the idea of heresy and specific instances of heresy have Jewish roots works both ways: it constitutes an argument against the "heretics" by insinuating that their ideas and conduct are essentially Jewish, while at the same time attacking the Jews by alleging that they are subject to considerable division.

The apologetic function of Justin's references to Jewish "heresies" here ("what is called a heresy among you") and elsewhere, should make us suspicious of claims that there actually was a well-developed Jewish heresiology that influenced him, as has been argued in previous scholarship. Alain Le Boulluec, for instance, maintained that the early Christian notion of heresy was decisively shaped by prior developments among Jews. In his view, central components of Justin's heresiology developed in imitation of contemporary Judaism. ${ }^{126}$ Similarly, Eduard Iricinschi and Holger Zellentin have suggested, specifically on the basis of Justin's frequent references to Jewish haireseis, that "the search for the origin of heresiology points beyond Justin Martyr, toward the Jewish heresiology of or before Justin's time." 27 On my reading, Justin's references to Jewish haireseis have a clear apologetic function and should therefore not be taken as straightforward and reliable descriptions. As noted above, outside of Justin's own writings there 
is remarkably little evidence of a well-developed Jewish heresiology at this point in time. ${ }^{128}$ Justin, then, is perhaps not reporting, but inventing Jewish heresiology. Scholars who posit a Jewish origin for heresiology accordingly run the risk of reifying a rhetorical reconstruction that belongs to the realm of Christian apologetics.

\section{Part 4: heresiology and Justin's internal audience}

To briefly recap what has been argued thus far in this chapter: Part 1 analyzed the various negative connotations of difference and dissent in the Greco-Roman world and contrasted the usual apologetic strategy of emphasizing the unity of one's own tradition with Justin's readiness to discuss internal dissent in the Dialogue. Part 2 explained Justin's reasoning by demonstrating that the passages about Christian "heresies" enabled Justin to dissociate from "Christianity" a number of elements that were particularly problematic for many Jews and thus to present Trypho with as attractive a form of Christianity as possible. Finally, Part 3 argued that Justin not only skillfully exploited the advantages that heresiology had to offer but also guarded against the downsides that talk of "heresy" would inevitably conjure up. Justin sought to undercut the negative associations that dissent among the Christians might elicit by presenting it as 1) the fulfillment of prophecy; 2) similar in character to the divisions among philosophers; and 3) less extensive than the similar "heresies" that plagued the Jews.

The focus of this chapter up to this point has been on the textual world of the Dialogue, that is, on the rhetorical function of these heresiological passages within Justin's conversation with Trypho. This final section will consider Justin's rhetorical aims vis-à-vis his internal audience. On the most basic level, his goal was evidently to impart to this audience that demiurgical Christians were "heretics," i.e. people who claimed they were Christians, but really were not, and that they should be excluded from the Christian community. However, I suggest that the issue is ultimately more complex, because such a hardline stance and categories like "heretic" and "heresy" do not seem to have been widely adopted in Justin's time and these labels certainly did not yet imply established processes of condemnation and exclusion. The concept of "heresy" was still under construction when Justin wrote and no formal exclusionary mechanisms seem to have been in existence. As Peter Lampe, Einar Thomassen, and others have shown, there was no central, uncontested ecclesiastical authority in mid-second century Rome, where the Dialogue was most likely composed. The Christian community consisted of a collection of different groups and individuals who operated largely independently from each other. Before the third century, meetings took place in private homes, which at least partly explains the decentralized nature of this community. Teacher-scholars such as Justin, Valentinus and Marcion were not authorized or controlled by any official body. It was extremely difficult in this context to draw strict boundaries between what and who was and was not "Christian," and the evidence suggests that such boundary drawing was rarely attempted. As Peter Lampe notes: "Before the end of the second century, specifically before the episcopacy of 
Victor (c. 189-99 CE), hardly any Roman Christian group excluded another group in the city from the communion of the faithful." ${ }^{129}$ Marcion ultimately parted ways with other Christians, but it is not clear that he was excommunicated or expelled; more likely, he departed of his own accord. ${ }^{130}$ Cerdo and others also withdrew on their own initiative, ${ }^{131}$ while teachers such as Valentinus and the first generation of his followers appear to have remained part of non-Valentinian Christian groups during their entire lives. ${ }^{132}$

Even so, we should not imagine Christianity prior to Justin as an altogether irenic constellation of various groups. Forceful polemic had been a mainstay of early Christian literature since the time its earliest preserved writings, the letters of Paul, appeared. Although Walter Bauer once made the remarkable claim that Paul "display[s] a spirit of toleration that scarcely knows what a heretic might be,"133 there are many passages in Paul's writings that belie this assessment. In an important corrective to Bauer, Hans Dieter Betz drew attention to such strongly polemical passages as Phil 3 and Rom 16:17-20. ${ }^{134}$ More recently, Robert Royalty has offered a reading of Galatians and 2 Corinthians that effectively highlights Paul's exclusionary polemic. ${ }^{135} \mathrm{He}$ also documents persuasively how this polemic was adopted in the generations following Paul. ${ }^{136}$ Nonetheless, as Lampe, Thomassen and others have shown, such rhetoric did not straightforwardly translate into the systematic and formal exclusion of individuals, let alone the exclusion of groups based on their theological positions. The response to difference remained inchoate and $a d$ hoc in the mid-second century. In practice, the boundaries of the Christian community were not clearly drawn.

In this historical context it did not suffice for Justin to argue that some people were "heretics." He had to make the case that Christians should adopt the underlying logic and "technology" of "heresy." Justin had to persuade his audience that it was necessary to draw strict boundaries and actively deny certain people the label "Christian." Avoiding or ignoring such people was not enough; they had to be completely disowned. Such a hardline stance likely met with resistance, because it was by no means universally adopted either in Justin's time or in the period immediately after. Some may have rejected this insistence on boundary-drawing among Christians by citing Jesus's stress on love and forgiveness or the emphasis placed on concord (homonoia) by such authorities as Paul, Clement and Ignatius. ${ }^{137}$ They would certainly have been aware of the many negative connotations of dissent that were widespread throughout the Greco-Roman world (see Part 1 of this chapter). Drawing strict boundaries between acceptable and non-acceptable forms of Christianity would make the Christians seem divided and, as a result, appear misguided, weak and disorganized. How could the Christian message hold any persuasive appeal to outsiders if the existence of such divisions was allowed or even promulgated and emphasized by insisting that fellow believers were "heretics"?

In light of this, I propose that part of the function of the Dialogue's references to difference among Christians was to demonstrate that adopting a hardline, heresiological approach was both necessary and advantageous. We have seen that Justin strategically employed heresiology to offer Trypho a more attractive 
version of Christianity. Doing so signaled to his internal audience the utility of this approach. Only a form of Christianity that took an uncompromising stance against the demiurgists could have any hope of attaining success with a Jewish audience, Justin suggested. Likewise, Justin's various strategies to alleviate the offense of Christian divisiveness, while clearly functional in the context of the conversation with Trypho, may also be read as a response to (or perhaps a preemptive strike against) those who were wary of Justin's advocacy of clear divisions among selfproclaimed Christians. Justin argued that such divisions were already prophesied by Jesus and that they could be favorably contrasted with the more extreme dissent experienced by Jews and philosophers.

Trypho's role may also be more fully understood against this backdrop. It is surely no coincidence that, as noted above, Trypho is at times the one who draws attention to differences among Christians. To the audience of the Dialogue, this would likely have communicated two important points, each of which speaks in favor of Justin's exclusionary approach. First, Trypho was evidently already aware of differences among Christians. Any objection to heresiology on the basis that it would emphasize diversity was thereby undercut, because outsiders like Trypho were (according to Justin's presentation) already cognizant of significant differences among self-proclaimed Christians. And, second, as a result of these differences, Trypho was confused about what Christians actually believed and his disinclination to accept the Christian message was partly motivated by his incorrect assumptions about what "Christianity" entailed. The previous chapter argued that one of the ways in which Justin explained the lack of Jewish converts was by suggesting that they had encountered counterfeit forms of Christianity that they found offensive. ${ }^{138}$ This implies that it would be in the best interest of "true" Christians to be very clear about who and what qualified as Christian (and who and what did not). In short, Trypho's awareness of Christian difference and simultaneous confusion about what authentic "Christianity" entailed provided support for Justin's heresiological agenda.

\section{Conclusion}

This chapter set out to analyze the import and function of the Dialogue's references to differences among Christians. It argued that Justin's comments about Christian "heresies" had a clear function in the discussion with Trypho. These heresiological moments enabled Justin to present his Jewish interlocutors with a version of Christianity that was maximally appealing to them by forcefully excluding certain practices and notions that were deeply offensive to many Jews (consumption of idol meat, denial of the resurrection of the dead, and, critically important, criticism of the Jewish God). That this strategy was at the heart of Justin's employment of heresiology in his conversation with Trypho is further indicated by the fact that whenever he responds to difference but refrains from banishing the "other" view to the realm of heresy, the difference concerns something that was appealing to a 
Jewish audience (the Messiah as a "mere" human being, the possibility of remaining loyal to the Mosaic Law, the future rebuilding of Jerusalem).

The Dialogue's demonstration that heresiology could function constructively and advantageously in the context of an apologetic and evangelistic appeal constituted a clear commendation of this approach to fellow Christians, in a context in which by no means all were willing to adopt such a hardline stance, and the technology and terminology of hairesis were not yet widely adopted. Those opposed to the approach that Justin takes could argue that insisting on difference and dissent would weaken the Christian movement and message in the eyes of outsiders. In light of the many negative associations that disunity carried with it in the Greco-Roman world, this was an entirely reasonable counter-argument. Evidently aware that internal dissent suggested the presence of error as well many other problems, Justin developed a number of literary strategies to counter potential objections on this basis. The notion of heresy itself had a part to play in this connection, because rather than admitting to difference among the Christians, it insisted that certain "others" were not Christians at all, which meant that the "true" Christians enjoyed a remarkable degree of harmony. Furthermore, Justin presented the existence of dissent among self-proclaimed Christians as the fulfillment of (Jesuanic) prophecy. In this way, rather than suggesting that something was fundamentally wrong with the founder and founding principles of the Christian tradition, the presence of the "heresies" confirmed their veracity and reliability. Most importantly, Justin sought to create the impression that while the Christians were divided among themselves, the situation was even worse among the philosophers and especially among the Jews. He insisted at various junctures that difference in general and "heresy" in particular were more widespread and more deeply rooted among the Jews than among the Christians. The apologetic function of his references to Jewish "heresies" casts serious doubts on the possibility of taking these passages as reliable social or discursive description. I have argued that in Dial. 62 and Dial. 80 in particular, Justin's interest in depicting the Jews as considerably divided skewed his presentation, to the extent that he offers an essentially Christian projection largely uncorroborated by external evidence.

The various lines of argument that Justin develops to present Christian dissent as largely unproblematic evidently have a function on the level of his conversation with Trypho and his friends. However, not least in light of the likelihood that Justin wrote primarily and initially for an internal audience, we must read this defense of Christian dissent against the backdrop of Justin's own secondcentury ecclesiastical context in Rome as well. The arguments developed by Justin to undercut the difficulties raised by the existence of haireseis among the Christians offered a response to those hesitant to draw strict boundaries. ${ }^{139}$ One of Justin's aims, in short, was to establish the advantages of heresiology while demonstrating that its potential disadvantages were limited and ultimately insignificant. 


\section{Notes}

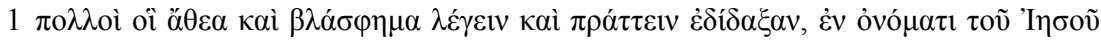

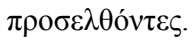

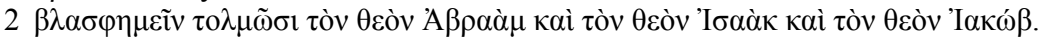

3 See above, p. 3.

4 On hairesis and its development, see the extensive discussion in John Glucker, Antiochus and the Late Academy, Hypomnemata 56 (Göttingen: Vandenhoeck und Ruprecht, 1978), 166-92. It is important to note that the original neutral sense of hairesis remained in use alongside the pejorative use of the term. This may to some extent be the case in Justin as well.

5 See above, p. 2.

6 Cf., e.g., with respect to Dial. 35, François M.M. Sagnard, "Y a-t-il un plan du Dialogue avec Tryphon?," in Mélanges Joseph de Ghellinck, S.J. (Gembloux: Duculot, 1951), 1:178; Skarsaune, The Proof from Prophecy, 167. Although I agree that a good case can be made that structurally some of the pertinent passages appear as digressions or interludes, I do not interpret this as implying that they were unimportant to Justin. Rather, they are important enough that he includes them (forces them in, almost) even when they do not arise naturally in the conversation.

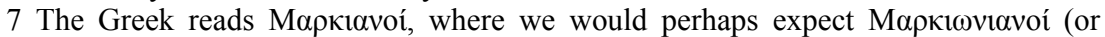

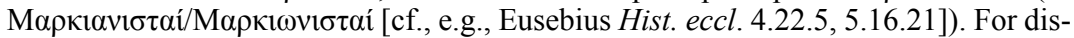
cussion, see Enrico Norelli, "Marcione e la costruzione dell'eresia come fenomeno universale in Giustino Martire," Rivista di storia del cristianesimo 6 (2009): 363-4 n. 4, where much of the pertinent secondary literature is cited.

8 Pierre Nautin, "Conférence de M. Pierre Nautin," École pratique des hautes études, Section des sciences religieuses. Annuaire 90 (1981): 335-6, argues that the Carpocratians were originally also included. Nautin notes that Hegesippus, after mentioning a

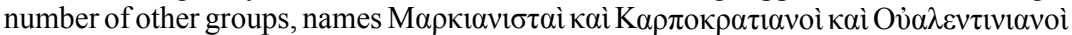

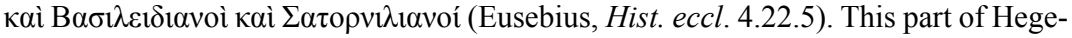
sippus's list, in other words, matches Justin's except for the Carpocratians. There are many possible explanations, however, for the inclusion of the Carpocratians in Hegesippus's list (or rather, for their inclusion in Eusebius's fourth-century version of Hegesippus's list) and there is, accordingly, insufficient warrant to emend Justin's text.

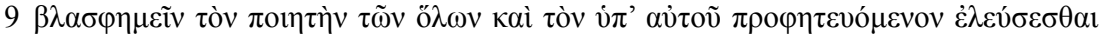

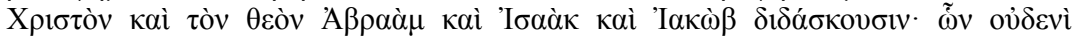

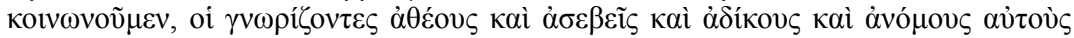

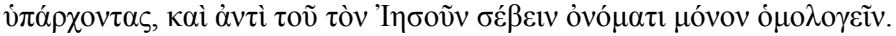

$10 \delta \eta \mu 10 v \rho \gamma o ́ s$ and its cognates occur eight times in $1 \mathrm{Apol}$. and once in the much shorter 2 Apol., but never in Dial.

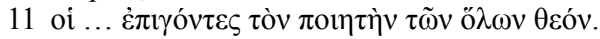

12 The relative unity of "Christianity" and "Judaism" was something that concerned other early Christians as well. The author of the Pseudo-Clementine Epistula Petri, for instance, writes: "Those who everywhere belong to his (Moses's) people keep the same rule with respect to (God's) supreme command and their way of life ... therefore there is among them one God, one Law and one hope. In order then that the same

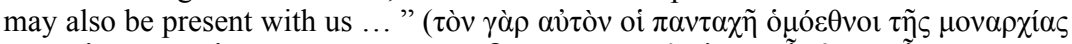

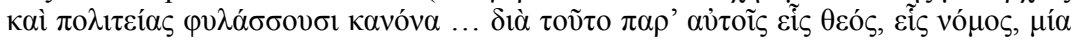

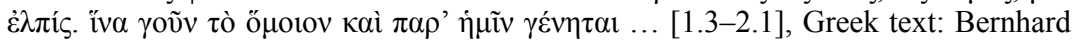
Rehm, Johannes Irmscher, and Georg Strecker, Die Pseudoklementinen. I. Homilien, GCS [Berlin: Akademie-Verlag, 1992]). What follows is a set of instructions to effect the kind of unity among Christians that the Jews were seen to be already enjoying. The author of the Didascalia makes a similar observation and notes in particular the existence of schisms and heresies among the Christians but not among the Jews: "Now 
in like manner also Satan, the tempter, removed (himself) from that people and came against the church. And from thenceforth he does not again tempt that people, because through their evil works they have fallen into his hands, but he is prepared in order to tempt the church and to perform his operation in her. And he has raised up against her afflictions and persecutions, and blasphemies and heresies and schisms. Before, in that time, there were heresies and schisms in that people, but now Satan by (his) evil operation has driven forth those of the church, and has made heresies and schisms" (Arthur Vööbus, The Didascalia Apostolorum in Syriac, vol. 2, CSCO 408 [Louvain: Secrétariat du CorpusSCO, 1979], chap. 23, 211). The author of the Didascalia solved the problem of Christian dissent in the face of Jewish unity by arguing that Satan, the instigator of heresies, had diverted his attention from the Jews to the Christians. This explanation made it possible to construe the absence of unity among the Christians as something positive. The heresies among the Christians indicated that they were in possession of the truth, which is why Satan focused his attention on them. Conversely, the lack of heresies among the Jews is evidence of the absence of anything that Satan might wish to combat. As a people they "have fallen into his (Satan's) hands."

13 See, e.g., Håkan Tell, Plato's Counterfeit Sophists (Washington, DC; Cambridge, MA: Center for Hellenic Studies, 2011), 61-92.

14 Allen Brent, Ignatius of Antioch and the Second Sophistic: A Study of an Early Christian Transformation of Pagan Culture (Tübingen: Mohr Siebeck, 2006), 234.

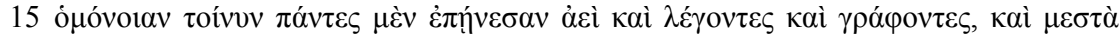

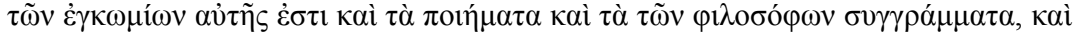

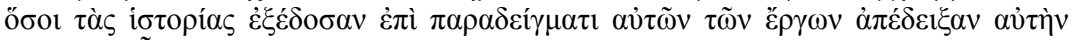

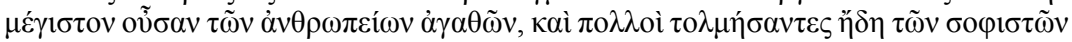

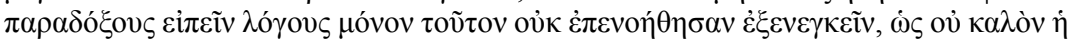

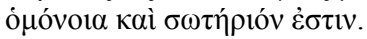

16 On the development of these cults, see Anna Clark, Divine Qualities: Cult and Community in Republican Rome, Oxford Classical Monographs (Oxford; New York: Oxford University Press, 2007); Gaétan Thériault, Le culte d'homonoia dans les cités grecques (Lyon; Québec: Maison de l'Orient méditerranéen; Editions du Sphinx, 1996).

17 See Brent, Ignatius of Antioch and the Second Sophistic, 245, and the literature cited there.

18 Alan J. Thompson, One Lord, One People: The Unity of the Church in Acts in Its Literary Setting, LNTS 359 (London: T \& T Clark, 2008), esp. 18-56, 105-34.

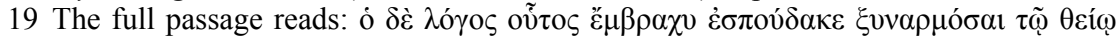

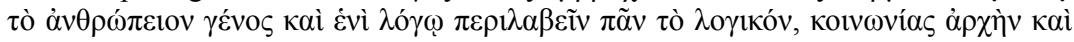

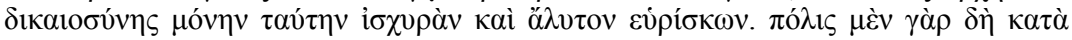

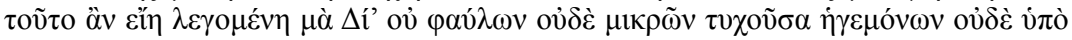

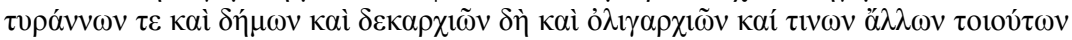

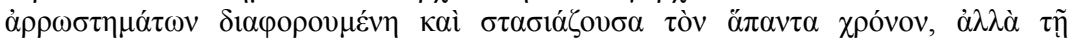

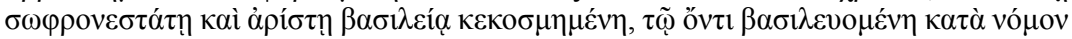

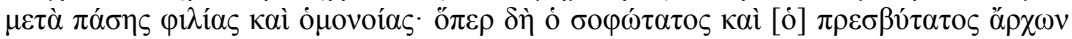

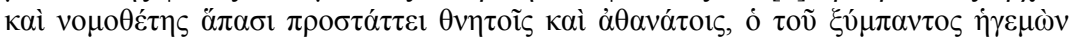

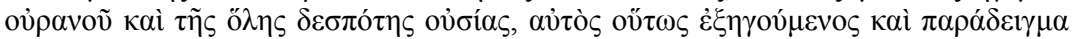

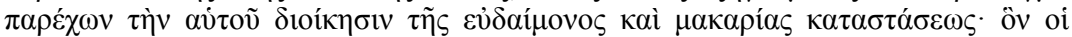

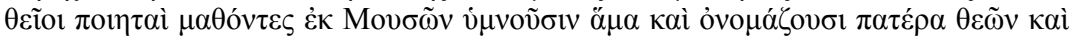
$\alpha \nu \theta \rho \omega ́ \pi \omega v$. LCL translation: "Nay, term (i.e. the word 'city' [polis]) would be applied rather to an organization that is governed by the sanest and noblest form of kingship, to one that is actually under royal governance in accordance with law, in complete friendship and concord. And this, indeed, is precisely what the wisest and eldest ruler and law-giver ordains for all, both mortals and immortals, he who is the leader of all the heaven and lord of all being, himself thus expounding the term and offering his own 
administration as a pattern of the happy and blessed condition, he whom the divine bards, instructed by the Muses, praise in song and call the "father of gods and men."

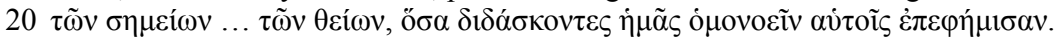

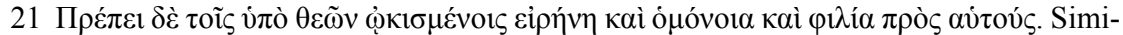
larly, Aelius Aristides, Or. 24.48.

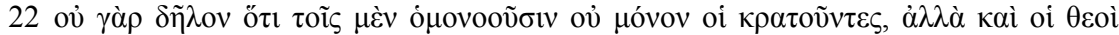

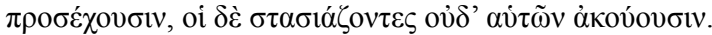

23 Using somewhat technical language, Sextus Empiricus claimed, “discrepancy ( $\delta 1 \alpha \varphi \omega v i ́ \alpha)$ leads us to find that with regard to the object presented there has arisen both amongst ordinary people and amongst the philosophers an interminable conflict because of which we are unable either to choose a thing or reject it, so fall back on suspension" (Hyp. Pyrr. 1.164-65 [LCL]). Cf. Hermeias's Ridicule of the Pagan Philosophers (Diels, DG 651-656), a Christian text deriding the disagreements among the philosophers.

24 Questions on Exodus, Fragment 4: "All the philosophies that have flourished in Greece and barbarian lands have sought after the principles of nature, but were unable to perceive even the least significant one with clarity. Clear evidence: the disagreements and struggles and differences of opinion of those who belong to each school, who refute and are themselves refuted in turn." Greek text according to Françoise Petit, Quaestiones in Genesim et in Exodum: fragmenta Graeca, Les œuvres de Philon d'Alexandrie

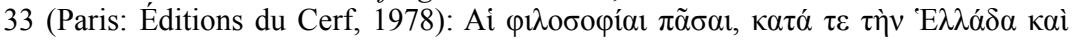

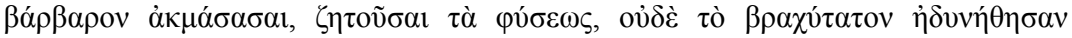

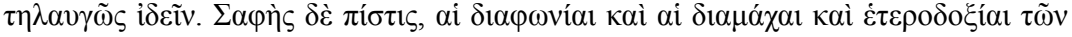

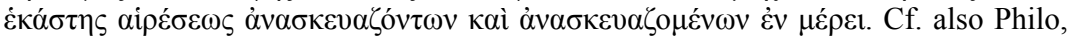
Her. 246-8, Tri Trac. 109-112, etc.

25 See p. 34 n. 43.

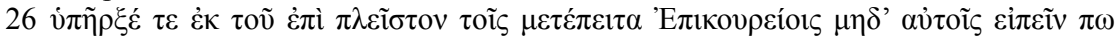

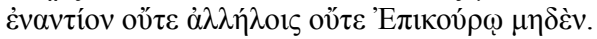

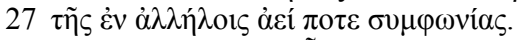

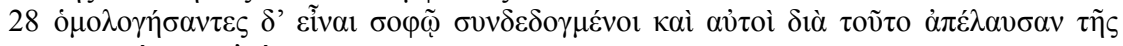

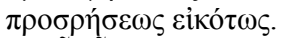

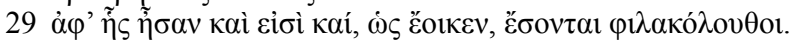

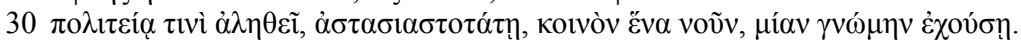

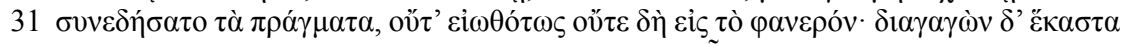

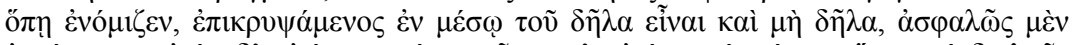

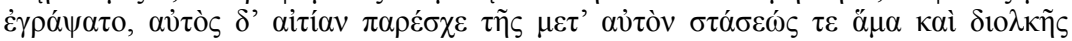

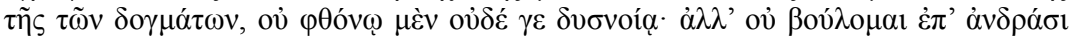

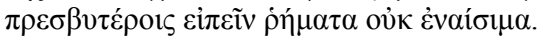

32 On Acts as "apologetic historiography," see Gregory E. Sterling, Historiography and Self-Definition: Josephos, Luke-Acts, and Apologetic Historiography, NovT Supplements 64 (Leiden; New York: Brill, 1992) with the definition of that label on p. 17; and Clare K. Rothschild, Luke-Acts and the Rhetoric of History: An Investigation of Early Christian Historiography, WUNT 2.175 (Tübingen: Mohr Siebeck, 2004). Christian unity is expressed using such terminology as ó $\mu$ o $0 u \alpha \delta \delta$ óv $(1: 14 ; 2: 46 ; 4: 24$;

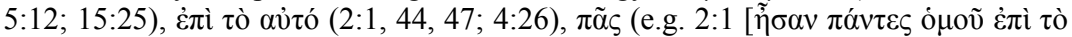

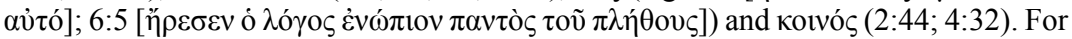
further discussion, see Thompson, One Lord, One People.

33 The word hairesis has a part to play in the contrast that Luke set up between Christian unity and Jewish dissent. Luke refers to the Sadducees and Pharisees as haireseis $(5: 17 ; 15: 5 ; 26: 5)$, but in the voice of Paul refuses that label for the Christians $(24: 5$, 14). As Richard Pervo notes, "The term aipecis ... permits a critique of Judaism, which, unlike Christianity, is rent by sects or factions, a state of affairs that is not compatible with authentic religious belief and practice" (Acts: A Commentary, Hermeneia [Minneapolis, MN: Fortress Press, 2009], 142). 
34 Against Apion was composed between $94 \mathrm{CE}$ and Josephus's death sometime in the early second century (see John M.G. Barclay, Against Apion, vol. 10, Flavius Josephus, Translation and Commentary [Leiden; Boston: Brill, 2007], xxvi-xxviii). Against Apion is an apologia in the technical, rhetorical sense: Josephus is directly responding to charges that have been leveled against the Jews (cf. Barclay's discussion of the work's genre [xxx-xxxvi]), and he himself calls the work an apologia in 2.147.

35 See Louis H. Feldman, "Pro-Jewish Intimations in Anti-Jewish Remarks Cited in Josephus' 'Against Apion'," JQR 78 (1988): 216-17.

36 Cicero in his defense speech for Flaccus said with respect to the Jews, "You know how vast a throng it is, how close-knit (quanta concordia), and what influence it can have in public meetings" (Flac. 66). Tacitus (Hist. 5.5) similarly noted that the Jews "are extremely loyal toward one another (apud ipsos fides obstinata)." While both authors are referring primarily to the Jews at Rome, these passages suggest a general impression of Jewish unity among the Romans that fits with Josephus's claim that the Jews had a reputation for concord (C. Apion. 2.68). John Barclay, although admitting that "the boast is clearly exaggerated," thinks that Josephus's claim of concord is "not completely absurd" (Against Apion, 270-1 n. 704). He offers three reasons in support of this view: 1) "Josephus is speaking here about common beliefs, not political unity." A claim of political unity would be preposterous in light of the infighting during the Jewish war; 2) "The only point of comparison here is belief about the existence and providence of God (2.180). Compared to the Greek philosophical disagreements on those topics, Judean theological diversity appears minor"; and 3) "Judeans were not famous for internal divisions in belief or practice."

There is no question that Josephus is greatly overstating the degree of unity among the Jewish people and this passage cannot be used as evidence for the absence of dissent, hostility or "heresy" among first-century Jews (pace Boyarin, Border Lines, 53-4). However, there does indeed seem to have been a basic degree of unity among the Jewish people. For all the disagreements of various kinds, virtually all Jews at this time agreed on the importance of the Mosaic Law, monotheism (in various forms), and election. This may not seem like very much, but as Barclay notes, it was a lot more than could be said about Greek philosophy (which is offered as a comparandum by Josephus). It was also arguably more than could be said about contemporary "Christianity."

37 Cf. §180: "Among us alone one will hear no contradictory statements about God, such as is common among others."

38 Other pertinent passages beyond the scope of this study include C. Ap. 2.145-46, 2.151, 2.281-83, 2.193-96.

39 Sara Parvis, "Justin Martyr and the Apologetic Tradition," in Justin Martyr and His Worlds, ed. Sara Parvis and Paul Foster (Minneapolis, MN: Fortress Press, 2007), 115-27. See also Bernard Pouderon, Athénagore d'Athènes, philosophe chrétien, Théologie historique 82 (Paris: Beauchesne, 1989), 347-50.

40 Athenagoras, Embassy 2.5 is the only place where Athenagoras alludes to difference among the Christians and even there it is only raised as a logical possibility, not stated as fact.

41 Ad Diognetum, Tatian, and Minucius Felix likewise do not mention Christian "heresies." Tertullian's comparatively brief comments in Apology 46-47 may constitute an exception.

42 On the question of whether Tatian was indeed Justin's student, see Jörg Trelenberg, Oratio ad Graecos = Rede an die Griechen, BHTh 165 (Tübingen: Mohr Siebeck, 2012), 195-203.

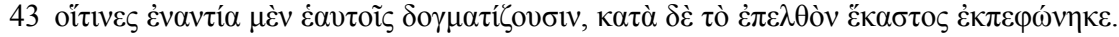

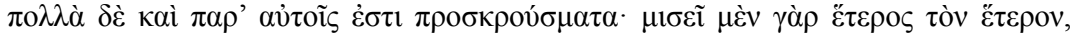

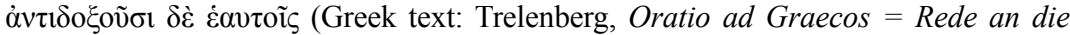
Griechen). Cf. 1.2, where Tatian speaks of the $\sigma \tau \alpha$ ó $1 \zeta$ among the Greeks; also 3.7, 26.5. 


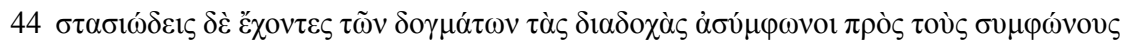
$\dot{\varepsilon} \alpha v \tau o i ̄ \varsigma ~ \delta 1 \alpha \mu \alpha ́ \chi \varepsilon \sigma \theta \varepsilon$.

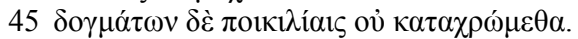

46 It is possible, but by no means certain, that Celsus read Justin's work. For discussion, see Carl Andresen, Logos und Nomos: Die Polemik des Kelsos wider das Christentum (Berlin: Walter de Gruyter, 1955); Henry Chadwick, Early Christian Thought and the Classical Tradition: Studies in Justin, Clement, and Origen (Oxford; New York: Clarendon Press; Oxford University Press, 1984), 11; Osborn, Justin Martyr, 168-70, esp. 169: "(Celsus's) direct acquaintance with Justin is an attractive but unnecessary hypothesis"; Gary T. Burke, "Celsus and Justin: Carl Andresen Revisited," ZNW 76 (1985): 107-16, concludes: "The evidence simply does not support ... a necessary dependence of Celsus on Justin, and in some cases even points away from Justin as Celsus' source" (116).

47 Origen responds to this issue in Cels. 3.10-14 as well as in 5.61-65. There could well have been more discussion of Christian dissent in Celsus that Origen chose not to quote, because Origen notes that Celsus lingers on this point ( $\dot{\varepsilon} \pi \imath 1 \alpha \tau \rho i \beta \varepsilon 1 \gamma \varepsilon$

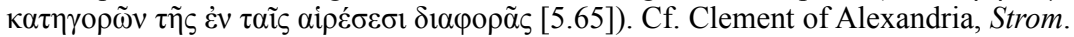
7.89.2.

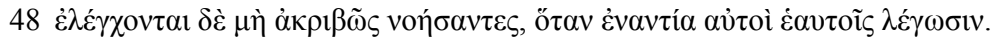

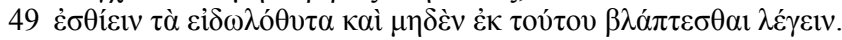

50 See p. 91 n. 51.

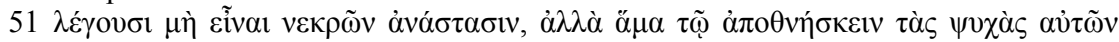

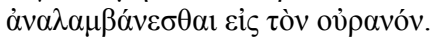

$52 \mathrm{~m}$. Sanh. 10:1 famously includes those who "say that there is no resurrection of the dead" among those who "have no share in the world to come." A number of other traditions imply that denial of the resurrection of the dead renders one a Samaritan (e.g., Sifre Numbers 112; b. Sanh. 90b).

53 This is sometimes overlooked or ignored in discussions of Justin's heresiology. Cf., e.g., Lyman, "The Politics of Passing: Justin Martyr's Conversion as a Problem of 'Hellenization'," 49: "by rejecting all dissent as hairesis, that is, demonized human opinion in contrast to revealed truth, Christianity confirmed its singular authority" (emphasis added).

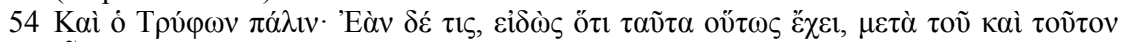

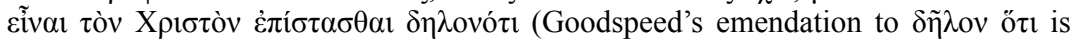

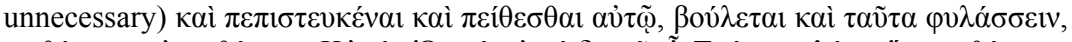

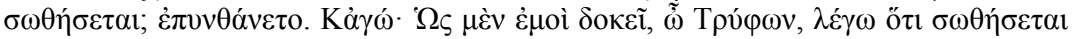

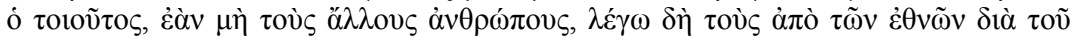

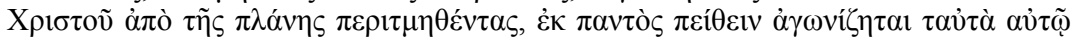

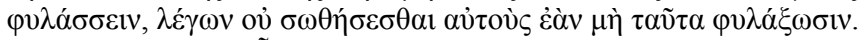

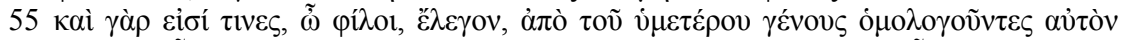

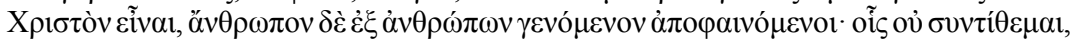

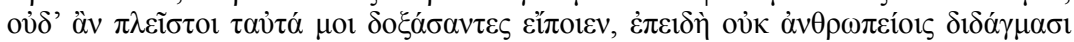

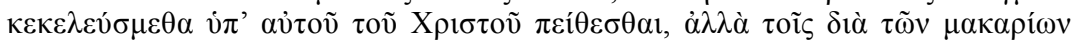

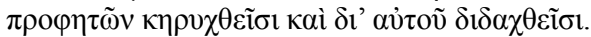

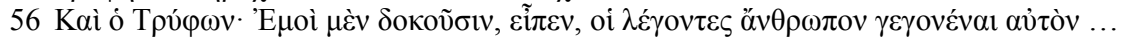

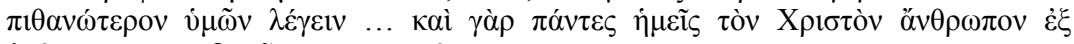

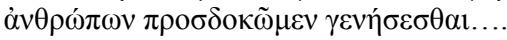

57 E.g., Irenaeus A.H. 1.26.2.

58 This is not the only place where a reference to a previous discussion cannot be located in the manuscript. See, e.g., Georges Archambault, Dialogue avec Tryphon, Textes et documents pour l'étude historique du christianisme, 8, 11 (Paris: A. Picard, 1909), LXXII-LXXIV; Marcovich, Dialogus cum Tryphone, 4-5, with reference to Dial. 79.1, 79.4, 105.4, and 142.1. On the gaps in the manuscript, see above, p. 10 n. 12. 


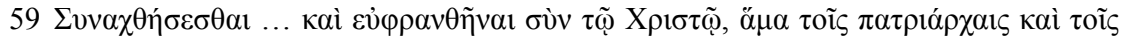

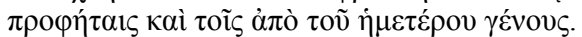

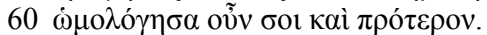

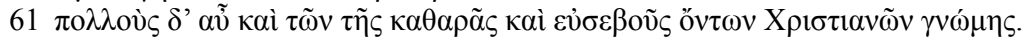

62 Cf. Lester R. Kurtz, "The Politics of Heresy,” AJS 88 (1983): 1087: "heresy refers to an intense union of both nearness and remoteness. Heretics are within the circle, or within the institution; consequently, they are close enough to be threatening but distant enough to be considered in error"; Einar Thomassen, "What Is Heresy, and Why Did It Matter?," in Invention, Rewriting, Usurpation: Discursive Fights over Religious Traditions in Antiquity, ed. Jörg Ulrich, Anders-Christian Jacobsen, and David Brakke (Frankfurt am Main: Lang, 2012), 195: "A heretic is by definition an insider." See also George V. Zito, "Toward a Sociology of Heresy," SA 44 (1983): 125; Lewis A. Coser, The Functions of Social Conflict (Glencoe, IL: Free Press, 1956), 70; Kurtz, "The Politics of Heresy," 1096; Malcolm Bull, "The Seventh-Day Adventists: Heretics of American Civil Religion," Sociology of Religion 50 (1989): 178-9; William E. Arnal, "Doxa, Heresy, and Self-Construction: The Pauline Ekklēsiai and the Boundaries of Urban Identities," in Heresy and Identity in Late Antiquity, ed. Eduard Iricinschi and Holger M. Zellentin, TSAJ 119 (Tübingen: Mohr Siebeck, 2008), 53 n. 8; Jacques Berlinerblau, "Toward a Sociology of Heresy, Orthodoxy, and Doxa," HR 40 (2011): 335.

63 Jonathan Z. Smith, "What a Difference a Difference Makes," in "To See Ourselves as Others See Us": Christians, Jews, “Others" in Late Antiquity, ed. Jacob Neusner, Ernest S. Frerichs, and Caroline McCracken-Flesher (Chico, CA: Scholars Press, 1985), 5.

64 See pp. 100-1 on Josephus. See also Smith, Guilt by Association, 103-104, who offers insightful comments on the apologetic function of Justin's claims about Jewish divisions.

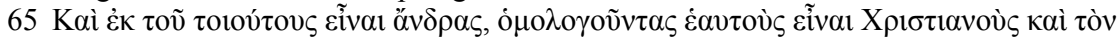

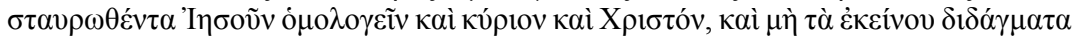

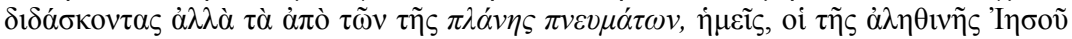

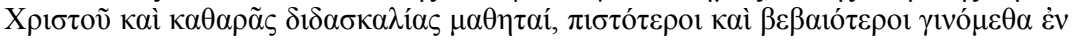

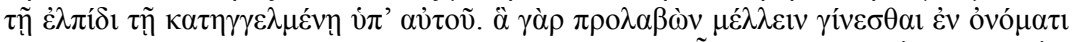

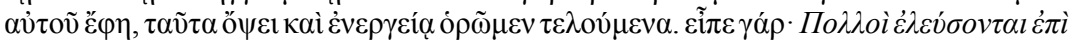

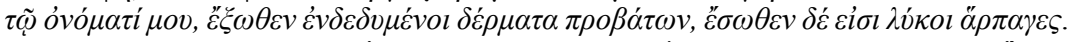

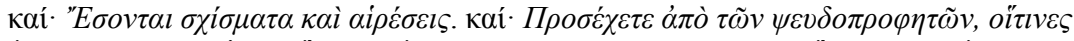

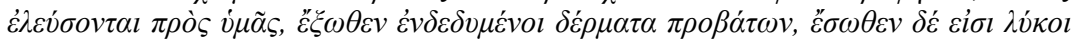

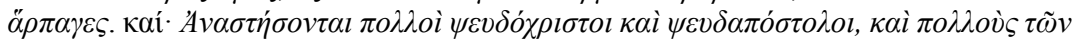
$\pi \imath \sigma \tau \tilde{\omega} v \pi \lambda \alpha v \dot{\sigma} \sigma o v \sigma l v$.

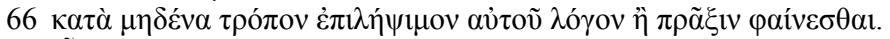

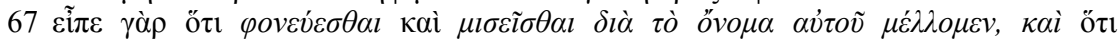

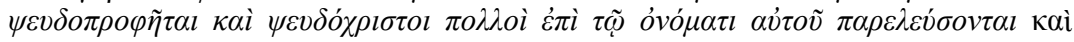

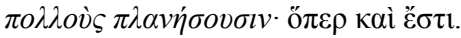

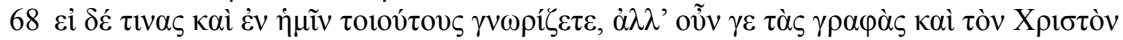

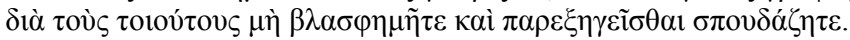

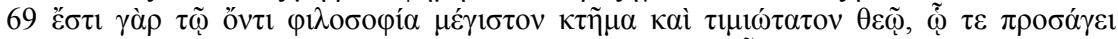

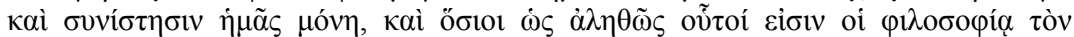

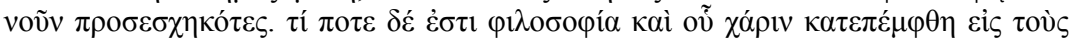
$\dot{\alpha} v \theta \rho \omega ́ \pi 0 v \varsigma, \tau o v ̀ \varsigma \pi \mathrm{o} \lambda \lambda$ ov̀ $\varsigma \lambda \varepsilon \dot{\lambda} \eta \theta \varepsilon v$. [Goodspeed marks this as a question, but Bobi-

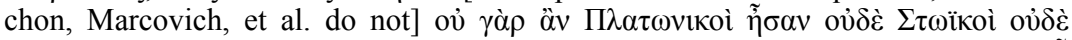

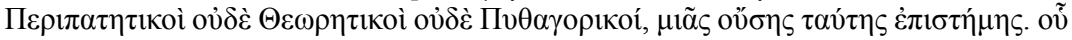

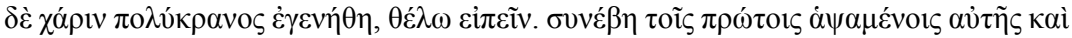

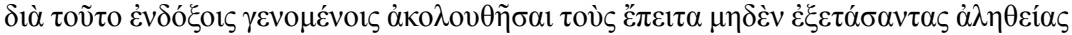

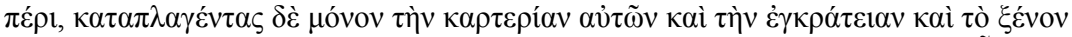

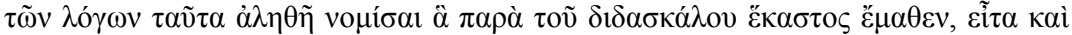

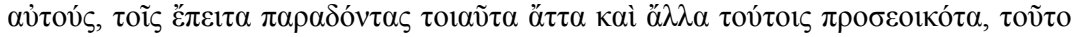

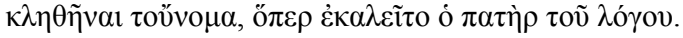




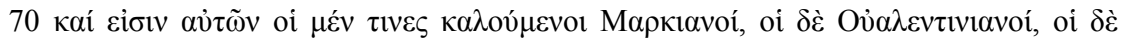

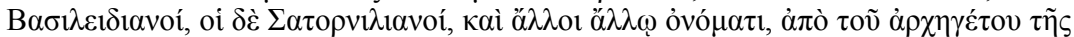

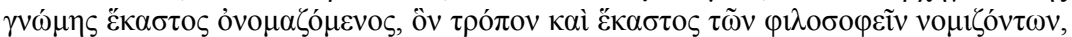

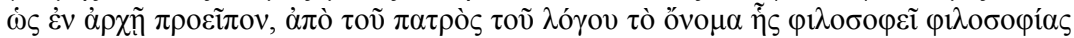

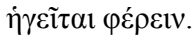

71 Justin seems to understand Christianity as a recovery of "original" philosophy, in much the same way that contemporary philosophers, in particular Stoics and Platonists, considered it the task of philosophy to recover and return to an uncorrupted, ancient wisdom. See Michael Frede, "Celsus' Attack on the Christians," in Philosophia Togata II: Plato and Aristotle at Rome, ed. Jonathan Barnes and Miriam Griffin (Oxford: Oxford University Press, 1997), 229-30; Eshleman, The Social World of Intellectuals in the Roman Empire, 193, and especially George R. Boys-Stones, PostHellenistic Philosophy: A Study of Its Development from the Stoics to Origen (Oxford: Oxford University Press, 2001), 3-59 (Stoicism), 99-122 (Platonism). Cf. also Droge, Homer or Moses?, 68-72.

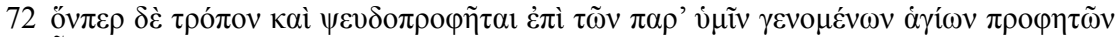

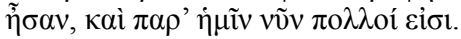

73 It should follow logically from Justin's argument that just as true prophecy has entirely been relocated from the Jews to the Christians, false prophecy (and false teaching) has likewise abandoned the Jews and can now only be found among the Christians. Justin does not, however, draw this conclusion (cf. Dial. 80.4, 82.4). Justin wishes to derive false teaching from the Jews, but resists the idea that false teaching is no longer present among them. The Jews of his day lack prophetic gifts, but they still have false teachers.

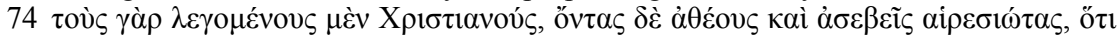

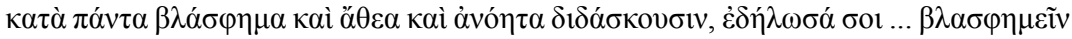

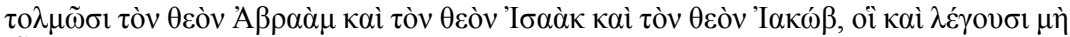

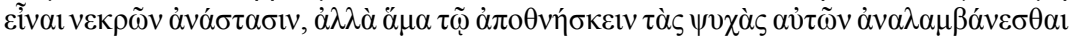

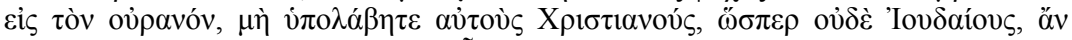

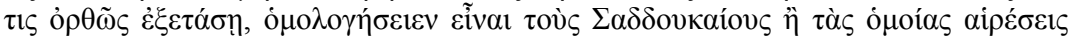

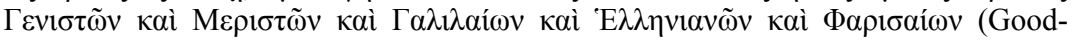

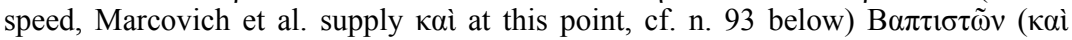

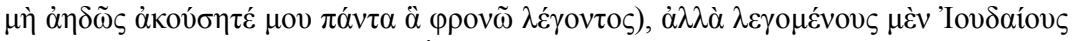

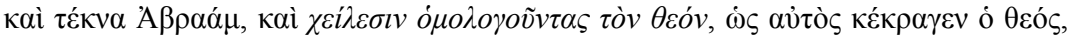

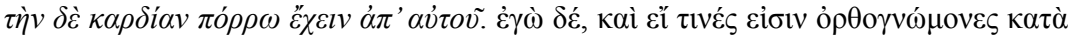

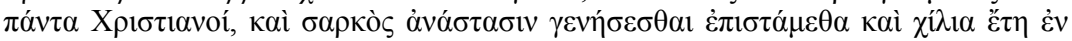

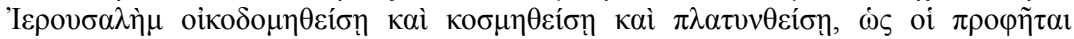

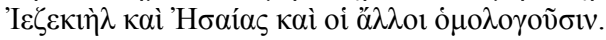

75 For a concise overview of the prominence of the number seven in early Christianity, see Richard I. Pervo, The Making of Paul: Constructions of the Apostle in Early Christianity (Minneapolis, MN: Fortress Press, 2010), 37 ("Excursus: The Number Seven"). More generally on the significance of numbers, Joel Kalvesmaki, The Theology of Arithmetic: Number Symbolism in Platonism and Early Christianity, Hellenic Studies 59 (Washington, DC: Center for Hellenic Studies, 2013).

76 Cf. Boyarin's thesis about the development of heresiology in Jewish and Christian circles as formulated in his Border Lines. For further discussion, see Matthijs den Dulk, “'One Would Not Consider Them Jews': Reassessing Jewish and Christian 'Heresy'," forthcoming in JECS.

77 Hans Joachim Schoeps, Theologie und Geschichte des Judenchristentums (Tübingen: Mohr Siebeck, 1949), 387 n. 3, claimed that the word, like genistae, reflects the Hebrew minim. Daniel Gershenson and Gilles Quispel, "Meristae," VC 12 (1958): 20 , objected that meros is "not an acceptable translation" of min. They instead suggest that meristēs, which is a common enough word in Greek, reflects the participial 
form of Hebrew hlq or Aramaic plg ("to divide") which, according to them, could also mean "dissenter" (Ibid., 25). However, Tjitze Baarda, "Luke 12, 13-14, Tradition and Interpretation," in Christianity, Judaism and Other Greco-Roman Cults: Studies for Morton Smith at Sixty. Part One: New Testament, ed. Jacob Neusner (Leiden: Brill, 1975), $137 \mathrm{n} .147$ considers it doubtful that the Qal participle can have such a meaning. Gershenson and Quispel further argue that a play on the two meanings of $h-l-q / p-l-g$ is reflected in Luke 12:13-14, the only place where the word meristes occurs in the NT, and in GThom 72. For discussion, see April D. DeConick, The Original Gospel of Thomas in Translation (London; New York: T \& T Clark, 2007), 229; Simon J. Gathercole, The Composition of the Gospel of Thomas: Original Language and Influences, SNTSMS 151 (Cambridge; New York: Cambridge University Press, 2012), 87-8. According to Marcel Simon, the meristae were people who divided the godhead (Marcel Simon, Jewish Sects at the Time of Jesus [Philadelphia: Fortress Press, 1967], 93-6). Joan E. Taylor, The Essenes, the Scrolls, and the Dead Sea (Oxford: Oxford University Press, 2012), 181, notes that meristes was "used as a positive epithet of the god Sarapis." Boyarin, Border Lines, 241 n. 22, reads genistae and meristae as "a gloss on the Tosefta's minim weparošim, i.e. as those who separate themselves," which is a reasonable suggestion, but Boyarin refrains from clarifying how or why Justin (or his source) rendered it as meristēs, which has an active ("to divide"), not a reflexive sense. Boyarin also does not address why Justin would have included two different renderings of $p$-r-sh (meristae and Pharisees) in his list. Many proposals boil down to reading meristae as "schismatics" or some such. Apart from the Pharisees, however, who are already included in Justin's list, I am not aware of any ancient Jewish group whose name could possibly be translated as "the schismatics."

78 Boyarin, Border Lines, 241 n. 22.

79 MS Kaufman A 50 (Budapest), MS 95 (Munich), MS 2596 (Parma), and MS 3173 (Parma).

80 E.g., Taylor, The Essenes, the Scrolls, and the Dead Sea, 181. "Galileans" are also mentioned in a letter from Shimon ben Koseba discovered in Wadi Murabba'at (Mur 43). Some scholars identified them as Christians, but perhaps they are simply Jews who came from the Galilee (so, e.g., Eshel, "The Bar Kochba Revolt, 132-135," 114-15).

81 E.g., Matthew Black, "Patristic Accounts of Jewish Sectarianism," Bulletin of the John Rylands Library 41 (1958-1959): 289; Boyarin, Border Lines, 241 n. 22. Cf. also Origen, Cels. 5.62 which refers to a comment by Celsus about the E $2 \varepsilon v 1 \alpha v o$, who were followers of Helen, the consort of Simon Magus.

82 The conflicts between Hillel and Shammai and their followers are regarded in rabbinic literature as "disputes for the sake of heaven" and it is explicitly said that "both these and these are words of the living God." (b. Eruvin 13b). Boyarin, Border Lines, 61, notes that even when $t$. Sotah 14.9 says that they created "two Torot," from the rabbinic point of view "heresy has not been produced."

83 E.g., Le Boulluec, La notion d'hérésie, 74-5; Harnack, Judentum und Judenchristentum in Justins Dialog.

84 As Marcel Simon notes: "Les deux terminaisons en -1avo et pratiquement interchangeables. La seule différence tient à leur formation: l'une est formée sur un verbe - en l'occurence $\dot{\varepsilon} \lambda \lambda \eta v i \zeta \zeta \varepsilon ı v$ - l'autre sur un nom, généralement un nom propre; Mais sur leur identité de sens il n'y a pas de doute. Les disciples de Marcion, que nous appelons Marcionites, sont appelés par les auteurs ecclésias-

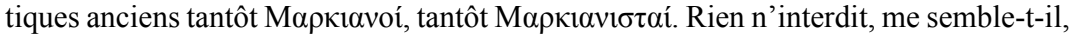
de reconnaître dans Hellenistai-Hellenianoi un couple sémantique du même genre"

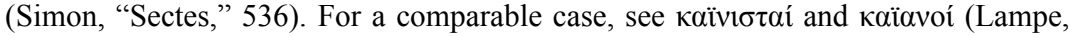
A Patristic Greek Lexicon, 692). The minor difference between Justin and Acts may 
also have to do with the fact that ${ }^{E} \mathrm{E} \lambda \eta \eta v i \sigma \tau \eta \dot{s}$ is an exceedingly rare word in Greek. The noun is not attested before Acts and is rarely used after (see H. Alan Brehm, "The Meaning of 'E $\lambda \lambda \eta v i \sigma \tau \eta$ s in Acts in Light of a Diachronic Analysis of 'E $\lambda \lambda \eta v i ́ \zeta \varepsilon v v$," in Discourse Analysis and Other Topics in Biblical Greek, ed. Stanley E. Porter and Donald A. Carson, JSNT Supplement Series 113 [Sheffield: Sheffield Academic Press, 1995], 180-99). It is not surprising therefore, that there is considerable textual variation on this point in Acts 9:29 and 11:20. The evidence for the reading "E ${ }^{\prime} \lambda \eta v \alpha \varsigma$ in 11:20 is particularly strong and critics are accordingly divided on the oldest reading. See Michael Zugmann, "Hellenisten” in der Apostelgeschichte, WUNT 2.264 (Tübingen: Mohr Siebeck, 2009), 5-7 for discussion. Justin's use of the form with the - avos suffix may, moreover, be related to the fact that this was his preferred way of referring to heresies (cf. Dial. 35). Possibly Justin sought to stress the parallelism between Jewish and Christian heresies by including a Jewish group with an -1avo $\varsigma$ suffix.

85 This interpretation, accepted by many contemporary scholars (see Zugmann, "Hellenisten" in der Apostelgeschichte, 2-3) is based on 1) the fact that the confrontation between Paul and the Hellenists takes place in Jerusalem, which according to Acts 8:1 had been abandoned by the Christians; 2 ) the murderous designs of the Hellenists against Paul; and 3) the contrast that the author of Acts draws between the hellenistai and "the brothers" (oi $\alpha \delta \varepsilon \lambda$ poí [Acts 9:30]).

86 So A. Lukyn Williams, Justin Martyr, the Dialogue with Trypho (London; New York: S.P.C.K.; Macmillan, 1930), 170 n. 4; Boyarin, Border Lines, 241-2 n. 22.

87 Cf. also the sect of followers of John mentioned in Ps.-Clem. Rec. 1.54, 60.

88 Black, "Patristic Accounts of Jewish Sectarianism," 290, believed that "the ancient Sadducees almost certainly disappeared from the scene with the Temple" and therefore proposed that Justin's Sadducees were in fact Zadokites, i.e. Essenes (accepted by Leslie W. Barnard, "The Old Testament and Judaism in the Writings of Justin Martyr," VT 14 [1964]: 51; Philippe Bobichon, “Autorités religieuses juives et 'sectes' juives dans l'œuvre de Justin Martyr," Revue des Études Augustiniennes 48 [2002]: 15; Giorgio Otranto, Esegesi biblica e storia in Giustino: (dial. 63-64) [Bari: Istituto di letteratura cristiana antica-Università, 1979], 208). On the fate of the Sadducees, see Martin Goodman, "Sadducees and Essenes After 70 CE," in Crossing the Boundaries: Essays in Biblical Interpretation in Honour of Michael D. Goulder, ed. Stanley E. Porter, Paul Joyce, and David E. Orton, Biblical Interpretation 8 (Leiden: Brill, 1994), 348-56. Against Black's interpretation speaks the likelihood that Justin put the Sadducees at the top of the list because he was discussing denial of the resurrection of the dead in the immediate context. The rejection of this idea by the Sadducees is well attested (Mt 22:23, Mk 22:18, Lk 20:27, Acts 23:8, cf. Josephus, Ant. 18.16), while various scrolls found in Qumran suggest that the Essenes did not share that view (see, e.g., George W.E. Nickelsburg, Resurrection, Immortality, and Eternal Life in Intertestamental Judaism and Early Christianity [Cambridge, MA: Harvard University Press, 2006], 12).

89 Leslie W. Barnard, Justin Martyr: His Life and Thought (Cambridge: Cambridge University Press, 1967), 50. Similarly Williams, Justin Martyr, the Dialogue with Trypho, 171 n. 4: "it is uncomprehensible (sic) how J. can have denied the orthodoxy of the (Pharisees)...."

90 Shaye J.D. Cohen, "The Significance of Yavneh: Pharisees, Rabbis, and the End of Jewish Sectarianism," HUCA 55 (1984): 29. Cited by Boyarin, Border Lines, 42.

91 Boyarin, Border Lines, 42.

92 Ibid., 69-70.

93 Other explanations of Justin's inclusion of the Pharisees and Sadducees include Sigal's argument that Justin did not use the word hairesis in the sense of "heresy," but simply with the meaning "sect," so that their inclusion is "not an issue" (Phillip Sigal, "An 
Inquiry into Aspects of Judaism in Justin's Dialogue with Trypho," Abr-Nahrain 18 [1979]: 84). Given the context ("one would not consider [them] to be Jews ... but socalled Jews") this reading is implausible. The same is true of Simon's suggestion that the Pharisees are included because they are heretics or at least non-orthodox from the Christian point of view. Justin, however, is clearly distinguishing between Christian and Jewish haireseis in this passage. Another solution is to read "Baptist Pharisees," combining the sixth and the seventh groups on the list. There is an anacoluthon in the manuscripts ( $k a i$ is supplied in many editions), so this reading is not impossible. It is also quite possible, however, that a scribe alarmed by the presence of the Pharisees on this list removed an original kai. It should be recalled here that our manuscript is in a poor state and textual emendations are often necessary to restore an intelligible reading of the text. Black accepts the reading "Baptist Pharisees" and argues that it explains the parenthetical "do not be offended when you hear me say all that I think." In Black's view, Justin "clearly felt it necessary to say this in view of his mention of Pharisees, even heretical Pharisees, in such disrespectable company as the other Minim listed" (Black, "Patristic Accounts of Jewish Sectarianism," 289). The "Baptist Pharisees" reading was already mentioned by Harnack, but he rejected it. Harnack preferred to explain "the Pharisees" as a later addition, the work of a scribe who wanted to create a list of seven heresies (Harnack, Judentum und Judenchristentum in Justins Dialog, 57).

94 Boyarin, Border Lines, 242 n. 22.

95 Cf. Shaye J.D. Cohen, "A Virgin Defiled: Some Rabbinic and Christian Views on the Origins of Heresy," USQR 36 (1980): 3: "It made no difference to the rabbis whether their opponents were Gentile Christians, Jewish Christians, Gnostics of any variety, pagans, or dissident Jews; all of them, to the exasperation of later scholars, were called minim." More recently, Jonathan Klawans, "Heresy without Orthodoxy: Josephus and the Rabbis on the Dangers of Illegitimate Jewish Beliefs," JJMJS 1 (2014): 121, has offered a similar assessment. David M. Grossberg, Heresy and the Formation of the Rabbinic Community, TSAJ 168 (Tübingen: Mohr Siebeck, 2017), 57-72, has argued that in a pre-rabbinic stage, minim referred to a specific sectarian group that did not survive the upheavals of 70 C.E.

96 Geoffrey Smith refers to $m$. Sanh. 10.1 as a passage that "might generically be characterized" as a "heresy catalogue" and lists it as an example (the only example, in fact) in support of his claim that "one may point to lists of minim in rabbinic texts as examples of Jewish heresy catalogues" (Smith, Guilt by Association, 1-2, 103). However, the word $\min$ does not occur here and the passage only lists certain teachings that are beyond the pale; it does not list groups, as in Justin. It is also uncertain that the rhetoric of $m$. Sanh. 10.1 is best understood as heresiological because 1) insiders are mentioned alongside outsiders [cf. 10.3ff.]; and 2) the exclusion from the community is postponed to the "world to come." The latter is true also for Sifre Deut. 329, which targets three different views with which the rabbis disagree: 1) there is no power in heaven; 2) there are two powers in heaven; 3 ) there is no power in heaven "to kill or to revive, none to do evil or to make good" (ed. Finkelstein, 379). For discussion of this passage, see Adiel Schremer, "Midrash, Theology, and History: Two Powers in Heaven Revisited" JSJ 39 (2008): 234-9, and the literature cited there. The first two opinions are also attacked in tandem in Sifre Zuta Shalah 15.30. Perhaps a slightly better candidate for the label "heresy catalogue" is $y$. Sanh. 10.5, where we read, "Israel did not go into exile until it had turned into twenty-four parties of minim." While this passage indicates that there are different kinds of minim, they are not individually listed. Hence even this passage has little in common with the heresy catalogues found in Justin, Irenaeus, Tertullian, Hippolytus and other early Christian authors. Cf. Adiel Schremer, Brothers Estranged: Heresy, Christianity, and Jewish Identity 
in Late Antiquity (Oxford; New York: Oxford University Press, 2010), 71, 186 n. 15: "no rabbinic parallel to any of the patristic Adversus Haereses works is known to have ever existed." In Avot de Rabbi-Nathan Version A, 5.3-4 (cf. version B, 10.3), we read "They arose and separated themselves from the Torah, and two schisms were created: the Sadducees and the Baithuseans. The Sadducees in the name of Sadoq, and the Baithuseans, in the name of Baithus." This is perhaps the closest rabbinic literature comes to a "heresy catalogue," but it appears in a text that in its present form is postTalmudic. See also den Dulk, "One Would Not Consider Them Jews."

97 The only other source that might provide some evidence of such a use of the word hairesis in Jewish circles is Acts 24:14 (some scholars have made much of this: e.g.,

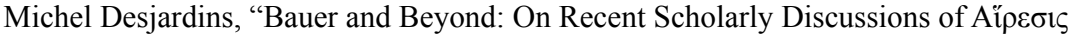
in the Early Christian Era," Second Century 8 [1991]: 76-7), but even in Acts 24:14 it is not clear that hairesis is pejorative in and of itself. Paul also uses hairesis in a negative sense (esp. Gal 5:20, cf. 1 Cor 11:19), which could reflect wider Jewish use of the term, but his usage is still very different from that of early Christian heresiologists. For further discussion, see den Dulk, "One Would Not Consider Them Jews."

98 E.g. Alex Heinrich Goldfahn, "Justinus Martyr und die Agada," Monatsschrift für Geschichte und Wissenschaft des Judentums 22 (1873): 49-60, 104-15, 145-53, 194202, 257-69; Willis A. Shotwell, The Biblical Exegesis of Justin Martyr (London: S.P.C.K., 1965), who relies heavily on Goldfahn's work.

99 Rokeah, Justin Martyr and the Jews, 130; cf. Marc G. Hirshman, A Rivalry of Genius: Jewish and Christian Biblical Interpretation in Late Antiquity, SUNY Series in Judaica (Albany: State University of New York Press, 1996), 65: "his knowledge of Jewish exegesis in general and rabbinic exegesis in particular is, on the whole, unimpressive"; Robert S. MacLennan, Early Christian Texts on Jews and Judaism, Brown Judaic Studies 194 (Atlanta, GA: Scholars Press, 1990), 64: "Rabbinic Judaism, then, may have been known to him, if at all, through discussions and hearsay." See also Mach, "Justin Martyr's Dialogus Cum Tryphone Iudaeo and the Development of Christian Anti-Judaism," 30 n. 10.

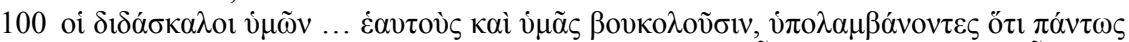

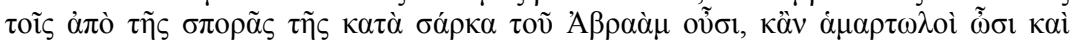

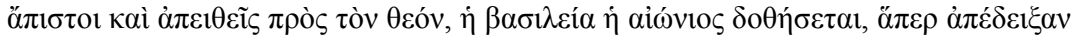

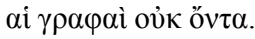

101 Cf. the appearance of "Herodians" and "Scribes" in later patristic lists of Jewish "heresies," which, as Elias Bi(c)kerman has shown, are almost certainly unhistorical fictions invented on the basis of the accounts in the canonical Gospels (Elias Bikerman, "Les Hérodiens," Revue Biblique 47 [1938]: 184-7).

102 On Justin's knowledge of Acts, see the appendix to this study.

103 Taylor, The Essenes, the Scrolls, and the Dead Sea, 181, notes: "Strikingly ... the Essenes are not found"; Simon, "Les sectes juives," 528: "Mais il est curieux que l'une de ces trois ramifications du judaïsme classique soit absente du catalogue de Justin, savoir les Esséniens." Similarly, Black, "Patristic Accounts of Jewish Sectarianism," 228; Bobichon, “Autorités religieuses juives et 'sectes' juives dans l'œuvre de Justin Martyr," 14.

104 The Christians are also called a hairesis in Acts $(24: 5,14 ; 28: 22)$ and this left an imprint on other passages in the Dialogue, as I argue in the appendix.

105 Border Lines, 43. Yet Boyarin feels that Le Boulluec's comment that "La représentation hérésiologique a cependant besoin de déformer la conception juive des divers courants religieux pour atteindre son efficacité entière" (Le Boulluec, La notion d'hérésie, 71) goes too far: "In my view this is less of a deformation than Le Boulluec would have it" (242 n. 23). I would argue in light of the argument advanced above that Justin drew on Acts that, if anything, Le Boulluec does not go quite far enough. 
106 One could read Hegesippus's list of seven Jewish heresies (or at least Eusebius's version of it [Hist. eccl. 4.22.7]) as an improved, more verisimilitudinous version of Justin's list:

\begin{tabular}{ll}
\hline Justin & Hegesippus \\
\hline Sadducees & Sadducees \\
Genistae & - \\
Meristae & - \\
Galileans & Galileans \\
Hellenians & - \\
Pharisees & Pharisees \\
Baptists & Hemerobaptists \\
& Essenes \\
& Masbothei \\
& Samaritans \\
\hline
\end{tabular}

A relation between the two lists is strongly suggested by the presence of the Pharisees, Sadducees, Galileans and a Baptist group in both of these lists (pace Adolf von Harnack, Zur Quellenkritik der Geschichte des Gnosticismus [Leipzig: E. Bidder, 1873], 38-9, the "heresies" on the two lists are clearly not "ganz andere.") Hegesippus's catalogue is, however, more historically plausible. It leaves out the Genistae, Meristae and Hellenians, groups that, as noted above, are either difficult to identify or do not refer to a single "heresy." The groups that are added by Hegesippus are more suitable to a list of Jewish "heresies." The Essenes and the Samaritans are well attested and were generally understood as separate from the Jewish mainstream. In addition, Hegesippus's list has "Hemerobaptists," where Justin's has "Baptists." In contrast to the latter, the former can easily be connected to the "morning baptizers" mentioned in the Tosefta. I suggest, then, that Hegesippus's list is best understood as an improved, more realistic version of Justin's. In his effort to reach a seven-item list, Justin relied on Acts and included a number of less-than-suitable names. Hegesippus saw the symbolic value of a list of seven names, but replaced some of the most implausible groups with more credible alternatives.

The only truly puzzling item on Hegesippus's list is the Masbothei, who are otherwise unknown. Birger A. Pearson, Ancient Gnosticism: Traditions and Literature (Minneapolis, MN: Fortress Press, 2007), 329 notes that they may have been early Mandaeans in light of the fact that the Mandaic word for baptism is mașbuta. Simon, Jewish Sects at the Time of Jesus, 88 claims that "the term 'Masbothei' is almost certainly the Greek rendering of an Aramaic doublet for the Baptists, and undoubtedly designates the same sect." Hegesippus seems in any case to have been confused about the Masbothei, because he includes them both among the Jewish haireseis (Hist. eccl. 4.22.7) and among the Christian ones that derived from these Jewish groups (Hist. eccl. 4.22.5). Did Hegesippus think that there were both Jewish and Christian branches of the Masbothei?

107 Perhaps Justin's enigmatic interjection in Trypho's direction ("do not be offended when you hear me say all that I think" [Dial. 80.4]) is to be understood in this light. Given the cultural imperative of unity, suggesting that a tradition was suffering deep internal division constituted a painful allegation and Justin rightly imagined that a Jewish interlocutor would be offended by his claims about the existence of many Jewish splinter groups. 
108 The knowledge that Justin has about contemporary Judaism appears to be precisely the sort that one might obtain in the give and take of debate (which the Dialogue indicates Justin had extensively engaged in [50.1]). For instance, Justin's awareness of textual differences between the LXX and the Hebrew text would have come to light soon enough if Justin would make a claim based on a certain passage that his Jewish interlocutor rejected as spurious. Justin's (limited) familiarity with Jewish exegetical traditions can be explained along the same lines. It is highly doubtful, however, that Justin would be informed accurately about Jewish "heresies" in this manner. Why would his Jewish interlocutor volunteer such information? At such points Justin may well have turned to Christian sources to inform his claims.

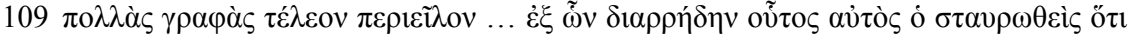

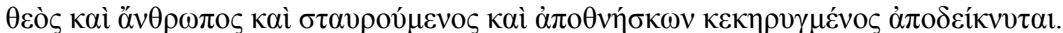

110 Cf. also Justin's insistence that that Jews alone had to be circumcised (Dial. 19.5) even though he was evidently aware that other peoples practiced circumcision as well (28.4). Another point at which he simply seems misinformed is when he elaborates on the origins of the word satanas (Dial. 103.5; cf. Rokeah, Justin Martyr and the Jews, 21).

111 On the syntax of this phrase, see Bobichon, Justin Martyr, Dialogue avec Tryphon, 2:

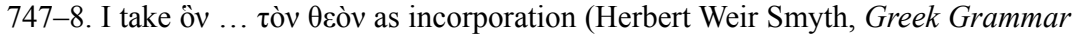
[Cambridge, MA: Harvard University Press, 1956], §2536; Albert Rijksbaron, The Syntax and Semantics of the Verb in Classical Greek [Chicago: University of Chicago Press, 2006], §29.3.v). Cf. David Runia's translation: "The same thing, dear friends, the Logos of God said also through Moses, when he recounted to us that the God whom he made manifest spoke in exactly the same vein at the creation of man ..." (David T. Runia, “'Where, Tell Me, Is the Jew ...?': Basil, Philo and Isidore of Pelusium," VC 46 [1992]: 178).

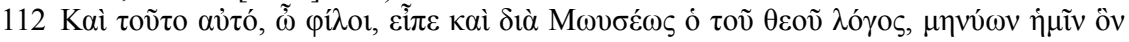

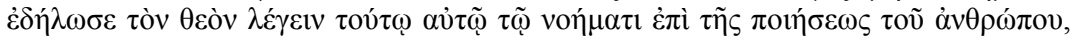

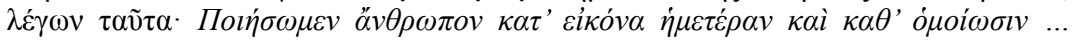

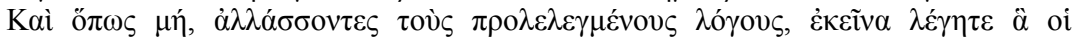

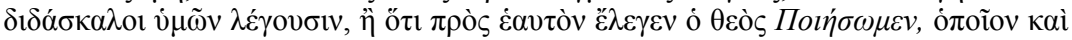

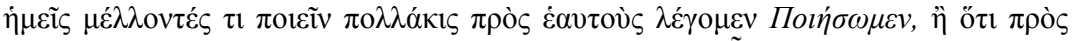

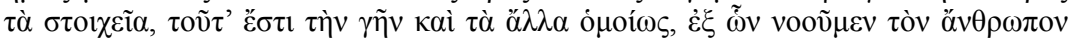

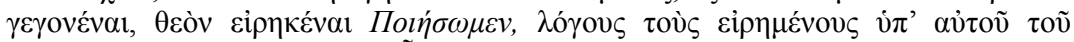

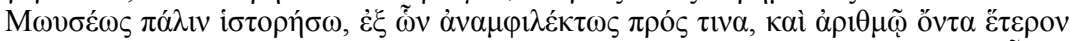

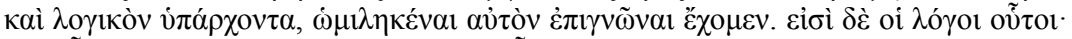

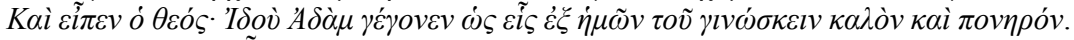

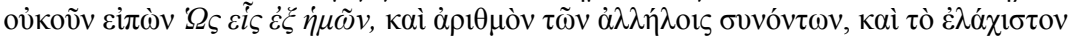

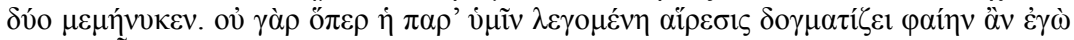

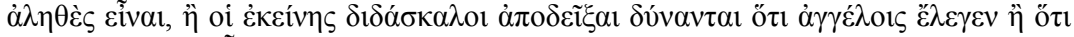

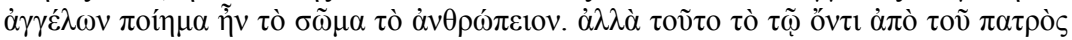

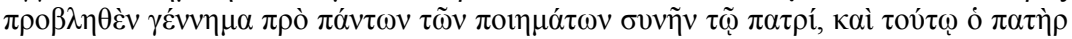

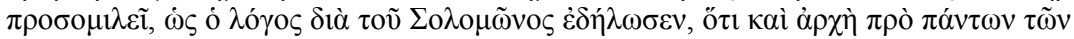

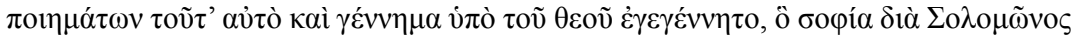
$\kappa \alpha \lambda \varepsilon \tilde{\tau} \tau \alpha 1$.

113 For previous discussion of this passage see, e.g., Marcel Simon, "From Greek Hairesis to Christian Heresy," in Early Christian Literature and the Classical Intellectual Tradition: In Honorem Robert M. Grant, ed. William R. Schoedel and Robert L. Wilken (Paris: Éditions Beauchesne, 1979), 106; Le Boulluec, La notion d'hérésie, 77-8; Menahem Kister, "Some Early Jewish and Christian Exegetical Problems and the Dynamics of Monotheism," JSJ 37 (2006): 569; Bobichon, Justin Martyr, Dialogue avec Tryphon, 2: 948-52; Barnard, "The Old Testament and Judaism in the Writings of Justin Martyr," 405; Michael J. Choi, "What Is Christian Orthodoxy According to 
Justin's Dialogue?," SJT 63 (2010): 404-6; Leszek Misiarczyk, Il midrash nel Dialogo con Trifone di Giustino martire (Płock: Płocki instytut wydawniczy, 1999), 146-65.

114 Boyarin, Border Lines, 41, notes that the "marginal, even heretical figure, Papos" read the phrase "one of us" (Gen 3:22) as "one of the ministering angels" according to the Mekhilta de-Rabbi Ishmael (Tractate, Beshallah, 7 [Lauterbach 1: 248]). For Boyarin, this "provides evidence - albeit somewhat ex post facto - for the authenticity of Justin's information and its richness of detail." He does not, however, consider the many other sources from which Justin may have derived this tradition and, more importantly, glosses over the second, more distinctive view that Justin ascribes to the Jewish "heresy" (the creation of the human body by angels), a notion that is not ascribed to Papos. The analysis presented here will lead to rather different conclusions about the "authenticity of Justin's information and its richness of detail."

115 Cf. Jarl Fossum, "Gen. 1,26 and 2,7 in Judaism, Samaritanism, and Gnosticism," JSJ 16 (1985): 203-8, esp. 205: "To Philo ... God's co-creators are ... 'powers', which is a synonym of 'angels'. That Philo assumes this equation is brought out clearly in a passage from De confusione linguarum, where the idea that God is not the immediate agent of punishing and the idea that he is not the creator of evil again are associated. God's auxiliaries are here called 'innumerable powers being helpers and saviours of all created existences' and 'unbodied souls, commonly called "angels" in the inspired writings, who attend to these heavenly powers.'" The reference is to Conf. 174, note also Conf. 181. With Robin McL. Wilson, "The Early History of the Exegesis of Gen 1:26," in Studia Patristica I (Berlin: Akademie-Verlag, 1957), 433-7, it should be noted, however, that "Of the four passages in which the question is discussed, one only (De conf. ling. 168ff) mentions angels in the context as attendant beings. In none is it explicitly stated that it was to the angels that the words were spoken." David T. Runia, Philo of Alexandria and the Timaeus of Plato, Philosophia Antiqua 44 (Leiden: Brill, 1986), 16, argues that "Philo deliberately avoids making a concrete identification of God's helpers, thus preserving to a certain extent the reticence of the Biblical text" (emphasis added). In a later article (Runia, "Where, Tell Me, Is the Jew...?," 177) he adds that "this does not mean, of course, that it could not happen that subsequent readers, who were acquainted with other exegetical traditions, did interpret Philo's words as referring to angels."

116 Gen. Rab. 8.4 (R. Hanina), 8.5 (R. Simon and R. Huna the Elder).

117 b. Sanh. 38b, Num. Rab. 19.3, Eccl. Rab. 7.23.1. See also Tg. Ps-Jonathan on Gen 1:26. Cf. Kister, "Some Early Jewish and Christian Exegetical Problems," 570: "This view, prevalent in midrashic literature, is parallel to what Justin called the heretical opinion." There are, of course, also plenty of Jewish texts (rabbinic and non-rabbinic) that stress God's sole responsibility for creation (e.g., 4 Ezra 3:4; Josephus, C. Ap. 2.192; Gen. Rab. 8.8).

118 Cf. also GThom 50 (with DeConick's commentary in April D. DeConick, Seek to See Him: Ascent and Vision Mysticism in the Gospel of Thomas, VC Supplements 33 [Leiden; New York: Brill, 1996], 68-70); GJudas 52.14-15: "Then Saklas said to his angels, 'Let us create a human being after the likeness and after the image.' "Irenaeus offers a rebuttal of such ideas in A.H. 4.20.1: "Scripture said: 'And God formed man, taking dust of the earth, and breathed into his face the breath of life.' Therefore, angels did not make us, nor did they form us...."

119 Tertullian, Adversus Praxean, 12 ascribes this view to the Jews in general (ut Iudaei interpretantur). (Noted by Runia, "Where, Tell Me, Is the Jew...?," 179). Similarly, Basil, Hexaemeron, 9.6 (see Ibid., 173).

120 For discussion of the anthropogony of this text, see Roel van den Broek, "The Creation of Adam's Psychic Body in the Apocryphon of John," in Studies in Gnosticism and Hellenistic Religions: Presented to Gilles Quispel on the Occasion of His 65th Birthday, ed. Roel van den Broek and Maarten Jozef Vermaseren (Leiden: Brill, 1981), 
38-57; Gerard P. Luttikhuizen, "The Creation of Man and Woman in the Secret Book of John," in The Creation of Man and Woman: Interpretations of the Biblical Narratives in Jewish and Christian Traditions, ed. Gerard P. Luttikhuizen, TBN 3 (Leiden; Boston: Brill, 2000), 140-55.

121 Cf. also Valentinus's, "Fragment 1" (apud Clement, Strom., 2.36.2-4). For discussion, see Einar Thomassen, The Spiritual Seed: The Church of the "Valentinians," vol. 60, Nag Hammadi and Manichaean Studies (Leiden; Boston: Brill, 2006), 430-3; Dunderberg, Beyond Gnosticism, 46-9; Markschies, Valentinus Gnosticus?, 11-53. This teaching is not quite the same as the tradition found in rabbinic literature that "man was created in the image of the angels" (Ex. Rab 30.16, cf. b. Sanh. 38b [where God asks the ministering angels "Is it your wish that we create man in our image?"], Gen. Rab. 8.11, Num. Rab. 16.24). This tradition does not claim that the angels were the exclusive creators (only that the creature was made in their image), and more importantly, it does not mention the human body, but simply the human being (adam). Philo does appear to distinguish between the creation of the body by "the Craftsman" and the creation of the soul by the "Father and Ruler of All": "For the body came about when the Craftsman took soil and formed a human shape out of it, but the soul derived from no (created) matter at all but came from the Father and Ruler of All"

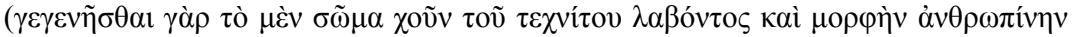

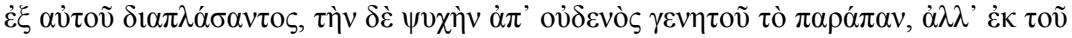

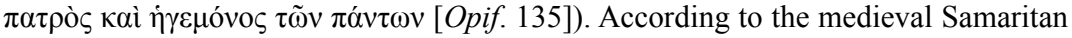
catechism known as the Malef, a single angel ("the Angel of YHWH") was responsible for the material body. See Fossum, "Gen. 1,26 and 2,7 in Judaism, Samaritanism, and Gnosticism," 221, who argues that this tradition goes back to at least the fourth century (pp. 221-7).

122 The absence of pronouns in this reference to Gen 1:26 is striking and something that Epiphanius would later address directly (as noted by Kister, "Some Early Jewish and Christian Exegetical Problems," 568): "The charlatan [Satornilus] dramatically represents the angels as saying, 'Let us make man in an image and after a likeness.' To give his imposture plausibility he [Satornilus] falsified the word 'our,' spoken in Genesis by the holy God, < but > retained 'in an image' - as though other persons were making an image, if you please, and $<$ were showing $>$ that it was someone else's image $<$ by $>$ saying, 'Let us make man in an image and after a likeness." " (Panarion 23.4-7; Tr.: Frank Williams, The Panarion of Epiphanius of Salamis, NHS 35 [Leiden: Brill, 1987], 1.64). Most witnesses to the LXX text of Gen 1:26 have only one personal pronoun ( $\dot{\eta} \mu \varepsilon \tau \varepsilon \dot{\varepsilon} \rho \alpha$ ),

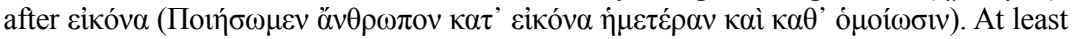

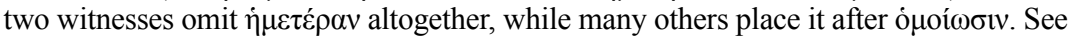
John William Wevers, Text History of the Greek Genesis (Göttingen: Vandenhoeck \& Ruprecht, 1974), ad loc. A number of rabbinic passages contend that Greek translations read, "Let me make man in image and likeness" (Mek. R. Yish. Pisha 14 [to Ex. 12:40; ed. Horovitz-Rabin, 50; Lauterbach 1:111]; y. Meg. 1:11, 71d; b. Meg. 9a).

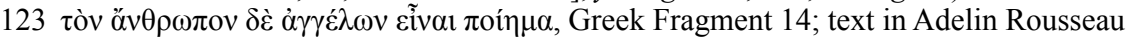
and Louis Doutreleau, Irenée de Lyon: Contre les hérésies (Livre I, Tome II), SC 264 (Paris: Éditions du Cerf, 1979).

124 Fossum, "Gen. 1,26 and 2,7 in Judaism, Samaritanism, and Gnosticism," 228, concludes in light of the similar ideas found in Samaritan, Rabbinic and Philonic material, that "[t]here is no good reason to doubt Justin's words that there also was a Jewish teaching to the effect that God not only spoke to the angels, but also that the angels created the body of man." In his view, Saturninus has "preserved the idea that the angels made the body of man, while God gave him the spirit" (234, emphasis added), but he does not connect Saturninus's teaching with Justin's "Jewish heresy." 
125 One may compare Dial. 128.2-3, where Justin again seems to be attacking an idea that is at the very least also a Christian "heresy" (see Boyarin, Border Lines, 38-9) but without identifying it as such, hence at least tacitly suggesting that this is an idea (also) entertained by the Jews with whom he is conversing.

126 Le Boulluec thought that Justin sought to imitate the ways in which the Pharisaic party established its hegemony at Yavneh. However, as Boyarin has pointed out, this is based on an outdated and naïve reading of rabbinic literature that takes at face value historical pronouncements in rabbinic texts, even if these claims appear for the first time in much later literature (Boyarin, Border Lines, 76). In recent decades many scholars have come to the plausible conclusion that the council of Yavneh is substantially a later projection. This renders some of the parallels that Le Boulluec and others detect between second-century Christianity and Judaism problematic.

127 Eduard Iricinschi and Holger M. Zellentin, "Making Selves and Marking Others: Identity and Late Antique Heresiologies," in Heresy and Identity in Late Antiquity, ed. Eduard Iricinschi and Holger M. Zellentin, TSAJ 119 (Tübingen: Mohr Siebeck, 2008), 9 n. 32.

128 Cf. notes 96 and 97 above. In a recent article, Jonathan Klawans has made an argument for Jewish influence on Christian heresiology from a different angle. According to Klawans, the roots of heresiological discourse may be located in Josephus' description of the "Fourth Philosophy" in Ant. 18.23-25, where "Josephus appears to be following - or, as far as we can tell, establishing - the heresiology rule-book. Josephus is constructing an identifiable group, characterized by distinct, erroneous theological positions; he is providing a label for it, identifying a 'Johnny come lately' putative founder, and carefully denying the group legitimate roots in scripture or tradition. Indeed, anticipating Epiphanius and Irenaeus, Josephus depicts the fourth philosophy as a contagious illness of folly. And while the group is not deemed 'satanic' as some Christian heretics will be, Josephus nevertheless depicts the Fourth Philosophy as having brought the nation to ruin, which is about as demoniacal as things can get in Josephus" (Klawans, "Heresy without Orthodoxy: Josephus and the Rabbis on the Dangers of Illegitimate Jewish Beliefs," 113-14). The parallels are impressive, but it should be noted that while it is true that Josephus disapproves of the Fourth Philosophy, there is no clear sense of removal or exclusion from the community. To the contrary, by referring to them as the Fourth Philosophy, Josephus implies that they belong to the people of Israel alongside the other three "philosophies" that he discusses (Pharisees, Sadducees, Essenes). Josephus' discussion of the Fourth Philosophy is, then, perhaps ultimately not all that different from polemic against rival haireseis among philosophers and medical theorists.

129 Lampe, From Paul to Valentinus, 385. Similarly, Einar Thomassen, "Orthodoxy and Heresy in Second-Century Rome," HTR 97 (2004): 241-56.

130 Lampe, From Paul to Valentinus, 392-3. Thomassen, "Orthodoxy and Heresy," 242: "what is most interesting about this split is that Marcion himself caused it. He resigned from the church in protest; he was not excluded from that body"; 243: "Marcion's situation is quite the opposite of that of an expelled heretic, for it is he who refused to accept his opponents as true Christians."

131 Lampe, From Paul to Valentinus, 394.

132 Gerd Lüdemann, "Zur Geschichte des ältesten Christentums in Rom. I. Valentin und Marcion. II. Ptolemäus und Justin,” ZNW 70 (1979): 112-14; Lampe, From Paul to Valentinus, 389-91. Florinus and Marcus may have been partial exceptions; see Ismo Dunderberg, "The School of Valentinus," in A Companion to Second-Century Christian "Heretics," ed. Antti Marjanen and Petri Luomanen, VC Supplements 76 (Leiden; Boston: Brill, 2005), 95-6. 
133 Walter Bauer, Orthodoxy and Heresy in Earliest Christianity, trans., Robert A. Kraft and Gerhard Krodel (Philadelphia: Fortress Press, 1971 [1934]), 234. Bauer does allow for some exceptions: 1 Cor 5:1-5 (p. 235) and Galatians (p. 236).

134 Hans Dieter Betz, "Orthodoxy and Heresy in Primitive Christianity," Interpretation 19 (1965): 307-8; cf. also Christoph Markschies, Kaiserzeitliche christliche Theologie und ihre Institutionen: Prolegomena zu einer Geschichte der antiken christlichen Theologie (Tübingen: Mohr Siebeck, 2007), 352.

135 Robert M. Royalty, The Origin of Heresy: A History of Discourse in Second Temple Judaism and Early Christianity, Routledge Studies in Religion 18 (New York: Routledge, 2013), 64-88.

136 Ibid., esp. 89-146. See also Lieu, "From Us but Not of Us?"

137 On homonoia in Paul, see Margaret M. Mitchell, Paul and the Rhetoric of Reconciliation: An Exegetical Investigation of the Language and Composition of 1 Corinthians (Tübingen: Mohr Siebeck, 1991). See also Dale B. Martin, The Corinthian Body (New Haven: Yale University Press, 1995); Laurence L. Welborn, "On the Discord in Corinth: 1 Corinthians 1-4 and Ancient Politics," JBL 106 (1987): 85-111. For Ignatius, see Harry O. Maier, "The Politics and Rhetoric of Discord and Concord in Paul and Ignatius," in Trajectories through the New Testament and the Apostolic Fathers, ed. Andrew Gregory and Christopher Tuckett (Oxford: Oxford University Press, 2007), 307-24; John-Paul Lotz, Ignatius and Concord: The Background and Use of the Language of Concord in the Letters of Ignatius of Antioch, Patristic Studies 8 (New York: Peter Lang, 2007); Brent, Ignatius of Antioch and the Second Sophistic; On First Clement, see Odd Magne Bakke, "Concord and Peace": A Rhetorical Analysis of the First Letter of Clement with an Emphasis on the Language of Unity and Sedition, WUNT 2.143 (Tübingen: Mohr Siebeck, 2001).

138 See pp. 80-81.

139 That Justin is more interested in convincing fellow Christians of the necessity of heresiology than in persuading Jews that early Christian divisiveness was not a problem is suggested by the fact that his artful arguments in Dial. 62 and 80 would not have been convincing to a well-informed Jewish audience but presumably would have carried force with Christian readers, most of whom likely knew less about contemporary Judaism than Justin himself. Perhaps a Jew like Trypho, who may not have been particularly well informed about Jewish currents elsewhere in the world, would have accepted Justin's claims about Jewish "heresies," but this would hardly be a convincing line of argument to a Jewish audience more generally. The case is comparable to that of Justin's accusations that the Jewish leaders tampered with the Scriptures, a theory that Trypho does not dismiss (Dial. 73.5) and would likely have been readily accepted by Christian readers but would probably not have been persuasive to a Jewish audience at large. 


\section{CONCLUSION}

Justin's Dialogue with Trypho sits at the crossroads of various discursive developments central to the formation of early Christianity. At the time of its composition in the mid-second century $\mathrm{CE}$, many of the constitutive parts of what would eventually become "orthodox" Christianity were still being negotiated and the boundaries between Christianity and Judaism as well as between various rival "Christianities" remained in flux and permeable. I have argued that taking this historical setting seriously means that we must move beyond the common scholarly construal of the Dialogue in terms of "Christianity vs. Judaism." Justin is arguing for a particular interpretation and positioning of Christianity vis-à-vis Judaism, and he is doing so in constant negotiation with rival Christian theologies. He develops his particular account of Christianity's relation to Jewish as well as Greco-Roman philosophical traditions in response to, and with a constant eye on, Christian opponents who construed these relations very differently. Justin's concern with such "other" Christians, most notably those who adhered to the notion that the Jewish God was an inferior Demiurge, has deeply impacted the Dialogue and must be taken into account in the interpretation of individual passages as well as of the text as a whole. Since the Dialogue is among our most important sources for such important questions as early Jewish-Christian relations and the purported "parting of the ways," the forging of Christian identity via the invention and implementation of the orthodoxy-heresy binary, and the position of Christ-groups vis-à-vis the Greco-Roman philosophical tradition, the novel interpretation of the Dialogue advanced here has implications that go beyond the Dialogue itself.

The first chapter established the plausibility of this study's central thesis by arguing that Justin had been deeply committed to combatting demiurgical Christians prior to composing the Dialogue. They were central to his argument in the First Apology, because they furnished him with the rhetorical opportunity to try to exculpate "true" Christians from the charges of immorality and criminality. Justin sought to shift the blame to those who seemed to be Christian but in his view really were not. Since these "heretics" were the ones who deserved blame, they were also the ones who ought to be prosecuted (or even persecuted) by the Romans, Justin argued. He developed this line of argument by insinuating that his 
demiurgical opponents were "atheists" because they failed to properly worship the Demiurge, thus deflecting the central accusation brought against Christians in general. Rather than requesting the cessation of hostilities against the Christians tout court, Justin's petition sought Roman toleration of Christians like him, while encouraging Roman opposition to these other Christians. Justin's focus on these demiurgical Christians can be traced back even further to the lost work against the heresies mentioned in $1 \mathrm{Apol}$. 26, which, recent arguments to the contrary notwithstanding, was most likely authored by Justin. There is good reason to think that all of the figures attacked in this document advocated demiurgical forms of Christianity.

Chapter 2 turned to the Dialogue itself and addressed the complicated and contested question of its audience, arguing that there are very good grounds for assuming that the Dialogue was written first and foremost with an internal audience in mind. These grounds include a passage in the Dialogue in which Justin intimates that he expected that this text would be read by other Christians (Dial. 80.3 ), and consideration of the practical realities of ancient book production, presentation, and dissemination. Simply put, Justin must have been aware that the Dialogue would be read, first and foremost, within his own circle. He was genuinely interested in reaching non-Jesus-believing Jews, but he must have realized that this was more likely to happen via mediation by his internal audience rather than by directly addressing such an external audience, which on a practical level would have been extremely difficult since book production and distribution almost always took place within already existing social circles.

Chapter 3 argued that part of the work that the Dialogue was meant to do was to undercut the teachings of Justin's demiurgical opponents. Virtually every topic discussed in the Dialogue was relevant to Justin's debate with the demiurgists, who fundamentally disagreed with him on major points, including his understanding of God, Scripture and ekklesia. Justin's attempts to demonstrate that Jesus was predicted in the Jewish Scriptures, that the New and the Old Testaments do not imply divine inconsistency and that the Christian community is the New Israel are all immediately pertinent to this internal Christian conversation. This is confirmed by the fact that both Tertullian and Irenaeus cover much the same ground in works that are explicitly targeting demiurgical "Christianities" (most notably Tertullian's Adversus Marcionem and Book 4 of Irenaeus's Adversus Haereses). Further contributing to the plausibility of this anti-demiurgical reading of the Dialogue are moments in the text where Justin seems to respond to ideas put forward by his demiurgical rivals rather than to issues immediately pertinent to the conversation with Trypho. For instance, when Trypho inquires why Christians do not observe the Mosaic Law, Justin begins his response by saying "There will never be another God, Trypho, nor has there ever been one ... except the one who made and ordered this universe" (Dial. 11.1). Justin's assurance that he believes in only one God and that this God is the Creator is unrelated to Trypho's question, who never doubted this to begin with. It is, however, relevant to the discussion between demiurgical and retrospectively orthodox forms of Christianity. Justin indicates that he will 
explain why the Mosaic Law is no longer valid without resorting to the demiurgical position according to which the Law was instituted by an inferior divine being and for that reason did not have to be observed.

Such passages have usually been dismissed as echoes from Justin's previous anti-heretical engagements, but this requires the assumption that Justin was a careless author or editor who did not sufficiently alter these earlier sources to fit their new rhetorical setting. More importantly, it fails to recognize that virtually everything in the Dialogue is pertinent to the debate with demiurgical forms of Christianity. Moreover, such anti-demiurgical passages are found not in isolated sections but throughout the entire Dialogue. For all these reasons, I contend that it is more compelling to read them as part of the intellectual work that Justin intended the Dialogue to do.

Chapter 4 related Justin's interest in evangelizing Jews to his struggle against "heresies." Rather than concluding from Justin's interest in combatting "heretical" views that the whole engagement with Jewish interlocutors was nothing but an elaborate literary device, this chapter offered an alternative solution. It noted the importance of Jewish conversions (or rather the lack thereof) to the debate between demiurgical and non-demiurgical forms of Christianity. Tertullian confirms that the lack of Jewish converts was cited against the retrospectively orthodox view that the Jewish Scriptures referred to Jesus. If the Scriptures had Jesus in mind, demiurgical Christians argued, Jews would have been the first to recognize him as their promised Messiah. Consequently, for Justin, converting Jews and combatting demiurgical "heresy" were two sides of the same coin. If he could succeed in convincing Jews that Jesus was the one promised in their Scriptures, this would help refute the demiurgists' claim that the Jewish Scriptures were unrelated to the figure of Jesus. In other words, Justin certainly did intend to persuade Jewish contemporaries and likely hoped that his internal audience would emulate his conversionary attempts, but this does not in any way diminish his interest in refuting "heretics." To the contrary, the two aims are intimately connected.

The surprising lack of conversions at the end of the Dialogue, then, may be seen as a function of Justin's acknowledgment that the great majority of Jews did not convert. Any other result would have ignored this problem and would have failed to refute his opponents' forceful argument. But in response to their views, Justin argued that the lack of conversions had nothing to do with any lack of force in the proof-from-prophecy argument. By having Trypho and his friends frequently assent to Justin's claims, the Dialogue suggests that when Jews are presented with the scriptural proofs they actually find them compelling. The lack of converts must have been due to other factors. Justin's most important explanation for this is the Jews' hardheartedness, i.e. their sheer unwillingness or inability to draw the "obvious" conclusion from the evidence presented to them. In making this point, Justin offers harsh scoldings of the Jews in general and Trypho in particular, even though his scoldings stand in tension with Trypho's willing acceptance of much of what Justin has to say, as well as with Justin's very attempt to convert Trypho. Like the unexpected ending of the text, these apparent inconsistencies can be better 
explained by reading the Dialogue as a response to the concerns and objections of Justin's demiurgical contemporaries.

Various other aspects of the Dialogue also make better sense when read in the context of intra-Christian debate. These include the text's literary setting shortly after the Bar Kochba revolt and the focus on Greco-Roman philosophy in the introductory chapters. The setting of the Dialogue shortly after the Bar Kochba revolt despite the fact that the work itself was only published many years later can be explained in terms of the impetus that the Bar Kochba revolt provided to Christian theologies that characterized the Jewish God as inferior. This most recent, devastating defeat of the Jewish people and by extension their God constituted compelling proof that this figure was not the Supreme Being. The Dialogue's literary setting afforded Justin the opportunity to defend the supremacy of the Jewish God in direct response to this forceful argument against it.

The focus on Greco-Roman philosophical schools in the opening chapters of the Dialogue likewise requires explanation. Trypho and Justin share a deep respect for the Jewish Scriptures, which would accordingly be their conversation's expected starting point. So why did Justin spend his first several chapters harshly criticizing contemporary philosophy, in particular Platonism? This choice becomes intelligible upon recognizing that the demiurgical theologies that Justin opposed could claim compatibility with that revered philosophical tradition. By identifying intellectual problems with the Platonic model, Justin simultaneously challenged the credibility of theories advanced by his demiurgical opponents. In sum, many of the most puzzling and remarkable features of the Dialogue can be better or more fully explained if we situate the document in a context of contestation between demiurgical and retrospectively orthodox forms of Christianity.

Finally, Chapter 5 turned to passages in the Dialogue that directly refer to the Christian "heresies." The opponents that Justin attacks in these passages are, once again, demiurgical Christians. Whereas older scholarship sometimes construed these sections as interludes or excurses that had little to do with the argument of the Dialogue as a whole, I argued that they are better understood as moments that render explicit Justin's anti-heretical interest throughout the Dialogue.

These attacks on rival Christians had a clear function for Justin's internal audience. Their place within the literary setting of the conversation with Trypho is more puzzling, though, because in contemporary apologetic literature the norm was to emphasize the unity of one's own tradition and not draw attention to any internal discord. This emphasis was imperative because dissent carried a wide range of negative associations in the Greco-Roman world. I argued, however, that Justin's choice to broach this topic made sense because it allowed him to present Trypho with a form of Christianity that was maximally appealing since it radically excluded as "heresy" certain notions that were particularly offensive to many Jews, including the consumption of idol meat and blasphemy of the Jewish God. Despite the advantages of heresiology, Justin must have realized that drawing attention to diversity and dissent among Christians carried considerable risks. In response, he minimized any potential disadvantages by presenting the presence 
of "heresies" as the fulfillment of prophecy, suggesting that their appearance confirmed rather than undermined the credibility of the Christian message, and by insisting that rival ideological groupings such as the Greco-Roman philosophers and, crucially, the (non-Jesus-believing) Jews were as divided as the Christians if not more so.

To establish this last point, Justin made a number of assertions about Jewish haireseis that have been accepted by much scholarship as essentially reliable reflections of contemporary Jewish heresiology. But in the crucial passage in Dial. 80, Justin does not in fact claim that certain Jews regarded other Jews as "heretics," but rather that they would do so, if they "considered the matter carefully." This is a prescriptive, not a descriptive statement. Justin seeks to make the point that the Jews were just as divided as the Christians, despite the fact that Jewish teachers did not usually reject wayward members of the community as non-Jews (Dial. 140.2). Moreover, in much of what he says in connection to Jewish haireseis, Justin reflects influence from Acts of the Apostles, not an intimate knowledge of contemporary Judaism(s). The likelihood that Justin was familiar with Acts and reflects the influence of this text especially also when he refers to Jewish haireseis will be argued more closely in the appendix of this study.

Justin's statements about Jewish "heresies" accordingly cannot be taken as reliable description of contemporary Jewish discourse and this calls into question scholarly reconstructions of contemporary Judaism(s) that assume their historical reliability, as well as the scholarly view that there was a well-developed Jewish heresiology prior to or contemporary with Justin. The Dialogue's alleged description of Jewish "heresies" finds too little corroboration in other extant sources to be accepted as a straightforward, reliable account and the notion that the Dialogue's statements are reflective of contemporary Jewish heresiology is ultimately based to a considerable degree on a misreading of Justin's text.

This chapter finally argued that with respect to the Dialogue's internal audience, the function of Justin's statements about "heresies" was not simply to identify his opponents as "heretics" but to argue in favor of the heresiological approach itself. Justin was writing in a context in which "heresy" was a relatively new (indeed, arguably not yet fully formed) concept and strict boundaries between various kinds of "Christians" were still rarely drawn. By demonstrating the utility of heresiology in the conversation with Trypho while minimizing its disadvantages by, inter alia, presenting rival traditions as at least as divided, Justin offered a clear commendation of this forcefully exclusionary approach to his internal audience. In so doing, Justin sought to convince them of the expediency and feasibility of this aggressive response to self-identified Christians whose views differed from his own.

Pierre Prigent once noted that Justin was remembered in the early church primarily as an opponent of heresy rather than as an apologist, theologian or specialist on Judaism. ${ }^{1}$ The present study has borne out that assessment of Justin's focus, not only with respect to the Syntagma and $1 \mathrm{Apol}$., but also and especially with regard to the Dialogue, which has emerged as a remarkably rich and multifaceted text that is doing significantly more than simply defending Christianity over 
against Judaism. While Justin was by no means only interested in combatting demiurgical Christians, that aim did play an important role in the composition of the Dialogue and, indeed, throughout his entire career. And Justin's efforts paid off. His advocacy of a non-demiurgical, heresiological form of Christianity would be adopted by Irenaeus, Tertullian and other early church figures and would ultimately have a decisive impact on the shape of Christianity.

\section{Note}

1 Prigent, Justin et l'Ancien testament, 12. 


\section{APPENDIX \\ Justin Martyr and Acts of the Apostles}

The discussion of the "seven Jewish heresies" of Dial. 80 in Chapter 5 raised the possibility that Justin was influenced by Acts in formulating this list (see above, pp. 110-113). That Justin knew Acts is not, however, generally accepted; most scholars remain agnostic on the issue. ${ }^{1}$ This leads to an important observation: discussions of the possible attestation of Acts by Justin have not taken the list in Dial. 80 into account, even though virtually all scholars who have worked on that list connect at least one of its items with Acts. Scholars working on Justin's catalogue of Jewish "heresies," conversely, have ignored or overlooked the larger question of Justin's familiarity with Acts. Whether or not Justin is dependent on Acts is important both for the study of Justin's writings as well as Acts. If Justin can be shown to have used Acts, this would be the earliest securely datable attestation of Acts, whose date has been subject to significant debate in recent years. ${ }^{2}$ I argue in this appendix that the cumulative evidence suggests that Justin was indeed aware of and made use of Acts.

The question of Justin's knowledge of Acts should not be reduced to a false dichotomy between no contact at all or pervasive influence. The tacit logic behind many discussions, especially in commentaries on Acts, is that if Justin was aware of Acts, he must have regarded it as authoritative (a word sometimes little more than a cipher for "canonical") and hence would have cited it frequently and clearly. In other words, so the argument sometimes goes, because Justin does not cite Acts unambiguously, he must not have been aware of it. I propose to approach the issue differently and simply ask: What is the easiest way to account for the evidence presented below? There are different ways of explaining the various parallels including positing hypothetical intermediary sources or ascribing all similarities to unprecedented levels of coincidence or a remarkably strong oral tradition. ${ }^{3}$ It is far more economical, I suggest, to accept that Justin drew on Acts directly.

We should note at the outset that it cannot be assumed that the Gospel of Luke and Acts circulated together. ${ }^{4}$ This means that even if it can be decisively demonstrated that Justin drew on Luke, this does not settle the question for Acts. In terms of the evidence of Justin's knowledge of Acts specifically, the scholarly discussion has not always been as thorough as one might expect. ${ }^{5}$ Ernst Haenchen claimed that the proximity of 1 Apol. 50.12 to Acts 1:8-9 provided decisive 
evidence of Justin's knowledge of Acts, and scholarly discussion since then has mostly focused on this passage. ${ }^{6}$ Two otherwise significant contributions, Richard Pervo's Dating Acts and Andrew Gregory's The Reception of Luke and Acts in the Period Before Irenaeus restrict themselves almost entirely to this single parallel between Justin and Acts. Both scholars have a point when they reject Haenchen's claim that this is "the decisive reference," but they are too quick to dismiss the passage's significance entirely.

\section{Apol 50.12}

and after they had seen him going up to heaven and had believed and had received power sent from him thence to them and had gone to every race of human beings, they taught these things and were called apostles

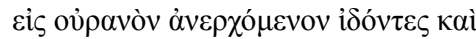

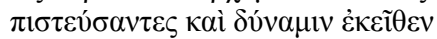

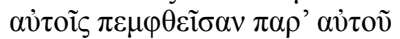

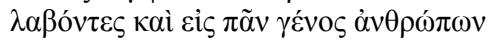

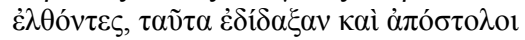
$\pi \rho о \sigma \eta \gamma о \rho \varepsilon v ́ \theta \eta \sigma \alpha \nu$

\section{Acts 1:8-9}

But you will receive power when the Holy Spirit has come upon you; and you will be my witnesses both in Jerusalem, and in all Judea and Samaria, and to the ends of the earth. When he had said this, as they were watching, he was lifted up, and a cloud took him away from their eyes

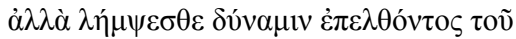

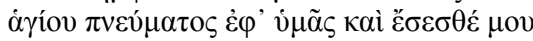

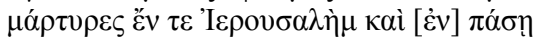

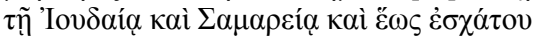

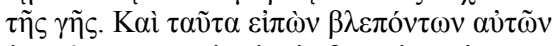

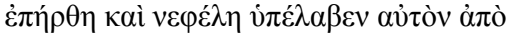
$\tau \tilde{\omega} v \dot{o} \varphi \theta \alpha \lambda \mu \tilde{\omega} v \alpha v ่ \tau \tilde{\omega} v$

As both Pervo and Gregory note, most of 1 Apol. 50.12 is paralleled not only in Acts but also in Matthew and Luke. There are two elements, however, that Acts and $1 \mathrm{Apol}$. have in common that are not shared by any of the other ascension

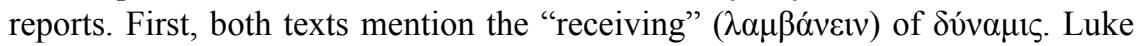
24:49 also describes a transfer of power, but there the governing verb is "to clothe

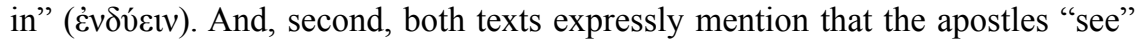
( $\beta \lambda \varepsilon \dot{\varepsilon} \varepsilon \imath v)$ Jesus ascend, a detail absent from the Gospels.

There are a number of other cases in Justin's corpus where the details are noticeably similar. For instance, when referring to the divine promise to David that one of his descendants would sit on his throne, both Dial. 68.5 and Acts 2:30 contain

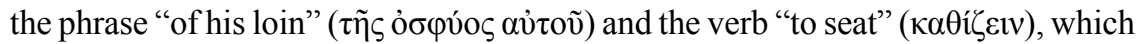
are absent from LXX Ps 131:11b, the verse on which both Justin and Acts drew.

\section{Dial. 68.5}

of his loins God would take to himself a Son ... and would seat him upon the throne
Acts 2:30

[God had sworn with an oath to him] to seat someone from the fruit of his loins on his throne 


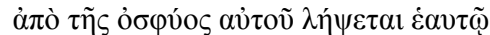

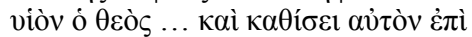
$\theta$ óvov....

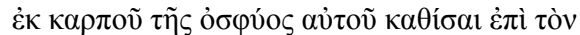

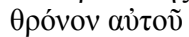

In other cases the verbal overlap is limited, but the relevant passages in Justin and Acts nonetheless bear some similarity. Here we must include 1 Apol. 39.3,

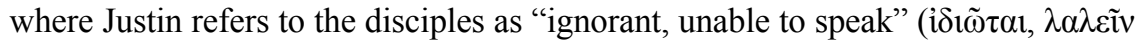

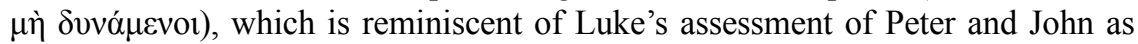

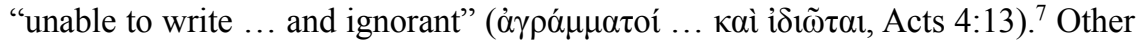
examples include (1) Dial. 80.3: "I choose not to be a follower of men or of

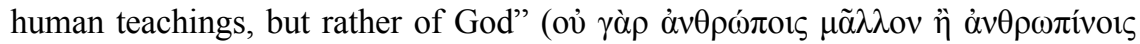

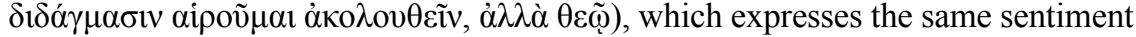
as Acts 5:29: "we must obey God rather than men" ( $\pi \varepsilon 1 \theta \alpha \rho \chi \varepsilon \tilde{\imath} v \delta \varepsilon \tilde{i} \theta \varepsilon \tilde{\varphi} \mu \tilde{\alpha} \lambda \lambda$ ov $\eta$ $\dot{\alpha} v \theta \rho \omega ́ \pi 01 \varsigma$, cf. 4:19), and (2) 1 Apol. 10.1: "But seeing that God provides all things, we have learned that God has no need of material services from human beings"

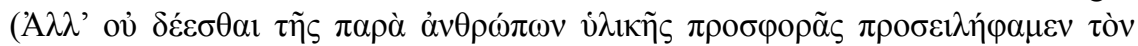

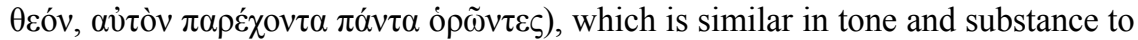
Acts 17:25: "nor is he served by human hands, as though he needed anything, since

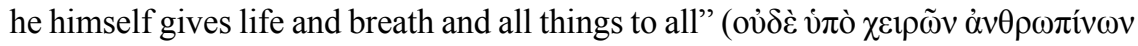

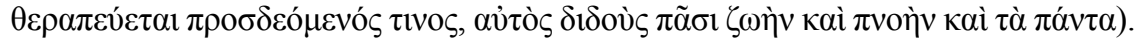

In other instances, contact between Acts and Justin is suggested by the combination of elements that they have in common. For example, Dial. 16.4 and Acts 7:52 share the following five elements: they charge the Jews/Jewish leaders with killing ( $\dot{\alpha} \pi 0 \kappa \tau \varepsilon i ́ v \varepsilon v v)$ the prophets (\#1) who announced the coming of the Messiah (\#2). The Messiah is called "the righteous one" (\#3) and was also attacked by the Jews (\#4), along with those who believe in him (\#5). ${ }^{8}$ Both passages present a triptych of Jewish persecution: first the prophets, then the "Just One" and now those believe in him:

Dial. 16.4

For you have murdered the Just One and his prophets before him and now those who hope in him

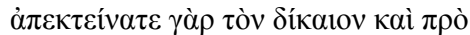

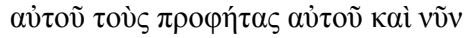

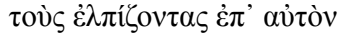

Acts 7:52

They killed those who foretold the coming of the Just One, and now you have become his betrayers and murderers

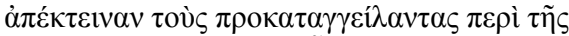

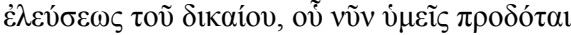

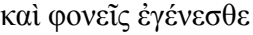

Another example is offered by 1 Apol. 40.6-11 and Acts 4:25-28, which quote the same text (Psalm 2), ascribe it to David and take it to refer to Herod, Pilate, the Jews and the Gentiles (or in Justin's case, more specifically, Pilate's soldiers): 


\section{Apol. 40.5-11}

we consider it good and appropriate to make mention also of other words that were prophesied through the same David ... and how he signifies that there was a coming together of Herod, the king of the Jews, and the Jews themselves, and Pilate, who was your procurator among them, together with his soldiers against the Christ. ... They [the words] were spoken as follows. ... "Why did the Gentiles rage and the peoples imagine new things? The kings of the earth took their stand, and the rulers have gathered together against the Lord and his Messiah"

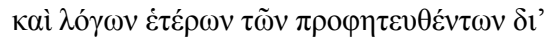

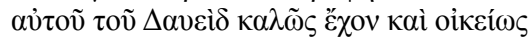

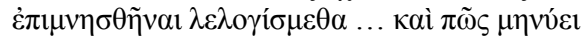

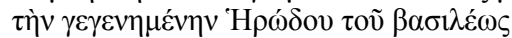

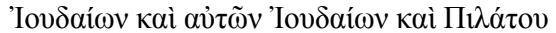

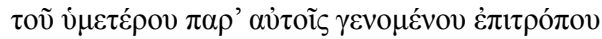

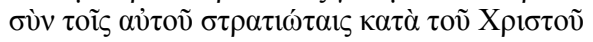

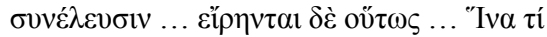

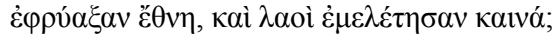

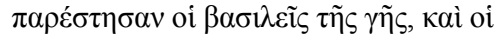

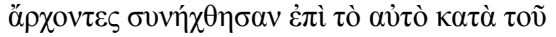

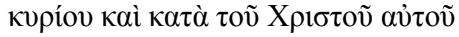

\section{Acts 4:25-28}

the one saying by the Holy Spirit through our ancestor David, your servant: "Why did the Gentiles rage, and the peoples imagine vain things? The kings of the earth took their stand, and the rulers have gathered together against the Lord and against his Messiah." For in this city, in fact, both Herod and Pontius Pilate, with the Gentiles and the peoples of Israel, gathered together against your holy servant Jesus, whom you anointed

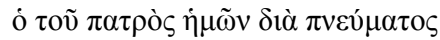

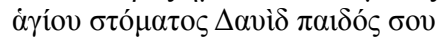

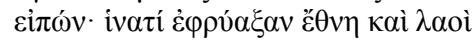

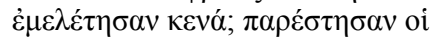

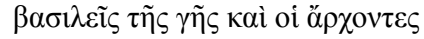

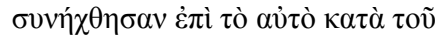

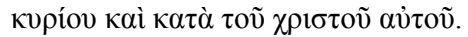

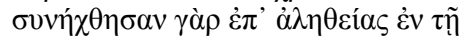
$\pi$

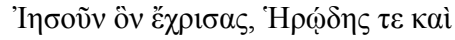

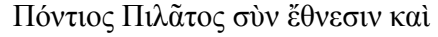

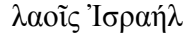

These verbal and logical congruences constitute a truly remarkable coincidence if we assume that there is no connection of any kind between Justin and Acts. ${ }^{9}$

A final instance in this category is the overlap between 1 Apol. 49.5 and Acts 13:27-52:

\section{Apol. 49.5}

For the Jews, who have the prophecies ... did not recognize him.... But those who belonged to the Gentiles ... hearing ... being filled with joy and faith

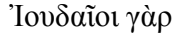

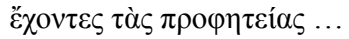

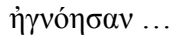

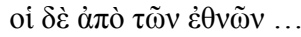

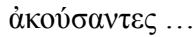

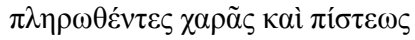

\section{Acts 13:27-52}

Because the residents of Jerusalem and their leaders did not recognize him or understand the words of the prophets. ... 48: When the Gentiles heard this, they rejoiced and ... believed ... 52: (And the disciples) were filled with joy and with the Holy Spirit

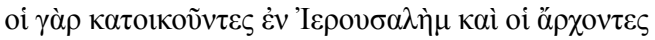

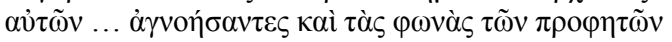

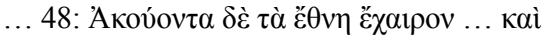

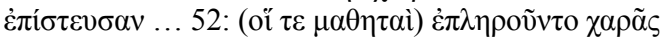

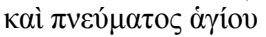


Haenchen has noted the conceptual and verbal proximity between the phrase

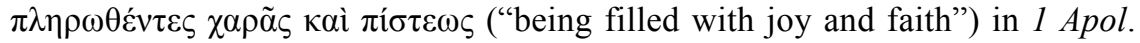

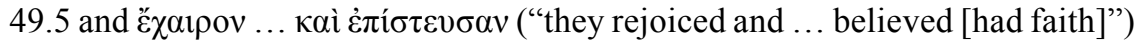
in Acts 13:48. ${ }^{10}$ But the similarities go further still. The verb $\pi \lambda \eta \rho$ povv appears

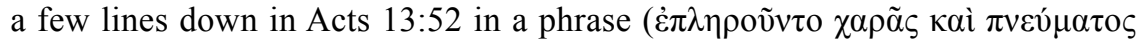

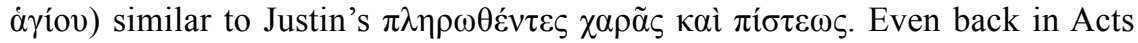
13:48 the parallelism is somewhat more extensive than Haenchen allows. Both

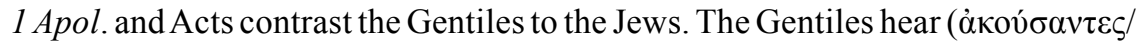
$\dot{\alpha} \kappa o v ́ o v \tau \alpha$ ) the message and, by way of response, come to faith and rejoice. The Jews, by contrast, have heard the message many times before, but they refuse to believe. Justin states that they have access to the very prophecies that predict the coming of the Messiah but are ignorant (ì $\gamma v$ ó $\sigma \alpha v$ ). The same contrast is set up in Acts, when Luke depicts the inhabitants of Jerusalem and their rulers as ignorant ( $\dot{\alpha} \gamma v 0 \eta$ f $\sigma \alpha v \tau \varepsilon \varsigma$ ) with respect to the prophetic voices. In both cases, the Jews, even though they are familiar with the prophecies, do not believe, whereas the Gentiles upon hearing the message are immediately filled with joy and faith. There are other themes in this section of Acts 13 that may also have resonated with Justin: Luke's claim that the rejection of the Jews in favor of the Gentiles (13:46) is predicted in biblical prophecy (13:47) and that the response of the Jews consisted of blasphemy (13:45) and persecution (13:50) are all themes that Justin engages in the Dialogue. This brings us to an important observation: many of the parallels with the Dialogue are found in passages in Acts that touch upon the relation between Jews and Christians and read this fraught relationship as a configuration of biblical prophecy. It is a reasonable supposition that Justin encountered these passages in Acts and that the traces they left on his thinking are reflected on the pages of the Dialogue and the Apologies to which we have drawn attention.

Shared expressions that are otherwise unattested in literature of the period constitute perhaps the most persuasive evidence. For instance, ö $\gamma v \omega \sigma \tau o \varsigma \theta \varepsilon o ́ \varsigma$ ("unknown god") occurs in 2 Apol. 10.6 and Acts 17:23, but it is not attested elsewhere in the singular before Irenaeus. After Irenaeus, the phrase is found in Christian sources that are familiar with Acts and usually have Acts 17:23 in mind (cf. Irenaeus, A.H. 1.23.2, Clement of Alexandria, Strom. 1.19.92.2-2, 5.12.82.4,

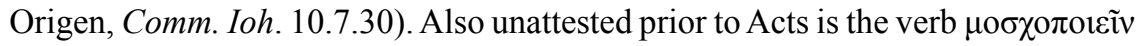
("calf-making"), which Luke uses once (Acts 7:41) and Justin employs multiple times (Dial. 19.5, 102.6, 132.1; cf. 73.6 and 20.4). Similarly, the phrase kotvò ì $\dot{\alpha} \kappa \alpha ́ \theta \alpha \rho \tau \alpha$ ("profane or unclean"), which Justin uses in the context of a discussion about food laws (Dial. 20.3), lacks prior attestation; the adjectives кolvó $\varsigma$ and $\dot{\alpha} \kappa \alpha \dot{\alpha} \theta \alpha \rho \tau$ $\sigma \varsigma$ do not appear in close conjunction in earlier literature, except for Acts

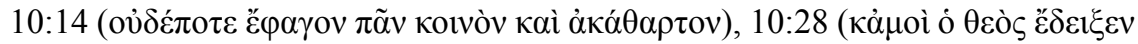

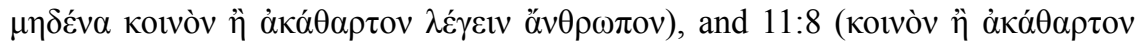

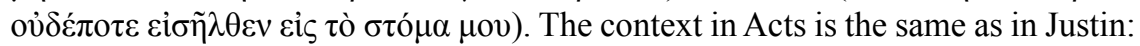
discussion of which foods are fit for consumption. Another example is Justin's use

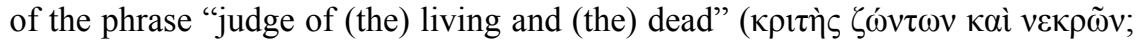


Dial. 118.1, cf. 36.1 and 49.2,132.1), which is not attested elsewhere prior to Acts 10:42 (cf. Polycarp, Phil. 2.1; Acts of John 8).

Finally, evidence that is especially significant for our argument that Justin's comments about the seven Jewish "heresies" of Dial. 80 were influenced by Acts, is found in connection with other claims Justin makes about Jewish haireseis. Justin refers to the Christians as a hairesis from the Jewish perspective multiple times, and, in connection to this, to Jewish persecution of the Christians. Various claims made in the relevant passages suggest influence from Acts.

The first pertinent passage is Dial. 17.1-3:

after you [i.e., the Jews] perceived that he had risen from the dead and had ascended into heaven, as the prophecies predicted would happen, you not only did not repent from your evil actions, but then, having chosen elected men from Jerusalem, you sent them out into the entire world saying that a godless hairesis of Christians had appeared, reiterating the things that all those who are ignorant about us say against us. Therefore you are the cause of injustice not only for yourselves but for all people in general. Isaiah justly cries out: Because of you my name is blasphemed among the Gentiles (Isa 52:5) ... You have been eager to make sure that bitter, dark, and unjust accusations would be reiterated in every land. ${ }^{11}$

The claim that the Jews sent out people everywhere to go after the "godless hairesis of Christians" is mentioned again towards the end of the Dialogue. In 108.2, Justin again stresses the refusal of the Jews to repent:

You not only did not repent despite learning that he had risen from the dead, but, as I said before, you sent handpicked, chosen men into the entire inhabited world, proclaiming that a certain godless and lawless hairesis had originated with a certain Jesus, a Galilean deceiver. ${ }^{12}$

Justin picks up the same theme once more in Dial. 117.3:

The high priests of your people and your teachers worked hard to have his name be profaned and blasphemed throughout the entire earth (cf. Isa 52:5). But those filthy garments, which are placed by you upon all those who by the name of Jesus have become Christians, God will show to be thrown off us when he raises up everyone. ${ }^{13}$

In this last passage the word hairesis is absent. However, the recurrence of Isa 52:5 (cf. Dial. 17.1-2) together with the reference to the "filthy garments" of Zech 3:1-7 that the Jewish leaders are said to have placed on the Christians indicate that Justin has the same theme of organized opposition to the Christians squarely in view..$^{14}$ 
The language and content of these passages reinforce the impression that Justin was familiar with Acts and that this document exerted a particular influence on his understanding of Jewish haireseis. Several details in the Dialogue may plausibly be derived from Acts and are not attested in any other contemporary source. ${ }^{15}$ Only according to Acts did the Jews refer to the early Christian movement as a hairesis (Acts 24:5,14; 28:22). To the best of my knowledge, this is unparalleled in any other contemporary Jewish or Christian source. In Acts, the Jews call the Christian group a hairesis in the context of their attack against Paul. Justin similarly associates the Jews' reference to the Christians as a hairesis with Jewish persecution.

Justin's claims about Jewish propaganda and persecution may very well have been influenced by the description of Paul's persecutory activities in Acts (chs. 9, $22,26)$. One telling detail is the involvement of the "high priests," which was anachronistic in Justin's time, but matches the accounts of Paul's pre-Christian activities in Acts 9:1-2, 22:4-5, and 26:10-11. The latter passage is particularly interesting, because there we find, as in Justin, the plural $\dot{\alpha} \rho 1 \varepsilon \rho \varepsilon i \bar{c}:$ not a single high priest, but multiple high priests were involved in the Jewish persecution of Christians, according to both Acts and Justin. Moreover, according to that same passage in Acts, Paul's goal was to force the Christians to blaspheme $(\beta \lambda \alpha \sigma \varphi \eta \mu \varepsilon i v)$. Blaspheming is likewise the outcome of the actions of the high priests and teachers, according to Justin (Dial. 17.2, 117.3). ${ }^{16}$

The idea of Jewish leaders dispatching people abroad for propagandistic and persecutory purposes is also without precedent anywhere in extant literature of the period except for Acts. That Paul was a persecutor is attested in Galatians 1, Philippians 3, and 1 Corinthians 15, but only in Galatians is there any hint that this took place outside of Judea. ${ }^{17}$ That point is stated unequivocally only in Acts. Moreover, outside of Acts, no claim is made that Paul's activities were officially sanctioned. The possibility that Paul himself regarded the persecution of Christians as closely bound up with his Pharisaic identity (cf. Phil 3:5-6, Gal 1:13-14) does not amount to any kind of official authorization. One might object that, according to the account of Acts, persecution is not explicitly attested beyond Damascus, while Justin claims that the persecutors went everywhere (Dial. 17.1; cf. 17.3). However, Acts 26:10-11 suggests that Paul's persecutory activities were extensive. As Richard Pervo notes, "The journey to Damascus is now but one example of his [i.e. Paul's] properly authorized anti-Christian expeditions." ${ }^{.8}$ Acts 28:21-22 likewise imagines worldwide Jewish opposition to the Christians: the Jewish leaders state that the Christian hairesis is "spoken against everywhere"

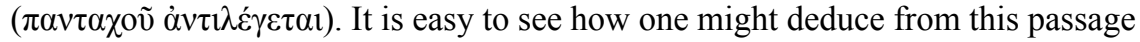
that messengers from Judea were traveling around "everywhere" to oppose the hairesis of the Christians.

Additionally, Justin's notion of a number of men elected specifically to travel from Jerusalem in order to distribute this message abroad may well have originated with Acts 15, where the Christian leaders, by common consent, decide to dispatch $(\pi \varepsilon ́ \mu \psi \alpha \mathrm{l}[15: 22,25])$ from Jerusalem a specifically selected group of men 


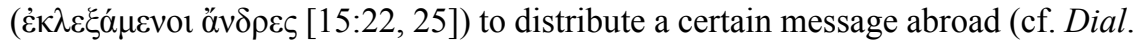

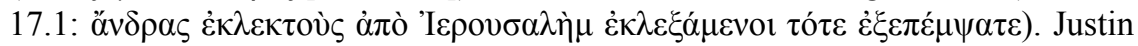
perhaps imagined that the early Christians of Acts 15 followed Jewish protocol.

Finally, Justin notably characterizes Jewish persecution of Christians in Dial. 26.1 as the "persecution of Christ." He does so not only with reference to the time that Jesus was alive and was personally targeted by Jewish leaders but also when referring to the present. Justin is not saying that the followers of Jesus are

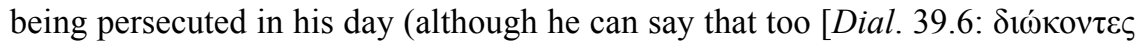

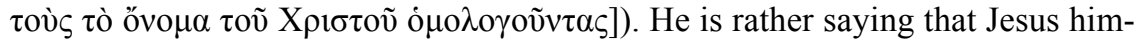
self is, in the present day, being persecuted by Jews. Justin refers to these Jews

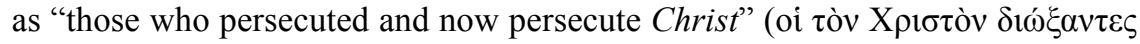

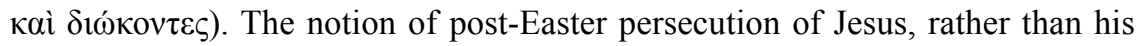
followers, is not attested anywhere else except for Acts, where Paul relates how during his Damascus experience Jesus asked, "why do you persecute me? ... I

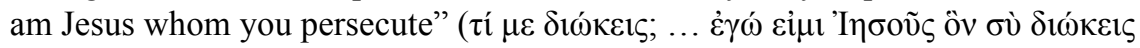
[Acts 9:4-5, cf. 22:7-8; 26:14-15]). Again, this suggests that especially in the passages in which Justin addresses Jewish opposition to Christianity he was influenced by Acts.

The cumulative evidence discussed in this appendix is best explained, I suggest, by positing that Justin was aware of Acts. This is the most economical explanation of the overlap between the texts. The fact that Justin does not explicitly cite or quote directly from Acts does not refute this conclusion. It is part of Justin's apologetic strategy to cite only the old, venerable writings of the LXX as witnesses and not to depend explicitly on the literary products of his own time or a few generations earlier. The only exception to this general rule is the words of the Lord himself as transmitted through the "Memoirs of the Apostles." 19 The absence of direct appeals to Acts is therefore exactly what one would expect; it is the opposite that would require explanation. Perhaps an additional reason for the lack of explicit references to Acts is precisely that Justin has derived some of his knowledge of contemporary Judaism from this document. The literary character "Justin" is presented as eminently suited to the task of debating Trypho, because he has expert knowledge of Judaism. ${ }^{20}$ As an expert on Jewish traditions and interpretations, he can make authoritative statements about their inferiority to their Christian counterparts. Appealing to a Christian document like Acts as an authoritative source on Jews and Judaism would threaten the learned status and standing of the literary character "Justin" and, consequently, diminish the efficacy of his strategy and the persuasive appeal of his text. Simply put, Justin could not have plausibly presented himself as an expert on all things Jewish if he admitted via citation or some other means that Acts was actually his source for these matters.

There is, in short, no point in denying familiarity with Acts on Justin's part on the basis of his failure to clearly quote this document. There is enough evidence to render it plausible that Justin had read Acts. This does not mean that Justin regarded all of Acts as bindingly authoritative (let alone "canonical"). Indeed, the divergent portrayals of Simon Magus in Acts 8 and 1 Apol. 26 suggest that Acts 
was not universally authoritative for him, at least not on this particular topic, about which Justin (who also hailed from Samaria) considered himself well-informed. ${ }^{21}$ Moreover, Skarsaune, who also believes that Justin probably read Acts, observes that "on the level of proof-texts, there is surprisingly little in common between Luke and Justin's 'kerygma' testimonies." ${ }^{22}$ Such a lack of commonality signals that the influence of Acts on this aspect of Justin's thinking was limited. But this does not alter the fact that there is considerable evidence to suggest that Justin had encountered Acts of the Apostles and had been influenced by it on a number of points.

\section{Notes}

1 Others are certain that no influence can be detected. Cf., e.g., Robert M. Grant, Irenaeus of Lyons, The Early Church Fathers (London; New York: Routledge, 1997), 17: "Justin ... did not use Acts."; Rajak, "Apologetic," 77: Justin "seems to have known Matthew, Luke, and Corinthians, though not Acts." Susan J. Wendel, Scriptural Interpretation and Community Self-Definition in Luke-Acts and the Writings of Justin Martyr, NovT Supplements 139 (Leiden; Boston: Brill, 2011), 4-7 offers a recent overview of scholarly opinion.

2 Richard I. Pervo, Dating Acts: Between the Evangelists and the Apologists (Santa Rosa, CA: Polebridge Press, 2006), 23 regards Irenaeus as "the earliest certain witness to the existence of Acts." Similarly, Charles Kingsley Barrett, A Critical and Exegetical Commentary on the Acts of the Apostles, ICC (Edinburgh: T \& T Clark, 1994), 1:15; Andrew F. Gregory, The Reception of Luke and Acts in the Period before Irenaeus: Looking for Luke in the Second Century, WUNT 2.169 (Tübingen: Mohr Siebeck, 2003), 350-2.

3 One could, in theory, also posit influence in the other direction (the author of Acts drew on Justin), but this would require an extraordinarily late date for Acts, which does not cohere well with other data that suggest a date in the first half of the second century $\mathrm{CE}$ at the latest (for a comprehensive discussion, which takes into account a wide range of evidence, see Pervo, Dating Acts).

4 See Mikeal C. Parsons and Richard I. Pervo, Rethinking the Unity of Luke and Acts (Minneapolis: Fortress Press, 1993); C. Kavin Rowe, "History, Hermeneutics, and the Unity of Luke-Acts," JSNT 28 (2005): 131-57; Andrew F. Gregory and C. Kavin Rowe, eds., Rethinking the Unity and Reception of Luke and Acts (Columbia, SC: University of South Carolina Press, 2010).

5 Previous discussion include Ernst Haenchen, The Acts of the Apostles: A Commentary (Philadelphia: Westminster Press, 1971), 8-9; Hans Conzelmann, Acts of the Apostles: A Commentary on the Acts of the Apostles, Hermeneia (Philadelphia: Fortress Press, 1987), xxx-xxxi; Édouard Massaux, The Influence of the Gospel of Saint Matthew on Christian Literature before Saint Irenaeus, Vol. 3: The Apologists and the Didache (Macon, GA: Mercer University Press, 1990), 46, 94; Barrett, Acts, 1:41-4; Gregory, The Reception of Luke and Acts, 317-21; Charles H. Talbert, Reading Acts: A Literary and Theological Commentary on the Acts of the Apostles, rev. ed., Reading the New Testament (Macon, GA: Smyth \& Helwys, 2005), 1; Pervo, Dating Acts, 20-2.

6 Haenchen, The Acts of the Apostles: A Commentary, 8-9.

7 My very literal translation of both passages is meant to bring out the similarity evident in the Greek. In both cases, the sense is that the apostles were not very well educated, not that they were mute $(1 \mathrm{Apol}$.) nor even necessarily that they were completely illiterate (Acts). On this last point, see, e.g., Herbert C. Youtie, "АГРАММАТО : An Aspect of Greek Society in Egypt," Harvard Studies in Classical Philology 75 (1971): 161-76. 
8 The final point is implied in Acts 7: Stephen, who utters this statement, is stoned to death shortly after.

9 Justin develops the exegesis of Psalm 2 more extensively in the immediate context, but this does not alter the significance of the similarities with Acts in the section quoted.

10 Haenchen, The Acts of the Apostles: A Commentary, 8. Barrett, Acts, 1:42, for some reason connects 1 Apol. 49.5 with Paul's Areopagus speech, with which he subsequently finds little overlap: "It contains nothing about the prophecies, and does not seem to have led to much joy and faith." These elements are, however, present in Acts 13.

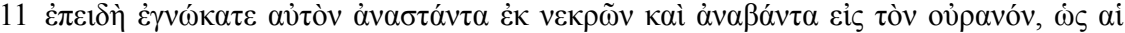

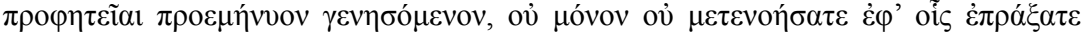

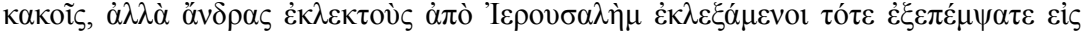

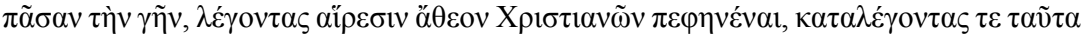

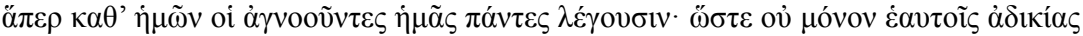

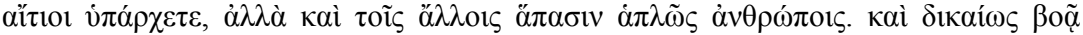

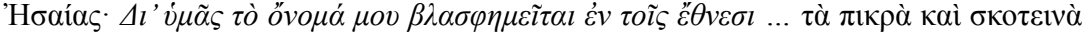

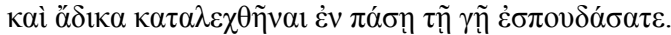

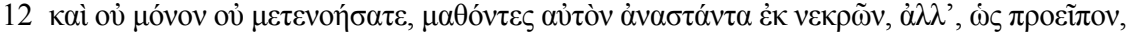

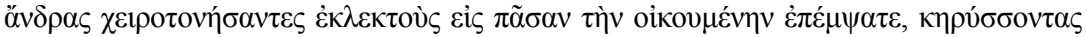

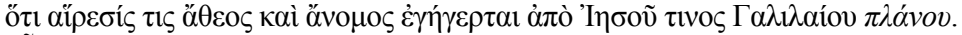

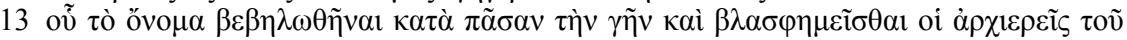

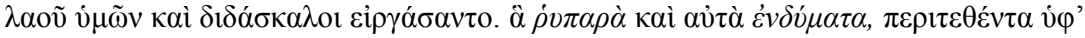

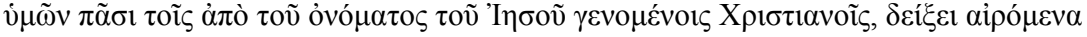

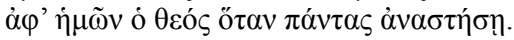

14 Cf. also Dial. 120.4.

15 William Horbury, "Jewish-Christian Relations in Barnabas and Justin Martyr," in Jews and Christians: The Parting of the Ways, A.D. 70 to 135, ed. James D. G. Dunn, WUNT 66 (Tübingen: Mohr Siebeck), 1992), 342, claims that Justin derives his information from a tradition that was informed by passages from Isaiah: "one may suspect a testimony-registration of the story of the anti-Christian emissaries, using texts from Isaiah, a book widely read as a prophecy of Jewish-Christian relations." However, in support of the existence of such a testimony tradition, Horbury can point only to allusions to different verses from Isaiah in connection with the reports about Jewish emissaries (Eusebius and Hippolytus drew on Isa 18:1-2, whereas Justin quotes Isa 52:2, 3:9-11 and 5:18-20 in Dial. 17.2).

16 Acts most likely has blaspheming of Jesus in mind (so, e.g., Conzelmann, Acts of the Apostles, 210), which is the case for Justin as well (Dial. 117.3, 120.4).

17 This is suggested by the combination of Gal 1:13 (Paul persecuted the church), 1:17 (Paul was in Damascus at some point) and 1:22 (Paul was personally unknown to the Judean churches).

18 Pervo, Acts, 631.

19 Cf. 1 Apol. 23.1: "only the things which we say that we learned from Christ and the prophets who came before him are true." Note, though, Justin's brief nod to John's Apocalypse in Dial. 81.4.

20 Justin in fact presents himself as a late antique homo universalis, who is versed in all philosophical schools (Dial. 1-9), has expert knowledge about all things Jewish and scriptural, and is a rhetorical expert. The latter point is cleverly established in Dial. 58.1-3 where Justin (the author) has Trypho respond with incredulity to the protestations of Justin (the literary character) that he does not have any special rhetorical skills (such protestations were, of course, common fare in rhetorical settings).

21 Cf. above, p. 20.

22 Skarsaune, The Proof from Prophecy, 432 (see also pp. 250-1, 255-9, 361-2, 431). Cf. Wendel, Scriptural Interpretation, who argues that although Justin and Acts share key themes and ideas, they develop them in different ways. 


\section{BIBLIOGRAPHY}

Alexander, Loveday. The Preface to Luke's Gospel: Literary Convention and Social Context in Luke 1.1-4 and Acts 1.1. SNTSMS 78. Cambridge; New York: Cambridge University Press, 1993.

Allert, Craig D. Revelation, Truth, Canon, and Interpretation: Studies in Justin Martyr's Dialogue with Trypho. VC Supplements 64. Leiden; Boston: Brill, 2002.

Andresen, Carl. Logos und Nomos: Die Polemik des Kelsos wider das Christentum. Berlin: Walter de Gruyter, 1955.

Archambault, Georges. Dialogue avec Tryphon. Textes et documents pour l'étude historique du christianisme, 8, 11. Paris: A. Picard, 1909.

Arnal, William E. "Doxa, Heresy, and Self-Construction: The Pauline Ekklēsiai and the Boundaries of Urban Identities." In Heresy and Identity in Late Antiquity, edited by Eduard Iricinschi and Holger M. Zellentin, 50-101. TSAJ 119. Tübingen: Mohr Siebeck, 2008.

Aune, David E. "Dedications (of Books)." In The Westminster Dictionary of New Testament and Early Christian Literature and Rhetoric, 123-4. Louisville, KY: Westminster John Knox, 2003.

Baarda, Tjitze. "Luke 12, 13-14, Tradition and Interpretation." In Christianity, Judaism and Other Greco-Roman Cults: Studies for Morton Smith at Sixty, Part One: New Testament, edited by Jacob Neusner, 107-62. Leiden: Brill, 1975.

Bagnall, Roger S. Early Christian Books in Egypt. Princeton, NJ: Princeton University Press, 2009.

Bakke, Odd Magne. "Concord and Peace": A Rhetorical Analysis of the First Letter of Clement with an Emphasis on the Language of Unity and Sedition. WUNT 2.143. Tübingen: Mohr Siebeck, 2001.

Barclay, John M.G. Against Apion. Flavius Josephus, Translation and Commentary. Vol. 10. Leiden; Boston: Brill, 2007.

Barnard, Leslie W. The First and Second Apologies. Ancient Christian Writers 56. New York: Paulist Press, 1997.

- Justin Martyr: His Life and Thought. Cambridge: Cambridge University Press, 1967.

. "The Old Testament and Judaism in the Writings of Justin Martyr." VT 14 (1964): 395-406.

Barrett, Charles Kingsley. A Critical and Exegetical Commentary on the Acts of the Apostles. 2 vols. ICC. Edinburgh: T\&T Clark, 1994. 
Bauer, Walter. Orthodoxy and Heresy in Earliest Christianity. Philadelphia: Fortress Press, 1979.

. Rechtgläubigkeit und Ketzerei im ältesten Christentum. 2nd ed. BHTh 10. Tübingen: Mohr Siebeck, 1964.

Berlinerblau, Jacques. "Toward a Sociology of Heresy, Orthodoxy, and Doxa." HR 40 (2011): 327-51.

Betz, Hans Dieter. "Orthodoxy and Heresy in Primitive Christianity." Interpretation 19 (1965): 299-311.

Bikerman, Elias. "Les Hérodiens." Revue Biblique 47 (1938): 184-97.

Birt, Theodor. Das antike Buchwesen in seinem Verhältniss zur Litteratur. Berlin: W. Hertz, 1882.

Black, Matthew. "Patristic Accounts of Jewish Sectarianism." Bulletin of the John Rylands Library 41 (1958-1959): 285-303.

Bobichon, Philippe. “Autorités religieuses juives et 'sectes' juives dans l'œuvre de Justin Martyr." Revue des Études Augustiniennes 48 (2002): 3-22.

- Justin Martyr, Dialogue avec Tryphon. 2 vols. Fribourg: Academic Press, 2003.

Bokser, Ben Zion. "Justin Martyr and the Jews.” JQR 64 (1973): 97-122.

Bowersock, Glen W. "Greek Intellectuals and the Imperial Cult in the Second Century A.D.” In Le culte des souverains dans l'Empire Romain. 7 exposés suivis de discussions, edited by E.J. Bickerman and W. den Boer, 177-212. Vandœuvres-Genève: Fondation Hardt; Dépositaire pour la Suisse: Francke, Berne, 1973.

Boyarin, Daniel. Border Lines: The Partition of Judaeo-Christianity. Divinations. Philadelphia: University of Pennsylvania Press, 2004.

Boys-Stones, George R. Post-Hellenistic Philosophy: A Study of Its Development from the Stoics to Origen. Oxford: Oxford University Press, 2001.

Brakke, David. The Gnostics: Myth, Ritual, and Diversity in Early Christianity. Cambridge, MA: Harvard University Press, 2010.

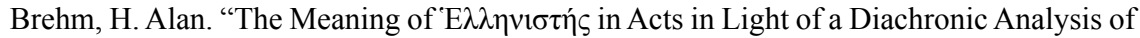

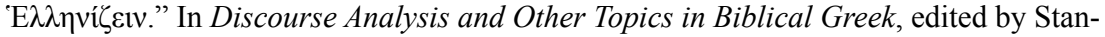
ley E. Porter and Donald A. Carson, 180-99. JSNT Supplement Series 113. Sheffield: Sheffield Academic Press, 1995.

Brent, Allen. Ignatius of Antioch and the Second Sophistic: A Study of an Early Christian Transformation of Pagan Culture. Tübingen: Mohr Siebeck, 2006.

Broek, Roel van den. "The Creation of Adam's Psychic Body in the Apocryphon of John." In Studies in Gnosticism and Hellenistic Religions: Presented to Gilles Quispel on the Occasion of His 65th Birthday, edited by R. van den Broek and M.J. Vermaseren, 38-57. Leiden: Brill, 1981.

Bruun, Christer. "Greek or Latin? The Owner's Choice of Names for Vernae in Rome." In Roman Slavery and Roman Material Culture, edited by Michele George, 19-42. Toronto: University of Toronto Press, 2013.

Bryen, Ari Z. Violence in Roman Egypt: A Study in Legal Interpretation. Empire and After. Philadelphia: University of Pennsylvania Press, 2013.

Buck, P. Lorraine. “'Justin Martyr's Apologies: Their Number, Destination, and Form.” JTS 54 (2003): 45-59.

Bull, Malcolm. "The Seventh-Day Adventists: Heretics of American Civil Religion." Sociology of Religion 50 (1989): 177-87.

Burke, Gary T. "Celsus and Justin: Carl Andresen Revisited.” ZNW 76 (1985): 107-16. 
Burrell, Barbara. Neokoroi: Greek Cities and Roman Emperors. Cincinnati Classical Studies, New Series. Vol. 9. Leiden; Boston: Brill, 2004.

Campenhausen, Hans von. Die Entstehung der christlichen Bibel. Tübingen: Mohr Siebeck, 1968.

Carlson, Donald H. Jewish-Christian Interpretation of the Pentateuch in the PseudoClementines. Minneapolis, MN: Fortress Press, 2013.

Chadwick, Henry. Early Christian Thought and the Classical Tradition: Studies in Justin, Clement, and Origen. Oxford; New York: Clarendon Press; Oxford University Press, 1984.

Champlin, Edward. Fronto and Antonine Rome. Cambridge, MA: Harvard University Press, 1980.

Cherubini, Beatrice. "Remarques sur le personnage Marcion dans l'interprétation de Justin

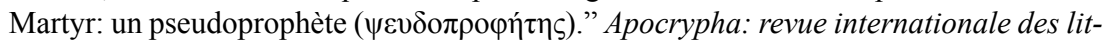
tératures apocryphes 22 (2011): 233-52.

Choi, Michael J. "What Is Christian Orthodoxy According to Justin's Dialogue?" SJT 63 (2010): 398-413.

Clark, Anna. Divine Qualities: Cult and Community in Republican Rome. Oxford Classical Monographs. Oxford; New York: Oxford University Press, 2007.

Cohen, Shaye J.D. "The Significance of Yavneh: Pharisees, Rabbis, and the End of Jewish Sectarianism." HUCA 55 (1984): 27-53.

. "A Virgin Defiled: Some Rabbinic and Christian Views on the Origins of Heresy." USQR 36 (1980): 1-11.

Conzelmann, Hans. Acts of the Apostles: A Commentary on the Acts of the Apostles. Hermeneia. Philadelphia: Fortress Press, 1987.

Coser, Lewis A. The Functions of Social Conflict. Glencoe, IL: Free Press, 1956.

Cosgrove, Charles H. "Justin Martyr and the Emerging Christian Canon: Observations on the Purpose and Destination of the Dialogue with Trypho." VC 36 (1982): 209-32.

Davids, Adelbert. "Justin Martyr on Monotheism and Heresy." Nederlands archief voor kerkgeschiedenis 56 (1975): 210-34.

DeConick, April D. The Original Gospel of Thomas in Translation. London; New York: T \& T Clark, 2007.

- Seek to See Him: Ascent and Vision Mysticism in the Gospel of Thomas. VC Supplements 33. Leiden; New York: Brill, 1996.

den Dulk, Matthijs. "Justin Martyr and the Authorship of the Earliest Anti-Heretical Treatise." $V C$, forthcoming.

_. " "One Would Not Consider Them Jews': Reassessing Jewish and Christian 'Heresy'." JECS, forthcoming. 549-59.

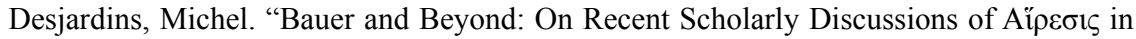
the Early Christian Era." Second Century 8 (1991): 65-82.

Des Places, Édouard, ed. Numénius: Fragments. Paris: Les Belles Lettres, 1973.

—. "Platonisme moyen et apologétique chrétienne au IIe siècle ap. J.-C.: Numénius, Atticus, Justin.” SP 15 (1984): 432-41.

Dillon, John M. Alcinous: The Handbook of Platonism. Oxford: Clarendon Press, 1995.

- The Middle Platonists, 80 B.C. to A.D. 220. Ithaca, NY: Cornell University Press, 1977. 
Dix, T. Keith. "Libraries, Private, Public (Greece and Rome)." In The Encyclopedia of Ancient History, edited by Roger S. Bagnall, Kai Brodersen, Craige Champion, Andrew Erskine, and Sabine Hübner, 4063-7. Malden, MA: Wiley-Blackwell, 2013.

Dix, T. Keith, and George W. Houston. "Public Libraries in the City of Rome from the Augustan Age to the Time of Diocletian." Mélanges de l'École Française de Rome 118 (2006): 671-717.

Donaldson, Terence L. “'We Gentiles': Ethnicity and Identity in Justin Martyr.” EC 4 (2013): 216-41.

Dortmund, Annette. Römisches Buchwesen um die Zeitenwende: War T. Pomponius Atticus (110-32 v. Chr.) Verleger? Wiesbaden: Harrassowitz, 2001.

Drijvers, Han J.W. "Adam and the True Prophet in the Pseudo-Clemetines." In Loyalitätskonflikte in der Religionsgeschichte: Festschrift für Carsten Colpe, edited by Christoph Elsas and Hans Gerhard Kippenberg, 314-23. Würzburg: Königshausen und Neumann, 1990.

Droge, Arthur J. Homer or Moses? Early Christian Interpretations of the History of Culture. HUTh 26. Tübingen: Mohr Siebeck, 1989.

Dubois, Jean-Daniel. "Le docétisme des christologies gnostiques revisité." NTS 63 (2017): 279-304.

Dunderberg, Ismo. Beyond Gnosticism: Myth, Lifestyle, and Society in the School of Valentinus. New York: Columbia University Press, 2008.

—. "The School of Valentinus." In A Companion to Second-Century Christian "Heretics," edited by Antti Marjanen and Petri Luomanen, 64-99. VC Supplements 76. Leiden; Boston: Brill, 2005.

Dunn, Geoffrey D. Tertullian's Aduersus Iudaeos: A Rhetorical Analysis. North American Patristics Society Patristic Monograph Series 19. Washington, DC: The Catholic University of America Press, 2008.

Easterling, Patricia E., and Bernard M.W. Knox. "Books and Readers in the Greek World." In The Cambridge History of Classical Literature, Vol. 1: Greek Literature, 1-41. Cambridge: Cambridge University Press, 1985.

Edwards, Mark J. “On the Platonic Schooling of Justin Martyr.” JTS 42 (1991): 17-34.

. "Simon Magus, the Bad Samaritan." In Portraits: Biographical Representation in the Greek and Latin Literature of the Roman Empire, edited by Mark J. Edwards and Simon Swain, 69-91. Oxford: Clarendon Press, 1997.

Efroymson, David. "The Patristic Connection." In Antisemitism and the Foundations of Christianity, edited by Alan T. Davies, 98-117. New York: Paulist Press, 1979.

Ehrman, Bart D. Lost Christianities: The Battle for Scripture and the Faiths We Never Knew. New York: Oxford University Press, 2003.

Emmel, Stephen. "The Gnostic Tradition in Relation to Greek Philosophy." In The Nag Hammadi Texts in the History of Religions, edited by Søren Giversen, Tage Petersen, and Jørgen Podemann Sørensen, 125-36. Copenhagen: Kongelige Danske Videnskabernes Selskab, 2002.

Eshel, Hanan. "The Bar Kochba Revolt, 132-135." In The Cambridge History of Judaism, Vol. 4: The Late Roman-Rabbinic Period, edited by Steven T. Katz, 105-27. Cambridge, UK; New York: Cambridge University Press, 2006.

Eshleman, Kendra. The Social World of Intellectuals in the Roman Empire: Sophists, Philosophers, and Christians. Greek Culture in the Roman World. Cambridge: Cambridge University Press, 2012.

Evans, Ernest. Adversus Marcionem. 2 vols. Oxford: Clarendon Press, 1972. 
Fantham, Elaine. Roman Literary Culture: From Plautus to Macrobius. Baltimore: The Johns Hopkins University Press, 2013.

Feldman, Louis H. "Pro-Jewish Intimations in Anti-Jewish Remarks Cited in Josephus' 'Against Apion'." JQR 78 (1988): 187-251.

Fossum, Jarl. "Gen. 1,26 and 2,7 in Judaism, Samaritanism, and Gnosticism.” JSJ 16 (1985): 202-39.

Frede, Michael. "Celsus' Attack on the Christians." In Philosophia Togata II: Plato and Aristotle at Rome, edited by Jonathan Barnes and Miriam Griffin, 218-40. Oxford: Oxford University Press, 1997.

Fredriksen, Paula. "What Parting of the Ways?" In The Ways That Never Parted: Jews and Christians in Late Antiquity and the Early Middle Ages, edited by Adam H. Becker and Annette Yoshiko Reed, 35-63. TSAJ 95. Tübingen: Mohr Siebeck, 2003.

Gamble, Harry Y. Books and Readers in the Early Church: A History of Early Christian Texts. New Haven: Yale University Press, 1995.

Gathercole, Simon J. The Composition of the Gospel of Thomas: Original Language and Influences. SNTSMS 151. Cambridge; New York: Cambridge University Press, 2012.

Georges, Tobias. "Justin's School in Rome: Reflections on Early Christian 'Schools'." ZAC 16 (2015): 75-87.

Gershenson, Daniel, and Gilles Quispel. "Meristae." VC 12 (1958): 19-26.

Glucker, John. Antiochus and the Late Academy. Hypomnemata 56. Göttingen: Vandenhoeck und Ruprecht, 1978.

Gold, Barbara K., ed. Literary and Artistic Patronage in Ancient Rome. Austin: University of Texas Press, 1982.

- Literary Patronage in Greece and Rome. Chapel Hill: University of North Carolina Press, 1987.

Goldfahn, Alex Heinrich “Justinus Martyr und die Agada." Monatsschrift für Geschichte und Wissenschaft des Judentums 22 (1873): 49-60, 104-15, 145-53, 194-202, 257-69.

Goodenough, Erwin R. The Theology of Justin Martyr. Jena: Frommann, 1923.

Goodman, Martin. Rome and Jerusalem: The Clash of Ancient Civilizations. New York: Alfred A. Knopf, 2007.

—. "Sadducees and Essenes after 70 CE." In Crossing the Boundaries: Essays in Biblical Interpretation in Honour of Michael D. Goulder, edited by Stanley E. Porter, Paul Joyce, and David E. Orton, 348-56. Biblical Interpretation 8. Leiden: Brill, 1994.

Goodspeed, Edgar J. Die ältesten Apologeten. Göttingen: Vandenhoeck \& Ruprecht, 1914.

Grant, Robert M. Gnosticism and Early Christianity. New York: Columbia University Press, 1959.

- Irenaeus of Lyons. The Early Church Fathers. London; New York: Routledge, 1997.

Gregory, Andrew F. The Reception of Luke and Acts in the Period before Irenaeus: Looking for Luke in the Second Century. WUNT 2.169. Tübingen: Mohr Siebeck, 2003.

Gregory, Andrew F., and C. Kavin Rowe, eds. Rethinking the Unity and Reception of Luke and Acts. Columbia, SC: University of South Carolina Press, 2010.

Grossberg, David M. Heresy and the Formation of the Rabbinic Community. TSAJ 168. Tübingen: Mohr Siebeck, 2017.

Haenchen, Ernst. The Acts of the Apostles: A Commentary. Philadelphia: Westminster Press, 1971.

Häkkinen, Sakari. "Ebionites." In A Companion to Second-Century Christian "Heretics, " edited by Antti Marjanen and Petri Luomanen, 247-78. Leiden; Boston: Brill, 2005. 
Hall, Jennifer. Lucian's Satire. Monographs in Classical Studies. New York: Arno Press, 1981.

Harnack, Adolf von. Die Altercatio Simonis Iudaei et Theophili Christiani nebst Untersuchungen über die antijüdische Polemik in der alten Kirche. TU 1.3. Leipzig: J.C. Hinrichs, 1883.

- Ist die Rede des Paulus in Athen ein ursprünglicher Bestandteil der Apostelgeschichte? Judentum und Judenchristentum in Justins Dialog mit Trypho, nebst einer Collation der Pariser Handschrift Nr. 450. TU 3.9.1. Leipzig: J.C. Hinrichs, 1913.

—. Zur Quellenkritik der Geschichte des Gnosticismus. Leipzig: E. Bidder, 1873.

Hayes, Andrew. Justin against Marcion: Defining the Christian Philosophy. Emerging Scholars. Minneapolis, MN: Fortress Press, 2017.

Hirshman, Marc G. A Rivalry of Genius: Jewish and Christian Biblical Interpretation in Late Antiquity. SUNY Series in Judaica. Albany: State University of New York Press, 1996.

Horbury, William. "Jewish-Christian Relations in Barnabas and Justin Martyr." In Jews and Christians: The Parting of the Ways, A.D. 70 to 135, edited by James D.G. Dunn, 315-46. WUNT 66. Tübingen: Mohr Siebeck, 1992.

Horner, Timothy J. "Listening to Trypho”: Justin Martyr's Dialogue Reconsidered. CBET 28. Leuven: Peeters, 2001.

Hout, Michel P.J. van den. A Commentary on the Letters of M. Cornelius Fronto. Leiden; Boston: Brill, 1999.

- ed. M. Cornelii Frontonis Epistulae. Bibliotheca scriptorum Graecorum et Romanorum Teubneriana. Leipzig: Teubner, 1988.

Hyldahl, Niels. Philosophie und Christentum: Eine Interpretation der Einleitung zum Dialog Justins. Acta theologica Danica 9. Kopenhagen: Munksgaard, 1966.

Iddeng, Jon W. "Publica Aut Peri! The Releasing and Distribution of Roman Books." Symbolae Osloenses 81 (2006): 58-84.

Inglebert, Hervé. Interpretatio christiana: Les mutations des savoirs (cosmographie, géographie, ethnographie, histoire) dans l'antiquité chrétienne (30-630 après J.C.) Paris: Institut d'études augustiniennes, 2001.

Iricinschi, Eduard, and Holger M. Zellentin. "Making Selves and Marking Others: Identity and Late Antique Heresiologies." In Heresy and Identity in Late Antiquity, edited by Eduard Iricinschi and Holger M. Zellentin, 1-27. TSAJ 119. Tübingen: Mohr Siebeck, 2008.

Jacobs, Andrew S. Christ Circumcised: A Study in Early Christian History and Difference. Divinations. Philadelphia: University of Pennsylvania Press, 2012.

Johnson, William A. Bookrolls and Scribes in Oxyrhynchus. Toronto; Buffalo: University of Toronto Press, 2004.

- Readers and Reading Culture in the High Roman Empire: A Study of Elite Communities. New York: Oxford University Press, 2010.

Joly, Robert. Christianisme et philosophie: Études sur Justin et les apologistes grecs du deuxième siècle. Bruxelles: Éditions de l'université de Bruxelles, 1973.

Kalvesmaki, Joel. The Theology of Arithmetic: Number Symbolism in Platonism and Early Christianity. Hellenic Studies 59. Washington, DC: Center for Hellenic Studies, 2013.

Kenyon, Frederic G. Books and Readers in Ancient Greece and Rome. Oxford: Clarendon Press, 1951.

King, Karen L. What Is Gnosticism? Cambridge, MA: Belknap, 2003. 
Kister, Menahem. "Some Early Jewish and Christian Exegetical Problems and the Dynamics of Monotheism." JSJ 37 (2006): 548-93.

Klawans, Jonathan. "Heresy without Orthodoxy: Josephus and the Rabbis on the Dangers of Illegitimate Jewish Beliefs." JJMJS 1 (2014): 99-126.

König, Jason, Aikaterini Oikonomopoulou, and Greg Woolf, eds. Ancient Libraries. Cambridge; New York: Cambridge University Press, 2013.

Kurtz, Lester R. “The Politics of Heresy.” AJS 88 (1983): 1085-115.

Lampe, Geoffrey W.H. A Patristic Greek Lexicon. Oxford: Clarendon Press, 1961.

Lampe, Peter. From Paul to Valentinus: Christians at Rome in the First Two Centuries. Minneapolis, MN: Fortress Press, 2003.

Le Boulluec, Alain. La notion d'hérésie dans la littérature grecque, IIe-IIIe siècles. Paris: Études augustiniennes, 1985.

Lieu, Judith M. "From Us but Not of Us? Moving the Boundaries of the Community." In Early Christian Communities between Ideal and Reality, edited by Mark Grundeken and Joseph Verheyden, 161-76. WUNT 342. Tübingen: Mohr Siebeck, 2015.

-Image and Reality: The Jews in the World of the Christians in the Second Century. Edinburgh: T \& T Clark, 1996.

- Marcion and the Making of a Heretic: God and Scripture in the Second Century. New York: Cambridge University Press, 2015.

- " "The Parting of the Ways': Theological Construct or Historical Reality?" JSNT 17 (1994): 101-19.

Lipsius, Richard Adelbert. "Ueber die ophitischen Systeme.” Zeitschrift für wissenschaftliche Theologie 6 (1863): 410-56.

. Zur Quellenkritik des Epiphanios. Wien: W. Braumüller, 1865.

Löhr, Winrich A. Basilides und seine Schule. Eine Studie zur Theologie- und Kirchengeschichte des zweiten Jahrhunderts. WUNT 83. Tübingen: Mohr Siebeck, 1996.

—. "Did Marcion Distinguish between a Just God and a Good God?" In Marcion und seine kirchengeschichtliche Wirkung = Marcion and his impact on church history: Vorträge der Internationalen Fachkonferenz zu Marcion, gehalten vom 15.-18. August 2001 in Mainz, edited by Gerhard May, Katharina Greschat, and Martin Meiser, 131-46. Berlin; New York: Walter de Gruyter, 2002.

Lotz, John-Paul. Ignatius and Concord: The Background and Use of the Language of Concord in the Letters of Ignatius of Antioch. Patristic Studies 8. New York: Peter Lang, 2007.

Louis, Pierre. Albinos épitomé. Paris: Les Belles Lettres, 1945.

Lüdemann, Gerd. Heretics: The Other Side of Early Christianity. Louisville, KY: Westminster John Knox Press, 1996.

_. "Zur Geschichte des ältesten Christentums in Rom. I. Valentin und Marcion. II. Ptolemäus und Justin." ZNW 70 (1979): 86-114.

Luttikhuizen, Gerard P. "The Creation of Man and Woman in the Secret Book of John." In The Creation of Man and Woman: Interpretations of the Biblical Narratives in Jewish and Christian Traditions, edited by Gerard P. Luttikhuizen, 140-55. TBN 3. Leiden; Boston: Brill, 2000.

Lyman, J. Rebecca. "2002 NAPS Presidential Address: Hellenism and Heresy.” JECS 11 (2003): 209-22.

_. "The Politics of Passing: Justin Martyr's Conversion as a Problem of 'Hellenization'." In Conversion in Late Antiquity and the Early Middle Ages: Seeing and Believing, 
edited by Kenneth Mills and Anthony Grafton, 36-60. Studies in Comparative History. Rochester, NY: University of Rochester Press, 2003.

Mach, Michael. "Justin Martyr's Dialogus cum Tryphone Iudaeo and the Development of Christian Anti-Judaism." In Contra Iudaeos: Ancient and Medieval Polemics between Christians and Jews, edited by Ora Limor and Guy G. Stroumsa, 27-47. Tübingen: Mohr Siebeck, 1996.

MacLennan, Robert S. Early Christian Texts on Jews and Judaism. Brown Judaic Studies 194. Atlanta, GA: Scholars Press, 1990.

Maier, Harry O. "The Politics and Rhetoric of Discord and Concord in Paul and Ignatius." In Trajectories through the New Testament and the Apostolic Fathers, edited by Andrew Gregory and Christopher Tuckett, 307-24. Oxford: Oxford University Press, 2007.

Manns, Frédéric. "Les Pseudo-Clémentines ('Homélies' et 'Reconnaissances'): état de la question." Liber Annuus 53 (2003): 157-84.

Marcovich, Miroslav. Dialogus cum Tryphone. PTS 47. Berlin; New York: Walter de Gruyter, 1997.

. Iustini Martyris apologiae pro Christianis. PTS 38. Berlin; New York: Walter de Gruyter, 1994.

Markschies, Christoph. Kaiserzeitliche christliche Theologie und ihre Institutionen: Prolegomena zu einer Geschichte der antiken christlichen Theologie. Tübingen: Mohr Siebeck, 2007.

. "Lehrer, Schüler, Schule: Zur Bedeutung einer Institution für das Antike Christentum." In Religiöse Vereine in der römischen Antike: Untersuchungen zu Organisation, Ritual und Raumordnung, edited by Ulrike Egelhaaf-Gaiser and Alfred Schäfer, 97-120. STAC 13. Tübingen: Mohr Siebeck, 2002.

—. "New Research on Ptolemaeus Gnosticus." ZAC 4 (2000): 225-54.

- Valentinus Gnosticus? Untersuchungen zur valentinianischen Gnosis mit einem Kommentar zu den Fragmenten Valentins. WUNT 65. Tübingen: Mohr Siebeck, 1992.

Martin, Dale B. The Corinthian Body. New Haven: Yale University Press, 1995.

Mason, Steve. Life of Josephus. Flavius Josephus: Translation and Commentary. Vol. 9. Leiden; Boston: Brill, 2001.

Massaux, Édouard. The Influence of the Gospel of Saint Matthew on Christian Literature before Saint Irenaeus, Vol. 3: The Apologists and the Didache. Macon, GA: Mercer University Press, 1990.

Meyboom, Hajo U. "Marcion en Paulus in de Clementijnen." Theologisch Tijdschrift 25 (1891): 1-46.

Millar, Fergus. The Emperor in the Roman World, 31 BC-AD 337. Ithaca, NY: Cornell University Press, 1977.

Minns, Denis, and Paul Parvis. Justin, Philosopher and Martyr: Apologies. Oxford Early Christian Texts. Oxford; New York: Oxford University Press, 2009.

Misiarczyk, Leszek. Il midrash nel Dialogo con Trifone di Giustino martire. Płock: Płocki instytut wydawniczy, 1999.

Mitchell, Margaret M. Paul and the Rhetoric of Reconciliation: An Exegetical Investigation of the Language and Composition of 1 Corinthians. Tübingen: Mohr Siebeck, 1991.

Moll, Sebastian. The Arch-Heretic Marcion. WUNT 250. Tübingen: Mohr Siebeck, 2010.

- "Justin and the Pontic Wolf." In Justin Martyr and His Worlds, edited by Sara Parvis and Paul Foster, 145-51. Minneapolis, MN: Fortress Press, 2007.

Mouritsen, Henrik. The Freedman in the Roman World. Cambridge; New York: Cambridge University Press, 2011. 
Munier, Charles. “À propos d'une édition récente des Apologies de Justin.” Revue des Sciences Religieuses 71 (1997): 299-309.

- Saint Justin: Apologie pour les chrétiens: édition et traduction. Fribourg, Suisse: Éditions universitaires, 1995.

Nautin, Pierre. "Conférence de M. Pierre Nautin." École pratique des hautes études, Section des sciences religieuses. Annuaire 90 (1981): 335-40.

Neymeyr, Ulrich. Die christlichen Lehrer im zweiten Jahrhundert: Ihre Lehrtätigkeit, ihr Selbstverständnis und ihre Geschichte. VC Supplements 4. Leiden; New York: Brill, 1989.

Nickelsburg, George W.E. Resurrection, Immortality, and Eternal Life in Intertestamental Judaism and Early Christianity. Cambridge, MA: Harvard University Press, 2006.

Niese, Benedikt. Flavii Iosephi opera. Reprinted edition 1955. Berlin: Weidmann, 1895.

Norelli, Enrico. "Marcione e la costruzione dell'eresia come fenomeno universale in Giustino Martire." Rivista di storia del cristianesimo 6 (2009): 363-88.

—. "Un 'Dieu bon' agressif et haineux ? Le Marcion discutable de Sebastian Moll." JEH 65 (2014): 347-53.

O'Brien, Carl Séan. The Demiurge in Ancient Thought: Secondary Gods and Divine Mediators. Cambridge: Cambridge University Press, 2015.

Osborn, Eric Francis. Justin Martyr. BHTh 47. Tübingen: Mohr Siebeck, 1973.

Otranto, Giorgio. Esegesi biblica e storia in Giustino: (dial. 63-64). Bari: Istituto di letteratura cristiana antica-Università, 1979.

Overbeck, Franz. "Über die Anfänge der patristischen Literatur." Historische Zeitschrift 48 (1882): 417-72.

Pagels, Elaine. 'Irenaeus, the 'Canon of Truth', and the 'Gospel of John': 'Making a Difference' through Hermeneutics and Ritual.” VC 56 (2002): 339-71.

Parsons, Mikeal C., and Richard I. Pervo. Rethinking the Unity of Luke and Acts. Minneapolis: Fortress Press, 1993.

Parvis, Paul. "Justin, Philosopher and Martyr: The Posthumous Creation of the Second Apology." In Justin Martyr and His Worlds, edited by Sara Parvis and Paul Foster, 22-37. Minneapolis, MN: Fortress Press, 2007.

Parvis, Sara. "Justin Martyr and the Apologetic Tradition." In Justin Martyr and His Worlds, edited by Sara Parvis and Paul Foster, 115-27. Minneapolis, MN: Fortress Press, 2007.

Pearson, Birger A. Ancient Gnosticism: Traditions and Literature. Minneapolis, MN: Fortress Press, 2007.

Pervo, Richard I. Acts: A Commentary. Hermeneia. Minneapolis, MN: Fortress Press, 2009. . Dating Acts: Between the Evangelists and the Apologists. Santa Rosa, CA: Polebridge Press, 2006.

- The Making of Paul: Constructions of the Apostle in Early Christianity. Minneapolis, MN: Fortress Press, 2010.

Petit, Françoise. Quaestiones in Genesim et in Exodum: fragmenta Graeca. Les œuvres de Philon d'Alexandrie 33. Paris: Éditions du Cerf, 1978.

Pétrement, Simone. A Separate God: The Origins and Teachings of Gnosticism. San Francisco: Harper, 1993.

Pouderon, Bernard. Athénagore d'Athènes, philosophe chrétien. Théologie historique 82. Paris: Beauchesne, 1989.

Prigent, Pierre. Justin et l'Ancien testament: l'argumentation scripturaire du traité de Justin contre toutes les hérésies comme source principale du Dialogue avec Tryphon et de la première Apologie. Paris: Librairie Lecoffre, 1964. 
Quispel, Gilles. De bronnen van Tertullianus'Adversus Marcionem. Leiden: Burgersdijk \& Niermans, 1943.

Räisänen, Heikki. "Marcion and the Origins of Christian Anti-Judaism: A Reappraisal." Temenos 33 (1997): 121-35.

Rajak, Tessa. "Talking at Trypho: Christian Apologetic as Anti-Judaism in Justin's 'Dialogue with Trypho the Jew'." In Apologetics in the Roman Empire: Pagans, Jews, and Christians, edited by Mark J. Edwards, Martin Goodman, Simon Price, and Christopher Rowland, 59-80. Oxford: Oxford University Press, 1999.

Rehm, Bernhard, Johannes Irmscher, and Georg Strecker. Die Pseudoklementinen. I. Homilien. GCS. Berlin: Akademie-Verlag, 1992.

Remus, Harold. "Justin Martyr's Argument with Judaism." In Separation and Polemic, edited by Stephen Wilson, 59-80. Waterloo, Ontario: Wilfrid Laurier University Press, 1986.

Reydams-Schils, Gretchen J. Demiurge and Providence: Stoic and Platonist Readings of Plato’s Timaeus. Monothéismes et Philosophie. Turnhout: Brepols, 1999.

Rijksbaron, Albert. The Syntax and Semantics of the Verb in Classical Greek. Chicago: University of Chicago Press, 2006.

Rokeah, David. Justin Martyr and the Jews. JCP 5. Leiden; Boston: Brill, 2002.

Ross, William D. Aristotelis politica. Scriptorum classicorum bibliotheca Oxoniensis. Oxford: Clarendon Press, 1957.

Rothschild, Clare K. Luke-Acts and the Rhetoric of History: An Investigation of Early Christian Historiography. WUNT 2.175. Tübingen: Mohr Siebeck, 2004.

Rousseau, Adelin, and Louis Doutreleau. Irenée de Lyon: Contre les hérésies (Livre I, Tome II). SC 264. Paris: Éditions du Cerf, 1979.

Rowe, C. Kavin. "History, Hermeneutics, and the Unity of Luke-Acts." JSNT 28 (2005): 131-57.

Royalty, Robert M. "Justin's Conversion and the Rhetoric of Heresy.” In Studia Patristica. Vol. 40, edited by Frances M. Young, Mark J. Edwards, and Paul Parvis, 509-14. Leuven: Peeters, 2006.

- The Origin of Heresy: A History of Discourse in Second Temple Judaism and Early Christianity. Routledge Studies in Religion 18. New York: Routledge, 2013.

Rudolph, Anette. "Denn wir sind jenes Volk ..." Die neue Gottesverehrung in Justins Dialogue mit dem Juden Tryphon in historisch-theologischer Sicht. Hereditas: Studien zur Alten Kirchengeschichte. Bonn: Borengässer, 1999.

Runia, David T. Philo of Alexandria and the Timaeus of Plato. Philosophia Antiqua 44. Leiden: Brill, 1986.

—. " “Where, Tell Me, Is the Jew...?' Basil, Philo and Isidore of Pelusium.” VC 46 (1992): 172-89.

Sagnard, François M.M. "Y a-t-il un plan du Dialogue avec Tryphon?” In Mélanges Joseph de Ghellinck, S.J., 1:171-82. Gembloux: Duculot, 1951.

Salles, A. "Simon le Magicien ou Marcion?" VC 12 (1958): 197-224.

Schmeller, Thomas. Schulen im Neuen Testament? Zur Stellung des Urchristentums in der Bildungswelt seiner Zeit. Herders biblische Studien 30. Freiburg; New York: Herder, 2001 .

Schoedel, William R. "Apologetic Literature and Ambassadorial Activities." HTR 82 (1989): 55-78.

Schoeps, Hans Joachim. Jewish Christianity: Factional Disputes in the Early Church. Philadelphia: Fortress Press, 1969. 
Theologie und Geschichte des Judenchristentums. Tübingen: Mohr Siebeck, 1949.

Scholten, Clemens. "Die Funktion der Häresienabwehr in der Alten Kirche." VC 66 (2012): 229-68.

—. "Zum Herkunftsort des Simon Magus." VC 69 (2015): 534-41.

Schremer, Adiel. "Midrash, Theology, and History: Two Powers in Heaven Revisited." JSJ 39 (2008): 234-9.

- Brothers Estranged: Heresy, Christianity, and Jewish Identity in Late Antiquity. Oxford; New York: Oxford University Press, 2010.

Schubart, Wilhelm. Das Buch bei den Griechen und Römern. Heidelberg: Lambert Schneider, 1962.

Schwartz, Seth. Imperialism and Jewish Society 200 B.C.E. to 640 C.E. Princeton: Princeton University Press, 2001.

Setzer, Claudia J. Jewish Responses to Early Christians: History and Polemics, 30-150 C.E. Minneapolis: Fortress Press, 1994.

Shotwell, Willis A. The Biblical Exegesis of Justin Martyr. London: S.P.C.K., 1965.

Shuve, Karl. "The Doctrine of the False Pericopes and Other Late Antique Approaches to the Problem of Scripture's Unity." In Nouvelles intrigues pseudo-clementines = Plots in the Pseudo-Clementine romance: actes du deuxième colloque international sur la litterature apocryphe chrétienne, Lausanne-Genève, 30 août-2 septembre 2006, edited by Frédéric Amsler, Albert Frey, Charlotte Touati, and René Girardet, 437-45. Prahins: Éditions du Zèbre, 2008.

Sigal, Phillip. "An Inquiry into Aspects of Judaism in Justin's Dialogue with Trypho." AbrNahrain 18 (1979): 74-100.

Simon, Marcel. "From Greek Hairesis to Christian Heresy." In Early Christian Literature and the Classical Intellectual Tradition: In Honorem Robert M. Grant, edited by William R. Schoedel and Robert L. Wilken, 101-16. Paris: Éditions Beauchesne, 1979.

- Jewish Sects at the Time of Jesus. Philadelphia: Fortress Press, 1967.

Skarsaune, Oskar. "The Conversion of Justin Martyr." Studia Theologica 30 (1976): 53-73. . "The Development of Scriptural Interpretation in the Second and Third Centuries." In Hebrew Bible/Old Testament: The History of Its Interpretation I/1: Antiquity, edited by Magne Sæbø, 373-442. Göttingen: Vandenhoeck \& Ruprecht, 1996.

- The Proof from Prophecy: A Study in Justin Martyr's Proof-Text Tradition: TextType, Provenance, Theological Profile. NovT Supplements 56. Leiden: Brill, 1987.

Smith, Geoffrey S. Guilt by Association: Heresy Catalogues in Early Christianity. Oxford; New York: Oxford University Press, 2015.

Smith, Jonathan Z. "What a Difference a Difference Makes." In "To See Ourselves as Others See Us": Christians, Jews, "Others" in Late Antiquity, edited by Jacob Neusner, Ernest S. Frerichs, and Caroline McCracken-Flesher, 3-48. Chico, CA: Scholars Press, 1985.

Smyth, Herbert Weir. Greek Grammar. Cambridge, MA: Harvard University Press, 1956.

Snyder, Harlow Gregory. " 'Above the Bath of Myrtinus': Justin Martyr's 'School' in the City of Rome." HTR 100 (2007): 335-62.

Stanton, Graham. "'God-Fearers': Neglected Evidence in Justin Martyr's Dialogue with Trypho." In Studies in Matthew and Early Christianity, edited by Markus N.A. Bockmuehl and David Lincicum, 351-62. WUNT 309. Tübingen: Mohr Siebeck, 2013.

Stark, Rodney. The Rise of Christianity: A Sociologist Reconsiders History. Princeton, NJ: Princeton University Press, 1996.

Starr, Raymond. "The Circulation of Literary Texts in the Roman World." CQ 37 (1987): 213-23. 
Sterling, Gregory E. Historiography and Self-Definition: Josephos, Luke-Acts, and Apologetic Historiography. NovT Supplements 64. Leiden; New York: Brill, 1992.

Stylianopoulos, Theodore G. Justin Martyr and the Mosaic Law. Dissertation Series 20. Missoula, MT: Society of Biblical Literature; Scholars Press, 1975.

Talbert, Charles H. Reading Acts: A Literary and Theological Commentary on the Acts of the Apostles. Rev. ed. Reading the New Testament. Macon, GA: Smyth \& Helwys, 2005.

Taylor, Joan E. The Essenes, the Scrolls, and the Dead Sea. Oxford: Oxford University Press, 2012.

Tcherikover, Victor. “Jewish Apologetic Literature Reconsidered.” Eos 48 (1956): 169-93.

Tell, Håkan. Plato’s Counterfeit Sophists. Washington, DC; Cambridge, MA: Center for Hellenic Studies, 2011.

Thériault, Gaétan. Le culte d'homonoia dans les cités grecques. Lyon; Québec: Maison de l'Orient méditerranéen; Éditions du Sphinx, 1996.

Thomassen, Einar. "Orthodoxy and Heresy in Second-Century Rome." HTR 97 (2004): 241-56.

- The Spiritual Seed: The Church of the "Valentinians." Nag Hammadi and Manichaean Studies. Vol. 60. Leiden; Boston: Brill, 2006.

"What Is Heresy, and Why Did It Matter?" In Invention, Rewriting, Usurpation: Discursive Fights over Religious Traditions in Antiquity, edited by Jörg Ulrich, AndersChristian Jacobsen, and David Brakke, 191-201. Frankfurt am Main: Lang, 2012.

Thompson, Alan J. One Lord, One People: The Unity of the Church in Acts in Its Literary Setting. LNTS 359. London: T \& T Clark, 2008.

Thorsteinsson, Runar M. "By Philosophy Alone: Reassessing Justin's Christianity and His Turn from Platonism." EC 3 (2012): 492-517.

Trakatellis, Demetrios. “Justin Martyr's Trypho.” HTR 79 (1986): 287-97.

Trelenberg, Jörg. Oratio ad Graecos $=$ Rede an die Griechen. BHTh 165. Tübingen: Mohr Siebeck, 2012.

Tröger, Karl-Wolfgang. "Doketistische Christologie in Nag-Hammadi-Texten. Ein Beitrag zum Doketismus in frühchristlicher Zeit." Kairos 19 (1977): 45-52.

Turner, Eric G. Greek Papyri: An Introduction. Princeton, NJ: Princeton University Press, 1968.

Turner, John D. Sethian Gnosticism and the Platonic Tradition. Sainte-Foy, Quebec: Presses de l'Université Laval, 2001.

Tyson, Joseph B. "Anti-Judaism in Marcion and His Opponents." Studies in ChristianJewish Relations 1 (2005-2006): 196-208.

Ulrich, Jörg. “What Do We Know about Justin's ‘School' in Rome?” ZAC 16 (2015): 62-74.

Van Winden, Jacobus C.M. An Early Christian Philosopher: Justin Martyr's Dialogue with Trypho, Chapters One to Nine. Philosophia patrum 1. Leiden: Brill, 1971.

Verwijs, Pieter Gotfried. Evangelium und neues Gesetz in der ältesten Christenheit bis auf Marcion. Utrecht: Kemink, 1960.

Vööbus, Arthur. The Didascalia Apostolorum in Syriac. CSCO 408. Vol. 2. Louvain: Secrétariat du CorpusSCO, 1979.

Voss, Bernd Reiner. Der Dialog in der frühchristlichen Literatur. München: W. Fink, 1970.

Wallraff, Martin. Kodex und Kanon: Das Buch im frühen Christentum. Hans-LietzmannVorlesungen 12. Berlin: Walter de Gruyter, 2013.

Wanke, Daniel. "Irenäus und die Häretiker in Rom." ZAC 3 (1999): 202-40.

Welborn, Laurence L. "On the Discord in Corinth: 1 Corinthians 1-4 and Ancient Politics." JBL 106 (1987): 85-111. 
Wendel, Susan J. Scriptural Interpretation and Community Self-Definition in Luke-Acts and the Writings of Justin Martyr. NovT Supplements 139. Leiden; Boston: Brill, 2011.

Wevers, John William. Text History of the Greek Genesis. Göttingen: Vandenhoeck \& Ruprecht, 1974.

White, Peter. "Amicitia and the Profession of Poetry in Early Imperial Rome." JRS 68 (1978): 74-92.

Whittaker, John. "Platonic Philosophy in the Early Centuries of the Empire." In $A N R W$, 2.36.1: 81-123. Berlin: Walter de Gruyter, 1987.

Wilhite, David E. "Was Marcion a Docetist? The Body of Evidence vs. Tertullian's Argument." VC 71 (2017): 1-36.

Williams, A. Lukyn. Justin Martyr, the Dialogue with Trypho. London; New York: S.P.C.K.; Macmillan, 1930.

Williams, Michael Allen. Rethinking “Gnosticism”: An Argument for Dismantling a Dubious Category. Princeton, NJ: Princeton University Press, 1996.

Wilson, Robin McL. "The Early History of the Exegesis of Gen 1:26." In Studia Patristica I, 433-7. Berlin: Akademie-Verlag, 1957.

Wilson, Stephen G. "Marcion and the Jews." In Anti-Judaism in Early Christianity, Vol. 2: Separation and Polemic, edited by Stephen G. Wilson, 45-58. Waterloo, Ontario: Wilfrid Laurier University Press, 1986.

- Related Strangers: Jews and Christians, 70-170 C.E. Minneapolis, MN: Fortress Press, 1995.

Winsbury, Rex. The Roman Book: Books, Publishing and Performance in Classical Rome. London: Duckworth, 2009.

Wisse, Frederick. "The 'Opponents' in the New Testament in Light of the Nag Hammadi Writings." In Colloque international sur les textes de Nag Hammadi, Québec, 22-25 août, 1978, edited by Bernard Barc, 99-120. Québec: Les Presses de l'Université Laval, 1981.

Youtie, Herbert C. “АГРАММАТО : An Aspect of Greek Society in Egypt." Harvard Studies in Classical Philology 75 (1971): 161-76.

Zahn, Theodor. "Studien zu Justinus Martyr." ZKG 8 (1886): 1-84.

Zito, George V. "Toward a Sociology of Heresy." SA 44 (1983): 123-30.

Zugmann, Michael. "Hellenisten" in der Apostelgeschichte. WUNT 2.264. Tübingen: Mohr Siebeck, 2009. 
$\because$ Taylor \& Francis Taylor \& Francis Group http://taylorandfrancis.com 


\section{INDEX}

Acts of the Apostles 8, 100, 113, 143, 145-154

Adelbert, Richard 32n34

Adversus Haereses (Irenaeus) 53, see also Irenaeus

Adversus Marcionem (Tertullian) 59, 140 , see also Tertullian

Against Apion (Josephus) 100-102, $125 \mathrm{n} 34$, see also Josephus

Alcinous 21, 34n39

Alexander, Loveday 47n11

Allert, Craig D. 9n9, 11n23, 46n4, 48n14

Andresen, Carl 126n46

angels 115-117, 136n121

anthropogony $115-117,135 \mathrm{n} 120$

apologetic literature, other 100-102; see also Dialogue with Trypho; First Apology

Archambault, Georges 126n58

Aristotle 1, 28n16

Arnal, William E. 127n62

atheism/atheists 15, 16, 22-23, 26, 35n54, 95-96, 109, 140

Athenagoras 101-102, 125n40

Baarda, Tjitze 129n77

Bagnall, Roger S. 49n34

Baptists 111, 113, 133n106

Barclay, John 125n36

Bakke, Odd Magne 138n137

Bar Kochba revolt 7, 69, 81-83, 86, 91n55, 92n57, 105, 142

Barnard, Leslie W. 11n26, 31n31, 111, 130n88, 130n89, 134n113

Barrett, Charles Kingsley 153n2

Basilides 116

Basilidians 4, 36n67, 95, 117

Bauer, Walter 5n4, 119, 138n113
Becker, Adam H. 8n3

Berlinerblau, Jacques 127n62

Betz, Hans Dieter 138n134

biblical prophecy $52,69,75-78,86,87$, 106-108, 128n73, 143, 149

Bikerman, Elias 132n101

Birt, Theodor 49n28

Black, Matthew 129n81

blasphemy $4,7,19,25,55,62,71,80-81$, 95-96, 103, 142

Bobichon, Philippe 10n12, 10n13, 11n22, 46n4, 48n14, 48n22, 48n24, 65n16, 66n24, 88n2, 89n3, 93n73, 95n75, 130n88, 132n103, 134n111, 134n113

Bokser, Ben Zion 89n3

booksellers 43

Bowersock, Glen 33n37

Boyarin, Daniel viii, $8 \mathrm{n} 2,9 \mathrm{n} 7,9 \mathrm{n} 9,11 \mathrm{n} 24$, 48n16, 110-114, 125n36, 128n76, 129n77, 129n78, 129n81, 129n82, 130n86, 130n90, 130n91, 131n94, 132n105, 135n114, 137n125, 137n126

Boys-Stones, George R. 128n71

Brakke, David viii, 11 n24

Brehm, H. Alan 130n84

Brent, Allen 97, 123n14

Broek, Roel van den 135n120

Bruun, Christer 46n8

Bryen, Ari Z. 29n20

Buck, P. Lorraine 27n6

Bull, Malcolm 127n62

Burke, Gary T. 126n46

Burrell, Barbara 33n37

Campenhausen, Hans von, 54, 64n6

Carlson, Donald H. 35n50

Carpocrates 37n67, 116

Carpocratians 122n8 
Celsus $31 n 28,40 n 42,102,126 n 46$, $126 \mathrm{n} 47,129 \mathrm{n} 81$

Chadwick, Henry 126n46

Champlin, Edward 29n23

Cherubini, Beatrice 33n35

Choi, Michael J. 134n113

Christian audience, for Dialogue 5-7, 40-45, 52, 118-120, 140-143

Christian demiurgists see demiurgical Christians

Christian identity 2, 3, 8, 139

Christianity $10 \mathrm{n} 19$; formation of $1-2,139$; internal debates and conflict within 7-8, 69, 81-83, 87-88, 96-102, 118-120, 139; Judaism and 1, 87-88, 139; rival theologies within 54-62; study of 1

Christians: divisions among 15-16, 96-102, 105-121, 118-120; heresies among 95-121, 142; persecution of early 5, 79-80, 151-152; public perceptions of, as criminals 15,16 ; "so-called" 17-19, 23, 25, 36n66, 96, 102, 106, 109, 117; see also demiurgical Christians, heretics

Christian unity 97-102, 106, 122n12

Cicero $125 \mathrm{n} 36$

circumcision $47 \mathrm{n} 12,53,55,56,65 \mathrm{n} 15,82$, $134 \mathrm{n} 10$

Clark, Anna 123n16

Cohen, Shaye J.D. 111, 130n90, 131n95

Conzelmann, Hans 153n4

Coser, Lewis A. 127n62

Cosgrove, Charles H. 11n27, 41, 46n4, $48 \mathrm{n} 21$

creation 114-117, 135n120, 136n121

Creator 21, 60, 72, 140

crucifixion 73

Davids, Adelbert 36n60

Davies, Alan T. 64n11

DeConick, April D. 129n77, 135n118

Demiurge 4, 21-26, 30n26, 34n46, 37n68, $52,139,140$

demiurgical Christians 4-7, 13, 21-26, 36n67, 52-53, 57, 140-141; break from Jewish God by 81-83, 139; Dialogue as response to $5,52-68,140-144$; heresiology and 102-105; heresy of 95-96, 118-120, 139-140, 144; on Jesus and Jewish Scriptures 57-58, 75-76, 88; philosophy and 84-85 demons 22, 26

den Dulk, Matthijs 9n7, 36n58, 128n76, 132n97

Desjardins, Michel 132n97

Des Places, Édouard 34n43

Dialogue with Trypho (Justin Martyr) 1-2, 109-114; anti-demiurgical aspects of 5, 52-68, 140-144; as antiheretical text 52-68, 69, 74-76, 95-97, 139-140; audience for 5-7, 38-53, 56, 60-62, 71-72, 76-79, 97, 102,

118-121, 140-143; composition of 69-94; content of 3-4; context of 7, 74-76, 81-83; Dialogue 62 114-118; Dialogue 80 42-43; discussion of Christian heresies in 95-121; ending of 69-74, 77-79, 87, 88n1; internal concerns in 54-62; literary setting of $81-83,86,142$; philosophy in $83-86$; production of 43-45; refiguring of 2-8; rhetorical aims of 118-120; structure of $3,6,10 \mathrm{n} 13,63 \mathrm{n} 1,69,73-74$; traditional reading of 2-3

Dillon, John M 34n40

Dio Chrysostom 97, 98

dissent 97-102, 105-119, 121, 142-143

divine punishment 17

Dix, T. Keith 49n36, 50n38

Donaldson, Terence L. 90n31

Dortmund, Annette 49n28

Drijvers, Han J.W. 35n50

Droge, Arthur J. 34n43

Dubois, Jean-Daniel 68n48

Dunderberg, Ismo 67n37, 136n121

Dunn, Geoffrey D. $5 \ln 50$

Dunn, James D.G. 154n15

Easterling, Patricia E. 49n28

Ebionites 25

Edwards, Mark J. 32n31, 92n58

Efroymson, David 64n11

Egyptians 100-101

Ehrman, Bart D. 9n11

Elsas, Christoph 35n50

Embassy (Athenagoras) 101-102

Emmel, Stephen 93n68

Encratites 25

Epicureans 99

Eric G. Turner, 49n28

Eshel, Hanan 92n55

Eshleman, Kendra 31n30, 128n71

Essenes 133n106 
Eusebius 30n26, 31n28, 35n56, 37n67, 99, $110,111,122 n 7,122 n 8,133 n 106,154 n 15$

Evans, Ernest 66n21

Falls, Thomas B. 11n 22

false prophets 33n35, 61, 93n69, 107, 109

Fantham, Elaine 46n9

Feldman, Louis H. 125n35

Felix, Minucius 18, 29n24

First Apology (Justin Martyr) 5, 12n31, 13-23, 26, 139; 1 Apol. 4 and 7 14-16; 1 Apol. 16 16-18; 1 Apol. 26 and 56-58, 18-23; audience for 14; format of 13-14

"First God" 21-22, 33n37, 34n46

Fossum, Jarl 135n115

Foster, Paul 26n2, 27n6, 125n39

Fourth Philosophy 137n128

Francis, Eric 26n1

Frede, Michael 128n71

Fredriksen, Paula 8n3, 92n55

Fronto, M. Cornelius 18

Galileans 110, 113, 133n106

Gamble, Harry Y. 44, 46n9, 49-50

Gathercole, Simon J. 129n77

Genesis 116, 136n122

genistae $110,113,128 \mathrm{n} 77$

Georges, Tobias 50n46

Gershenson, Daniel 128n77

Glucker, John 122n4

Gnosticism 11n24

God: Bar Kochba revolt and 81-83; character of 56-59; Creator 21, 60, 72, 140; existence of other 60; First God 21-22, 33n37, 34n46; inconsistency of 57; Jesus and 60, 72-73, 75-76, 114-115; Jewish 4, 6, 13, 21, 26, 53, 57-58, 63, 82-83, 86, 92n57, 103, 120; Supreme Being 21, 22, 25, 26, 30n26, 85,142

Gold, Barbara K. 46n9

Goldfahn, Alex Heinrich 132n98

Goodenough, Erwin R. 10n16

Goodman, Martin 92n55, 130n88

Goodspeed, Edgar J. 9n11, 10n22, 66n24, $88 \mathrm{n} 2,126 \mathrm{n} 54,127 \mathrm{n} 69,128 \mathrm{n} 74$

Gospel of Luke 145

Grafton, Anthony26n4

Grant, Robert M. 92n57, 153n1

Greco-Roman philosophy 3, 7, 38, 83-86, $102,106,108-109,142$

Gregory, Andrew F. 146, 138n137
Grossberg, David M. 131n95

Grundeken, Mark 9n7

Haenchen, Ernst 145-146, 149, 153n4

Häkkinen, Sakari, 36n62

hairesis 8, 109-117, 121, 124n33, 130n93, $132 \mathrm{n} 97,143,150-151$

Hall, Jennifer 28n15

Halton, Thomas P. $11 \mathrm{n} 22$

Harnack, Adolf von 11n29, 32n35, 36n62, 36n63, 37n67, 38, 46n1, 129n83, $13 \ln 93,133 n 106$

Hayes, Andrew 9n9, 92n58

Hegesippus $31 \mathrm{n} 28$, 36n63, 36n67, 110-11, $122 \mathrm{n} 8,133 \mathrm{n} 106$

Helen 18, 19, 21, 24

Hellenians 110-111, 113, 130n85

Hellenism 26n4, 38, 84

Herculaneum library 44

heresiology 7-8, 95-138, 143;

conversation with Trypho and 102-105; internal audience and 118-120; Jewish 109-118; problem of dissent and $105-118$

heresy 7-8, 26, 106; Christian 95-121, 142; concept of 118, 121, 143; Dialogue as aimed against $52-68,69,74-76$, 139-140; as fulfillment of prophecy 106-108; history of 2; Jewish 8, 96-97, 109-118, 133n106, 143

heretics 7, 13, 103; commonalities among 95-96; demiurgical Christians as 118-120, 139-140, 144; in First Apology 14-23, 36n67; influence of 80-81; as "other" 106; punishment of 17-18

Hirshman, Marc G. 132n99

homonoia 97-98, 99, 101, see also unity

Horbury, William 154n15

Horner, Timothy J. 9n5, 9n11, 88n1, 89n3, 89n7, 89n15, 90n24, 91n40

Houston, George W. 49n36

Hout, Michel P.J. van den 29n23

human body, creation of 115-117, $135 \mathrm{n} 120,136 \mathrm{n} 121$

Hyldahl, Niels 46n3, 92n59

Iddeng, Jon W. 49n31

idol meat 80-81, 103, 106-107, 120, 142

impiety $14,15,19,29 \mathrm{n} 21$

Inglebert, Hervé $3 \ln 30$

Irenaeus 10n1121-22, 24-25, 26, 53, 57, $68 \mathrm{n} 48,117,140,149$ 
Iricinschi, Eduard 9n7, 117, 137n127

Irmscher, Johannes 122n12

Jacobs, Andrew S. 9n11

Jerusalem 82, 83, 105

Jesus: birth of 68n49; in First Apology 16-17; followers of 1, 4; God and 60, 72-73, 75-76, 114-115; Jewish Scriptures and 6, 75-76, 88, 104, 140, 141; as Messiah $5,6,53,75-77,86$; name change of 74 ; recognition of, by Jews 75-79; suffering of $61,68 \mathrm{n} 49,72,73$

Jewish Antiquities (Josephus) 39, see also Josephus

Jewish audience: attempts to convert 6 , 41, 70-72, 76-79, 87-88; for Dialogue 40-41, 45, 50n43

Jewish God 4, 6, 13, 21, 26, 53, 57-58, 63, $82-83,86,88,92 n 57,103,120,139,142$

Jewish Scriptures 4-6, 53, 56, 57,

75,85 ; confirmation of truth of 87 ; contradictions in 57-59; interpretations of 58-59; Jesus and 6, 75-76, 88, 140, 141; Old Testament 3, 53, 64n10, 65n15, $65 \mathrm{n} 16,86,140$

Jewish teachers $80,87,9 \ln 43,143$

Jewish traditions 81-82, 92n55, 103-104, 112

Jews 64n11; Bar Kochba revolt and 81-83, 91n55, 92n57; conversion of 70-71, 141-142; criticism of, in Dialogue 71, 73-74, 77-78; disobedience of the 59; divisions among 100, 106, 109-118; fear of Romans by 79-80; hardheartedness of $47,53,55,64 \mathrm{n} 11$, 65n15, 70-71, 73, 77-79, 81-82, 87, 141; heresies among 8, 96-97, 109-118, 133n106, 143; Justin's tolerance toward 103-105; persecution of Christians by 151-152; reasons for lack of conversion by $76-81,87$; recognition of Jesus by 75-79; rejection of Jesus as Messiah by $76-81,86$; unity of $101,125 \mathrm{n} 36$

Johnson, William A. 49n28

John the Baptist 113

Joly, Robert 28n14

Josephus 100-102

Judaism 8n2; Christianity and 139; Hellenism and 38; Second Temple 101; separation of Christianity from 1-2

Judas the Galilean 113

Justin Martyr 1-2, 3, 7, 8, 28n11, 30n26, $50 \mathrm{n} 47,5 \ln 49,63 \mathrm{n} 4,64 \mathrm{n} 5,64 \mathrm{n} 11$, 65n17, 66n29, 90n31, 91n54, 93n69, 128n71, 133n107, 138n139, 154n20; Acts of the Apostles and 145-154; conversion of 70; First Apology 5, 12n31, 13-23, 26, 139; life of 13; school of 45, 50n46; Syntagma 5, 6, 11n28, 12n31, 24-25, 26; see also Dialogue with Trypho

Kalvesmaki, Joel 128n75

Kenyon, Frederic G. 49n28

King, Karen L. 11n24

Kister, Menahem 134n113

Kippenberg, Hans Gerhard 35n50

Klawans, Jonathan $13 \ln 95,137 \mathrm{n} 128$

Knox, Bernard M.W. 49n28

König, Jason 49n36

Kurtz, Lester R. 127n62

Lampe, Geoffrey W.H. 89n22, 137n130

Lampe, Peter 31n28, 93n73, 118-119, 129

Le Boulluec, Alain 2, 9n6, 28n14, 95, 117, 129n83, 132n105, 13n113, 137n126

libraries 43, 44, 50n38

Lieu, Judith M. 8n3, 9n7, 11n23, 60, 65n16, 66n27, 67n34, 67n38, 67n43, 90n32, 91n53, 92n57, 138n136

Lipsius, R.A. 25, 36n61

Löhr, Winrich A. 65n16

Lotz, John-Paul 138n137

Louis, Pierre 34n 40

Lucian of Samosta 16

Lüdemann, Gerd 36n62, 36n63, 137n132

Luttikhuizen, Gerard P. 135n120

Lyman, J. Rebecca 9n6, 26n4, 126n53

Mach, Michael 89n5

MacLennan, Robert S. 132n99

Magus, Simon $31 n 31$

Maier, Harry O. 138n137

Manns, Frédéric 35n50

Marcionites 4, 63n4, 95, 108-109

Marcion 19-26, 30n26, 31n28, 33n37, $53,57,65 \mathrm{n} 16,67 \mathrm{n} 42,68 \mathrm{n} 48,81$, $91 \mathrm{n} 53,119$

Marcovich, Miroslav 10n12, 10n16, 10n22, 10n26, 27n11, 34n41, 48n22, 66n24, 67n37, 67n38, 74, 88n2, 89n2, $126 \mathrm{n} 58,127 \mathrm{n} 69,128 \mathrm{n} 74$

Markschies, Christoph 36n67, 50n46, 136n121, 138n134

Martin, Dale B. 138n137

Masbothei 133n106 
Mason, Steve 47n10

Massaux, Édouard 153n4

meat consumption, see idol meat

Menander 18-20, 24, 32n35, 116, 117

meristae 110, 113, 128n77

Messiah 5, 6, 75, 76-77

Meyboom, Hajo U. 35n50

Millar, Fergus 27n6

Mills, Kenneth 26n4

minim 110, 111-114, 128n77, 131n96

Minns, Denis 11n27, 27n5, 27n7, 30n26, $33 n 37$

Misiarczyk, Leszek 134n113

Mitchell, Margaret M. viii, 138n137

Moll, Sebastian 27n6, 65n16, 67n34

Mosaic Law 52-56, 65n15, 101, 104, 125n36, 140-141

Moses 58-59, 67n35, 114

Mouritsen, Henrik 46n8

Munier, Charles 10n22, 11n26, 27n6

Nag Hammadi library 8n4, 116

Nautin, Pierre 122n8

New Testament 68n48, 81, 140

Neymeyr, Ulrich 50n46

Nickelsburg, George W.E. 130n88

Nicolaitans 25, 36n63

Niese, Benedikt 47n10

Norelli, Enrico 65n16, 122n7

Numenius 21, 99

O’Brien, Carl Séan 94n74

Old Testament 3, 53, 64n10, 65n15, 65n16, 86,140

Osborn, Eric Francis 26n1

orthodoxy-heresy binary 2, 139

Otranto, Giorgio 130n88

Overbeck, Franz 38, 46n2

pagan hypothesis, for audience of the Dialogue 38-40, 47n12, 92n60

Pagels, Elaine 9n6

Parsons, Mikeal C. 153n4

Parvis, Paul M. 11n27, 27n5, 30n26, 33n37, 92n58

Parvis, Sara 26n2, 27n7, 125n39

Paul 64n5, 75, 77, 100, 111, 119, 130n85

Pearson, Birger A. 133n106

Pervo, Richard I. 128n75, 146, 151, $153 n 2,153 n 4$

Petit, Françoise 124n24

Pétrement, Simone, 36n65

Pharisees 111, 113, 130n93, 133n106
Philo of Alexandria 98, 136n121

philosophy $16,19,83-86,98,102,106$, 108-109, 128n71, 142

Pouderon, Bernard 125n39

Plato 21, 85-86, 99

Platonism 83, 84-86, 93n68, 99, 108-109, 142

Pliny the Elder 98

Pompeius, Marcus 39, 44

Prigent, Pierre 10n21, 48n24, 143

proof-from-prophecy approach 52, 69,

75-78, 86, 87, 106-108, 141

prophecy 52, 69, 75-78, 86, 87, 106-108, $128 \mathrm{n} 73,143,149$

prophets 58-59, 60-61, 83, 84, 93n69, 107

Pythagoreans 99

Quispel, Gilles 128n77

Räisänen, Heikki 64n11

Rajak, Tessa 3, 10n15, 41, 89n14, 153n1

Reed, Annette Yoshiko 8n3

Rehm, Bernhard 122n12

Remus, Harold 88n1

resurrection of the dead 103

Reydams-Schils, Gretchen J. 34n39

Rhodon $3 \ln 28$

Rijksbaron, Albert 134n111

Rokeah, David 48n14, 132n99, 134n110

Roman persecution 18, 23, 79-80, 147, 149, 151-152

Ross, William D. 8n1

Rothschild, Clare K. 124n32

Rousseau, Adelin 136n123

Rowe, C. Kavin 153n4

Royalty, Robert 9n7, 92n58, 119, 138n135

Rudolph, Anette 10n13

Runia, David T. 134n111, 135n115

sacrifices 57, 82, 103

Sadducees 111, 113, 130n88, 130n93, $133 n 106$

Sagnard, François M.M. 122n6

Salles, A. 35n50

Samarians/Samaritans 18, 20, 21, 32n35, 53n126, 133n106

Saturnilians 4, 36n67, 95, 117

Saturninus 116-117, 136n124

Schmeller, Thomas 50n46

Schoedel, William R. 134n113

Schoeps, Hans Joachim 35n50, 128n77

Scholten, Clemens, 32n35

Schremer, Adiel 131n96 
Schubart, Wilhelm 47n9, 49n28

Schwartz, Seth 92n55

Second Temple Judaism 101

Secret Book of John 116

Setzer, Claudia J. $91 \mathrm{n} 45$

Shotwell, Willis A. 132n98

Shuve, Karl 35n50

Simon, Marcel 129n77, 129n84, 134n113

Simon Magus 18-26, 32n31, 32n35, $35 \mathrm{n} 50,116,117$

Skarsaune, Oskar 2, 9n10, 47n12, 67n42, 90n24, 92n60, 93n65, 93n69, 122n6, $153,154 \mathrm{n} 22$

Skeptics 98

Slusser, Michael $11 \mathrm{n} 22$

Smith, Geoffrey S. 9n7, 28n14, 36n62, 36n63, 36n64, 127n64, 131n96

Smith, Jonathan Z. 106, 127n73

Smyth, Herbert Weir 134n111

Snyder, Harlow Gregory 50n38

"so-called" Christians 17-19, 23, 25, 36n66, 96, 102, 106, 109, 117

Socrates 22-23, 99

Stanton, Graham 47n12

Stark, Rodney 90n31

Starr, Raymond 49n29

Steenberg, Matthew C. 35n49

Sterling, Gregory E. 124n32

Stoicism 34n39, 99, 108, 128n71

Strecker, Georg 122n12

Stylianopoulos, Theodore 41, 46n4, 55, 70-71, 76, 87

Swain, Simon 32n31

Syntagma (Justin Martyr) 5, 6, 11n28, 12n31, 24-26, 33n37, 36n57, 36n64, 36n67, 48n24, 67n42, 143

Tacitus $125 \mathrm{n} 36$

Talbert, Charles H. 153n4

Tatian 102, 125n42

Taylor, Joan E. 129n77

Tcherikover, Victor 48n13

Tell, Håkan 123n13

Tertullian 59, 63n4, 65n15, 66n23, 75-76, 78-79, 90n32, 135n119, 140

Thériault, Gaétan 123n16

Thomassen, Einar 127n62, 136n121, $137 \mathrm{n} 130$

Thompson, Alan 98, 123n18

Thorsteinsson, Runar M. 34n38
Trakatellis, Demetrios 90n24

Trelenberg, Jörg 125n42

Tröger, Karl-Wolfgang 68n48

Trypho 47n12, 49n27, 90n24, 92n60,

133n107; companions of 39-40, 47n12; role of 120

Tuckett, Christopher 138n137

Turner, Eric G. 49n28

Turner, John D. 93n68

Tyson, Joseph B. 64n11

Unger, Dominic J. 35n48

unity $97-102,106,122 \mathrm{n} 12,125 \mathrm{n} 36$, 142-143, see also homonoia

Ulrich, Jörg 50n46

Valentinians 4, 24, 36n67, 95, 119

Verheyden, Joseph 9n7

Van Winden, Jacobus C.M. 93n71

Vermaseren, Maarten Jozef 135n1120

Verwijs, Pieter Gotfried 64n11

von Campenhausen, Hans 54, $64 \mathrm{n} 6$

Vööbus, Arthur 123n12

Voss, Bernd Reiner 46n3

Wallraff, Martin 49n28

Wanke, Daniel 37n67

Welborn, Laurence L. 138n137

Wendel, Susan J. 153n1

Wevers, John William 136n122

White, Peter 46n9

Whittaker, John 10n11, 34n39

Wilhite, David E. 68n48

Wilken, Robert L. 134n113

Williams, A. Lukyn 130n86

Williams, Michael Allen 11n24, 24n11

Wilson, Robin McL. 135n115

Wilson, Stephen G. 48n21, 64n11, 88n1, 89n6, 90n24, 90n31, 92n57

Winsbury, Rex 49n32

Wisse, Frederick 68n48

Young, Frances M. 92n58

Youtie, Herbert C. 153n7

Zahn, Theodor 46n2, 47n12

Zellentin, Holger M. 9n7, 117, 137n127

Zito, George V. 127n62

Zugmann, Michael 130n84 